\title{
The economics of auditor careers and audit markets
}

Citation for published version (APA):

Meuwissen, R. H. G. (1999). The economics of auditor careers and audit markets. [Doctoral Thesis, Maastricht University]. Datawyse / Universitaire Pers Maastricht. https://doi.org/10.26481/dis.19990917rm

Document status and date:

Published: 01/01/1999

DOI:

10.26481/dis.19990917rm

Document Version:

Publisher's PDF, also known as Version of record

\section{Please check the document version of this publication:}

- A submitted manuscript is the version of the article upon submission and before peer-review. There can be important differences between the submitted version and the official published version of record.

People interested in the research are advised to contact the author for the final version of the publication, or visit the DOI to the publisher's website.

- The final author version and the galley proof are versions of the publication after peer review.

- The final published version features the final layout of the paper including the volume, issue and page numbers.

Link to publication

\footnotetext{
General rights rights.

- You may freely distribute the URL identifying the publication in the public portal. please follow below link for the End User Agreement:

www.umlib.nl/taverne-license

Take down policy

If you believe that this document breaches copyright please contact us at:

repository@maastrichtuniversity.nl

providing details and we will investigate your claim.
}

Copyright and moral rights for the publications made accessible in the public portal are retained by the authors and/or other copyright owners and it is a condition of accessing publications that users recognise and abide by the legal requirements associated with these

- Users may download and print one copy of any publication from the public portal for the purpose of private study or research.

- You may not further distribute the material or use it for any profit-making activity or commercial gain

If the publication is distributed under the terms of Article $25 \mathrm{fa}$ of the Dutch Copyright Act, indicated by the "Taverne" license above, 


\section{The economics of}

auditor careers and audit markets 
(C) R.H.G. Meuwissen, Maastricht 1999 ISBN 9052782512

Druk: Universitaire Pers Maastricht 


\section{The economics of}

\section{auditor careers and audit markets}

\section{PROEFSCHRIFT}

ter verkrijging van de graad van doctor aan de Universiteit Maastricht, op gezag van de Rector Magnificus, Prof. Dr. A.C. Nieuwenhuijzen Kruseman, volgens het besluit van het College van Decanen, in het openbaar te verdedigen op vrijdag 17 september 1999 om 16.00 uur

door

Roger Henry Gerhard Meuwissen

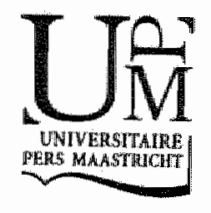


Promotores:

Prof. Dr. W.F.J. Buijink

Prof. Dr. S.J. Maijoor

Beoordelingscommissie:

Prof. Dr. J.A.M. Heijke (voorzitter)

Prof. Dr. R.J.M. Dassen RA

Prof. Dr. M. Jegers (Vrije Universiteit Brussel, België) 


\section{Acknowledgements}

The preparation of a dissertation is not always easy. I can't remember working as hard as I did in the last year. However, I wouldn't have managed without the help and encouragement of others.

I thank my supervisors Willem Buijink and Steven Maijoor. Willem Buijink introduced me to research when he hired me as a research assistant. Steven Maijoor became my first 'employer' when I started as a researcher at the Maastricht Accounting and Auditing Research and Education Center. Thank you both for your enthusiasm, your valuable suggestions and helpful comments. This dissertation draws to a large extent on our discussions, which appeared to be most fruitful in airport lounges and in 'de Tribunal'. Thanks also to Roger Dassen, Hans Heijke and Marc Jegers for judging the final version of the manuscript and for providing useful comments.

Since the studies in this dissertation are based on large amounts of data, the devoted labours of my research assistants over the years, Ralph Voncken, Markus Schaen, Egon Houben, Joyce Nelissen, Ivette Hennen and Jan Franssen were of immeasurable help.

An essential ingredient in the writing of a dissertation is the environment in which the effort takes place. Therefore, I would like to thank my colleagues for providing such an environment, and also for their comments and support, especially Els van Aernsbergen, Rogier Deumes, Rob Eken, Gerard van Gogh, Harold Hassink, Boudewijn Janssen, Martien Lubberink, Frank Moers, Ton van Reeken, Caren Schelleman, Philip Vergauwen, Mark Vluggen and Frans Volmer. Thanks also to my former colleagues Bram Beek, Jos Blommaert, Marc Gulikers, Frank Hartmann, Gerard Mertens, Eddy Vaassen and Maurice Zinken. Apparently, mobility even applies to academics. Special thanks to Laury Bollen and Luc Quadackers for their comments and encouragements, but also for their help when 1 could not catch up with new software developments. And there were many.

Finally, I thank my family for their support, but most of all, I thank Esther. "Behind every ... man there has got to be a great woman." 



\section{Contents}

Page

\section{Chapter 1 Introduction}

1.1 Auditor careers and audit markets $\ldots \ldots \ldots \ldots \ldots \ldots \ldots \ldots$

1.2 The economics of auditing: background and some examples . . . . . 12

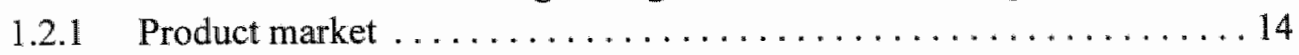

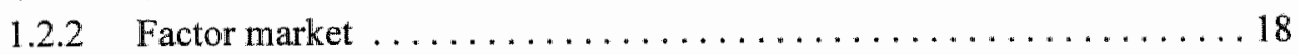

1.3 The economics of auditor careers and audit markets ........... 18

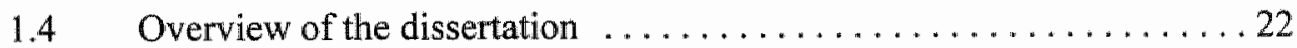

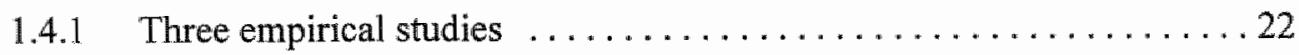

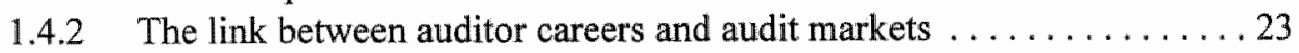

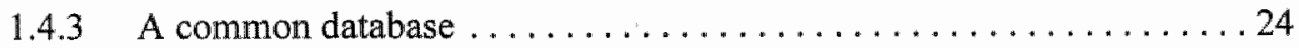

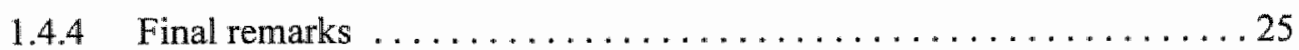

\section{Chapter 2 Career advancement in audit firms}

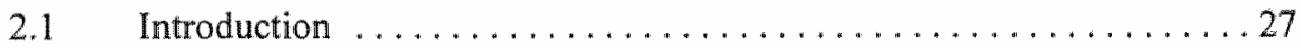

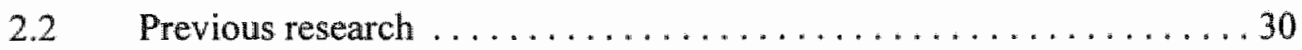

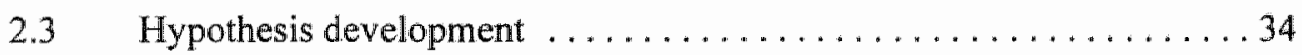

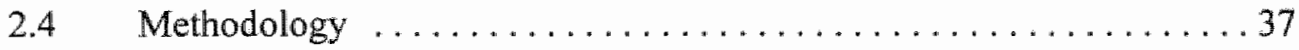

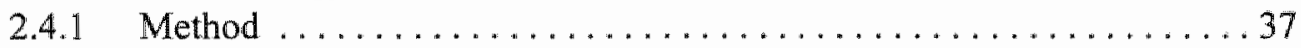

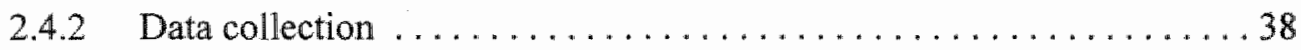

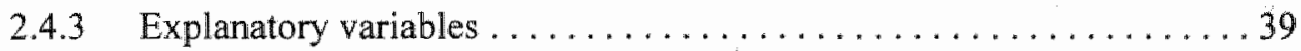

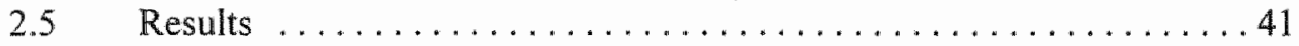

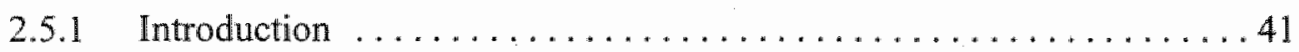

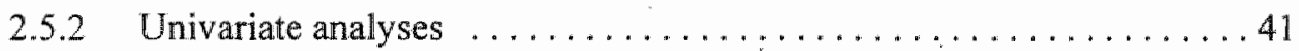

2.5.3 Multivariate analyses ........................ 47

2.5.4 Career advancement in Big Six audit firms ............... 54

2.5.5 Auditors who did not advance to partnership ............. 56

2.6 Concluding remarks ............................. 57 


\section{Chapter 3 Inter-organizational auditor mobility}

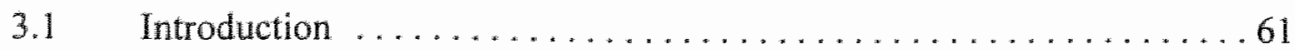

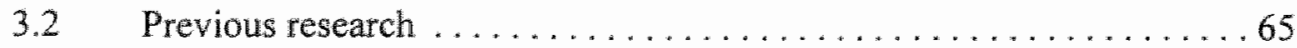

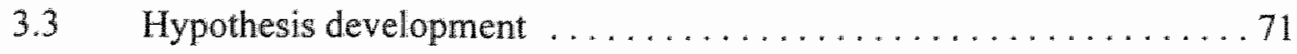

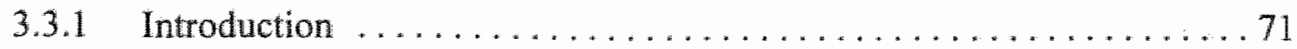

3.3.2 A general model of inter-organizational auditor mobility $\ldots \ldots \ldots \ldots 71$

3.3.2. Audit firm size and inter-organizational auditor mobility . . . . . . . 71

3.3.2.2 Personal variables and inter-organizational auditor mobility . . . . . 75

3.3.2.3 The timing of inter-organizational auditor mobility . . . . . . . . 78

3.3.3 Specific tests of inter-organizational auditor mobility $\ldots \ldots \ldots \ldots 79$

3.3.3.1 Up-or-out promotion systems and inter-organizational

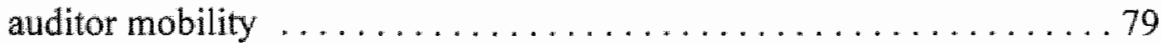

3.3.3.2 Audit quality and inter-organizational auditor mobility . . . . . . . . 80

3.3.3.3 Client-specific investments and inter-organizational auditor mobility $\ldots 81$

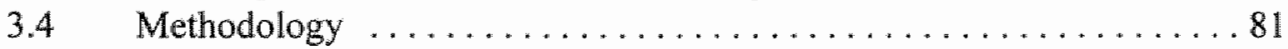

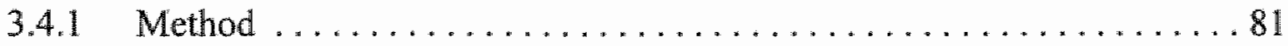

3.4 .2 Data collection ............................... 82

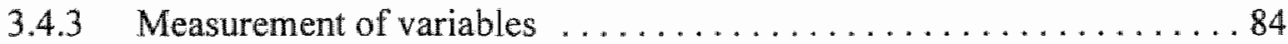

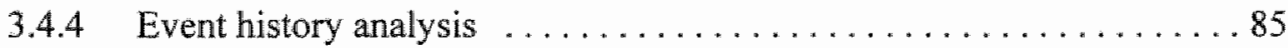

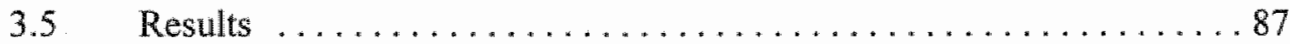

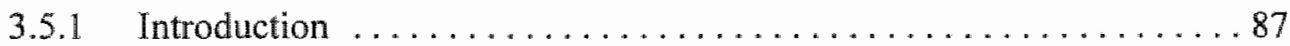

3.5.2 Descriptive statistics on inter-organizational auditor mobility . . . . .87

3.5.3 A model of total inter-organizational auditor mobility .......... 90

3.5.4 Up-or-out promotion systems and inter-organizational

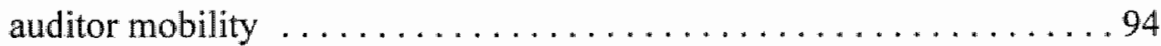

3.5.5 Audit quality and inter-organizational auditor mobility . . . . . . 997

3.5.6 Client-specific investments and inter-organizational auditor mobility .102

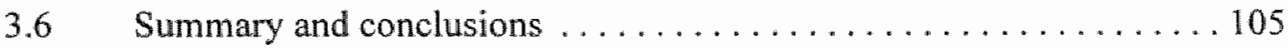

\section{Chapter 4 Competition in audit markets}

4.1 Introduction . . . . . . . . . . . . . . . . . . . . . . . . . . . 109

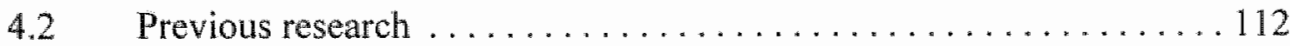

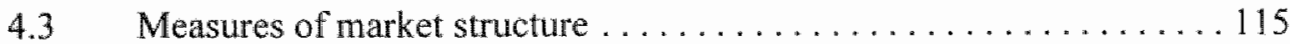

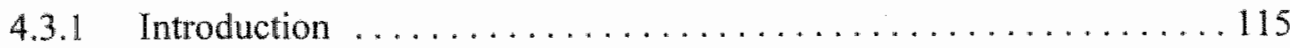

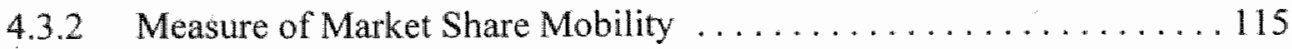

4.3 .3 Measures of Entry and Exit ................... 116

4.3.4 Static measures: the Concentration Ratio $\mathrm{C}_{\mathrm{B}}$ and the Hirschman-Herfindahl Index . . . . . . . . . . . . . 117

4.4 Regulation and competition in the Belgian, German and

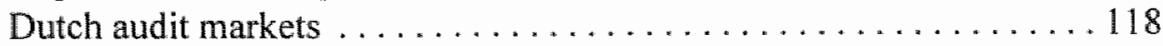

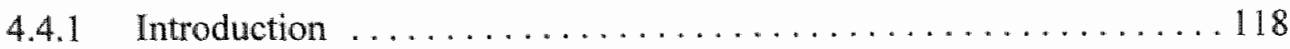

4.4 .2 Professional entry requirements . . . . . . . . . . . . . 119 


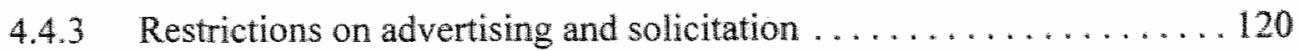

4.4.4 Restrictions on auditor services . . . . . . . . . . . . . . . 120

4.4.5 Conclusions on the regulatory regimes $\ldots \ldots \ldots \ldots \ldots \ldots \ldots \ldots 121$

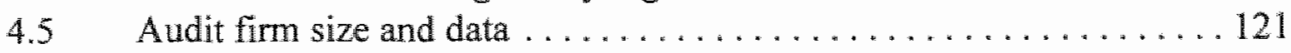

4.5 .1 Audit firm size ............................ 121

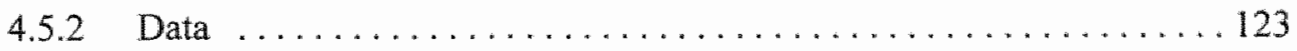

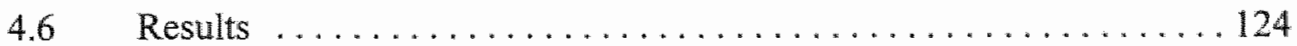

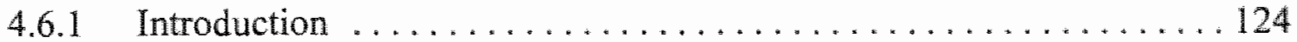

4.6.2 Descriptive results . . . . . . . . . . . . . . . . . . 125

4.6.3 Results for the static market structure measures . . . . . . . . . . . 129

4.6.4 Results for the dynamic market structure measures $\ldots \ldots \ldots \ldots 131$

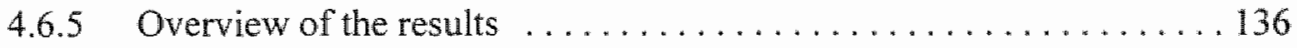

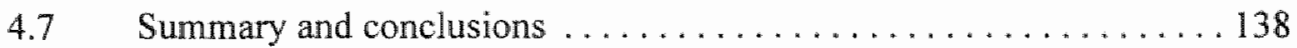

Appendix A An analysis of the regulatory regimes of the auditing professions in Belgium, Germany and the Netherlands . . . 140

A.1 Introduction .......................... 140

A.2 Audit market regulation in Belgium .............. 140

A.2.1 Overview of the Belgian auditing profession $\ldots \ldots \ldots \ldots 140$

A.2.2 Audit market regulation ................... 142

A.3 Audit market regulation in Germany .............. 145

A.3.1 Overview of the German auditing profession $\ldots \ldots \ldots \ldots 145$

A.3.2 Audit market regulation ..................... 146

A.4 Audit market regulation in the Netherlands . . . . . . . . . . 148

A.4.1 Overview of the Dutch auditing profession $\ldots \ldots \ldots \ldots \ldots 148$

A.4.2 Audit market regulation .................... 150

A.5 The effects of regulation on audit markets $\ldots \ldots \ldots \ldots \ldots 152$

Appendix B Procedures used in compiling the data ............. 156

\section{Chapter 5 Summary and discussion}

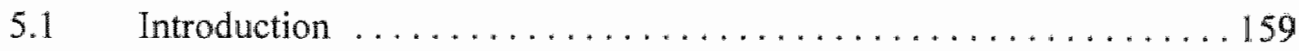

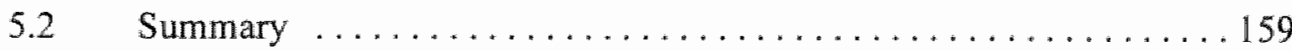

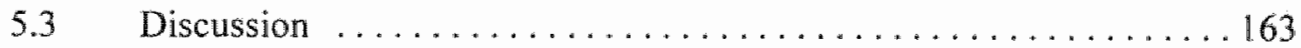

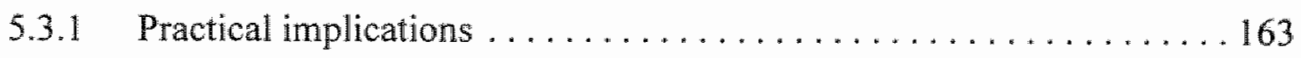

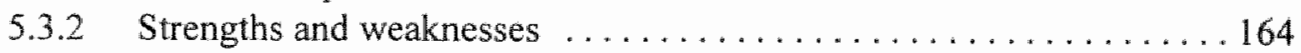

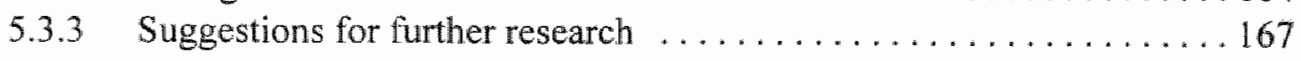

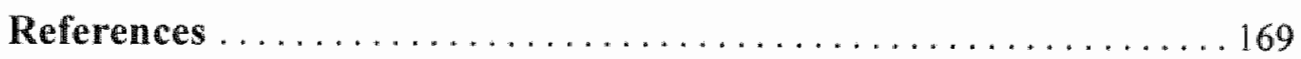

Summary in Dutch (Nederlandse samenvatting) $\ldots \ldots \ldots \ldots \ldots$

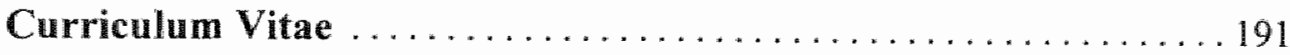





\section{Chapter 1 Introduction}

\subsection{Auditor careers and audit markets}

This dissertation examines the economics of auditor careers and audit markets. The economics of auditor careers is addressed by a study on factors affecting the career advancement of auditors within audit firms as well as by an analysis of inter-organizational auditor mobility. The economics of audit markets is addressed by a study of audit market structure in three audit markets.

The purpose of this research is twofold. With respect to auditor careers, the dissertation aims at contributing to the empirical literature on auditing by approaching audit firms as collections of individuals, instead of as single entities. This contrasts with previous auditing research, which viewed audit firms as single entities when addressing research issues such as the effects of client-specific investments and audit quality differences. Research into individual careers provides insights into the functioning of audit firms, and enables the examination of auditing phenomena from a different perspective, that of the individual auditor. With respect to audit markets, this dissertation aims to contribute to the assessment of competition in audit markets by means of a dynamic analysis of audit market structure. In contrast to a static seller concentration analysis, a dynamic analysis provides a better understanding of the competitive forces in audit markets and consequently of the functioning of those markets.

To further position this dissertation, section 1.2 presents an overview of economics based empirical auditing research. After that, section 1.3 discusses the economics of auditor careers and audit markets in particular. Motivation is provided for selecting an economic approach to study auditor careers and audit markets. Finally, section 1.4 contains a brief outline of the remainder of this dissertation and discusses the links between the studies on auditor careers and audit markets, and the data used in this dissertation. 


\subsection{The economics of auditing: background and some examples}

There are many ways in which auditing can be studied. From the previous literature on auditing, the two most prominent research perspectives appear to be psychology and economics. Examples of auditing studies from a psychological perspective are auditor judgement studies [see, e.g. Mock and Turner (1981); Biggs and Wild (1985); Ashton (1991)], and most studies on individual behaviour in audit firms [see, e.g. Jiambalvo (1979); Norris and Niebuhr (1983); Bullen and Flamholtz (1985); and for an overview Dillard and Ferris (1989)].

This dissertation applies an economics framework to study auditing. Using economics as a research framework implies that auditors and audit firms are assumed to take actions that are in their best interest [see Lazear (1998)]. Within this framework, the two primary research approaches are analytical and empirical. To further position the current research, this dissertation contributes to the empirical part of the economics based auditing literature.

When studying the economics of auditing, it is essential to acknowledge a dominant characteristic of audit firms: the importance of human capital. Audits of audit firm clients are performed by individual auditors and so the actual capacity to perform audits rests with the auditors and not with the firm. In other words, an audit firm's capacity to render audit services is actually the combined human capital of its individual auditors [see Gilson and Mnookin (1985)]. Furthermore, if auditors decide to leave an audit firm they remove a part of that firm's capital, affecting its competitive position. This occurs not only because the audit firm loses parts of its audit capacity, but more importantly because auditors who leave their current firm can easily found their own firm. Hence, in that case they become a competitor of their former firm. Accordingly, the dynamics observed in audit markets can actually be partly seen as the result of individual career decisions. In other words, in audit firms, and similar to law firms and consulting firms, there is a close link between the product market, where audit firms supply audit services to clients, and the factor market, where audit firms demand human capital inputs [see Gilson and Mnookin (1985)].

The interaction between the product market and the factor market in auditing is used to provide a framework for organizing previous research on the economics of auditing. FIGURE 1 presents the two areas of research that can be distinguished: auditing research with respect to the product market and auditing research with respect to the factor market. The discussion starts from the clients' box since they initiate the demand for audit services. Auditing supply will then be forthcoming, and will create demand for and supply of auditors, as can be seen in FIGURE 1. 
FIGURE 1

Research framework for the economics of auditing

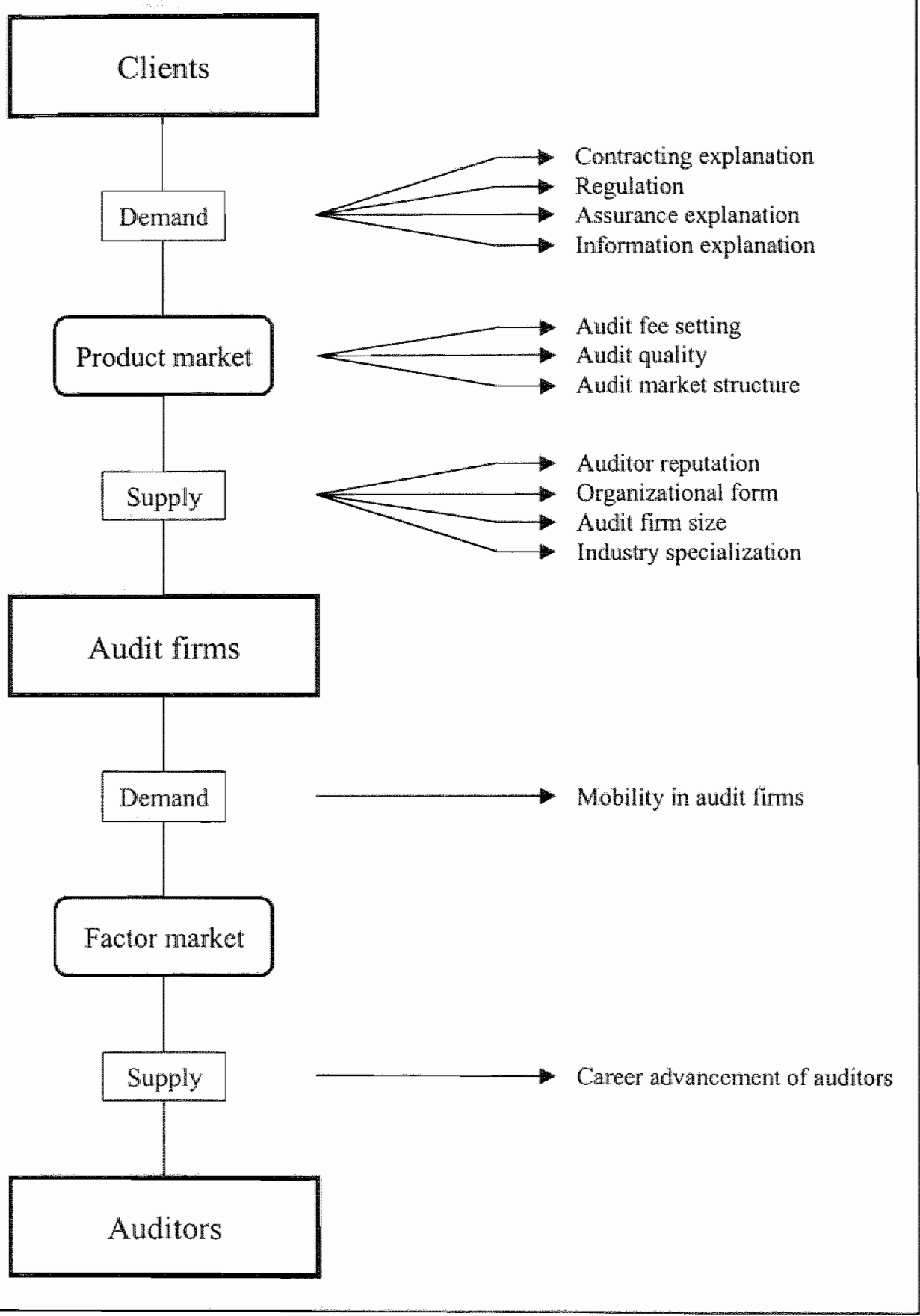




\subsubsection{Product market}

A broad field of auditing research has emerged on the product market. This research relates to demand and supply issues as well as to competition on the product market itself. For each of these research areas, the most prominent research themes are listed on the right hand side of FIGURE 1. First, the demand for audit services will be discussed, followed by research on the supply of audit services. After that, research on competition on the product market will be addressed."

\section{Demand for audit services}

Several explanations can be advanced for the demand for audit services. Much of the previous research, however, has been driven by economics-based contracting theory [see Jensen and Meckling (1976); Watts and Zimmerman (1986)]. The contracting framework is used by Chow (1982) to investigate the voluntary demand for audit services. He concluded that the existence of an independent audit is associated with debt contracts. A more recent study by Buijink (1992) extended Chow (1982) by investigating the demand for audit services in a Dutch environment, obtaining similar results. Further evidence regarding the economic role of voluntary audits in contracts is provided by Watts and Zimmerman (1983). The contracting framework has also been used to explain the choice of auditor. Eichenseher and Shields (1985) and DeFond (1992), for example, show that auditor choice can be explained by client characteristics relating to agency costs. That is, the higher the auditee's debt-to-asset ratio, the more likely the selection of a large audit firm.

Other explanations for the demand for audit services relate to regulation, the information hypothesis, and the insurance hypothesis [see Benston (1985); Wallace (1987, 1991); and Abdel-Khalik and Solomon (1988)]. Severall studies have addressed the economics of audit regulation by examining the effects of regulation on the demand for audit services [see, e.g. Maijoor and van Witteloostuijn (1996)], or by comparing the influences of different regulatory regimes [see, e.g. European Commission (1996)]. The economic consequences of regulation have also been addressed by studies on, for example, auditor changes [see, e.g. DeAngelo (1982)]. Overall, these studies conclude that there are pervasive economic effects of regulation on the functioning of audit markets.

1 Note that, as already mentioned, this overview focuses on economics-based empirical research studies. Furthermore, this overview does not attempt to be exhaustive, but provides some examples of studies undertaken on the research themes identified. 
The information hypothesis implies that shareholders demand audited financial information to make investment decisions. In this regard, it is argued that through audit firm selection, businesses can signal their superior performance to investors. Beatty (1989) analysed the effect of auditor choice on the price of initial public offerings (IPOs) and found that the price of IPOs increased with the selection of a large audit firm. Furthermore, evidence is also provided that growing and less risky auditees tend to select large audit firms [see, e.g. Simunic and Stein (1987); Francis and Wilson (1988); DeFond (1992)]. Hence, consistent evidence is provided that the choice of audit firm is associated with client performance.

Another line of research uses the insurance perspective to explain the demand for audit services. This area of research is based on the premise that providers of external capital demand audits to insure against losses from business failure, because audit firms are thought to have 'deep pockets' as compared to bankrupt businesses. The insurance hypothesis has started a stream of research on factors associated with litigation. Evidence of attempts to litigate is provided by, for example, St.Pierre and Anderson (1984) and Palmrose (1987). St.Pierte and Anderson (1984) found that public companies as well as newer clients are more likely to undertake legal action against the audit firm when negative financial information is disclosed, even when no audit failure occurred. Palmrose (1987) provides evidence that business failures and management fraud are associated with auditor litigation.

\section{Supply of audit services}

Similar to explaining the demand for audit services, contracting theory is also used to explain the most dominant supply issues in the product market. According to Watts and Zimmerman (1986), the most prominent research issues are auditor reputation, organizational form of audit firms, audit firm size and industry specialization.

Auditors add credibility to financial information. However, the quality of audits is costly to evaluate [DeAngelo (1981a)]. Therefore, clients need to rely on the auditor's reputation. From an economics perspective, reputation will increase both the demand for audit services and the audit fee. Several studies have found fee premiums associated with auditor reputation [see, e.g. Beatty (1989); Menon and Williams (1991); Craswell, Francis and Taylor (1995)].

The organizational form of audit firms is an interesting, but still fairly underdeveloped, area of study. According to Fama and Jensen (1983) the organizational form of audit firms serves as a bonding mechanism between auditors and shareholders. Liability exposure in unlimited partnerships encourages 
auditors to be independent. Furthermore, unlimited liability also induces mutual monitoring by the partners because each partner is liable for the other partners" actions. Another issue in partnerships are the profit-sharing arrangements. Holmes and Zimmer (1998) found that the organizational form influences the profitsharing arrangements in audit firms.

The existence of large audit firms can partly be explained by economies of scale. If large audit firms benefit from economies of scale, they will show superior audit efficiency leading to lower audit fees or higher profits. To test for economies of scale, studies either focussed on audit fees and audit effort [see, e.g. Simunic (1980); Palmrose (1986); O'Keefe, Simunic and Stein (1994)], or on industry specialization [see, e.g. Eichenseher and Danos (1981); Danos and Eichenseher (1982); Craswell and Taylor (1991)]. Overall, the audit fee studies conclude that large audit firms obtain cost advantages through economies of scale, but also receive fee premiums probably owing to product differentiation. Research on industry specialization examines whether specialized knowledge results in economies of scale for audit services provided in particular industries or market segments. In general, these studies conclude that audit firms obtain economies of scale in regulated industries, in large client segments of other industries and in the market for IPOs.

\section{Competition on the market for audit services}

With respect to the interaction between demand and supply on the market for audit services, empirical auditing research has evolved along the following three themes: audit fee setting, audit quality and audit market structure. In general, these three themes are studied in the context of competition in the audit market. Since the seminal study by Simunic (1980) on the pricing of audit services, there has been considerable interest in explaining the economics of audit fees. Several studies extended Simunic's model of audit pricing by addressing additional variables or other audit markets [see, e.g. Francis (1984); Firth (1985); Simon (1985); Chung and Lindsay (1988)]. These studies generally support the notion that large firms earn higher audit fees than smaller firms, but that the audit market is competitive. Furthermore, several studies have addressed specific issues related to the economics of audit fees. Evidence is provided of price cutting in the first years of initial audit engagements [see, e.g. Simon and Francis (1988); Ettredge and Greenberg (1990); Turpen (1990)], voluntary auditor changes because of competition among audit firms [Johnson and Lys (1990)], effects of knowledge spillovers between audit services and other services on audit fees [see, e.g. Simunic (1984); O'Keefe, Simunic and Stein (1994)], and the effect of litigation risk on audit fees [Beatty (1993); Simunic and Stein (1996)]. 
Another research theme on the interaction between demand and supply of audit services relates to the quality of audit firms. DeAngelo (1981b) argued that larger audit firms have fewer incentives to behave opportunistically to ensure retention of clients and thus provide higher quality audits as compared to smaller audit firms. Various empirical studies have addressed the alleged quality difference between large and small audit firms. Palmrose (1988) concluded that large audit firms have lower litigation rates than small firms by comparing litigation records of large and small audit firms. This is consistent with DeAngelo"s (1981b) suggestion that larger audit firms provide higher audit quality. Other studies have demonstrated quality differences between large and small audit firms by examining, for example, the relationship between management earnings forecasts and audited, reported earnings [Davidson and $\mathrm{Neu}$ (1993)], by analysing stock market reactions of companies changing to smaller audit firms [Eichenseher, Hagigi and Shields (1989)], or by examining review findings in audit files to measure the actual detection of errors [Deis and Giroux (1992)]. Overall, consistent evidence is provided that larger firms provide higherquality audits.

Numerous papers have appeared on the market structure for auditing. The perceived dominance of the auditing profession by the largest audit firms provides a frequent focus of attention to regulators and to researchers. Mautz and Sharaf (1961) were the first to notice this phenomenon. The first empirical study on audit market concentration was performed by Zeff and Fossum (1967). They described market shares of audit firms based on size figures of firm clients listed in The Fortune Directory 1965. Zeff and Fossum (1967) found that the Big Eight audit firms dominated the market although the extent of domination varied across industries. And as Zeff and Fossum (1967, p. 306) stated: "The data presented in this study barely scratch the surface of a potentially fascinating area of study, namely, how public accounting firms grow, develop, and acquire personalities.", their pioneering study was followed by many other audit market structure studies. These studies, however, focussed on static measures of market structure [see, e.g. Gilling and Stanton (1978); Tomczyck and Read (1989); and Pearson and Trompeter (1994)], whereas studies in industrial economics show that dynamic measures are better indicators of the competitive processes in markets 【see, e.g. Baldwin and Gorecki (1989)]. A comprehensive overview of related audit market research will be presented in chapter 4 . 


\subsubsection{Factor market}

\section{Demand, supply and competition on the factor market}

After exploring the broad field of economic auditing studies with respect to the product market, factor market research will now be discussed. Although many studies have addressed auditor judgement and auditor behaviour, these studies primarily used a psychological perspective [see, e.g. Bullen and Flamholtz (1985) Dillard and Ferris (1989); Reed, Kratchman and Strawser (1994)]. Only a handful of empirical auditing studies examined the factor market from an economics viewpoint. Two studies addressed the demand for auditors in the factor market. Waller (1985) used a contracting approach to study auditor mobility in audit firms. By examining self-selection of employment contracts Waller (1985) was able to identify employees in terms of their propensity to leave the audit firm within a short period of time. Dalton, Hill and Ramsay (1997b) analysed the threat of litigation as a major source of mobility in audit firms, and found that partners are more likely to leave the audit firm in a litigious environment. Research on auditor mobility will be discussed in-depth in chapter 3 .

Research with respect to the supply side of the factor market primarily consists of studies on the career advancement of auditors [see, e.g. Siegel (1987); Wright (1988); Bhamornsiri and Guinn (1991)]. These studies, however, merely address factors associated with auditor career advancement, and do not provide forthright economic explanations for their findings. This area of research will be more extensively discussed in chapter 2 .

\subsection{The economics of anditor careers and audit markets}

From the overview of the economics-based empirical auditing literature, it can be concluded that research primarily has focussed on the product market. Research on the factor market is less developed. This section demonstrates how auditor careers can be examined from an economics perspective. Examples are given on how to study the economics of auditor careers. Furthermore, although the product market has been extensively studied, an example will be given on how research on audit market structure can be extended. Such research automatically implies an economics perspective. However, first an explanation will be given on using economics as a research framework.

In this thesis, economics forms the basis to study auditor careers and audit markets. As Lazear (1998) argues, this does not imply that human factors, which 
are important in professional service firms, are ignored. Using economics as a research framework only implies that auditors and audit firms are supposed to act in their best interest. Furthermore, the economics approach assumes that tastes are stable over time so that behaviour can be predicted, founded on the assumption that auditors and audit firms continually try to achieve their objectives [see Lazear (1998)].

Both careers and markets are associated with economic decisions. With respect to the factor market, auditors encounter several economic decisions in their career, such as the choice of education, the choice of employer, and associated with this latter choice, the probability of promotion. Audit firms need to make economic decisions with respect to, for example, investments in human capital. The economics in these decisions will be sketched out below. After that, an example will be given on the economics of the product market, more specifically, on the economics of audit market structure.

\section{Education}

The choice of education is an economic decision that relates to human capital theory [see, e.g. Becker (1964)]. Human capital theory pertains to the acquisition of skills. According to Lazear (1998, p. 135), the two most important ways to acquire human capital are formal schooling and on-the-job training. For the current discussion, however, only schooling is relevant.

Individuals invest in human capital through formal schooling or education. In doing so, they compare the costs of education with the expected future benefits of education. The cost of education has two components: direct costs, including for example tuition and books, and opportunity cost, specified as the forgone earnings when going to school. The expected future benefits can be defined as additional future earnings. Applying this to audit education, individuals who want to become an auditor have to decide whether to take the experience route or take the university route. ${ }^{2}$ University-educated auditors defer revenues by taking additional full-time education instead of going through the experience route, which would yield them immediate returns. These deferred revenues would have to be recovered by university-educated auditors in later career stages.

\section{Employer}

The economic theory of human capital also provides a useful framework for evaluating the auditor's choice of employer. Audit firms might differ in career options, which result from differences in human capital acquisition. As stated

\footnotetext{
2 See chapter 2 for an elaboration of these two types of audit education.
} 
before, the two most important ways to acquire human capital are formal schooling and on-the-job training. In this regard, only on-the-job training is relevant. Two types of on-the-job training can be distinguished: general on-the-job training and firm-specific on-the-job training [see Lazear (1998)]. General on-thejob training is an investment in human capital which raises productivity in the current firm as well as in other firms. Firm-specific on-the-job training is an investment in human capital which raises productivity in the current firm, but not in other firms. Furthermore, it is assumed that when productivity raises, earnings will rise too. Employees having received general on-the-job training are able to take the benefits of their higher productivity at the current firm or at other firms. In contrast, individuals with firm-specific on-the-job training are only able to convert their higher productivity to higher earnings at the current firm. Therefore, it can be argued that with general on-the-job training employees bear the full costs of the training but also receive the full benefits of the higher productivity and that with firm-specific on-the-job training the employee and the firm share the costs and the benefits [see Lazear (1998, pp. 143-155)]. Hence, with equal costs and benefit patterns, employees would prefer general on-the-job training.

Applying this to auditing, it can be argued that if audit firms vary with respect to on-the-job training but have equal productivity, auditors will prefer those firms with more general on-the-job training. Another implication would be that auditors having received firm-specific on-the-job training are less likely to change audit firm since they are not able to earn a comparable wage in another firm.

\section{Promotion to partnership}

Auditors enter career tracks in audit firms. Eventually, such career tracks should lead to the attainment of partner positions. Similar to the choice of education and employer, the decision to engage in a partner track is an economic decision. Expected earnings will be compared between different types of partnership. Promotion probability and promotion velocity determine whether and how fast auditors will attain partnership. With information on the earnings as an associate and the earnings as a partner, auditors will assess the expected earnings of partnership. From an economics perspective, differences in promotion probability, promotion velocity, and partner earnings between audit firms will be compared to determine the preferred partner track. Such a decision might lead to conclude not to attain partnership with their current firm but with another audit firm. Ultimately, auditors might decide to start their own audit firm and become solepractitioners. 


\section{Human capital investments}

Audit firms invest in human capital to enhance the productivity of their auditors. Such investments can be viewed from an economics perspective by comparing the costs of human capital investments with the benefits of higher auditor productivity. Since human capital is the most important production factor in auditing, the productivity of auditors influences the competitive position of audit firms, and thus the market for audit services.

Audit firms might decide to create trainee programmes for entry-level auditors to enhance their productivity. Usually, the firm will bear the training costs and trainees will accept lower wages to compensate the firm for the training cost. Of course, wages are adjusted when productivity increases. Alternatively, audit firms might decide to hire senior auditors through lateral entry. The firm bears no training costs but is forced to pay relatively high wages for auditors with less firm-specific capital. Audit firms will choose the most favourable option.

Another example of human capital investments which can be analysed from an economics perspective is the up-or-out promotion system [see Gilson and Mnookin (1989)]. During an apprenticeship period, audit firms invest in auditors' human capital to enhance their productivity. However, although associate auditors are productive at the associate level and are a source of income of the audit firm, when they do not meet the criteria for partnership they will have to leave the firm. In this respect, audit firms deliberately lose valuable resources by not retaining the associate auditor. Nevertheless, Gilson and Mnookin (1989) argue that the up-orout system serves as a bonding mechanism assuring a fair evaluation of associates. The audit firm is forced to make a (positive or negative) partnership decision and cannot behave opportunistically denying auditors to progress to partnership and keep them as associates. Furthermore, it provides the audit firm with the opportunity to hire new and perhaps more productive entry-level auditors in a partner track position.

\section{A udit market structure}

Like auditors, audit firms are also faced by a large number of economic decisions to be made. For example, audit firms will compare the benefits of rendering audit services to certain clients with the costs associated with those efforts. The direct benefit of supplying audit services is the audit fee, and indirect benefits are increases of client goodwill by providing the desired level of service. Direct costs of audits include the input of human capital, and indirect costs are for example insurance fees against potential claims. Such decisions can be made for each level of audit quality. A higher level of audit quality implies a higher audit fee, but also higher costs because of a higher audit effort. 
With respect to the provision of audit services, audit firms have to decide the size of their operations. Audit firms might decide to grow bigger, either by internal growth or taking over other firms, and dominate (parts of) the audit market, whereas others remain small and try to serve niches in the audit market. Industrial economics is concerned with the size distribution of market participants to observe the competitiveness of markets. In this respect, the market power of audit firms is determined by their market shares, and when output is concentrated in the hands of a very few audit firms, it is posited that these firms have a reduced willingness to compete heavily along the price dimension. Hence, industrial economics is a useful framework for examining competition in the market for audit services.

Above, some examples were given on the economics of auditor careers and audit markets. The study on the career advancement of auditors addresses the economics of auditor careers by examining the economic choices of education and partnership. The economics of auditor careers is also addressed by the study on the inter-organizational mobility, which analyses the economic choice of employer, and to a lesser extent the consequences of up-or-out systems. Of course, both studies have implications for human capital investment by audit firms. The study on audit market structure applies to the example on the supply of audit services. Audit markets are studied from an industrial economics perspective, which implicitly incorporates an economic approach to audit markets.

\subsection{Overview of the dissertation}

\subsubsection{Three empirical studies}

This dissertation contributes to auditing research by investigating the economics of auditor careers and audit markets. The economics of auditor careers is addressed by two studies. First, the career advancement of auditors will be examined. Then a study of the inter-organizational mobility of auditors will be presented. The economics of audit markets is addressed by an analysis of market structure of three audit markets. All three studies are briefly discussed below.

A study on career advancement is undertaken to assess the influence of several variables on the advancement to partnership in audit firms. Career advancement is measured in terms of promotion to partner and promotion velocity. Education, age at qualification, audit firm size and change of audit firm are used to explain differences in career advancement. A central question in this 
respect will be whether the education of auditors needs to be academicallyoriented or practically-oriented, since the Netherlands provides a unique setting to test differences between university and non-university education.

Furthermore, an analysis of inter-organizational auditor mobility is presented. By using organizational variables to distinguish between types of moves, this study addresses client-specific investments and audit quality from a mobility perspective. Variations in client-specific investments and audit quality are used to explain differences in the mobility rates between auditors of different types of audit firms. In addition, the influence of personal as well as organizational variables on the timing and the nature of inter-organizational auditor mobility is examined with event history analysis. This statistical technique is particularly suited to analyse longitudinal mobility data since it enables to study the timing of inter-organizational moves and accounts for time-varying explanatory variables.

Finally, seller concentration, market share mobility and regulation are analysed for the Belgian, German and Dutch audit markets. This part provides a static and dynamic empirical analysis of the structure of the Belgian, German and Dutch audit markets. In addition, the regulatory regimes of these three countries are analysed. The aim is on explaining differences in audit market structure between Belgium, Germany and the Netherlands as a result of their regulatory regimes. Results are presented for audit firm entry and exit, and market share mobility.

\subsubsection{The link between auditor careers and audit markets}

The research issues in this dissertation (i.e. career advancement of auditors, interorganizational auditor mobility, and audit market structure) are considered to be related studies. Attempts have been made to explicate the relationships between auditor careers and audit markets. Not only are all issues investigated from an economics perspective. As auditing is a professional service, careers and markets are closely related.

The market for audit services is affected by decisions of individual auditors. Individual careers, which affect mobility statistics, ultimately determine the competition in audit markets. By making individual career decisions, auditors might leave their current audit firms and found their own firms to become a competitor of their former firm. In this way, audit capacity is regarded as an individual asset and the audit capacity of audit firms consists of the combined capacity of its individual auditors. Hence, the dynamics observed in the audit 
market are actually the result of career advancement and inter-organizational mobility of individual auditors.

Furthermore, all three studies use longitudinal data derived from membership lists of professional bodies of auditors. The period of study for the three studies starts in 1970 and stretches to 1994 (audit market structure) or 1998 (career advancement and auditor mobility). Therefore, an overview of the factor and product markets is provided over the same time-period and with the same type of data. Because of the importance of this common database for the three studies, the next paragraph provides a short introduction to the data used.

\subsubsection{A common database}

As stated in the previous paragraph, all three studies of this dissertation use longitudinal data derived from membership lists of professional organizations of auditors. Due to this common source of data, at this point a general overview of the data will be given. The respective chapters contain more specific information on the data collection and the data itself.

The studies on career advancement and inter-organizational mobility are based on a sample of Dutch auditors. The study on competition in audit markets uses data on the Belgian, German and Dutch audit markets. In all three countries under study, the right to conduct audits is restricted by law to the members of the professional organizations of auditors. ${ }^{3}$ In this regard, members of the three professional organizations, or the firms to which they belong, form the complete audit markets in the three countries studied. Furthermore, the professional organizations of auditors in Belgium, Germany and the Netherlands regularly publish membership lists containing all members (i.e. auditors) eligible to conduct audits and their affiliation and position. Also, the exact datemark of these membership lists is included.

Since these membership lists are readily available, this creates the possibility to obtain detailed results on auditor careers and audit markets. Careers of auditors are analysed by comparing successive membership lists. In this way, changes of affiliation and changes in position (i.e. promotion to partner) can be determined. Moreover, the monthly journal of the Dutch professional body of

"Both in Germany and the Netherlands there are two professional bodies of auditors. However, in each of these two countries, members of one of the wwo professionall bodies were only eligible to perform audits in the most recent period of study and during this period, they mainly provided compilation and tax services to smaller clients. For a more elaborate overview of the right to conduct (statutory) audits, see the overviews of the Belgian, German and Dutch auditing professions in Appendix A of chapter 4. 
auditors lists all its new members. This enables the determination of the starting point for tracing individual careers of auditors, the auditors ${ }^{4}$ date of qualification. To examine competition in audit markets, data on the number of auditors are used as the measure of audit firm size. ${ }^{4}$ All membership lists contain a register of audit firms which also includes the names of the auditors engaged with the respective firms. So, the distribution of market shares (i.e. the relative number of auditors per audit firm) at different points in time can be determined. Comparing successive membership lists with respect to changes in market shares of individual audit firms enables the measurement of market share mobility and entry and exit of audit firms.

\subsubsection{Final remarks}

The following chapters contain the empirical studies on auditor careers and audit markets. Each research study is presented in a separate chapter. Since every chapter encompasses a complete study, literature reviews are included in the respective chapters.

Practical implications will also be discussed in the respective chapters. However, the following general observations apply. The two studies on auditor careers contain valuable information for individual auditors as well as for audit firms. The study on inter-organizational mobility shows that the mobility of individual auditors decreases as specialization increases. This finding is also relevant for audit firms with respect to their human resource policies, e.g. the planning of auditors on engagements. By identifying characteristics of auditors who advanced to partnership, the study on career advancement is relevant for individuals who want to pursue a career in auditing as well as for hiring policies of audit firms. The study on audit markets contains valuable information for policy makers, such as the European Commission, as it addresses the measurement of competition in audit markets. A dynamic analysis of market structure appears to provide more insight into competition as compared to the frequently used static concentration analyses.

A final remark relates to the confusion of ideas in the career literature regarding employee mobility. Various terms are used to denote employee mobility but they are not used systematically. To clarify this, the two basic forms of mobility will be presented here. First, employees may leave their current position for another, usually better, position in the same firm. This is referred to as intra-

\footnotetext{
${ }^{4}$ As will be discussed in chapter 4 , this firm size measure correlates highly with (audit) feeincome.
} 
organizational mobility. Second, employees may leave their current position for a position in another firm. This is referred to as inter-organizational mobility. In the literature, however, these terms are not used systematically. ${ }^{5}$ To avoid confusion with the term mobility, in this dissertation, career advancement is used to indicate promotion (i.e. a form of intra-organizational mobility). The terms interorganizational mobility and mobility are used to indicate individuals leaving their current firm for another firm.

The structure of this dissertation is as follows. In chapter 2, the career advancement of auditors in audit firms will be examined. After that, chapter 3 presents a study into the inter-organizational mobility of auditors. The economics of audit markets is addressed by an analysis of market structure of three audit markets in chapter 4. Finally, chapter 5 provides a summary, discusses the implications and limitations of this research and provides suggestions for future research.

"Many studies use the term turnover. Tumover can be defined as leaving the current position. Accordingly, turnover might undicate intra- as well as inter-organizational mobility. Nevertheless, most studies on auditor mobility use the term turnover to indicate the migration of auditors to other firms. Moreover, in some studies the term job mobility is used to indicate turnover. Other terms referred to in mobility studies are upward mobility and career advancement. Both indicate promotion, which is usually a form of intra-organizational mobility. 


\section{Chapter 2 \\ Career advancement in audit firms '}

This chapter examines factors which affect he career advancenent of auditors Career advancement is measured un terins of pronotion io partmer and promoilen veloeity. The ex planatory variables are edication. age at gualificantion, audit firm size, and elange of audit tirm the rindings, based on data obtained r ron he memberiluif lists of the Duteli professional body of auditors, ndicate that university educated audifors are more likely to become partners and adyance (nster trwarids partnership. Howerer, the findings also show that greater age at qualification decreases the probabilly of piogriessing to parthership. Sinee universiny graliates qualify at an earlier age the main reason bebind the

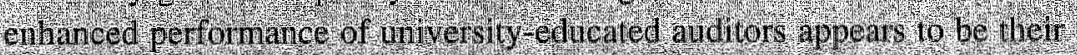
nore rapid ad wancement towards gualification as auditors. Furthermore; prometion velocity is pestively related to age at qualification and is

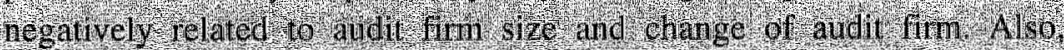
audion of large fims or auditars who change dudit fitm bave a lower probabilty of attaving partnciship. The findings further indicate that unversity edicated. aud tors, is compared to non unverilly educated

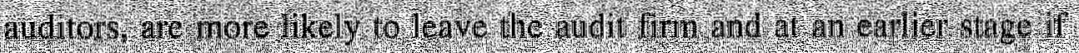
they camnot atu ain panthership

\subsection{Introduction}

There is relatively little research into factors explaining the career advancement of auditors. This is surprising considering the number of individuals who pursue a career in public accounting and the resources audit firms devote to hire and train auditors. Furthermore, the ultimate success of audit firms is clearly linked to the

\footnotetext{
1 This chapter is based on Meuwissen (1998)"
} 
quality of their auditors. Since there is much discussion about the appropriate educational preparation of auditors, a question of considerable interest is whether career advancement is influenced by educational background. Therefore, previous studies on the determinants of career advancement of auditors primarily focussed on education [see, e.g. Siegel (1987); Wright (1988); Spiceland, Siegel and George (1992)]. These studies conclude that individuals with more education (i.e. a Master of Business Administration degree) are promoted more quickly than individuals with just a first degree. Only two studies also used other factors besides education for explaining the career advancement of auditors [see Bhamornsiri and Guinn (1991); and Hunton and Wier (1996)]. Again, additional academic education appeared to be the principal factor.

However, the discussion regarding the appropriate educational preparation for auditors is not only restricted to university education per se, but also extends to the amount of practical training. A central question in this respect is whether the education of auditors needs to be academically-oriented or practically-oriented. From an economic perspective, this is the choice between investing in academic and practical skills to achieve a required knowledge level. The two alternatives differ with respect to the time auditors are productive: auditors obtaining practical skills are already productive during their traineeship, while auditors taking additional academic education are not productive during their educational period. Consequently, the forgone earnings of additional academic education need to be offset by higher future earnings as an auditor, for example, by becoming partner at an earlier age.

The Netherlands provides a unique setting to test differences between university and non-university training. The Dutch professional body 'Koninklijk Nederlands Instituut van Registeraccountants' (Royal NIVRA), allows both a university education programme and a non-university education programme (NIVRA programme). ${ }^{2}$ The NIVRA programme is practically-oriented since

\footnotetext{
In the Netherlands two types of auditors are allowed to perform statutory audits: AccountantsAdministraticconsulenten (certified accountants) and registeraccountants (registered auditors). Certified accountants were granted the right to conduct statutory audits by the 1993 Act on Certified Accountants, and registered auditors were granted this right by the 1962 Act on Registered Auditors which came into effect in 1967. The professional bodies of certified accountants (NOvAA) and registered auditors (Royal NIVRA) regulate entry to the profession. Until 1993 only Royal NIVRA was responsible for licensing auditors. Since this study concentrates on auditors who were licensed before this date, only registeraccountants are considered. Their two main educational programmes are briefly discussed below. It should be noted, however, that this description applies to auditors who entered the profession during the period of study.
} 
students are employed with an audit firm or elsewhere and combine audit work with studies during the education programme. The delineating characteristic of this non-university education programme is the application of knowledge on-thejob. In contrast, university-educated auditors possess far less practical experience but their educational programme is regarded as broader, which provides them with additional scientific skills and capabilities not generally possessed by those who have followed the NIVRA programme.

In recent years the optimal educational preparation for auditors has been widely discussed in the Netherlands. A report by the professional body Royal NIVRA [Koninklijk Nederlands Instituut van Registeraccountants (1980)] stated that future auditors need to receive a broad education to cope with the increasing demands of the expansive and more complex profession which is emerging. That report concluded that some aspects of the NIVRA education programme need to be revised to give potential auditors a more general education. Universities offer such a broad education programme. Accordingly, the chairman of the NIVRA education programme suggested a reorientation in the education of auditors and questioned whether Royal NIVRA ought to continue the NIVRA education programme [Elte (1992)]. ${ }^{3}$

A basic question addressed in this study is whether differences in educational background affect the career advancement of auditors. Apart from educational background, this study also examines whether age at qualification, audit firm size and change of audit firm influence the career advancement of auditors. Individuals who qualify at an early age can be expected to possess above

\section{2(...continued)}

Royal NIVRA allows two educational programmes to become 'registeraccountant': a uniwersity programme and a NIVRA programme. The NIVRA programme is regarded as a nonuniversity education programme. Most students enter the NIVRA education programme after completing secondary school. The course of study for the NIVRA programme extends over eight years of part-time study. Students are employed by audit firms or elsewhere and follow courses for the NIVRA programme on a part-time basis (about one day a week). The university education programme consists of a full-time, four-year degree programme (this was a six-year program in a large part of the period of study) in 'bedrijfseconomie' (i.e. 'business administration'). After completion of the degree programme in 'bedrijfseconomie", students follow a one- or two-year post-graduate programme in auditing on a part-time basis towards fulfilment of the requirements to become an auditor [Zeff, wan der Wel and Camfferman (1992); Koninklijk Nederlands Instituut van Registeraccountants (1995)]. During the post-graduate programme in auditing students are employed by audit fims or elsewhere.

${ }^{3}$ Internationally a similar discussion has taken place. The Bedford Report by the American Accounting Association (1986) stressed the need for additional education requirements for entrylevel auditors in the US and in this way the discussion in the Netherlands is comparable to the debate within the American accounting profession. 
average abilities (e.g. IQ). And according to human capital theory, ability is regarded as an important variable for explaining earnings differences and career advancement [see Becker (1964); Mincer 1974)]. Accordingly, the age at qualification (as a proxy for ability) can be expected to influence career advancement. Also, audit firms vary significantly in their range of clients and work, employment practices (e.g. promotion), size, and hierarchical grades. It can be expected that the characteristics of an audit firm will have a differential effect on the auditor's career. Furthermore, the variable "change of audit firm' may contribute to explaining career advancement since auditors who are not able to advance to partnership can switch to another audit firm to try to attain a partnership with that firm.

In identifying differences in career advancement between auditors, this study follows the careers of thirteen cohorts of auditors between 1970 and 1998 for 15 years following the date of qualification. The auditors in this study qualified between January 1970 and December 1982. The performance measures used are admission to partnership and promotion velocity.

This chapter proceeds as follows. Section 2.2 presents a brief review of the relevant literature. Section 2.3 develops hypotheses about the determinants of career advancement. Section 2.4 describes the method and data collection, while section 2.5 reports the results. The final section provides conclusions and suggestions for further research.

\subsection{Previous research}

To date only limited attention has been given to factors explaining the career advancement of auditors. Only in recent years, some US-studies have examined the influence of educational background on career advancement and on-the-job performance of auditors [Siegel (1987); Siegel and Rigsby (1988); Wright (1988); Alford, Strawser and Strawser (1990); Deppe, Smith and Stice (1992); Siegel, Rigsby and Leavins (1992); Spiceland, Siegel and George (1992)]. These papers focussed on the career progress of auditors in the Big Eight audit firms to identify whether differential education contributes to success in public accounting. ${ }^{4}$ In

"The Big Eight audit firms are: Arthur Andersen, Arthur Young, Coopers \& Lybrand, Deloitte, Haskins \& Sells, Enst \& Whinney, KPMG, Price Waterhouse, and Touche Ross. Due to the 1989 mergers of Arthur Young and Enst \& Whinney into Emst \& Young, and Deloitte, Haskins \& Sells and Touche Ross into Deloitte \& Touche, it should be noted that the Big Eight is Big Six at the time this study was conducted. 
these studies a commonly used measure of success is advancement to the various staff levels of an audit firm. ${ }^{5}$

Siegel (1987) provides evidence that educational preparation influences the performance of auditors. He collected data on the performance of auditors employed with five large accounting firms who were hired shortly after college graduation and were continuously employed with the firm since that time. Siegel (1987) concluded that MBAs outperform BAs by receiving better overall evaluations from their audit firm supervisors, exhibiting lower turnover, and achieving faster promotion rates to senior and manager levels. Nevertheless, due to the relatively small number of subjects, he was not able to draw a conclusive inference at partner level.

Wright (1988) tracked 110 entry level auditors over a nine-year period (1973-1981) to compare the performance of MBAs and BAs. ${ }^{6}$ The data were obtained from the San Francisco offices of five of the Big Eight firms. He used three performance measures: advancement to various staff levels (semi-senior, senior, supervisor, and manager), staff turnover, and salary increases. ${ }^{7}$ Wright (1988) concluded that MBAs advance more rapidly to various staff levels in the firm. However, he found no significant differences in staff turnover and salary increases.

Studies by Siegel and Rigsby (1988) and Siegel, Rigsby and Leavins (1992) examined the relative contribution of internships and graduate education to the career advancement of auditors. Siegel and Rigsby (1988) analysed annual evaluations of auditors by their audit firm as well as their career advancement. They found a positive relationship between participation in an internship programme (i.e. additional practical education) and career advancement. Siegel,

${ }^{5}$ Several studies have examined whether gender influences success in public accounting [see, e.g. Pillsbury, Capozzoli and Ciampa (1989); Anderson, Johnson and Reckers (1994); Larkin (1997)]. However, these studies did not measure career advancement and are therefore not considered in this overview. Although the effect of gender on career advancement is regarded as an interesting research topic [see Hooks (1992)], this study does not address gender as an explanatory wariable for two reasons. This dissertation examines auditor careers from an economic perspective, and gender does not fit well in such a framework. Furthermore, if gender would be used as a variable, the number of female auditors in this study is too small to obtain sensible results on the gender variable.

${ }^{6}$ The MBAS were individuals holding a Master of Business Administration degree with a concentration in accounting. The BAs were undergraduate accounting majors with a bachelor's degree.

${ }^{7}$ Turnover is reflected by: (1) time with the firm and (2) percent of auditors still with the firm at the end of the test period. 
Rigsby and Leavins (1992) examined the influence of both internship experience and education on promotion. Data were collected on the performance evaluation and promotion time of auditors of five large US audit firms. They found that auditors with a master's degree have higher performance evaluations and promotion rates than auditors with only a bachelor's degree. Siegel, Rigsby and Leavins (1992) did not observe differences in promotion rates between MBAs and BAs with internship experience. However, they only analysed promotions to the senior and manager level.

Spiceland, Siegel and George (1992) introduced survival analysis in the auditor career advancement literature. ${ }^{8}$ They investigated the association between post-baccalaureate education and two measures of career advancement: promotion time and turnover. Data were obtained on auditors of five large US audit firms and survival analysis was used to test for differences in career advancement. The results indicated that both promotion time and turnover is less for auditors with post-baccalaureate education. However, they did not examine differences in career advancement at partner level.

Furthermore, studies by Alford, Strawser and Strawser (1990) and Deppe, Smith and Stice (1992) provide moderate support for the influence of educational background on career advancement. Alford, Strawser and Strawser (1990) examined a group of new partners in Big Eight accounting firms to determine whether post-baccalaureate education contributes to the attainment of a partnership. The data included all promotions to partner in Big Eight US-offices during the ten years 1978-1987. The attainment of partnership is used as a measure of success in public accounting. Alford, Strawser and Strawser (1990) report that post-baccalaureate education, although rather weakly, enhances the probability of advancing to partnership."

A study by Deppe, Smith and Stice (1992) investigated the performance of bachelor's and master's degree graduates from Brigham Young University in audit practice. They selected student-cohorts which had graduated in the period 1979 1988 and gathered data on differences in promotions, pass rates at the Certified Public Accountant (CPA) examination, and turnover from graduation until 1988 . Deppe, Smith and Stice (1992) show that master's graduates, compared to bachelor's graduates, need fewer years to pass the CPA examination, have a lower

\footnotetext{
Survival analysis is a statistical technique which specifically incorporates the effects of timedependent factors such as promotion velocity in explanatory models. For a more elaborate overview, see section 2.4 and Chapter 3 .

"Post-baccalaureate education programs include the master"s of accountancy programs and MBA programs with a concentration in accounting.
} 
turnover, but do not have a higher promotion velocity. To compare the promotion velocity of BAs and MBAs, four promotion levels were identified. Restricted by the short time period, few subjects achieved all four promotions. Thus, essential differences at the fourth promotion level (i.e. partner level) could not be derived.

In summary, all these studies concentrated on education as the most important factor explaining career advancement of auditors, and in general they found a positive relationship between graduate education and career advancement. Only two recent studies by Bhamornsiri and Guinn (1991) and Hunton and Wier (1996) investigated factors other than education which might contribute to career advancement in audit firms.

Bhamornsiri and Guinn (1991) examined a group of partners admitted to partnership during 1988 in one of the Big Eight accounting firms to identify individual factors which have contributed to their progress. They provide evidence that CPAs having advanced degrees progress faster towards partnership in the audit area than those only having a bachelor's degree. However, the majority of the partners in this survey did not themselves perceive that education beyond a bachelor's degree contributes to the possibility of a promotion to partner. Furthermore, they found that technical competence, communication skills and interpersonal skills are important capabilities contributing to the advancement to partner.

Hunton and Wier (1996) extended previous research by incorporating individual as well as organizational variables. Following Ferris, Buckley and Allen (1992), they link both individual factors such as education, gender, experience and professional certification and organizational factors such as company size and industry to career advancement, measured by time to promotion and time to turnover. The careers of junior accountants as well as senior accountants in private industry were tracked for a period of 60 months after entering their job. Using survival analysis, Hunton and Wier (1996) found that the level of education of both junior and senior accountants was positively related to promotion velocity and time to turnover. Professional certification, gender and prior experience were also found to have a significant effect on promotion velocity.

In general, previous studies demonstrate a positive association between additional academic education and career advancement. The present study seeks to contribute to this literature by looking at the effect of university education per se. It makes use of particular institutional arrangements in the Netherlands where auditors are also trained outside academe.

Furthermore, although previous research demonstrates a positive association between additional academic education and success in the auditor 
examinations [see, e.g. Dunn and Hall (1984)], successful performance in the education programme has not been studied in relation to career advancement. Also, earlier research has not addressed the relationships between either audit firm size or change of audit firm and career advancement.

\subsection{Hypothesis development}

This study uses two measures of career advancement which were also used in previous studies on auditor performance. The first measure is the advancement to various staff levels in an audit firm. In this study it is interpreted as the admission of an auditor to the partnership of an audit firm. The second measure is promotion velocity. This is defined as the period of time between qualification as an auditor and admission to partnership. Rapid progress towards partnership in an audit firm can be considered as good performance in public accounting.

Career advancement varies among auditors. There are several factors which might be associated with the relative career advancement of these individuals. Such a list would include individual variables, as well as organizational variables [McCormick and Ilgen (1980)]. This study concentrates on two individual explanatory variables (education and age at qualification) and on two organizational explanatory variables (audit firm size and change of audit firm). ${ }^{10}$

The first explanatory variable is the education of the auditor. The overall conclusion of the US-studies discussed earlier is that holders of a master's degree are more successful in audit practice than auditors who hold only a bachelor's degree. Alford, Strawser and Strawser (1990) show that a broad education enhances the probability of achieving partnership. Furthermore, studies by Siegel (1987), Wright (1988), Bhamornsiri and Guinn (1991), Siegel, Rigsby and Leavins (1992) Spiceland, Siegel and George (1992) and Hunton and Wier (1996) indicate that broad education enhances the auditor's promotion velocity. In this study, a distinction is made between non-university education (NIVRA programme) and university education. The major advantage of the NIVRA programme is the application of knowledge on-the-job, whereas universityeducated auditors benefit from a more general education. This more general

10 Bhamornsiri and Guinn (1991) and Hunton and Wier (1996) have examined additional variables with respect to career advancement. However, these variables either do not fit in an economics framework (e.g. communication skills, and interpersonal skills) or are not relevant for the current study (e.g. professional certification: all individuals in this study are certified as auditors, industry: the study focuses on the audit industry). 
knowledge should provide university-educated auditors with a higher promotion probability and/or a higher promotion velocity to recover the deferred revenues by not taking the NIVRA programme. That is, university-educated auditors defer revenues by taking additional full-time education instead of going through the NIVRA programme, which would yield them immediate returns. It can therefore be hypothesized that:

$\mathrm{H}_{\|} \quad$ University-educated auditors are more likely to advance to partnership as compared to non university-educated auditors.

$\mathrm{H}_{2}$ University-educated auditors are more likely to have a higher promotion velocity as compared to non university-educated auditors.

The second variable is the age of the auditor at the moment of qualification. The time a student needs to finish his/her studies to become an auditor varies. This can either be caused by the fact that a student progresses faster or slower than average or by the educational path chosen by the student. For the subjects of this study their university education consisted of a six-year undergraduate programme and another two years for the post-graduate programme. The NIVRA course of study also extends over eight years, but due to the combination of practical training and education a student is much more likely to face a delay in study time. Finishing studies within the nominal time, or becoming an auditor in less than average time, could be indicators of an individual with high abilities. According to human capital theory, ability is an important variable for explaining earnings differences and consequently career advancement [see Becker (1964); Mincer (1974)]. Hence, individuals who become auditors at "an above average age" will have a lower probability of achieving a partnership in public accounting and will have a slower promotion velocity. "Hence, it is hypothesized that:

$\mathrm{H}_{3} \quad$ Auditors having a high study velocity (relatively young age at qualification) are more likely to advance to partnership.

$\mathrm{H}_{4}$ Auditors having a high study velocity (relatively young age at qualification) are more likely to have a high promotion velocity.

The third variable is the audit firm size. The size of an audit firm may have a major influence on the career advancement of auditors. Unlike small audit firms,

"A similar prediction can be made according to the "Tournament Model" of Rosenbaum (1984), which is rooted in human capital theory [see Lazear and Rosen (1981)]. The "Tournament Model." suggests that success is very important in the early stages of one"s caper. The model predicts that slow progress in the early stages of one's career will result in slow (or even no) progress in later career stages. 
large audit firms have structured in-house professional development programmes for their employees, and they have more standardized career tracks leading to internal promotions for filling partner positions. The economic rationale for the establishment of these standardized career tracks leading to internal promotions is that they act both as a monitoring device to evaluate employees and as a means for protecting investments in human capital [Doeringer and Piore (1971)]. Accordingly, the results of a study by Idson (1989) indicate that larger employers provide their employees better opportunities for career advancement within the firm in an attempt to protect the relatively higher investments in their employees.

On the other hand, it can be argued that large audit firms as compared to small audit firms possess more client-specific quasi-rents and therefore have reduced incentives to 'cheat' in order to retain clients [DeAngelo (1981b)]. ${ }^{12}$ The costs of an individual partner 'cheating' are therefore larger. This would imply that these larger audit firms screen potential partners more carefully by having higher promotion standards and longer promotion tracks. Taking both arguments into account, the resulting hypotheses are:

$\mathrm{H}_{5} \quad$ Audit firm size is related to the auditor's probability of advancing to partnership.

$\mathrm{H}_{6}$ Audit firm size is related to the auditor's promotion velocity.

The fourth variable is change of audit firm. This variable may contribute to explaining career advancement since auditors who are not able to advance to partnership can switch to another audit firm to try to attain a partnership with that firm. Consequently, it can be expected that for auditors who cannot attain partnership with their current firm, a change of audit firm will increase their probability of achieving partnership. However, since these auditors were not successful in the early stages of their careers, it can be expected that they have a lower probability of being successful in subsequent stages of their careers. Furthermore, auditors switching to another audit firm may lose their accumulated job-specific capital. This may result in a lower promotion velocity since an additional period will be required to accumulate job-specific capital with the new employer. Thus, it can be hypothesized that:

$\mathrm{H}_{7} \quad$ A change of audit firm is negatively related to the auditor's probability of advancing to partnership.

$\mathrm{H}_{8} \quad$ A change of audit firm is negatively related to the auditor"s promotion velocity.

${ }^{12}$ Client-specific quasi-rents exist because of start-up and transaction costs in auditor/client rellationships [see DeAngelo (1981a)]. 


\subsection{Methodology}

\subsubsection{Method}

Thirteen cohorts of newly qualified auditors were traced over 15 years in the period 1970-1998. ${ }^{13}$ Univariate and multivariate statistical procedures were used to identify differences in performance data for the explanatory variables. The studies by Spiceland, Siegel and George (1992) and Hunton and Wier (1996) used survival analysis to analyse career advancement claiming that this technique is better suited to the dynamic character of careers. In this study, "traditional' statistical techniques are used because career advancement is not measured dynamically. That is, this study does not make use of time varying variables to explain career advancement and the aim of this study is just to explain advancement to partnership, the event after which we assume careers become in a steady phase. Furthermore, an important feature of event histories is that they permit the comparison of all subjects, including those which have not experienced the event under study (i.e. promotion to partner). That is, no right-hand censoring occurs. However, since this study uses a 15 -year horizon, almost all promotions to partnership are considered, and only very few subjects are censored. For a more elaborate overview of event histories and survival analysis see Chapter 3 , where these techniques are used to study auditor mobility.

With respect to coverage, this study differs from Alford, Strawser and Strawser (1990) and Bhamornsiri and Guinn (1991) in that it enables the derivation of differences between those auditors who progressed to partnership and those who did not become partners. That is, the focus is on all newly-qualified auditors in a cohort and not only on auditors who advanced towards partnership. Furthermore, since complete cohorts of auditors will be studied, for the first time actual promotion probabilities in auditing can be identified. Compared to Siegel (1987), Wright (1988), Deppe, Smith and Stice (1992), Siegel, Rigsby and Leavins (1992), Spiceland, Siegel and George (1992) and Hunton and Wier (1996), this study examines a much longer performance horizon (15 years) to obtain data on the progress to partnership. Moreover, this study not only concentrates on auditors of Big Eight firms but also on all newly-qualified auditors in each cohort. Consequently, a distinction can be made between the performance of auditors at large and small audit firms. Further, previous research

13 To fully evaluate the career patterns of newly qualified auditors, a reasonable time period to attain a partnership was needed. Referring to Dutch audit practice, a 15-year horizon was considered sufficient to progress to partnership. 
has been able to identify career differences by comparing two types of university education. This study attempts to identify the effect of university education per se by comparing university and non-university education programmes. In doing this, it is assumed that students entering both educational programmes on average have equal abilities (IQ) and motivation.

This study does not identify differences in advancement to various staff levels. Only differences at the partner level are examined. As a result of data limitations it was not possible to examine the auditors' progress through promotional levels other than to partner level. However, it should be noted that the achievement of a partner position is a strong measure of long-term success in public accounting.

\subsubsection{Dafa collection}

The monthly magazine of Royal NIVRA, 'De Accountant', provided the starting. point for the data collection. 'De Accountant' continually lists all individuals who are eligible for inscription on the register of Royal NIVRA and consequently become qualified as auditors. At the time of inscription their current employer, academic degree, and date of qualification is published in "De Accountant'. The date of birth of these individuals was retrieved from the official Gazette of the Netherlands, de Staatscourant, which also lists all prospective auditors. Furthermore, 'De Accountant' provides the exact date of the admission to partnership for most of the auditors. ${ }^{14}$ In order to trace the career advancement of the auditors over the 15-year horizon periodic membership lists of Royal NIVRA were used. They list the current employer and position for all auditors. ${ }^{15}$

Owing to the fact that this study concentrates on career advancement within audit firms, those auditors who set out to become partners of an audit firm must be identified. Thus only newly qualufied auditors who were listed with an audit firm in the membership lists were considered as challengers for a partnership. ${ }^{16}$ Given the 15-year horizon and the fact that the data of January 1998 were the most recently available, thirteen cohorts of auditors who qualified in the period January

${ }^{14}$ When the auditor's date of admission to partnership was not given in 'De Accountant' the exact date was obtained either from the audit firm or from Royal NIVRA.

13 Audit firms list all their auditors and make a distinction between partners and non-partners.

${ }^{16}$ This implies that the auditors considered as challengers for a partnership in an audit firm were (1) listed with an audit firm at the moment of qualification, or (2) employed outside the audit profession at the moment of qualification but entered the profession in the 15-year period following their qualification. 
1970 - December 1982 were selected. ${ }^{17}$ In this period, 2623 individuals qualified as auditors, but 887 were never employed with an audit firm during the 15 -year period. This resulted in a sample of 1736 subjects: 1098 NIVRA-educated auditors and 638 university-educated auditors. The total sample is presented in TABLE 1, including a profile of the auditors covered in this study.

\subsubsection{Explanatory variables}

Four explanatory variables are used to explain career advancement. The first is the education of the auditor. A distinction is made between the NIVRA education and university education (Hypotheses 1 and 2). The second variable is the study velocity of an auditor. This is interpreted as the age of the auditor at the moment of qualification (Hypotheses 3 and 4). The third variable is the size of the audit firm. Audit firms are classified into two categories: Big Six and non-Big Six (Hypotheses 5 and 6) ${ }^{18}$ Auditors who switched to another audit firm before achieving partnership were classified with the new firm since this will be the ultimate firm where they try to achieve partnership. ${ }^{19}$ The fourth explanatory variable is change of audit firm. A distinction is made between auditors who remain with the same audit firm and auditors who change audit firm (Hypotheses 7 and 8 ).

Furthermore, the year of qualification will be used as a control variable. Since 13 annual cohorts of auditors are analysed, differences in career advancement might exist between the various cohorts. The 'year of qualification'variable will control for differences in career advancement between the early cohorts (1970-1976) and the later cohorts (1977-1982).

17 For the period under study, the NTVRA membership list is awailable for the years 1970 , $1971,1972,1973,1974,1975 / 1976,1978,1980,1982,1984,1986,1988,1990,1991,1992,1993$, $1994,1995,1996,1997,1998$.

18 The Big Six audit firms are: Arthur Andersen, Coopers \& Lybrand, Deloitte \& Touche, Emst \& Young, KPMG, and Price Waterhouse. During the period of study, four of these large international firms merged with large Dutch audit furms to obtain a dominant position in the Dutch audit market. The auditors who were with one of these large Dutch audit firms are also considered Big Six auditors. These Putch audit firms are (current international name): Dijker en Doornbos (Coopers \& Lybrand), Klynveld Kraayenhof \& Co (KPMG), Moret \& Limperg (Ernst \& Young), Nederlandse Accountants Maatschap (Deloitte \& Touche), and Van Dien \& Co (Coopers \& Lybrand). Arthur Andersen and Price Waterhouse did not seek cooperation with Dutch audit firms. In the remainder of this chapter, the large audit firms will be referred to as Big Six.

19 A classification with the audit firm at the time of qualification provided similar results. 


\section{TABLE 1}

Sample characteristics

\section{Panel A: Subjects included in the study}

Subjects

Number of auditors

Total number of auditors who qualified between 1970 and 1982 2623

Auditors who were never employed with an audit firm

Auditors included in the study

\section{Panel B: Sample profile}

Number of auditors per cohort

Cohort 1970101 auditors

Cohort $1971 \quad 109$ auditors

Cohort $1972 \quad 135$ auditors

Cohort 1973150 auditors

Cohort 1974117 auditors

Cohort 1975133 auditors

Cohort $1976 \quad 126$ auditors

Cohort $1977 \quad 119$ auditors

Cohort 1978137 auditors

Cohort 1979179 auditors

Cohort 1980143 auditors

Cohort $1981 \quad 146$ auditors

Cohort $1982 \quad 141$ auditors
Education:

638 university-educated auditors (37\%)

1098 non-university educated auditors $(63 \%)$

Median age at qualification

31.4 years (min 25.3 years, max. 58.3 years)

Employment at qualification

1475 auditors in public practice ( $85 \%$ )

261 auditors outside public practice (15\%)

Change of audit firm

745 auditors with change $(43 \%)$

991 auditors without change (57\%)

1736 auditors included in the study 


\subsection{Results}

\subsubsection{Introduction}

To examine the influence of the explanatory variables on career advancement, three groups of auditors are identified: partners, sole-practitioners and nonpartners. ${ }^{20}$ Of the sample of 1736 auditors, $878(51 \%)$ progressed to partnership of an audit firm. Also, 191 auditors $(11 \%)$ established themselves as solepractitioners. The remaining 667 auditors (38\%) did not progress to partnership. This analysis indicates that the actual promotion probability for newly qualified auditors is $32 \%$ (partners vs. all auditors, $878 / 2623$ ), and for auditors challenging for a partnership 51\%. This percentage seems rather high. An explanation for this finding is that auditors unable to advance to partnership with their initial audit firm will switch to another firm and try to achieve partnership with that firm. Also, when looking at the partner-to-staff ratio of Dutch audit firms in the years in which these cohorts qualified, it appears that about $55 \%$ of the auditors in audit firms are partners. This percentage decreases slowly to about $50 \%$ in 1998 . Thus, the fact that $51 \%$ of the auditors in audit firms advance to partnership reflects a partner-to-staff ratio common for Dutch audit practice.

First, results of univariate analyses on the effects of education, age at qualification, audit firm size and change of audit firm on the probability of advancing to partnership, and on promotion velocity are presented. These univariate results indicate the separate effects of the explanatory variables on career advancement. After that, the influence of the explanatory variables on career advancement is analysed by multivariate methods in paragraph 2.5.3. Furthermore, paragraph 2.5.4 presents an analysis of career advancement in Big Six audit firms, while paragraph 2.5 .5 contains an analysis of auditors who did not advance to partnership.

\subsubsection{Univariate analyses}

\section{The probability of achieving partnership}

TABLE 2 shows that (at the 0.05 level) significantly more university graduates $(56 \%)$ progressed to partnership than did NIVRA-educated auditors (chi-square $=$

${ }^{20}$ A distinction is made between partmers of audit firms and sole-practitioners. Auditors who have no opportunity to advance to partnership in an audit firm can establish themselves as solepractitioners. To provide a more homogeneous group, sole-practitioners are eliminated. Nonpartners are employed auditors. They neither established themselves as sole-practitioner nor progressed to partnership. 
13.739, Idf, $p=0.000$ ). Further, to deal with the possibility that auditors advancing to partnership from outside audit practice influence the results, an additional test was conducted only on those auditors who were engaged with an audit firm at the moment of qualification. It can be expected that factors not associated with auditor performance determine the career advancement of auditors from outside audit practice. For this subsample $(n=1475)$, even stronger evidence can be provided that university graduates more often progressed to partnership than did NIVRA-educated auditors (chi-square $=17.763,1 \mathrm{df}, p=0.000$ ). Hence, the univariate anallysis supports hypothesis 1.

\section{TABLE 2}

Univariate analysis:

The effect of education on the probability of achieving partnership

Total sample

Probability of achieving partnership
Education $^{\mathrm{a}}$

NIVRA University
Subsample auditors employed by audit firms at the moment of qualification

$$
\begin{array}{ccccccc}
\text { Partner } & 47.5 \%(n=521) & 56.0 \%(n=357) & 46.8 \%(n=439) & 55.5 \% \quad(n=298) \\
\text { Sole-practitioner } & 10.9 \%(n=120) & 11.1 \% \quad(n=7 !) & 9.6 \% \quad(n=90) & 10.0 \% \quad(n=54) \\
\text { Non-partner } & 41.6 \% \quad(n=457) & 32.9 \%(n=210) & 43.6 \%(n=409) & 34.5 \% \quad(n=185) \\
\text { Total } & 100.0 \%(n=1098) & 100.0 \%(n=638) & 100.0 \%(n=938) & 100.0 \% \quad(n=537)
\end{array}
$$

"The computed chi-square for the effect of education on the performance variable partner/nonparther is 13.739 at $1 \mathrm{df}(p=0.000)$.

" The computed chi-square for the effect of education on the performance variable partner/nonpartner is 17.763 at $1 \mathrm{df}(p=0.000)$.

Hypothesis 3 relates age at qualification to the probability of achieving partnership. As indicated in TABLE 3, auditors who advanced to a partnership with an audit firm are respectively 3.8 and 2.8 years younger at the moment of 
qualification than sole-practitioners and auditors who did not advance to partner. A $t$-test indicates that the difference in age at qualification between partners and non-partners ( 31.0 years vs. 33.8 years) is statistically significant at the 0.05 level ( $\mathrm{t}$-value $=13.213, p=0.000)$. This suggests that audtors who qualify at a relatively young age have a higher probability of advancing to partnership. Accordingly, hypothesis 3 is supported. Apparently, students finishing studies in less than the average time possess better analytical and technical capabilities to perform effectively as auditors and, additionally, are able to gain more expertence as auditors. Both factors may affect advancement to partnership. However, should be noted that the age at qualification is an offsetting factor against the experience of an auditor. Consequently, the effect of age at qualification needs to be interpreted in this perspective.

\section{TABLE 3}

Univariate analysis:

The effect of age at qualification on the probability of achieving partnership

Probability of

achieving partnership
Age at qualification ${ }^{a}$

31.0 years $(\mathrm{n}=878)$

34.8 years $(n=191)$

33.8 years $(n=667)$

Average

32.5 years $(\mathrm{n}=1736)$

a The t-value for the effect of age at qualification on the performance variable partner/nom-partner is $\mathbb{1 3 . 2 1 3}(p=0.000)$.

The results of the univariate analysis of the effect of audit firm size on the probability of achieving partnership (hypothesis 5) are shown in TABLE 4. A chisquare test indicates a statistically significant difference (at the 0.05 level) between the probability of achieving partnership in Big Six and non-Big Six audit firms (chi-square $=118.401$, Idf, $p=0.000$ ). Hence, hypothesis 5 can be 
supported. Furthermore, the coefficient of the firm-size variable indicates that the probability of advancing to partnership is higher in non-Big Six firms. Apparently, the relatively higher investments in employees by large firms [see Idson (1989)] do not lead to greater options for career advancement in order to protect these investments. Big. Six audit firms appear to have more difficult promotion tracks as compared to non-Big Six firms.

\section{TABLE 4}

Univariate analysis:

The effect of audit firm size on the probability of achieving partnership

Probability of

achieving partnership
Audit firm size ${ }^{\text {a }}$
non-Big Six firm
Big Six firm

$\begin{array}{crrrr}\text { Partner } & 56.2 \% & (\mathrm{n}=452) & 45.7 \% \quad(\mathrm{n}=426) \\ \text { Sole-practitioner } & 23.8 \% & (\mathrm{n}=191) & 0.0 \% \quad(\mathrm{n}=0) \\ \text { Non-partner } & 20.0 \% & (\mathrm{n}=161) & 54.3 \% \quad(\mathrm{n}=506) \\ & & & \\ \text { Total } & 100.0 \% & (\mathrm{n}=804) & 100.0 \% \quad(\mathrm{n}=932)\end{array}$

a The computed chi-square (two-tailed) for the effect of audit firm size on the performance variable partner/non-partner is $118.40 \mathrm{~d}$ at $1 \mathrm{df}(p=0.000)$.

is The $0 \%$ score of the Big Six firm category for sole practitioners results from the classiffcation rule that sole practitioners ${ }^{5}$ firms automatically classify as non-Big Six firms.

The results in TABLE 5 indicate that auditors changing audit firms have a lower probability of achieving partnership. A chi-square tests indicates that the difference between auditors who remained with their initial audit firm and those who did not is statistically significant at the 0.05 level (chi-square $=4.430,1 \mathrm{df}$, $p=0.035$ ). This is consistent with hypothesis 7 . Furthermore, the relatively high score of sole practitioners on the change of audit firm variable $(19.5 \%$ change of firm vs. $4.6 \%$ no change of firm) indicates that most sole practitioners decided to start their own firm after being employed by other audit firms. 


\section{TABLE 5}

Univariate analysis:

The effect of change of audit firm on the probability of achieving partnership

$\begin{array}{cc}\text { Probability of } & \text { Change of audit firm } \\ \text { achieving partnership } & \text { No change of firm } \quad \text { Change of firm }\end{array}$

Total

$\begin{array}{rrrr}56.2 \% & (n=557) & 43.1 \% \quad(n=321) \\ 4.6 \% & (n=46) & 19.5 \% \quad(n=145) \\ 39.2 \% \quad(n=388) & 37.4 \% \quad(n=279)\end{array}$

Non-partner

$100.0 \% \quad(\mathrm{n}=991)$

$100.0 \%(n=745)$

a The computed chi-square for the effect of change of audit firm on the performance variable partner/non-partner is 4.430 at $1 \mathrm{df}(p=0.035)$.

\section{Promotion velocity}

Parametric t-tests were used to compare the promotion velocity of universityeducated auditors and NIVRA-educated auditors. Using a 0.05 significance level, the promotion velocity of university-educated auditors $(6.4$ years $)$ was significantly more rapid (t-value $=3.850,876 \mathrm{df}, p=0.000$ ) than that of NIVRAeducated auditors ( 7.2 years). This indicates support for hypothesis 2 .

To measure the promotion velocity within audit firms a further t-test was performed only on those auditors who advanced to partnership with their initialaudit firms (the audit firms at the moment of qualification). For university graduates the promotion velocity within audit firms is significantly higher than for NIVRA-educated auditors (at the 0.05 level). This finding holds for Big Six ( 6.7 vs. 7.7 years) as well as for non-Big Six firms ( 4.0 vs. 5.2 years). These results are even more remarkable considering the fact that, at the moment of qualification, NIVRA-educated auditors have more practical experience (about six years), and have consequently been with their firms longer than university graduates. This indicates that despite their disadvantage in practical experience and duration of relationship with the audit firm, university graduates compete effectively in the earlier stages of their career and typically outperform NIVRA-educated auditors. 
To help visualise the promotion velocity, FIGURE 1 shows the cumulative percentages of admissions to partnership of the 521 NIVRA-educated partners and the 357 university-educated partners. The results of the effect of education on the promotion velocity are shown in Panel A of TABLE 6. This table also contains the results of the univariate analyses on the effects of age at qualification, audit firm size and change of audit firm on promotion velocity. However, the effects of these three explanatory variables on promotion velocity are not visualized.

FIGURE 1

Univariate analysis:

A graphical representation of the effect of education on promotion velocity

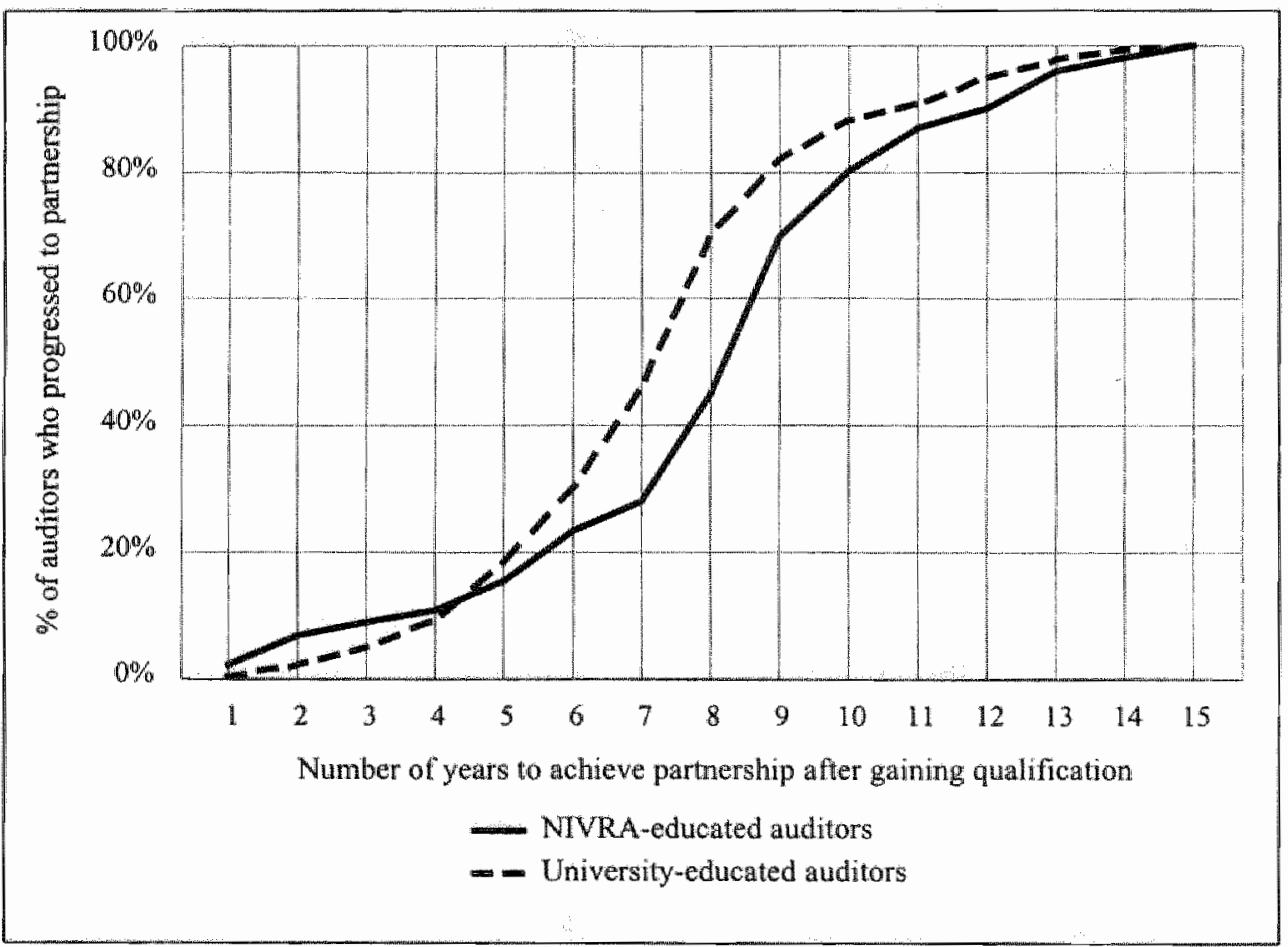

Parametric t-tests were performed to assess whether promotion velocity is affected by age at qualification, audit firm size and change of audit firm (hypotheses 4, 6 and 8). As previously mentioned, results are shown in TABLE 6. Panel B shows the results of the effect of age at qualification on promotion velocity. This analysis 
indicates a statistically significant difference (at the 0.05 level) between the promotion velocity of auditors with a relative low and high age at qualification (tvalue $=3.756,876 \mathrm{df}, p=0.000$ ). However, hypothesis 4 is not confirmed because the coefficient of this variable is in the opposite direction of that hypothesized. Promotion velocity is negatively related to age at qualification.

Results of the effect of audit firm size on promotion velocity are presented in Panel C of TABLE 6. Hypothesis 6 can be supported since the difference in promotion velocity of auditors in non-Big Six and Big Six firms is statistically significant at the 0.05 level ( $t$-value $=-9.104,876 \mathrm{df}_{,} p=0.000$ ). Additionally, the negative coefficient indicates that auditors in Big Six firms have a lower promotion velocity as compared to auditors in non-Big Six firms. As previously noted, the relatively higher investments in employees by large firms [see Idson (1989)] apparently do not lead to greater options for career advancement in order to protect these investments. Big Six audit firms appear to have more difficult promotion tracks as compared to non-Big Six firms, lending support to the arguments following from DeAngelo (1981b).

Finally, Panel D of TABLE 6 shows the results of the univariate analysis on the effect of change of audit firm on promotion velocity. In line with hypothesis 8 , it appears that auditors who remain with the same audit firm advance faster to partnership (t-value $=-5.873,876 \mathrm{df}, p=0.000$ ). The lower promotion velocity of auditors switching to another audit firm is probably due to the loss of job-specific capital. An additional period will be required to accumulate job-specific capital with the new employer before advancing to partnership.

\subsubsection{Multivariate analyses}

\section{The probability of achieving partnership}

The hypotheses 1, 3,5 and 7 about the influence of the explanatory variables on the probability of achieving partnership were tested using logistic regression. To assess this influence sole practitioners were excluded from the analyses. The results of the logistic regression are reported in TABLE 7. First, Panel A of TABLE 7 reports the correlation matrix for the variables that appear in the model. The highest correlations were found between education and age at qualification ($0.274)$, and between audit firm size and change of audit firm $(-0.239)$. These moderately low correlations suggest no collinearity problems between the explanatory variables. Therefore, all explanatory variables are included in the logistic regression analysis. 


\section{TABLE 6}

Univariate analysis:

The effect of education, age at qualification, audit firm size and change of audit firm on the promotion velocity

Panel $A$ : The effect of education on promotion velocity
NIVRA
University
Promotion velocity
7.2 years $(n=521)$
6.4 years $(n=357)$

Panel $B$ : The effect of age at qualification on promotion velocity ${ }^{b}$

Promotion velocity

Younger than median age

Older than median age

at qualification $(\leq 31.4 \mathrm{yrs})$ at qualification $(>31.4 \mathrm{yrs})$

7.1 years $(n=550)$

6.2 years $(n=328)$

Panel C: The effect of audit firm size on promotion velocity ${ }^{c}$
non-Big Six firm
Big Six firm
Promotion velocity
6.0 years $(n=452)$
7.8 years $(n=426)$

Panel D: The effect of change of audit firm on promotion velocity ${ }^{\text {d }}$
No change of firm
Change of firm
Promotion velocity
6.4 years $(n=557)$
7.6 years $(n=321)$

a The t-value for the effect of education on the performance variable promotion velocity is 3.850 at $876 \mathrm{df}(p=0.000)$.

"The t-value for the effect of age at qualification on the performance variable promotion velocity is 3.756 at 876 df $(y=0.000)$.

- The t-value (two-tailed) for the effect of audit firm size on the performance variable promotion velocity is -9.104 at 876 df $(p=0.000)$.

"The t-value for the effect of change of audit firm on the perfornance variable promotion velocity is -5.873 at $876 \mathrm{df}(p=0.000)$. 
The logistic regression results are reported in Panel B of Table 7. When all explanatory variables are entered in the regression, age at qualification, audit firm. size and change of audit firm are statistically significant. The explanatory variable education is not significant at the 0.05 level (Wald Statistic $=0.409,1 \mathrm{df}$, $p=0.523$ ). Furthermore, the analysis indicates that the regression model with all explanatory variables is significant at the 0.05 level (Model Chi-Square = $343.111,5 \mathrm{df}, p=0.000$, pseudo $\mathrm{R}^{2}=0.439$ ).

The first explanatory variable entered in the regression was education. As previously indicated by the univariate results, the separate influence of education on the probability of achieving partnership is statistically significant at the 0.05 level (Wald Statistic $=14.738,2 \mathrm{df}, p=0.001$ ). However, when the second explanatory variable, age at qualification, was entered in the regression model, the influence of education disappeared. Apparently, age at qualification captures most of the influence of education. The influence of age at qualification on the probability of achieving partnership is statistically significant at the 0.05 level (Wald Statistic $=127.071,1 \mathrm{df}, p=0.000$ ). On steps three and four respectively audit firm size and change of audit firm were entered in the regression model. Both explanatory variables are statistically significant.

With respect to the hypotheses 1,3,5 and 7, only three hypotheses are statistically validated $\left(\mathrm{H}_{3}, \mathrm{H}_{5}\right.$ and $\left.\mathrm{H}_{7}\right)$. Although the coefficient of the explanatory variable education $\left(\mathrm{H}_{1}\right)$ has the predicted sign, the influence of education on the probability of achieving partnership is not significant at the 0.05 level. Hypothesis 5 predicts no direction, but the hypothesis is statistically validated because the coefficient of the explanatory variable audit firm size indicates a statistically significant relationship. The findings show that audit firm size is negatively related to the auditor's probability of advancing to partnership. Apparently, larger audit firms screen potential partners more carefully, probably owing to higher client-specific quasi-rents or brand-name collateral.

Although the univariate results show that education influences the probability of achieving partnership, the multivariate analysis reduces this influence significantly. The multivariate analysis indicates that age at qualification is a more important variable influencing the advancement to partnership. Therefore the fact that university-educated auditors have a higher probability of achieving partnership is largely the result of their relatively young age at qualification.

The control variable year of qualification is not significant at conventional levels (Wald Statistic $=2.096,1 \mathrm{df}, p=0.148$ ) in the complete model. This indicates that year of qualification has no significant effect on the probability of achieving partnership. 


\section{TABLE 7}

Multivariate analysis: logistic regression

The effect of the explanatory variables education, age at qualification, audit firm size and change of audit firm on the probability of achieving partnership

Dependent variable: Probability of achieving partnership (no partner $=0$, partner $=1$ ) Explanatory variables: Education (non-university $=0$, university $=1$ )

Age at qualification (continuous)

Audit firm size (non-Big Six $=0$, Big Six = 1)

Change of audit firm (no change $=0$, change $=1$ )

Control variable: $\quad$ Year of qualification $(1970-1976=0,1977-1982=1)$

Nr. of observations: $\quad 1545$

\section{Panel A: Correlation matrix ${ }^{a}$}

Education

1.000

Age at qualification

$$
-0.274
$$

1.000

Audit firm size

0.008

0.017

1.000

Change of audit firm

0.110

$-0.101$

$-0.239$

1.000

Year of qualification

0.051

$-0.036$

$-0.023$

0.104

1.000

Education Age at Audit firm Change of Year of qualification size audit firm qualification

\section{Panel B: Regression model}

Explanatory variable entered on step one: Education

$\begin{array}{ccccc}\begin{array}{c}\text { Hypothesized Coefficient } \\ \text { Sign }\end{array} & \begin{array}{c}\text { Standard } \\ \text { Error }\end{array} & \begin{array}{c}\text { Wald } \\ \text { Statistic }\end{array} & \text { Probability } \\ + & 0.405 & 0.108 & 14.003 & 0.002 \\ \text { ion } & -0.098 & 0.103 & 0.903 & 0.342 \\ & 0.177 & 0.080 & 4.852 & 0.028\end{array}$

Education

0.177

0.080

4.852

Model Chi-Square $=14.738$ at $2 \mathrm{df}, p=0.001$, pseudo $\mathrm{R}^{2}=0.026$ 


\section{TABLE 7 (Continued)}

Explanatory variable entered on step two: Age at qualification

\begin{tabular}{lcccrc}
\multicolumn{2}{c}{$\begin{array}{c}\text { Hypothesized Coefficient } \\
\text { Sign }\end{array}$} & $\begin{array}{c}\text { Standard } \\
\text { Error }\end{array}$ & $\begin{array}{r}\text { Wald } \\
\text { Statistic }\end{array}$ & Probability \\
Education & + & 0.008 & 0.118 & 0.005 & 0.945 \\
Age at qualification & - & -0.170 & 0.015 & 127.071 & 0.000 \\
Year of qualification & & -0.181 & 0.109 & 2.767 & 0.096 \\
Constant & & 5.837 & 0.507 & 132.636 & 0.000
\end{tabular}

Model Chi-Square $=168.526$ at $3 \mathrm{df}, p=0.000$, pseudo $\mathrm{R}^{2}=0.228$

Explanatory variable entered on step three: Audit firm size

\begin{tabular}{|c|c|c|c|c|c|}
\hline & \multicolumn{2}{|c|}{ Hypothesized Coefficient } & $\begin{array}{c}\text { Standard } \\
\text { Error }\end{array}$ & $\begin{array}{l}\text { Wald } \\
\text { Statistic }\end{array}$ & Probability \\
\hline Education & + & 0.012 & 0.123 & 0.010 & 0.922 \\
\hline Age at qualification & - & -0.180 & 0.016 & 129.534 & 0.000 \\
\hline Audit firm size & $?$ & -1.316 & 0.121 & 117.583 & 0.000 \\
\hline Year of qualification & & -0.168 & 0.114 & 2.472 & 0.119 \\
\hline Constant & & 7.026 & 0.551 & 162.632 & 0.000 \\
\hline
\end{tabular}

Model Chi-Square $=296.721$ at $4 \mathrm{df}, p=0.000$, pseudo $\mathbb{R}^{2}=0.403$

Explanatory variable entered on step four: Change of audit firm

\begin{tabular}{lcccrc}
\multicolumn{2}{c}{$\begin{array}{c}\text { Hypothesized Coefficient } \\
\text { Sign }\end{array}$} & $\begin{array}{c}\text { Standard } \\
\text { Error }\end{array}$ & $\begin{array}{r}\text { Wald } \\
\text { Statistic }\end{array}$ & Probability \\
Education & + & 0.080 & 0.126 & 0.409 & 0.523 \\
Age at qualification & - & -0.194 & 0.016 & 140.847 & 0.000 \\
Audit firm size & $?$ & -1.557 & 0.130 & 142.679 & 0.000 \\
Change of audit firm & - & -0.848 & 0.127 & 44.433 & 0.000 \\
Year of qualification & & -0.168 & 0.116 & 2.096 & 0.148 \\
Constant & 7.891 & 0.582 & 183.682 & 0.000
\end{tabular}

sor the variables measured on a dichotomous scale, the Cramer coefficient $C$ of association is calculated. 


\section{Promotion velocity}

The hypotheses 2, 4, 6 and 8 about the influence of the explanatory variables on the promotion velocity of auditors were tested using multiple regression. The results of the multiple regression are reported in TABLE 8. First, in Panel $A$ of TABLE 8, the correlation matrix suggests no collinearity problems between the explanatory variables. All correlation coefficients are moderately low. Hence, all variables are included in the multiple regression model. Second, Panel B of TABLE 8 indicates that all four explanatory variables are statistically significant at the 0.05 level and that the model is significant at the 0.05 level with an $R^{2}$ of 0.294 .

With respect to the hypotheses $2,4,6$ and 8 , the coefficients of education and change of audit firm have the predicted signs. Since all explanatory variables are statistically significant, $\mathrm{H}_{2}$ and $\mathrm{H}_{8}$ are statistically validated. That is, university-educated auditors have a higher promotion velocity than non university-educated auditors, and a change of audit firm is negatively related to the auditor's promotion velocity. $\mathrm{H}_{6}$ can also be validated as it only predicts a statistically significant relationship between audit firm size and promotion velocity, without indicating a direction. Results show that audit firm size is negatively related to the auditor's promotion velocity. The fact that large firms, as compared to small firms, invest relatively more in employees [see Idson (1989)] does not lead to greater options for career advancement as a means of protecting these investments. Big Six audit firms appear to have stiffer promotion tracks as compared to non-Big Six firms, probably because of a higher client-specific brand-name collateral. The findings further indicate that $\mathrm{H}_{4}$, on the effect of age at qualification on promotion velocity, is not validated. This contrasts with human capital theory, because it can be expected that individuals finishing studies within the nominal time possess above average abilities, which will provide them with a higher promotion velocity. ${ }^{21}$ However, the average age on admission as partners shows that the higher promotion vellocity does not fully compensate auditors for the longer period of study. Hence, in the end, their age at admission to partnership is higher.

Furthermore, the control variable year of qualification is not significant at conventional levels (t-value $=-0.634, p=0.526$ ) in the complete model. This indicates that year of qualification has no significant effect on the promotion velocity of auditors.

2t This also contrasts with the Tournament Model of Rosenbaum (1984) because it can be expected that individuals finishing studies within the nominal time will retain this velocity in their subsequent career stages and thus show a higher promotion velocity. 


\section{TABLE 8}

Multivariate analysis: multiple regression

The effect of the explanatory variables education, age at qualification, audit firm size and change of audit firm on promotion velocity

Dependent variable: Promotion velocity (continuous)

Explanatory variables: Education (non-university $=0$, university $=1$ )

Age at qualification (continuous)

Audit firm size (non-Big Six =0, Big Six = 1)

Change of audit firm (no change $=0$, change $=1$ )

Control variable: $\quad$ Year of qualification $(1970-1976=0,1977-1982=1)$

Number of observations: 878

Panel A: Correlation matrix ${ }^{\mathrm{a}}$

Education

1.000

Age at qualification

$-0.204$

Audit firm size

0.027

1.000

Change of audit firm

0.089

0.115

1.000

Year of qualification

0.047

$-0.054$

$-0.240$

1.000

0.028

$-0.040$

0.116

1.000

Education Age at Audit firm Change of Year of qualification size audit firm qualification

Panel B: Regression model

Hypothesized Coefficient Standard t-value Probability Sign Error

Education

Age at qualification

Audit firm size

$\begin{array}{rr}- & -1.316 \\ + & -0.160 \\ ? & 2.389 \\ + & 2.135 \\ & -0.114 \\ & 9.947\end{array}$

0.188

$-6.988$

0.000

0.027

$-5.923$

0.000

0.192

12.434

0.000

Change of audit firm

0.200

0.000

Year of qualification

0.180

10.670

0.526

Constant

0.892

$-0.634$

0.000

F-Statistic $=67.693,5 \mathrm{df}, p=0.000$

$\mathrm{R}^{2}=0.294$

Adjusted $\mathrm{R}^{2}=0.302$

a For the variables measured on a dichotomous scale, the Cramer coefficient $C$ of association is presented. 


\subsubsection{Career advancement in Big Six audit firms}

An analysis of the career advancement of auditors in Big Six firms is undertaken to assess whether the results on the whole sample also hold for the large international audit firms. To this end, only a multivariate analysis will be conducted. Furthermore, the explanatory variable audit firm size is not included since the analyses are restricted to the Big Six audit firms.

TABLE 9 reports the results on the multivariate analysis on the effect of the explanatory variables education, age at qualification and change of audit firm on the probability of achieving partnership in Big Six audit firms. The analysis includes a total of 1174 auditors who were engaged with Big Six audit firms during the 15-year period of study. The results for this subsample confirm the results observed for the whole sample. The hypotheses three (age at qualification) and seven (change of audit firm) are statistically validated, while the influence of education on the probability of achieving partnership (hypothesis 1) is not significant at the 0.05 level. Hence, the fact that university-educated auditors have a higher probability of achieving partnership in Big Six audit firms is largely the result of their relatively young age at qualification.

\section{TABLE 9}

Multivariate analysis: logistic regression

The effect of the explanatory variables education, age at qualification and change of audit firm on the probability of achieving partnership in Big Six audit firms

Dependent variable: Probability of achieving partnership (no partner $=0$, partner $=1$ ) Explanatory variables: Education (non-university $=0$, university $=1$ )

Age at qualification (continuous)

Change of audit firm (no change $=0$, change $=1$ )

Control variable: $\quad$ Year of qualification $(1970-1976=0,1977-1982=1)$

Nr. of observations: 1174

\section{Hypothesized Coefficient Standard Wald Probability}

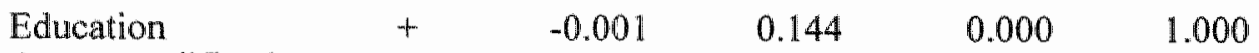

$\begin{array}{llllll}\text { Age at qualification } & - & -0.219 & 0.021 & 114.368 & 0.000\end{array}$

$\begin{array}{llllll}\text { Change of audit firm } & - & -1.626 & 0.145 & 126.202 & 0.000\end{array}$

$\begin{array}{lllll}\text { Year of qualification } & -0.187 & 0.133 & 1.970 & 0.160\end{array}$

Constant

7.398

0.687

115.978

0.000

Model Chi-Square $=270.338$ at $4 \mathrm{df}, p=0.000$, pseudo $\mathrm{R}^{2}=0.372$ 
TABLE 10 reports the results on the multivariate analysis on the effect of the explanatory variables education, age at qualification and change of audit firm on the promotion velocity in Big Six audit firms. The analysis includes a total of 506 auditors who eventually advanced to partnership with Big Six audit firms during the 15-year period of study. As evident from the table, the regression results are similar to those of the primary analysis (see TABLE 8). Hypotheses 2 and 8 are confirmed. University-educated auditors have a higher promotion velocity in Big Six audit firms as compared to non university-educated auditors, and changing audit firm negatively influences the auditor's promotion velocity in Big Six audit firms. Hypothesis 4 is not confirmed: age of qualification is positively related to promotion velocity in Big Six audit firms.

\section{TABLE 10}

Multivariate analysis: multiple regression

The effect of the explanatory variables education, age at qualification and change of audit firm on promotion velocity in Big Six audit firms

Dependent variable: Promotion velocity (continuous)

Explanatory variables: Education (non-university $=0$, university $=1$ )

Age at qualification (continuous)

Change of audit firm (no change $=0$, change $=1$ )

Control variable: Year of qualification $(1970-1976=0,1977-1982=1)$

Number of observations: 506

Hypothesized Coefficient Standard t-value Probability Sign Error

Education

Age at qualification

-
+
+
$=0.000$

Change of audit firm $-1.274$

0.207

$-6.161$

0.000

Year of qualification

$-0.186$

0.032

$-5.784$

0.000

2.099

0.237

8.861

0.000

$-0.194$

0.199

$-0.975$

0.330

Constant

13.505

1.021

13.224

0.000

F-Statistic $=42.214,4 \mathrm{df}, p=0.000$

$\mathrm{R}^{2}=0.249$

Adjusted $\mathrm{R}^{2}=0.238$ 


\subsubsection{Auditors who did not advance to partnership}

In addition, it can be useful to analyse the auditors who did not advance to partnership with an audit firm. The analyses refer to differences between university-educated and non university-educated auditors. The variables of concern are the probability of becoming employed outside the audit profession, the percentage of auditors exiting audit practice, and their exiting velocity. During the 15-year period $44.2 \%$ (282 subjects) of the university-educated auditors had been employed outside the audit profession for some time. For NIVRA-educated auditors this was $30.5 \%$ ( 335 subjects).

Furthermore, it can be expected that auditors who do not have the possibility of advancing to partnership in an audit firm will leave the audit firm and seek employment outside the audit profession. This can certainly be expected if audit firms would use up-or-out promotion systems, which imply a up-topartner or out-of-the-firm promotion track [see, e.g. Gilson and Mnookin (1989)]. Therefore, the 667 auditors who did not advance to partnership were analysed. The results are shown in TABLE 11.

\section{TABLE 11}

Non-partners

\begin{tabular}{cccc}
\hline $\begin{array}{c}\text { Auditors who } \\
\text { did not }\end{array}$ & Education: & Inside or & Average time \\
progress to & University or & outside & before \\
partnership & NIVRA & the profession & exiting \\
\hline
\end{tabular}

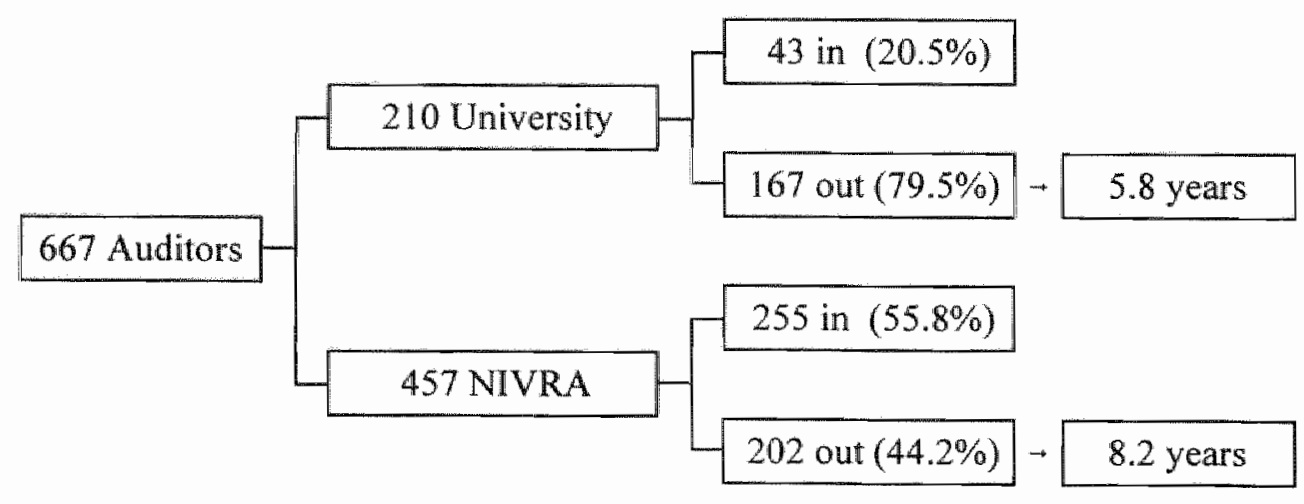


TABLE 11 indicates that university-educated non-partners are more likely to leave audit practice than the NIVRA-educated non-partners. Only $20.5 \%$ of the university-educated auditors who did not obtain a partnership with an audit firm remain employed in the audit profession in comparison with $55.8 \%$ of the NIVRA-educated auditors. The university-educated non-partners also have a higher exiting velocity. After qualification they remain with the audit firm for an average of 5.8 years before leaving audit practice, whereas NIVRA-educated auditors remain on average 8.2 years with the audit firm. Apparently, university graduates have more opportunities to become employed outside the audit profession than do NIVRA-educated auditors. The broader university education programme provides them with more opportunities to change employer as compared to the practically-oriented NIVRA programme, which has the advantage of the application of on-the-job knowledge.

Furthermore, a distinction between large and small audit firms indicates that auditors of small firms have a higher probability to remain with their firm as nonpartners than auditors of large firms. Of the 298 auditors who remain with an audit firm as non-partners, 186 are employed with a Big Six firm, while 112 auditors are employed with a non-Big Six firm. However, linking these results with the average numbers of auditors who where employed with Big Six and non-Big Six firms shows that the 186 non-partners account for only $15 \%$ of all employed auditors in Big Six firms. The 112 non-partners in non-Big Six firms account for about $40 \%$ of the employed auditors in non-Big Six firms. This finding shows that auditors of Big Six firms more frequently leave their firm if they cannot advance to partner, and provides preliminary evidence to the notion that larger audit firms more frequently use up-or-out promotion systems.

\subsection{Concluding remarks}

Previous research into the career advancement of auditors has tended to focus on differences between types of university education. This study examined differences in the career advancement of university and non university-educated auditors. The univariate results show that a university degree enhances the career possibilities of an auditor. Compared to NIVRA-educated auditors, university graduates advance more often to partnership. However, the multivariate analysis shows that the effect of education on the probability of achieving partnership is not statistically significant when allowing for the effect of age at qualification. The findings show that the main reason behind the better performance of universityeducated auditors than NIVRA-educated auditors on promotion to partnership is 
their more rapid advancement towards qualification as auditor. This finding contrasts with previous research since other studies were not able to establish essential differences at the partner level, or did not measure the effect of possible confounding variables such as age at qualification. The finding that university graduates have a higher promotion velocity agrees with previous research which also observed a positive relationship between additional academic education and promotion velocity.

The results further indicate that both audit firm size and change of audit firm are negatively related to the probability of achieving partnership. Also, audit firm size and change of audit firm are negatively related to promotion velocity. The higher promotion velocity within smaller firms contrasts with research suggesting accelerated promotion rates in larger firms serve as a means of protecting investments in human capital [Doeringer and Piore (1971)]. Furthermore, in contrast with human capital theory, auditors having a high study velocity do not have a higher promotion velocity. A possible explanation is that audit firms use age thresholds, requiring auditors to have a certain age before advancing to partnership, or indicating a maximum age at which auditors need to have achieved partnership.

An analysis of career advancement in Big Six audit firms reveals that the findings reported here also hold for a subsample of large international audit firms. In addition, it can be concluded that university-educated non-partners are more likely to leave audit firms than NIVRA-educated non-partners. The universityeducated non-partners also tend to leave the audit firm at an earlier stage. This may result from their more general education which enhances the opportunities for university graduates outside audit practice. Finally, the analyses show that the actual promotion probability for newly qualified auditors is $32 \%$ (partners vs. all auditors in the cohorts), and for auditors employed with audit firms, $51 \%$.

Since this study compares university with non-university education, the results are not completely comparable with previous research, but they are relevant for professional accountancy bodies having a non-university educational avenue or considering introducing such an avenue. At the same time, the findings with respect to the age at qualification will be of interest to audit firms and potential auditors. Since age at qualification is identified as a more important explanatory variable than education for advancement to partnership, future research is needed to ascertain the reasons for the importance of age at qualification. Perhaps (large) audit firms use some kind of age cap which prevents auditors qualifying at an above average age from advancing to partnership.

Furthermore, since the effect of education on the probability of achieving partnership seems to be driven by the young age at qualification of university 
graduates, the university curriculum is possibly structured in such a way that more students have the opportunity to qualify at a young age. Both university and NIVRA studies were of the same duration, but the combination of practical training and studies decreased the study velocity of NIVRA students. In this way, university education enhances the probabilities of advancing to partnership.

Moreover, it should be noted that data were obtained from secondary sources and that no data were obtained about the various staff levels at which auditors operated during the period of time between qualification and promotion to partnership. When these data are available future research can provide a more detailed view of the career differences between university-educated and non university-educated auditors.

Finally, the professional socialisation of students [Siegel, Blank and Rigsby (1991); Blank, Siegel and Rigsby (1991)], and personal characteristics of auditors, such as actual ability (IQ), personality and leadership [Crooks and Rock (1979)] can be expected to have a major influence on the auditor"s advancement. Since these characteristics may confound the relationship between the explanatory variables and career advancement, future research is needed to identify the effect of professional socialisation and personal characteristics on both the probability of achieving partnership and promotion velocity. 


\section{Chapter 3}

\section{Inter-organizational auditor mobility}

This chapter analyses the titer-organizationall nobility of tuditors. A model of inter-organizational mblility is examined including both personal and eiganuzational variables. Furtheimore by dislinguishing different types of moves. this study addresses auditing phenomena such as audit quality and auditor specializition from a nobility perspective. Even history analysis is used to take aecount of the time-dependence of the mobility process. Using longitudinal data on the inter organizational mobility of 13 innual coborts of entry tevel auditors in the Netherlands. lus cliapler shows lhat hin line with human capital theory the probability of auditor mobility decreases as auditors hecome nore specialized and develop nore ellentspecific liuman capital furthermore, evidence is provided on the quality difference between Big six and nion BIg six audit

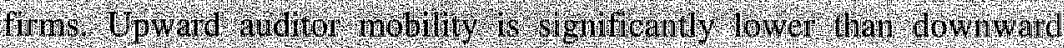
audicor nobility Mrededer, he results indicate hat up or out pronotion systems are used in audit inims but nainly at Big Six fimins. Transition bate nodels further show that there is an inverse relationship between career nobility and jobtenure. work experience, advancenent to parnership, and the founding of an audit lim by an auditor. The probubily of aiditor mobility increases with education and year of qualification

\subsection{Introduction}

Audit firms are service organizations whose most dominant input is human capital [Gilson and Mnookin (1989)]. Therefore, the selection, training, and retention of auditors is a crucial part of an audit firm's operations. And while selection and training decisions are controllable by audit firms, the outcome of retention efforts is uncertain resulting in concerns expressed by audit firms about too high levels of 
employee mobility in audit firms [see, e.g. Rhode, Sorensen and Lawler (1977); Dillard and Ferris (1979); and Bullen and Flamboltz (1985)]. Hence, auditor mobility is generally viewed as a dysfunctional element in audit firms because of increased recruiting and training costs, complications and uncertainties in planning audits, and possible decreases in client goodwill if the auditors assigned to a client change too frequently. However, Waller (1985) also perceives benefits associated with auditor mobility. These include the disposition of less productive auditors, lexibility in maintaining the optimal size of labour forces, and possible increases in client goodwill if 'loyal' auditors move to (prospective) client positions. Acknowledging the auditor mobility phenomenon, Waller (1985) justifies research on mobility as follows:

In the light of these costs and benefits, turnover (mobility) should not be viewed as a problem to be eliminated but as a phenomenon to be understood and, to the extent possible, controlled so that firms can approach an optimal balance between the costs and benefits."

Until now, only parts of the mobility phenomenon have been examined. Most previous studies on inter-organizational mobility of auditors concentrated on the influence of individual attitudes of auditors on turnover intentions and their principal justification for studying auditor mobility was to control and influence auditor behaviour in order to maximize audit firm profits [for overviews see Dillard and Ferris (1989); and Gregson (1992)].

However, from recent behavioural studies it appears that the association between individual attitudes and turnover intentions is overstated [Dalton and Mesch (1990); Dalton (1995)] and it can be questioned whether intent to turnover is an adequate surrogate for actual turnover behaviour [Tett and Meyer (1993)]. Furthermore, from studies in social and organizational career mobility it appears that organizational variables such as firm-size and type of firm are important variables in explaining mobility [see for overviews, e.g. Nystrom and McArthur (1989); and Dalton and Todor (1993)], and that the nature of an interorganizational move is an important factor in the mobility process [Rosenfeld (1992)].

This certainly holds in the context of audit firms. It can be argued that, on average, auditors at large firms have larger and therefore fewer clients as compared to auditors at small firms. This implies a higher degree of specialization

\footnotetext{
'Employee turnover can be defined as leaving the current employment position. Accordingly, mrnover refers to intra- as well as inter-organizational mobility. Nevertheless, most studies on auditor turnover use this term to indicate the migration of auditors to other firms, which is referred to in this study as inter-organizational mobility or mobility.
} 
resulting in a higher level of client-specific rents [see, e.g. DeAngelo (1981b)]. These rents are the result of an auditor's knowledge of a specific client, and because departing auditors cannot take these large clients with them, their clientspecific knowledge is 'tied' to the audit firm. Hence, these client-specific rents become firm-specific capital [see Gilson and Mnookin (1985)]. Consistent with human capital theory, auditors with more firm-specific human capital have less propensity to move than those with less firm-specific human capital [see, e.g. Becker (1964); and Mincer (1974)]. Accordingly, the nature of the firm is relevant in explaining auditor mobility. Therefore, this study introduces organizational variables to distinguish between different types of mobility, enabling the examination of client-specific investments from a mobility perspective.

Besides the issue of client-specific investments, the distinction between different types of mobility enables the examination of another "traditional" issue in auditing: audit quality. While quality differences between large and small audit firms thave been researched from various perspectives, audit quality has never been addressed from an auditor mobility perspective. ${ }^{2}$ However, the suggestion that the audit market is segmented, and that different qualities are offered in this market, can be expected to be reflected in the mobility patterns of auditors. Because human capital is the dominant production factor in auditing, quality differences between audit firms will also be reflected in the abilities and audit skills of individual auditors. This implies that auditors of large firms are expected to move easier to small firms than small firm auditors move to large firms.

However, in this respect, but also in the analysis of client-specific investments, up-or-out promotion systems seem to play a prominent role. Up-orout rules are frequently used in professional service firms [see Gilson and Mnookin (1989)], and create downward mobility. This might confound the results on audit quality, which operate in a similar direction, but also on client-specific investments, if there is a difference in the use of up-or-out rules between large and small firms. ${ }^{3}$ Therefore, the practice of up-or-out promotion systems will also be investigated to separate its effect on auditor mobility from those of client-specific investments and audit quality.

\footnotetext{
${ }^{2}$ See chapter 1 for an overwiew on different approaches in audit quality research.
}

${ }^{3}$ For example, if large audit firms more frequently use up-or-out systems as compared with small firms, there will be an additional outflow of auditors from large firms due to negative promotion decisions. This contradicts with the prediction that auditors of large firms, because of a higher degree of client-specific investments, have a lower propensity to move than auditors of small firms. 
In addition to neglecting actual turnover and organizational variables to distinguish between different types of mobility, previous studies on interorganizational mobility of auditors used a static approach, i.e. measuring the influence of personal attitudes on a single turnover decision. However, career mobility is a dynamic process where variables change over time and where auditors can have more inter-organizational moves during their career. Therefore, in this study the mobility process is analysed by means of event history analysis, where statistical methods are used to analyse time intervals between successive career events. Compared to traditional time-series analyses, event histories are often better suited to the dynamic character of empirical phenomena [Blossfeld and Rohwer (1995)].

Hence the contribution of this study is threefold. First, it examines auditor mobility by assessing the influence of organizational variables, in addition to personal variables, on actual auditor mobility. Second, it addresses 'traditional' auditing issues from an auditor mobility perspective. Third, it uses event history analysis to study the process of auditor mobility.

The results of this study are not only relevant for those who are (considering) pursuing a career in auditing, and for those who are concerned with the planning and management of human resources within audit firms, but also for research regarding audit quality and client-specific investments. Finally, labour is the most important production factor in auditing. Audit services are produced and provided by (groups of) individuals. Hence, accounting labour markets are in itself an interesting subject for auditing research.

The empirical analyses are based on observations of the career mobility of thirteen annual cohorts of entry-level accountants in The Netherlands who received their license in the thirteen-year period between January 1970 and December 1982. Their careers are analysed within the period 1970-1998. The main data sources used are the professional journal and membership lists of the Dutch professional body of accountants, the Royal Dutch Institute of Registered Accountants. The results of this study suggest that auditor mobility decreases as auditors develop more client-specific human capital. Evidence is also provided on the effect of quality differences between Big Six and non-Big Six audit firms. Upward auditor mobility (from small to large firms) is significantly lower than downward auditor mobility (large to small firms). Furthermore, evidence is provided on the use of up-or-out promotion systems by the Big Six audit firms. Non-Big Six audit firms are not found to use up-or-out rules. Moreover, transition rate models show that there is an inverse relationship between job-tenure, work experience, advancement to partnership, and the founding of an audit firm by an 
auditor, and career mobility. The probability of auditor mobility increases with education and year of qualification.

The chapter proceeds as follows. The next section discusses previous research on inter-organizational auditor mobility. Then hypotheses on human capital and auditor mobility are developed. The fourth section describes the research methodology, and section five gives the results of the study. The chapter concludes with a discussion of the results and implications for future research.

\subsection{Previous research}

There is a rich and longstanding tradition of research in organizational studies examining employee mobility. ${ }^{4}$ This research area addresses a wide range of variables affecting mobility in many different work environments (i.e. manufacturing, government, service firms), and different labour relations (i.e. workers, technicians, academics), using a large variety of theoretical constructs [see, e.g. Vardi (1980); and Rosenfeld (1992)]. In contrast, research on auditor mobility has focussed almost exclusively on the effect of personal attitudes on the intent to turnover. ${ }^{5}$ A general conclusion of these studies is that satisfaction and motivation are good predictors of turnover intentions. The primary motivation of these auditor mobility studies was to gain control over the turnover problem in audit firms.

One of the first signals of turnover problems in audit firms was the establishment of a subcommittee on staff retention by the American Institute of Certified Public Accountants (AICPA) [Leathers (1970)]. This led to a multi-year study, funded by the AICPA and several large audit firms, on the turnover problem in public accounting (see hereafter). Hellriegel and White (1973) were the first to address the turnover problem in academic research. They conducted a survey among US auditors to compare the perceptions of non-turnover auditors and turnover auditors with respect to their (previous) audit firm. Hellriegel and White (1973) found that dissatisfaction with performance evaluations, work climate, career advancement, prestige of the job, lack of security in the job, and increased compensation at the new employer were the principal factors inducing

\footnotetext{
${ }^{4}$ For overwiews on employee turnover, see, e.g. Mobley, Griffeth, Hand and Meglino (1979), Steel and Ovalle (1984), Cotton and Tuttle (1986) and Dalton and Todor (1993).

${ }^{5}$ For overviews on auditor turnover, see Dillard and Ferris (1989) and Gregson (1992).
} 
turnover. Furthermore, organizational and personal factors such as firm-size, age and education were not found to influence the turnover decision.

The first results on auditor turnover of the previously mentioned multi-year study on professional staff turnover in US audit firms were reported by Rhode, Sorensen and Lawler (1976). ${ }^{6}$ By comparing turnover and non-turnover auditors they determined personal characteristics inducing turnover. Rhode, Sorensen and Lawler (1976) found eight variables to be closely linked with turnover: universities attended, university grade-point average, number of extra curricular activities, religion, father's education, father's occupation, mother's occupation, and parents" income.

In a subsequent study, Rhode, Sorensen and Lawler (1977) examined 92 actual turnovers to identify sources of professional staff turnover in audit firms. On 39 selected reasons (these were all job characteristics) for leaving the audit firm, auditors and audit firms were asked to rate the importance on the turnover decision. Furthermore, a distinction was made between voluntary and involuntary turnovers. The results show that the importance ratings of the reasons for turnover were not different for auditors and audit firms, and for voluntary and involuntary turnovers. The most important reasons for turnover were the heavy work load, the inability to satisfy the conflicting demands of supervisors and the inability to use possessed skills and abilities. According to Rhode, Sorensen and Lawler (1977) the major cause of the turnover problem is the expectation gap of entry-level auditors with respect to the content of the job and not the dissatisfaction with performance evaluations.

Thereafter, several studies examined the influence of auditor motivational and attitudinal factors on turnover intentions [see, e.g. Dillard (1979); Dillard and Ferris (1979); Benke and Rhode (1980); Senatra (1980); Aranya, Lachman and Amernic (1982); Aranya and Ferris (1984); and Bullen and Flamholtz (1985)]. In general, these studies show that job satisfaction is a dominant factor in explaining turnover intentions [Dillard (1979); Benke and Rhode (1980); Aranya and Ferris (1984); and Bullen and Flamholtz (1985)], but also organizational commitment was found to be an important factor [Aranya, Lachman and Amernic (1982)]. Dillard and Ferris (1979) conclude that personal attitudes influence turnover, but

\footnotetext{
"This study was sponsored by the AICPA and several large US audit firms to identify the factors influencing tumover by systematically examining various characteristics and attitudes of individuals who entered public accounting. Other reports from this study examined the generation gap in attitudes between entry-level and experienced employees in audit firms [Sorensen, Rhode and Lawler (1973)], and the job choice and post-decision dissonance of auditors [Lawler, Kuleck, Rhode and Sorensen (1975)].
} 
identified no dominant factor. Senatra (1980) and Aranya, Lachman and Amernic (1982) found no association between job satisfaction and intended turnover.

Arnold and Feldman (1982) extended this line of research not only by using a broader range of variables to explain turnover intentions, but also by investigating whether the intention to turnover is associated with actual turnover. Their analysis included demographic variables (such as age, gender and marital status), tenure, job satisfaction and organizational commitment, perceived job security and perceived existence of alternative employment positions to investigate turnover intentions and actual turnover. Arnold and Feldman (1982) conclude that age, job satisfaction and organizational commitment influence the intention to leave, and that intention to leave together with tenure and perceived job security explain actual turnover.

A different approach to the turnover problem in public accounting was taken by Waller (1985), who investigated the use of different employment contracts to influence turnover behaviour. Using an experiment, Waller (1985) shows that by carefully determining the terms of the employment contract offered to newly hired auditors, audit firms are able to attract auditors with a low probability of turnover in the first years of their employment with the firm. However, individual auditor characteristics were not modelled in this study.

Whereas several studies continued to address the influence of job satisfaction and organizational commitment on turnover intentions or actual turnover [see, e.g. Harrell, Chewning and Taylor (1986); Lachman and Aranya (1986); Colarelli, Dean and Konstans (1987); Dean, Ferris and Konstans (1988); Gregson (1990); Harrell (1990); Bline, Duchon and Meixner (1991); and Snead and Harrell (1991)], a major contribution to the existing research on auditor mobility was made by Sheridan (1992) and Barkman, Sheridan and Peters (1992). Both studies used survival analysis to examine the effect of cultural values on voluntary employee turnover in auditing. This technique provides estimates of survival and hazard rates of newly-hired auditors. The survival rate function describes the probability of not having an event as a function of time and the hazard rate function describes the probability of leaving a particular state. Hence, the effect of time on the probability of turnover is taken into account. Sheridan (1992) provides evidence that organizational culture values (e.g. interpersonal relationship values) strongly affect the retention rates of auditors in the early career stages. Moreover, Barkman, Sheridan and Peters (1992) developed and tested survival models of professional staff retention in audit firms to assess the costs of turnover during each month of seniority. They conclude that especially in the early career stages replacement costs of auditors increase with seniority. In a more recent study, Hunton and Wier (1996) used survival analysis to study career 
advancement and turnover of accountants in private industry. With respect to turnover, they conclude that education is positively related to turnover. However, they only observed the first five career years.

Recent studies still address the influence job satisfaction and organizational commitment on turnover, but in different settings [Maupin and Lehman (1994); and Quarles (1994)]. Also, studies investigated the effect of gender on the intent to turnover [Reed, Kratchman and Strawser (1994)] or on actual turnover [Dalton, Hill and Ramsay (1997a)]. Furthermore, Dalton, Hill and Ramsay (1997b) provide evidence on the effect of litigation on actual turnover. However, none of these studies used survival analysis.

All in all, there is ample research on the association between personal attitudes and auditor turnover. However, little is known about other factors associated with auditor mobility. Furthermore, although from an audit firm's perspective it is certainly important to study why auditors leave a particular firm, careers consist of sequences of jobs and to understand career processes fully, one also needs to consider the nature and the timing of the underlying career moves [Rosenfeld (1992)]. In other disciplines like organizational studies and labour economics, employee mobility is addressed by: (1) using a wide range of variables; (2) by studying various types of inter-organizational moves; and (3) by using advanced statistical techniques to assess the timing of career moves. These three aspects are described hereafter.

Organizational variables have appeared to be important in explaining employee mobility. ${ }^{7}$ For example, organizational size [see, e.g. Carroll and Mayer (1986); Greve (1994)], up-or-out systems [Malos and Campion (1995)], and job ladders [Baron and Bielby (1980)] have been shown to be strongly related to mobility. Also, in their literature review on individual behaviour of auditors, Dillard and Ferris (1989) observed the need for including organizational variables in mobility studies. Hence, this study uses personal as well as organizational variables to analyse inter-organizational auditor mobility.

Moreover, previous studies on auditor mobility focussed on single turnover decisions, and did not examine the nature of moves. Rosenfeld (1992) argues that studying complete work histories and the nature of the underlying moves adds substantially to our knowledge of work histories and careers. In the context of audit firms, this certainly applies. Human capitall plays an important role and the nature of the firm largely determines the degree of firm-specific human capital

\footnotetext{
${ }^{7}$ For an elaborate overview of organizational variables and their influence on careers, see Nystrom and McArthur (1989).
} 
possessed by auditors. That is, auditor-client relationships create firm-specific capital [Gilson and Mnookin (1985)] and according to human capital theory, mobility is negatively associated with firm-specific human capital [see, e.g. Becker (1964); Mincer (1974)]. Also, models of firm-specific capital [Jovanovic (1979b); Hashimoto (1981)] emphasize the importance of firm-specific human capital in the analysis of inter-firm labour mobility. Accordingly, the nature of the firm is certainly relevant in explaining auditor mobility. Several, mostly recent, organizational and labour economics studies analysed inter-organizational mobility. Relevant for this study are contributions by, for example Smith (1983), Stewman and Konda (1983), Wholey (1985), Shaw (1987), Sicherman and Galor (1990), Topel and Ward (1992), Farber (1994), Spurr and Sueyoshi (1994) and Haveman (1995). These studies generally examined inter-organizational mobility using more or less complete work histories. Wholey (1985) and Spurr and Sueyoshi (1994) applied their analysis to law firms, which makes their contributions comparable to a study of inter-organizational auditor mobility. Wholey (1985) found that lateral entry into law firms only occurs in the early career stages and employees who do not become partners leave the firm and move to smaller law firms or corporations, or become sole practitioner. Spurr and Sueyoshi (1994) observe that lawyers either become partner or leave the firm indicating an up-or-out system.

Furthermore, except for Sheridan (1992), Barkman, Sheridan and Peters (1992), and Hunton and Wier (1996) previous studies on auditor mobility have used static research methods such as logistic regression analysis and regression analysis with dummy variables. However, inter-organizational mobility is a dynamic process, dependent on explanatory variables changing over time. Therefore, it is important not only to know whether inter-organizational moves took place, but also exactly when they occurred [Morita, Lee and Mowday (1989)]. Moreover, the aforementioned research methods are not appropriate when many individuals do not experience inter-organizational mobility [see, e.g. Petersen (1991)]. These problems can be solved by using event history analysis, which accounts for time-varying explanatory variables and subjects who do not experience the event under study (right censored subjects). Several studies in the organizational literature have used event history analysis in mobility studies [see, e.g. Morita, Lee and Mowday (1989, 1993); Greve (1994); and Farber (1994). However, their results do not apply to auditor mobility.

None of the previous organizational or labour market studies provides evidence on the influence of both individual and organizational variables on the probability of inter-organizational mobility in professional service firms. Furthermore, the 
moderating effect of time has not been taken into consideration. Therefore, this study is the first to combine these topics in one study.

Moreover, with respect to audit quality, client-specific investments, and upor-out promotion systems, there has been no study to date which examined these issues from an auditor mobility perspective. Empirical studies addressing audit quality have shown that large firms provide a higher audit quality as compared to smaller firms. According to Yardley, Kauffman, Cairney and Albrecht (1992) the following aspects of audit quality differences have been investigated: industry expertise as an indicator of better evidence-gathering ability [see, e.g. Danos and Eichenseher (1982)], litigation records as indicators of audit failures [Palmrose (1988)], and opinion shopping as an indicator of resisting client-pressure [Levinthal and Fichman (1988)]. Furthermore, studies have been conducted on the existence of a large firm fee premium for Big Six audit firms, indicating a higher audit quality [see, e.g. Palmrose (1986)]. Also, studies have demonstrated quality differences between large and small audit firms by analysing stock market reactions of companies changing to smaller audit firms [Eichenseher, Hagigi and Shiells (1989)], or by examining review findings in audit files to measure the actual detection of errors [Deis and Giroux (1992)]. However, these studies regard audit firms as single entities and do not consider audit quality differences at the level of individual auditors, although it can be argued that the quality of an audit firm largely depends on the quality of its auditors.

Client-specific investments have been dealt with by studies on industry specialization. Two explanations are given in the auditing literature for industry specialization. The first one is that some audit firms produce quality differentiated audit services and that their reputation for supplying superior quality explains their industry dominance [see, e.g Dopuch and Simunic (1980); DeAngelo (1981b)]. The other explanation is that economies of scale in the production of audit services cause industry dominance [see, e.g. Eichenseher and Danos (1981)]. Previous studies on industry specialization generally examined auditor concentrations across different industries and they provide evidence of industry specialization by audit firms [see, e.g. Eichenseher and Danos (1981); Craswell, Francis and Taylor (1995)]. However, these studies do not address the production of audit services at the level of individual auditors. Hence, the current study analyses client-specific investments from the perspective of individual auditors by examining their probability to move given different Jevels of industry specialization. Furthermore, empirical studies on the use of up-or-out promotion systems in audit firms have not been undertaken. Accordingly, the analysis of these three issues from a mobility perspective leads to a fuller understanding of these phenomena. 


\subsection{Hypothesis development}

\subsubsection{Introduction}

This study focuses on several aspects of inter-organizational auditor mobility. First, hypotheses will be tested with respect to a model of total interorganizational auditor mobility. This general model only distinguishes one type of transition: inter-organizational moves, irrespective of the nature of the move (i.e. transitions from one employer to another). This will provide insight in the total inter-organizational mobility of auditors. Hypotheses are developed regarding the influence of audit firm size and several personal variables on auditor mobility, and on the timing of auditor mobility. After that, specific tests of inter-organizational auditor mobility will be conducted by considering the nature of interorganizational moves. These specific tests distinguish different types of transitions (i.e. transitions among large audit firms, small audit firms and business firms/government). Hence, hypotheses will be tested with respect to (1) up-or-out promotion systems and inter-organizational auditor mobility, (2) client-specific investments and inter-organizational auditor mobility and (3) quality differences between audit firms and inter-organizational auditor mobility.

\subsubsection{A general model of inter-organizational auditor mobility}

\subsubsection{Audit firm size and inter-organizational auditor mobility ${ }^{8}$}

Regarding the relationship between audit firm size and inter-organizational auditor mobility, several arguments can be advanced. These arguments relate to clientspecific investments, audit quality, and up-or-out promotion systems. Each argument will be discussed separately, after which the hypothesis on audit firm size and inter-organizational auditor mobility will be formulated.

\section{Client-specific investments}

Audits are performed by individuals and therefore human capital plays an important role in audit firms. Both audit firms and auditors are required to make substantial investments in human capital (i.e. by schooling, on-the-job training). According to human capital theory, human capital can take two forms: general human capital and firm-specific human capital [Becker (1964)]. General human

\footnotetext{
${ }^{8}$ Some of the ideas on audit quality and client-specific investments were introduced in a 1993 MARC Research Memorandum by Maijoor and Meuwissen.
} 
capital is effective in raising productivity at the current firm, but also at other firms. Firm-specific human capital makes employees more productive at the current firm, but has no effect on productivity elsewhere. Consequently, general human capital is easily transferable between employers, whereas the transferability of firm-specific human capital is limited. Hence, the existence of firm-specific human capital is expected to affect the inter-organizational mobility of auditors.?

Auditors acquire general as well as firm-specific human capital. They acquire general human capital mainly through audit education and general on-thejob training. This is for example general knowledge on the planning of audits, and on how to perform analytical reviews. Firm-specific human capital is acquired if auditors possess specific knowledge of clients. This argument is advanced by Gilson and Mnookin (1985) who argued that clients are a source of firm-specific capital in professional service firms because of the existence of client-specific investments. Auditors invest in client-specific information to become familiar with the client and its business to provide the demanded audit services. Hence, there are significant start-up costs associated with servicing audit clients [see, e.g. DeAngelo (1981a)]. These investments vary with the size of the client and the degree of industry specialization. Client-specific investments are higher for large clients than for small clients, because of the larger scale of operations and wider and more specialistic range of business and corporate matters. Audit firms use industry specialization as a means to decrease the amount of start-up costs associated with servicing clients. For auditors, however, industry specialization leads to more specific investments in client relationships. If it is assumed that individual auditors cannot take clients with them when leaving the audit firm, their client-specific investments are tied to the firm and become firm-specific capital. Therefore, auditors with a high degree of client-specific investments are expected to be tied to their firm and have a lower probability to move.

And in this respect, there is a difference between large (Big Six) and small (non-Big Six) audit firms. Large firms have a higher degree of specialization than small firms. Auditors of large (Big Six) audit firms usually service a small number of large clients, which requires a large amount of in-depth client-specific knowledge. This process has been intensified when large audit firms started to stimulate industry specialization and set up practice units which only serve certain types of clients [see, e.g. International Accounting Bulletin (1993a, 1993b)]. Furthermore, aneedotical evidence indicates that the lead auditors in Big Six

\footnotetext{
Models of firm-specific capital emphasize the importance of firm-specific human capital in the analysis of inter-firm labour mobility [Jovanovic (1979b); and Hashimoto (1981)].
} 
firms, responsible for the audit of large multinational clients, are almost fully engaged with one or a few large clients. In contrast, auditors of small (non-Big Six) audit firms, with more generic practices, usually service a large porffolio of small clients requiring more general audit and accounting knowledge. This difference results in a higher degree of firm-specific capital of auditors of large firms as compared to small firms. And, consistent with human capital theory, auditors with more firm-specific human capital have less propensity to move than those with less firm-specific human capital [Becker (1964)]. Therefore, from a client-specific investment perspective, it can be expected that inter-organizational auditor mobility from large (Big Six) audit firms is lower than inter-organizational auditor mobility from small (non-Big Six) audit firms.

\section{Audit quality}

It is frequently suggested that the audit market is segmented and that different qualities of audit services are offered [see, e.g. DeAngelo (1981 b); and Palmrose (1986)]. Because human capital is the main production factor in auditing, skill differences can be expected between auditors of firms offering different audit qualities. Skills acquired by auditors might not be transferable to other firms offering a different level of audit quality. Nevertheless, if there is mobility between different quality levels, it should be downward mobility to lower quality firms. This can be explained from a human capital perspective.

Auditors from high quality audit firms, as compared to lower quality firms, generally possess higher quality skills, merely because they received higher quality on-the-job training. Furthermore, they can be expected to possess higher abilities because high quality firms will attract the best and brightest individuals. According to human capital theory, on-the-job training and ability are important variables for explaining earnings differences and job opportunities [see Becker (1964); Mincer (1974)]. Hence, auditors of higher quality firms have more opportunities to obtain an employment position outside their current audit firm than auditors from low quality firms.

The frequently suggested quality segmentation of the audit market between large (Big Six) audit firms and small (non-Big Six) audit firms [see, for example Francis (1984)] can be examined by analysing the inter-organizational mobility of auditors. That is, the large firms provide high quality services to large auditees, are internationally oriented, and use standardized audit programmes, whereas the smaller firms provide lower quality services to smaller auditees, are more nationally oriented, and have other services like bookkeeping, tax and consulting as important parts of their activities. These quality differences are expected to result in higher downward mobility from high quality firms to low quality firms, 
than upward mobility. Furthermore, auditors from high quality firms more easily obtain employment positions in business/government than auditors from low quality firms. Hence, from an audit quality perspective it can be expected that inter-organizational auditor mobility is higher for auditors from large (Big Six) audit firms than for auditors from small (non-Big Six) audit firms.

\section{Up-or-out promotion systems}

The employment practice of professional service organizations, such as audit firms, law firms and consulting firms, has been dominated by the up-or-out promotion system [see Gilson and Mnookin (1989)]. Over an apprenticeship period of up to approximately ten years associates progress towards a decision regarding their admission to partnership. Associates who are promoted to partner can expect a permanent career with the firm and remain partner until retirement. Associates who are not promoted to partner will have to leave the firm and seek an employment position elsewhere. Accordingly, these up-to-partner or out-of-thefirm promotion tracks create inter-organizational mobility to other firms, corporate clients or other business firms. Hence, employees from firms with up-or-out promotion systems will have a higher probability of inter-organizational mobility.

At first, the up-or-out system seems to be an odd system from an economic perspective. The system forces firms to dismiss associates who do not meet the partnership criteria, but who may be productive and profitable at the associate level. However, three explanations can be advanced why firms engage in up-orout promotion systems. First, up-or-out systems protect associates against firms behaving opportunistically by not promoting associates who meet the partnership criteria. The firm is forced to make a partnership decision and cannot retain individuals who satisfy the standards for promotion as associates [see Gilson and Mnookin (1989)]. Second, they reduce the firms' uncertainty on selecting the best and brightest associates for partnership. The apprenticeship period enables the firms to monitor associates to determine whether they meet the partnership criteria [see Gilson and Mnookin (1989)]. Third, up-or-out systems raise the quality of the work force because associates who do not satisfy the partnership criteria are dismissed. This leads to more terminations because it raises the promotion standards associates must exceed in order to be retained, i.e. only few become partner [see Lazear (1998)].

While most research on this topic focussed on law firms [see, e.g. Wholey (1985); Gilson and Mnookin (1989); Malos and Campion (1995)], audit firms also adopted up-or-out promotion policies. However, it can be expected that there is a difference between large and small audit firms regarding the use of up-or-out rules. Small firms have less incentives to use up-or-out promotion policies. First, 
they have less opportunities to promote associates since they only possess a small number of partner positions. Also, when associates have to leave the firm since they were denied partnership, staffing problems may arise due to the small number of associates. To make the up-or-out system function effectively, there needs to be a pool of associates and a reasonable number of partner positions of which some become vacant regularly. Otherwise the system becomes too costly. Hence, larger firms have better opportunities to adopt up-or-out promotion systems. Furthermore, empirical evidence from the study on auditor career advancement (see chapter 2) indicates that large audit firms more frequently use up-or-out systems as compared with small audit firms. Considering the fact that up-or-out promotion systems increase inter-organizational mobility, it can be expected that, from an up-or-out perspective, inter-organizational auditor mobility from large (Big Six) audit firms will be higher than inter-organizational auditor mobility from small (non-Big Six) audit firms.

Each of the arguments advanced above predict a relationship between audit firm size and total inter-organizational mobility. The three explanations, however, predict different effects of firm size on auditor mobility. Two of the explanations, audit quality differences and up-or-out promotion systems, predict a positive relationship between audit firm size and the probability of inter-organizational mobility. The client-specific investment explanation, in contrast, predicts a negative relationship: auditors of large audit firms will have a lower mobility rate as compared to auditors of small audit firms. Based on these conflicting arguments, it remains unclear which of the three effects will have the most influence on the relationship between audit firm size and total inter-organizational mobility. Therefore, without a prediction of the sign of the total effect, it is hypothesized that:

$\mathrm{H}_{1}$ Audit firm size is related to total inter-organizational auditor mobility.

\subsubsection{Personal variables and inter-organizational auditor mobility}

Among the most common factors used to explain inter-organizational mobility, education has been found to increase the ease of turnover [see Cotton and Tuttle (1986)]. Human capital theory argues that education is an investment in human capital and this investment is made with the expectation that it will produce higher income. Higher income is attained because a more educated human asset is more productive and valuable than a less educated one. In the context of auditing, this is set out as follows. Auditors can qualify through a non-university education 
programme or through a university education programme. The non-university programme is practically-oriented since students combine audit work with studies during their education. The advantage of this programme is the application of knowledge on-the-job. In contrast, university-educated auditors possess less practical experience but their education is regarded as broader, which provides them with additional skills and capabilities not generally possessed by those who have followed non-university education. Hence, university education provides auditors with more opportunities to change jobs, giving them a greater probability of mobility. So it can be expected that:

$\mathrm{H}_{2}$ The probability of inter-organizational auditor mobility increases with education.

Age is also considered an important variable in the analysis of inter-organizational mobility. It has been found to be negatively related to auditor mobility [see, e.g. Arnold and Feldman (1982)]. Similar to work experience, auditors who qualify at a higher age have a shorter time over which the benefits of a better match have to outweigh the costs of the move. Furthermore, they will have more experience because of their longer training period. During this period, they might already have attained better job-matches. It can, therefore, be hypothesized that:

$\mathrm{H}_{3}$ The probability of inter-organizational auditor mobility decreases with a higher age at qualification.

A partnership is considered to be the ultimate success in public accounting. When auditors have achieved a partnership position, there are only very few jobs with higher rewards. Only partnerships with larger audit firms or high management positions outside the audit profession will be considered as such. So, matching theories of employee mobility [see, e.g. Jovanovic (1979a); Borland and Lye (1996)] imply that partners will observe that they are well-matched, and their probability to move will decrease. Therefore, from a matching perspective it can be expected that:

$\mathrm{H}_{4}$ The probability of inter-organizational auditor mobility decreases with a promotion to partnership.

In auditing the labour market is closely related to the product market. Auditors who cannot become partner with an audit firm, might decide to start their own firm. And if auditors found an audit firm, they will be committed to make their new business a success. Their organizational commitment will be high. Previous studies on auditor mobility have shown that organizational commitment is 
negatively related to mobility [see, e.g. Arnold and Feldman (1982); Colarelli, Dean, and Konstans (1987)]. Therefore, the following hypothesis should hold:

$\mathrm{H}_{5}$ The probability of inter-organizational auditor mobility decreases when the auditor is firm founder.

This research undertakes a longitudinal analysis of auditor mobility. It analyses the mobility of auditors who entered the auditing profession at different points in time. Yet, chapter 4 on competition in audit markets indicates that competition increased over time. Furthermore, since human capital is the dominant production factor in audit firms, competition in the audit market is closely associated with individual career decisions [see, e.g. DeFond and Park (1999) on competition and CEO turnover). Hence, it can be argued that the labour market might have changed because of changes in the competitiveness of the audit market. Especially in the nineteen-eighties, regulatory changes (i.e. the introduction of the Fourth EU Directive) affected the mobility of auditors. ${ }^{10}$ Since competition increased over time, these effects will be more profound for later cohorts of auditors. Hence, it can be hypothesised that:

$\mathrm{H}_{6}$ The probability of inter-organizational auditor mobility will be higher for later cohorts than for earlier cohorts.

Several studies indicate that there are consistent differences in the rates of employee mobility between individuals [see, e.g. Greve (1994)]. Some individuals have a greater propensity to move than others. Considering the fact that individuals who moved have a low job tenure in their new job, human capital and matching theories predict that individuals with low job tenure have a greater probability to leave the organization. So, auditors who moved are more likely to move again. Therefore, it is useful to control for the number of previously held jobs by auditors. This leads to the following hypothesis:

$\mathrm{H}_{7}$ The probability of inter-organizational auditor mobility will be higher for auditors with a higher number of previously held jobs.

I* The fourth EU Directive required medium-sized companies to have their annual accounts audited. Hence, it can be expected that this directive increased the demand for audit services, as can be seen by the substantial increase in the entry of audit firms "see chapter 4]. And the entry of an audit firms is actually the result of individual career decisions of auditors. 


\subsubsection{The timing of inter-organizational auditor mobility}

While previous studies on auditor mobility concentrated on the effects of personal attitudes on single turnover decisions (i.e. a static approach), it needs to be recognized that inter-organizational mobility is a dynamic process where timing [see, e.g. Rosenfeld (1992)] is important. Therefore, two hypotheses are developed regarding the timing of auditor mobility.

The general theory of human capital accumulation, which was developed primarily to interpret career earnings profiles, applies to the acquisition of skills [see, e.g. Becker (1964); and Mincer (1974)]. The theory has been related to observable measures of human capital investments, most notably schooling and on-the-job training. With respect to these investments, human capital theory posits that longer job-tenure (experience in a particular job) should be translated into greater employee value and productivity as a result of greater job-specific human capital. Hence, job-tenure is, through job-specific human capital, negatively related to mobility. This was also found by previous studies on auditor mobility [see, e.g. Arnold and Feldman (1982); Sheridan (1992)].

Yet, the decline in employee mobility with job-tenure can also be predicted from a matching perspective (see, e.g. Jovanovic (1979a); Rosenfeld (1992); Borland and Lye (1996)]. Matching theories of worker mobility posit that individuals search for optimal job-matches and learn about the quality of the match through experience in that match. Consequently, poor job matches are more likely to end early. This process gradually refines the set of job matches until the best matches remain. And from this matching perspective it is possible to advance a more accurate prediction of mobility over time. Models of labour market matching predict the process of auditor mobility as follows [see Jovanovic (1979a); and Borland and Lye (1996)]. At first, new information of the new employment relationship will be valued and during this process there will be a low rate of inter-organizational auditor mobility. Thereafter, when auditors have valued the information about their new employer, separation will occur because of better opportunities elsewhere. As tenure increases, the best employee-firm matches remain, and it becomes more unlikely that these employees will find better opportunities elsewhere. So, the rate of inter-organizational auditor mobility will decrease. These arguments imply that:

$\mathrm{H}_{8}$ The probability of inter-organizational auditor mobility initially increases and then decreases with years of job tenure.

Not only the experience in a particular job (job tenure) but also work experience (total time in the labour market) is related to employee mobility. Work experience 
has been found to decrease the probability of inter-organizational mobility [see, e.g. Rosenfeld (1992)]. According to matching theories this reflects a decreasing discrepancy between the current match and the optimal job-match as employees constantly search for a better match. Furthermore, it is associated with the shorter time more experienced employees remain in the work force. They have a shorter time over which they will enjoy the benefits of a better match, and then it often does not outweigh the costs of mobility between the two matches. As with jobtenure, at the start of the career a waiting time is expected. Hence, it can be hypothesized that:

$\mathrm{H}_{9}$ The probability of inter-organizational auditor mobility initially increases and then decreases with years of work experience.

\subsubsection{Specific tests of inter-organizational auditor mobility}

\subsubsection{Up-or-out promotion systems and inter-organizational auditor mobility}

The discussion on the effect of audit firm size on inter-organizational auditor mobility (see paragraph 3.3.2.1) pointed out that up-or-out promotion systems create inter-organizational mobility. Furthermore, it was suggested that small audit firms have less incentives to maintain up-or-out promotion systems than large audit firms. Thus, it was expected that inter-organizational auditor mobility out of large audit firms is higher than inter-organizational auditor mobility out of small audit firms. Since the specific tests make a distinction between different types of transitions, this hypothesis can be tested by comparing the out of large firm mobility with the out of small firm mobility.

However, before this hypothesis can be tested some further elaborations need to be made. Up-or-out decisions are usually made within a seven to ten years apprenticeship period [see O'Flaherty and Siow (1995); and also the results on promotion velocity in chapter 2]. At the start of the apprenticeship period, mobility will be low. As the apprenticeship period evolves, auditors collect information on their probability of achieving partnership. Those who expect a negative partnership decision will start to leave the firm before the partnership decision will be made. Hence, large firm mobility will increase steadily until it reaches a maximum after seven to ten years of job tenure. After the period in which the partnership decision is made, there will be a steep decrease in auditor mobility. That is, auditors have either been promoted to partner and will remain with the firm until retirement, or have been dismissed after they were denied admission to the partnership. 
In contrast, auditors of small firms are expected to follow a regular mobility pattern as suggested by hypothesis 8 . Due to a so-called 'honeymoon period' of one or two years, the probability of inter-organizational auditor mobility initially increases and then gradually decreases with years of job tenure. Hence, comparing the probability of inter-organizational mobility of large and small firm auditors suggests the following pattern. In the first years of job tenure, auditors of audit firms using no up-or-out promotion systems (i.e. small firms) will have higher inter-organizational mobility. Thereafter, auditors of audit firms using up-or-out promotion systems (i.e. large firms) will have higher mobility. In the later years of job tenure, again auditors of audit firms using no up-or-out promotion systems (i.e. small firms) will have higher mobility. Accordingly, it can be predicted that:

$\mathrm{H}_{10}$ Comparing auditors of small and large firms per year of job tenure, inter-organizational mobility will initially be higher for auditors of small (non-Big Six) audit firms, thereafter inter-organizational mobility will be higher for auditors of large (Big Six) audit firms, and in the later years of job tenure inter-organizational mobility will again be higher for auditors of small (non-Big Six) audit firms.

\subsubsection{Audit quality and inter-organizational auditor mobility}

Like up-or-out promotion systems, audit quality differences between large and small audit firms predict a positive association between audit firm size and interorganizational mobility. Auditors from high quality audit firms generally possess better audit skills and abilities, as compared to auditors of low quality firms. According to human capital theory, these characteristics lead to better job opportunities and thus to a higher propensity to move.

To test for the separate effect of quality differences on inter-organizational mobility, the effect of the up-or-out system needs to be removed. Up-or-out rules usually create downward mobility to lower quality firms. If large and small audit firms would offer a similar level of audit quality, dismissed Big Six auditors would not easily move to non-Big Six audit firms and visa versa. This would create more mobility to business/government positions. Nevertheless, the assumption that large firms offer higher quality audit services than small firms can be expected to result in higher downward mobility from large firms to small firms, than upward mobility. Since the specific test of audit quality distinguishes different types of transitions between audit firms, it is hypothesized that:

$\mathrm{H}_{11}$ Inter-organizational auditor mobility from large (Big Six) audit firms to small (non-Big Six) audit firms is higher than inter- 
organizational auditor mobility from small (non-Big Six) audit firms to large (Big Six) audit firms.

\subsubsection{Client-specific investments and inter-organizational auditor mobility}

The existence of client-specific investments has not yet been investigated within the context of the accounting labour market. As argued in paragraph 3.3.2.1, large audit firms have a higher degree of specialization than small audit firms. This results in a higher degree of firm-specific capital of auditors of large firms, and consistent with human capital theory, firm-specific human capital is negatively associated with inter-organizational mobility.

However, to identify the effect of client-specific investments, the confounding effects of up-or-out promotion systems and audit quality differences need to be removed. These influences can be avoided by restricting the analysis to within Big Six and within non-Big Six moves. Since up-or-out systems and audit quality differences mainly apply to downward mobility to lower quality firms, observed differences between within Big Six and within non-Big Six moves can be attributed mainly to the effect of client-specific investments. Hence, the following hypothesis should hold:

$\mathrm{H}_{12}$ Inter-organizational auditor mobility between large (Big Six) audit firms is lower than inter-organizational auditor mobility between small (non-Big Six) audit firms.

\subsection{Methodology}

\subsubsection{Method}

This study examines the inter-organizational mobility of thirteen cohorts of newly qualified auditors. Event history analysis is used to identify the dynamic process of inter-organizational auditor mobility. Previous research used static research methods such as logistic analysis and regression analysis with dummy variables to address auditor mobility. However, event history analysis is more appropriate for such a dynamic process, where explanatory variables change over time and many subjects do not experience inter-organizational moves."

\footnotetext{
$"$ See paragraph 3.4.4 for a more elaborate overview of ewent history techniques.
} 
Following organizational studies on inter-organizational mobility, this study focuses on all subjects in a cohort and not only on those auditors who are employed in (large) audit firms. Consequently, a distinction can be made between the inter-organizational mobility of auditors at large and small audit firms and between auditors in- and outside public practice. Compared to previous research [see, e.g. Rhode, Sorensen and Lawler (1977); Arnold and Feldman (1982); Harrell (1990)] this study will examine a much longer career horizon to obtain data on the inter-organizational mobillity of auditors. This not only enables the examination of actual turnover instead of intent to turnover, but also the inclusion of complete career histories of subjects. Complete career histories give insight into successive career moves. Furthermore, since complete cohorts of auditors will be studied, for the first time actual probabilities of inter-organizational mobility in auditing can be identified. This study does not address the influence of personal attitudes on auditor mobility since they were extensively covered in previous studies [see, e.g. Gregson (1992)].

\subsubsection{Data collection}

To study the inter-organizational mobility of auditors, the same sample of auditors is used as for the study on career advancement in chapter $2 .{ }^{12}$ Hence, the data used in this study are thirteen cohorts of Dutch auditors, who received their license between January 1970 and December 1982. The inter-organizational mobility of these auditors is retrieved from the membership lists of the Dutch Institute of Registered Accountants. The membership lists provide information on the affiliation and position of auditors. Comparing successive lists gives information on changes of affiliation. Given the restrictions that career histories should be as time-complete as possible and that the data of January 1998 were the most recently available, the careers of the auditors were observed from January 1970 until January 1998. Since the membership lists were published bi-annually in some periods, it should be noted that not all changes might be included if more than one change of affiliation occurs within two years. However, in the years where annual membership lists are available, this rarely occurs. Furthermore, because the focus is on qualified auditors, it should be noted that only employer changes are included during their career as an auditor. Employer changes before individuals qualify as auditors are not included. However, since most individuals engage in education/apprenticeship agreements where the employer pays the cost of audit education, individuals have less incentives to change employers before

\footnotetext{
12 For a more elaborate description of the data collection, see paragraph 2.4 .2 .
} 
they qualify as auditors. Not only have individuals who have not finished their education fewer job-opportunities from a human capital perspective. Also, such agreements usually imply repayment of (a part) of the education costs, which reduces the propensity to move. Changes of affiliation as a result of a name change of audit firms or as a result of mergers or divestitures of audit firms were excluded.

In the period January 1970 - December 1982, 2623 individuals qualified as auditors. The majority of individuals in the sample $(59 \%)$ experienced interorganizational mobility. TABLE 1 gives descriptive information on the sample of auditors used in this study.

\section{TABLE 1}

Sample characteristics

Number of auditors per cohort

Cohort $1970 \quad 147$ auditors

Cohort $1971 \quad 166$ auditors

Cohort 1972203 auditors

Cohort 1973215 auditors

Cohort $1974 \quad 174$ auditors

Cohort 1975197 auditors

Cohort 1976204 auditors

Cohort 1977194 auditors

Cohort 1978220 auditors

Cohort 1979248 auditors

Cohort 1980204 auditors

Cohort 1981 231 auditors

Cohort 1982220 auditors
Education

1002 universitymeducated auditors (38\%)

1621 non-university educated auditors $(62 \%)$

Median age at qualification

31.6 years ( $\mathrm{min} .25 .2$ years, max. 62.3 years)

Employment at qualification

1434 auditors in public practice $(55 \%)$

1189 auditors outside public practice (45\%)

Auditor mobility

1544 auditors with mobility (59\%)

1079 auditors without mobility (41\%)

2623 auditors included in the study 


\subsubsection{Measurement of variables}

Hypotheses 1 , and 10 to 12 concern the organizational variable audit firm size (and in this context applied as the nature of an audit firm). Audit firms are classified into large (Big Six) and small (non-Big Six) firms. ${ }^{13}$ Since the reference category is business firms/government, audit firm size is addressed by two dummy variables: a Big Six variable, coded $\mathbb{1}$ if the auditor was with a Big Six firm and coded 0 if the auditor was with a non-Big Six firm or in business/government, and a non-Big Six variable, coded 1 if the auditor was with a non-Big Six firm and coded 0 if the auditor was with a Big Six firm or with business/government.

Personal variables used to explain auditor mobility are education (hypothesis 2), age at qualification (hypothesis 3), promotion to partnership (hypothesis 4), firm founder (hypothesis 5), date of qualification (hypothesis 6), and previous jobs (hypothesis 7). With respect to education, a distinction is made between university education, coded 1 , and non-university education, coded 0 . Age at qualification is measured in years, and controls for the study velocity of auditors. Further, since membership lists report the position of auditors, a distinction could be made between partners and non-partners. Promotion to partner is a time-varying covariate, which was coded 1 in the periods in which the auditor was a partner, and coded 0 otherwise. Firm founder is also a time-varying covariate, which was coded 1 in the periods in which the auditor was engaged with the firm he/she founded, and coded 0 otherwise. To measure firm founding by auditors, the auditors' names were compared with the names of the audit firms and when their names were part of the partnerships" names, the auditors were coded as firm founders. Note that this only occurs with small firms and sole practitioners and that sole practitioners are automatically coded as firm founders. Moreover, the date of qualification is interpreted as the starting point of the auditor's career. To measure the influence of the date of qualification on auditor mobility, distinction is made between two periods of qualification: a first period $\rrbracket 970$ to 1975 (coded 0) and a second period 1976 to 1982 (coded 1). Finally,

1.3 The Big six audit firms are: Arthur Andersen, Coopers \& Lybrand, Deloitte \& Touche, Errst \& Young, KPMG, and Price Waterhouse. During the period of study, four of these large international firms merged with large Dutch audit firms to obtain a dominant position in the Dutch audit market. The auditors who were with one of these large Dutch audit firms are also considered Big Six auditors. These Dutch audit firms are (current international name): Dijker en Doornbos (Coopers \& Lybrand), Klynveld Krayenhof \& Co (KPMG), Moret \& Limperg (Ernst \& Young), Nederlandse Accountants Maatschap (Deloitte \& Touche), and Van Dien \& Co (Coopers \& Lybrand). Arthur Andersen and Price Waterhouse did not seek cooperation with Dutch audit firms. 
previous jobs is a time-varying covariate and is included as a numerical variable. Its value changes with the number of previously held jobs.

Hypotheses 8 and 9 concern the timing of inter-organizational mobility. By comparing successive membership lists, changes of affiliation are observed and coded at the midpoint-date between the two membership lists. This enables the measurement of the timing of moves. Given the timing of moves, job tenure (hypothesis 8) is measured as the time from qualification to the first job move or as the time between two job moves. Work experience (hypothesis 9) is measured as the time since qualification as an auditor. Both job tenure and work experience are measured in months.

\subsubsection{Event history analysis}

Exent history models are used to examine the process of inter-organizational mobility of auditors. Event history analyses embody a family of statistical models used to analyse rates of change in discrete states, such as an auditor moving from a large audit firm to a small audit firm [see, e.g. Allison (1984); Petersen (1991)]. An event history is defined as a longitudinal account of the time of occurrence of one or more events for a sample of individuals [Allison (1984)]. Event history models contain the analysis of a risk set [Allison (1984)]. This is a set of individuals who have not experienced the event of interest (e.g. a transition or move from audit firm $x$ to audit firm $y$ ) and are therefore at risk for this event. In event history analysis, the dependent variable is the hazard rate (or transition rate), a function of the probability that the event will happen to an individual in the risk set at a particular time or during a particular time interval. In this way, hypotheses can be tested concerning the main effect of time on the probability that an event will occur. Therefore, event history models are preferable in longitudinal analyses of inter-organizational mobility. That is, it is important to know not only whether inter-organizational moves took place, but also exactly when they occurred. Another advantage of event history models is that they can be conducted even when many individuals do not experience the event under study. These cases are referred to as right censored. ${ }^{14}$ Event history models use all of the independent variables available for those cases up until the time of censoring. Traditional regression models treat auditors who did not experience inter-organizational mobility in the same way as those who did move. Including a dummy variable to differentiate between movers and non-movers ignores the timing of mobility and

14 There is no left censoring (individuals with missing starting times) since the moment of qualification, which is avalable for all auditors under study, is defined as a career"s starting time. 
restricting the analyses to movers might introduce a bias if there are differences between movers and non-movers [Petersen (1991)]. Furthermore, event history analysis enables the incorporation of time dependent co-variates. These variables take on different values over time and their effects on mobility are assumed to depend on time. As for dynamic processes like employee mobility, where variables change over time, it is important to account for time-changing variables [Morita, Lee and Mowday (1993)]. In the present study, it was possible to include time-varying measures for promotion to partner, number of previous moves and experience.

The specific form of event history analysis used in this study is the piecewise constant exponential model. This is a simple specification of the standard exponential model and assumes that the transition rate stays constant within a defined time period but varies between periods. The advantage of such a model is that it leaves optimal freedom with respect to the specific form of the time-dependence of the process [see Blossfeld and Rohwer (1995)]. When defining the time axis into time periods according to

$$
0=\tau_{1}<\tau_{2}<\tau_{3}<\ldots<\tau_{l} \text {, with } \tau_{L+\ell}=\infty,
$$

the $l$ th time period is defined as

$$
I_{l}=\left(\mathrm{t} \mid \tau_{l} \leq t \leq \tau_{l+1}\right) \quad l=1, \ldots, L .
$$

Given these time periods, the hazard rate can be formulated as:

where:

$$
\mathrm{r}_{\mathrm{jk}}(\mathrm{t})=\exp \left(\alpha_{l}^{(j k)}+A^{(j k)} \alpha^{(j k)}\right) \text { if } t \in I_{l},
$$

$r_{\mathrm{jk}}$ is the transition rate at $\mathrm{t}$, from origin state $\mathrm{j}$ to destination state $\mathrm{k}$;

$\hat{\alpha}_{J}^{(j k)}$ is a constant coefficient associated with the $l$ th time period;

$A^{(j k)}$ is a vector of covariates; and

$\alpha^{(j k)}$ is a vector of associated coefficients assumed not to vary with time periods. The hazard rate can be estimated using a method of partial likelihood.

Although the data are measured on a discrete-time basis, the model used here is a continuous-time model. Since inter-organizational mobility is a continuous process, where individuals can experience mobility at every point in time, the use of discrete-time models can lead to erroneous conclusions [see Carroll $\left(1983\right.$, p. 427)]. ${ }^{15}$

is But see also Petersen (1991) and Petersen and Koput (1992) for a discussion on the use of discrete and continuous-time models. 


\subsection{Results}

\subsubsection{Introduction}

This section will present the results for the hypotheses formulated in section 3.3 . First some descriptive statistics will be presented. After that, in paragraph 3.5.3 a model of total inter-organizational auditor mobility will be examined. Paragraph 3.5.4 presents the results on the influence of up-or-out promotion systems on inter-organizational auditor mobility. In paragraph 3.5 .5 the influence of quality differences between audit firms on inter-organizational auditor mobility will be presented, followed by an analysis on the influence of client-specific investments on inter-organizational auditor mobility in paragraph 3.5.6. The results in the figures and tables are presented on the basis of either number of years of work experience or number of years of job-tenure. Work experience starts when individuals qualify as an auditor and job-tenure starts when a new job is entered. Therefore, the "starting-point" of the analysis is either the date of qualification or the date entering a new job. Both allow comparisons between auditors from different annual cohorts.

\subsubsection{Descriptive statistics on inter-organizational auditor mobility}

In the period January 1970 - December 1982, 2623 individuals qualified as auditors. At the time of qualification, 1434 auditors $(=55 \%)$ were employed by audit firms, whereas 1189 auditors $(=45 \%)$ were employed outside public practice. This indicates that the auditors outside public practice form a rather large part of the auditor population and therefore the analysis of inter-organizational auditor mobility cannot be restricted to auditors in audit firms.

Moreover, a further division of the number of auditors in public practice indicates that 938 auditors $(=36 \%$ ) are employed with Big Six firms, while 496 auditors $(=19 \%)$ are with non-Big Six firms at the time of qualification. Furthermore, as indicated above, 1189 auditors $(=45 \%)$ are employed with business firms or are in a government position. FIGURE 1 shows the aggregate course of employments of the subjects under study. All auditors have an employment history of at least 15 years. That is, those individuals who became auditors at the end of the observation period (i.e. 1982) have an employment history of minimal 15 years. The maximum employment history is 28 years for those individuals who became auditors at the beginning of the observation period (i.e. 1970). FIGURE $I$ shows a decrease in the proportion of auditors engaged with Big Six firms, whereas the proportion of auditors in non-Big Six firms and 
business firms/government increases over the course of employments. Apparently, auditors leave Big Six firms to become employed with non-Big Six firms and business firms/government.

\section{FIGURE 1}

The course of employments of the auditors under study

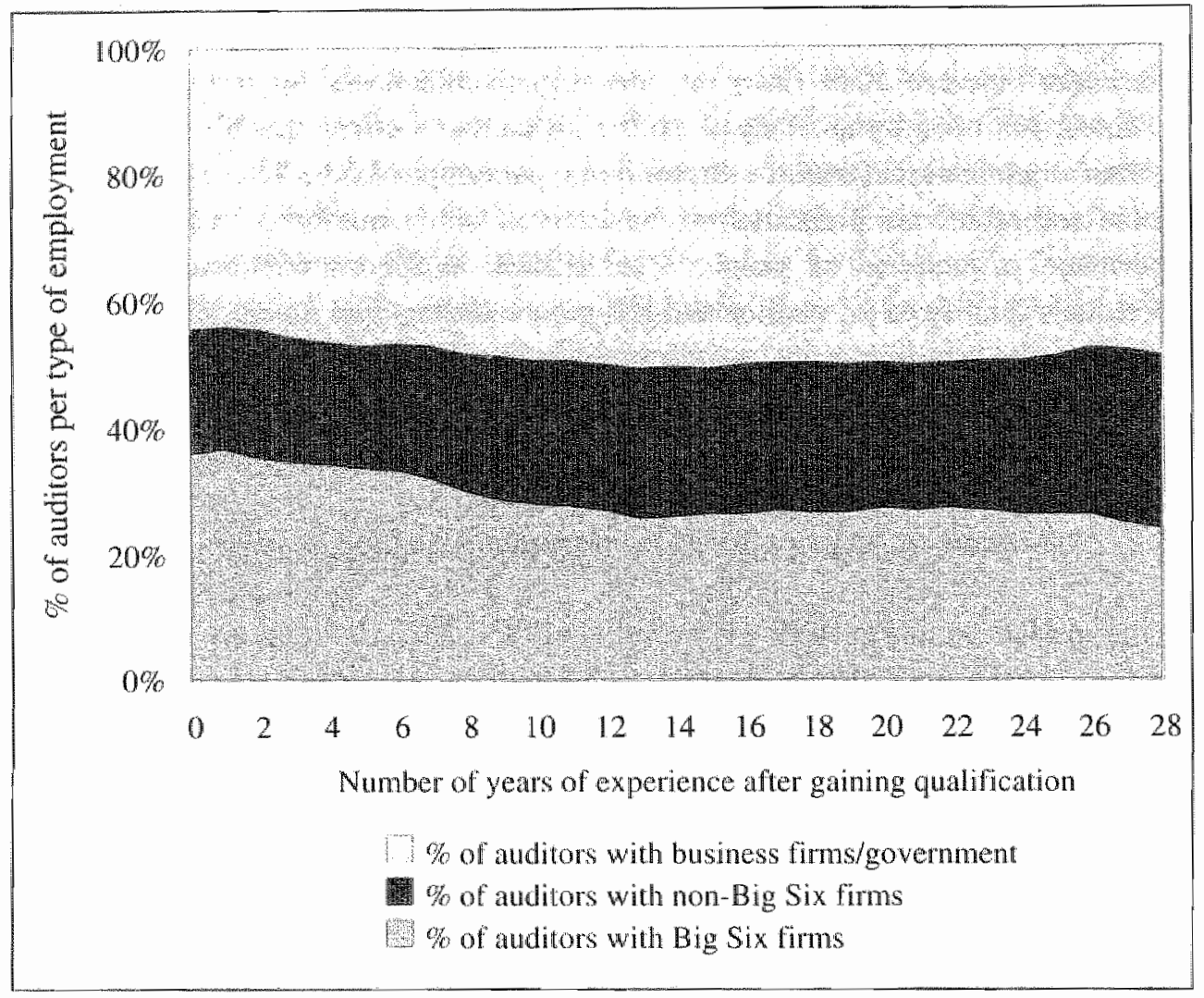

Panel A of TABLE 2 presents a profille of the number of moves per auditor. The majority of individuals in the sample experienced inter-organizational mobility (1544 auditors or 59\%). These auditors accounted for 2847 moves. This is on average 1.8 moves per auditor having inter-organizational mobility or 1.1 move per auditor overall. The maximum number of moves per auditor is seven. 


\section{TABLE 2}

A profile of inter-organizational moves

Panel A: Profile of the number of inter-organizational moves per auditor

Number of moves

Number of
auditors

1079

748

466

201

89

33

6

1
Percentage

of auditors
Total number of moves

Panel B: Profile of the nature of the inter-organizational moves

\begin{tabular}{c|cccc}
$\begin{array}{c}\text { Number of } \\
\text { inter-organizational } \\
\text { moves to: }\end{array}$ & $\begin{array}{c}\text { Number of inter-organizational moves from: } \\
\text { Big Six } \\
\text { audit firms }\end{array}$ & $\begin{array}{c}\text { Non-Big Six } \\
\text { audit firms }\end{array}$ & $\begin{array}{c}\text { Business firms/ } \\
\text { government }\end{array}$ & $\begin{array}{c}\text { number } \\
\text { of moves }\end{array}$ \\
\hline Big Six audit firms & 58 & 34 & 141 & 233 \\
Non-Big Six audit firms & 206 & 325 & 257 & 788 \\
Business firms/government & 417 & 193 & 1216 & 1826 \\
\hline
\end{tabular}


A profile of the nature of inter-organizational moves is given in Panel B of TABLE 2. It shows that, except for Big Six firms, inter-sector moves are the most common types of moves. Within Big Six moves are rare, whereas, for example, non-Big Six auditors move predominantly to other non-Big Six firms. Furthermore, as already shown in FIGURE 1, there is a net outflow of auditors from Big Six firms: 233 auditors move to Big Six firms while 681 auditors move out of Big Six firms. It appears that relatively many Big Six auditors experience mobility to non-Big Six firms and business firms/government. This is probably due to up-or-out systems maintained by Big Six firms. Moreover, a large part of the moves appears to be within the business firms/government segment (i.e. 1216 moves).

\subsubsection{A model of total inter-organizational auditor mobility}

Using event history analysis, this paragraph addresses the hypotheses on the general model of inter-organizational mobility (hypotheses 1 to 9). This general model only distinguishes one type of transition: inter-organizational moves, irrespective of the nature of the move (i.e. transitions from one employer to another). This will provide insight in the total inter-organizational mobility of auditors. In paragraphs 3.5 .4 to 3.5 .6 , analyses of the nature of interorganizational moves are presented (i.e. multiple transitions). Following previous studies on employee mobility [see, e.g. Carroll and Mayer (1986); Greve (1994)], job-tenure is taken as the unit of analysis. This enables the inclusion of the whole sample of moves in a single estimation [see Blossfeld and Rohwer (1995, p.104109)].

TABLE 3 presents correlations for the variables used in the event history analysis. Although most correlations between the variables are statistically significant at the 0.01 or 0.05 levels, they are all moderately low. The highest correlation was found between promotion to partnership and firm founder (0.273). This could be expected because only owners (i.e. partners / sole practitioners) can be classified as firm founders. Furthermore, the highest correlation of audit firmsize with other variables is the positive correlation of Big Six Firm size with promotion to partner $(0.240)$ and with firm founder $(0.234)$. Because of these relatively low correlations all explanatory variables are included in the analyses.

To provide a graphical representation of the timing of the total number of inter-organizational moves, the survival rate as well as the transition rate are estimated. Given single transitions, FIGURE 2 presents the survival rate function for the inter-organizational mobility of the entire sample of auditors. The survival rate function describes the probability of experiencing no mobility as a function of 


\section{TABLE 3}

Correlations of the explanatory variables

Correlation coefficients ${ }^{\mathrm{a}}$

Firm size Big Six $\quad 1.000$

Firm size non-Big Six $-0.216^{c} \quad 1.000$

$\begin{array}{llll}\text { Education } & 0.001 & -0.022 & 1.000\end{array}$

$\begin{array}{lllll}\text { Age at qualification } & -0.135^{\mathrm{c}} & 0.033^{\mathrm{b}} & -0.208^{\mathrm{c}} & 1.000\end{array}$

Promotion to partner $0.056^{\circ}$

Firm founder $\quad-0.084^{\circ}$

$\begin{array}{lll}0.240^{c} & -0.037^{\mathrm{b}} & -0.048^{\mathrm{b}}\end{array}$

1.000

Date of qualification

$0.234^{\circ}$

$-0.032$

$0.046^{\mathrm{b}}$

$0.273^{\circ}$

1.000

Previous jobs

$-0.065^{\circ}$

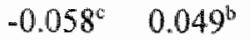

$-0.038^{\mathrm{b}}-0.019$

0.030

1.000

Firm Firm Education

$\begin{array}{lll}0.121^{\circ} & 0.049^{\mathrm{b}}\end{array}$

$0.169^{\circ} \quad 0.021$

1.000

size

size

Age Promotion firm

Date Previous

Big Six non-Big Six qualification

qualification

"For the variables measured on a dichotomous scale, the Cramer coefficient $C$ of association is presented.

b Correlation is significant at the 0.05 level (2-tailed)

c Correlation is significant at the 0.01 level (2-tailed)

time [see Blossfeld and Rohwer (1995, pp. 59-60)]. The median survival time, or the time at which $50 \%$ of the auditors experienced job mobility, is about eleven years.

Furthermore, FIGURE 3 depicts the transition rate or hazard rate function for the whole sample. As mentioned before, the transition rate function describes the probability of leaving a particular job per unit of time. The transition rate is computed as the number of job moves per unit time in the interval (in this case months), divided by the average number of auditors who have not yet moved at the mid-point of the interval [see Blossfeld and Rohwer (1995, pp. 59-60)]. The transition rate in FIGURE 3 is non-linear and non-monotonic. The probability of inter-organizational mobility increases until approximately three years, and then decreases gradually. This shape suggests that standard estimation models, which are very restrictive in the form of the transition or hazard rate as a function of time, will lead to mis-specification of the coefficient estimates. Therefore, a piecewise constant exponential model, which puts no restrictions on the time pattern of mobility, will be used. 


\section{FIGURE 2}

Life table survival rate function for the job-transition of auditors

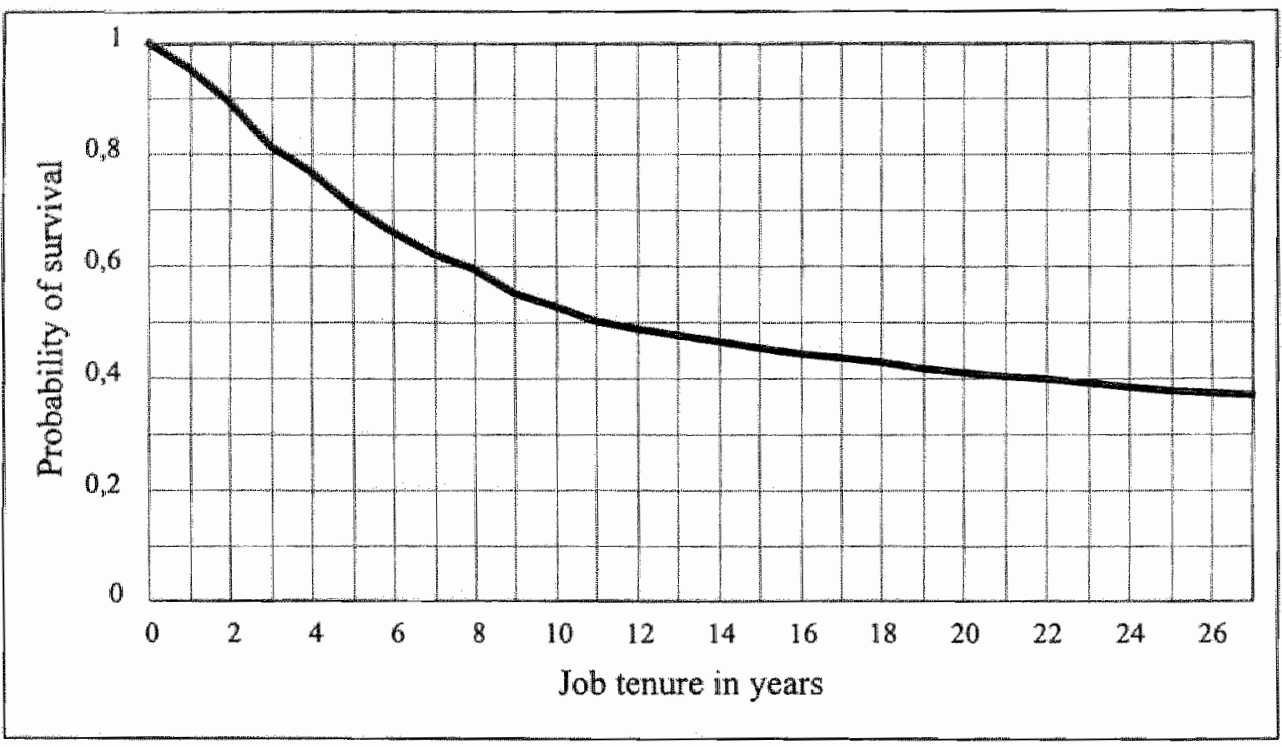

FIGURE 3

Life table transition rate function for job-durations of auditors

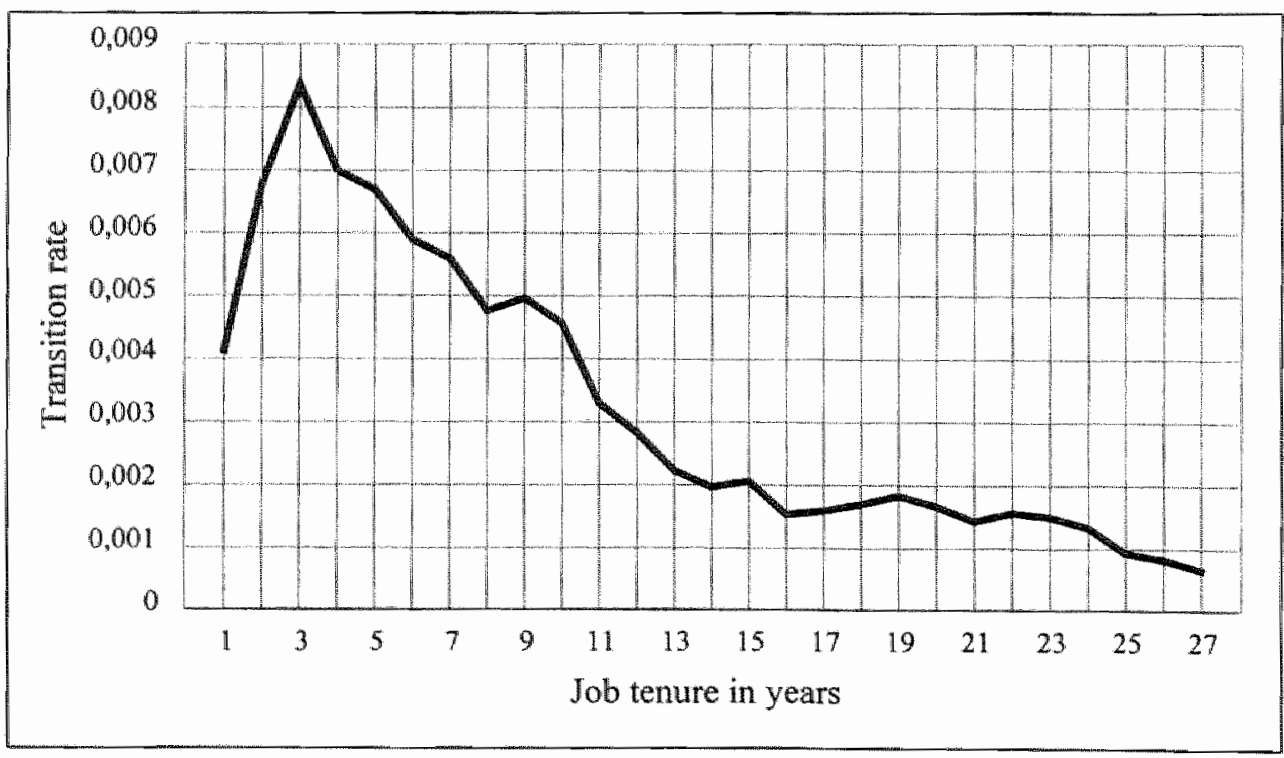


TABLE 4 shows the regression results estimating the piecewise constant exponential model for the total hazard function. That is, for all inter-organizational moves in the sample. Panel A presents the coefficient estimates while panel B gives the model estimates. Examining the coefficient estimates of the independent variables of the total hazard function in Panel $A$, reveals that hypothesis 1 is not supported. Four variables were included in the model to test for the effect of audit firm size on total inter-organizational auditor mobility, but only the coefficient estimates of 'Employer at job-start' are statistically significant (at the 0.01 level). A t-test for the difference of two regression coefficients [see Arnold (1982, p.156)] indicates that the difference between the coefficient estimates of Big Six employer at job-start and non-Big Six employer at job-start is not statistically significant ( $\mathrm{t}$-value $=0.310$ at $12960 \mathrm{df}, p=0.243$ ), lending no support to hypothesis $1 .{ }^{16}$ Note however, that the three factors influencing the relationship between audit firm size and inter-organizational mobility will be examined separately by specific tests in the paragraphs 3.5.4 to 3.5.6.

With respect to the other variables, the coefficient estimates for education, age at qualification, promotion to partner, firm founder and date of qualification are statistically significant (at the 0.05 level). Moreover, all signs are in the predicted direction, supporting hypotheses 2 to 6 . Only the coefficient estimate for number of previously held jobs is not significant at conventional levels (hypothesis 7).

The coefficient estimates per period in panel $\mathrm{A}$ indicate that the average rate of job change is non-monotonic. The estimated coefficients for the transition rate initially increase from -4.409 in period 1 ( 0 to 1.5 years) to -3.788 in period 2 (1.5 to 3 years), and then decrease. ${ }^{17}$ This pattern was also shown in FIGURE 3 were the transition rate function was plotted. Hence, hypothesis 8 on the timing of inter-organizational moves is supported.

16. The negative coefficient estimates for the two covariates employer at job start Big Six and employer at job start non-Big Six indicate that auditors in audit firms have a lower propensity to move than auditors in business/government, the reference category.

17 Given the influence of the covariates, the coefficient for the transition rate in period 2 is 3.788. This implies a transition rate of $e^{(-3.788)}=0.023$, which is an annual average number of moves of $0.023 * 12$ months $=0.28$, or an average job-duration of $1 / 0.023=43$ months. 
Furthermore, an analysis on inter-organizational mobility is undertaken where the timing of mobility is measured by workforce experience (instead of using jobutenure as time scale). A transition rate function scaled by workforce experience shows a similar pattern of mobility as that of job tenure in FIGURE 3. Also, a piecewise constant exponential model was estimated using workforce experience as time scale. The estimated coefficients follow a similar pattern as shown in TABLE 4. ${ }^{18}$ Therefore, hypothesis 9 is supported.

When comparing the model with only a constant term and the model with covariates, a likelihood ratio test is performed. This test shows that including explanatory variables in the model significantly improves the model specification (chi square $=1271.888, p=0.000$ ).

\subsubsection{Up-or-out promotion systems and inter-organizational auditor mobility}

In this paragraph, a specific test is performed on the effect of up-or-out promotion systems on inter-organizational mobility. Hypothesis 10 states that interorganizational mobility will initially be higher for auditors of non-Big Six firms, then it will be higher for auditors of Big Six audit firms, and in the later years of job tenure mobility will again be higher for auditors of non-Big Six audit firms. To test for the mobility pattern specified above, piecewise constant exponential models were specified for the transitions of Big Six auditors and non-Big Six auditors.

First, FIGURE 4 graphically illustrates the transition rates of Big Six and non-Big Six auditors. Both rates are non-monotonic, and reflect what was suggested in hypothesis 10. The transition rate for Big Six auditors increased steadily to reach a peak at nine years and then declined steeply and remained low in the later years of job tenure, whereas the transition rate for non-Big Six auditors reached a peak at three years and declined gradually to remain at a rather substantial level in the later years of job tenure. Hence, large audit firms appear to use up-or-out rules with an apprenticeship period of about seven to ten years.

18 The coefficient estimates per period are: Period-1 -4.172 , Period-2 4.023 , Period-3 -4.113 , Period-4 -4.057, Period-5 -4.121, Period-6 -4.271, Period-7 -4.351, Period-8 -4.520, Period-9 -4.616 , Period $-10-4.709$, and Period 11 - 4.849 . 


\section{TABLE 4}

Coefficient estimates predicting the probability of total inter-organizational mobility

\section{Panel A: Coefficient estimates ${ }^{\mathrm{a}}$}

Variable

Period-1
Period-2
Period-3
Period-4
Period-5
Period-6
Period-7
Period-8
Period-9
Period-10
Period-11
Employer at qualification Big Six

Employer at qualification non-Big Six -0.083

Employer at job-start Big Six

Employer at job-start non-Big Six

Education

Age at qualification

Promotion to partner

Firm founder

Date of qualification

Previous jobs
Coefficient Error T-statistic Probability ${ }^{b}$

$\begin{array}{rrrr}-4.409 & 0.163 & -26.988 & 0.000 \\ -3.788 & 0.160 & -23.534 & 0.000 \\ -3.933 & 0.163 & -24.154 & 0.000 \\ -4.062 & 0.166 & -24.542 & 0.000 \\ -4.129 & 0.169 & -24.426 & 0.000 \\ -4.130 & 0.172 & -24.062 & 0.000 \\ -4.237 & 0.177 & -24.003 & 0.000 \\ -4.554 & 0.188 & -24.233 & 0.000 \\ -4.810 & 0.202 & -23.800 & 0.000 \\ -4.988 & 0.217 & -23.020 & 0.000 \\ -5.282 & 0.188 & -28.061 & 0.000 \\ -0.062 & 0.050 & -1.249 & 0.212 \\ -0.083 & 0.055 & -1.517 & 0.129 \\ -0.254 & 0.058 & -4.387 & 0.000 \\ -0.229 & 0.056 & -4.109 & 0.000 \\ 0.310 & 0.039 & 7.957 & 0.000 \\ -0.031 & 0.004 & -7.097 & 0.000 \\ -1.070 & 0.072 & -14.830 & 0.000 \\ -0.268 & 0.109 & -2.466 & 0.014 \\ 0.188 & 0.039 & 4.867 & 0.000 \\ -0.028 & 0.019 & -1.448 & 0.148\end{array}$

\section{Panel B: Model estimates}

Log likelihood model without covariates: -18136.570

Log likelihood model with covariates: $\quad-17500.626$

Log likelihood ratio test statistic:

$1271.888^{\mathrm{c}}$

a For this model, eleven time periods were defined. The first ten periods have a length of 18 months each, and the eleventh period is an open-ended intervall untill the end the observation period.

- Coefficient significance tests are two-tailed.

- The log likelihood ratio test statistic follows approximately a chi-square distribution and is statistically significant at the 0.01 level $(\mathrm{df}=10, p=0.000)$. 
Furthermore, TABLE 5 presents the coefficient estimates and the corresponding annual transition rates of the estimated piecewise constant exponential models for Big Six and non-Big Six auditors. The coefficients per period were estimated without covariates to obtain the parameters for the baseline transition rates [see Blossfeld and Rohwer $\left(1995\right.$, p. 112)] ${ }^{19}$ To test for differences between Big Six firm and non-Big Six firm mobility, a series of three permutation tests was conducted with respect to the three career stages, mentioned in hypothesis 10 . The length of these periods depends on the timing of the up-or-out decisions which take place in the second period. Because apprenticeship periods extend over seven to ten years, with an outflow period of about two years before and after this period, inter-organizational mobility as a result of up-or-out rules will take place between the fifth and twelfth year of job tenure. This implies that first period comprises the first four years of job tenure and that the third period comprises years the 13 to 26 . In the first and third period, non-Big Six firm mobility is significantly larger (at the 0.10 level) than Big Six firm mobility ( $p=$ 0.063 respectively $p=0.000$ ). In period two, Big Six firm mobility is significantly larger (at the 0.05 level) than non-Big Six firm mobility $(p=0.008)$. Hence, upor-out promotion systems, which affect the inter-organizational mobility of auditors, are mainly used by large audit firms and cause a large outflow of Big Six auditors between their fifth and twelfth year of job tenure. This provides support for hypothesis 10 .

Moreover, TABLE 5 shows that the coefficient estimates for the covariates education, promotion to partner and date of qualification are statistically significant (at the 0.01 level) and act in the expected direction in both models. The coefficient estimate for firm founder is only significant (at the 0.01 level) for nonBig Six firm mobility. This was to be expected since only non-Big Six auditors qualify as firm founders. The number of previously held jobs was not significant in both models, confirming the results of the general model of inter-organizational mobility.

19 However, an analysis including the covariates revealed similar non-monotonic rate patterns. The covariates were not included to obtain the net effect over time (i.e. the baseline transition rate). If covariates are included, they will explain at least a part of the transition rate pattern and thus affect the parameters for the time periods, which makes them lless usable in a comparative analysis. 


\section{FIGURE 4}

Transition rate functions for auditors of Big Six and non-Big Six audit firms

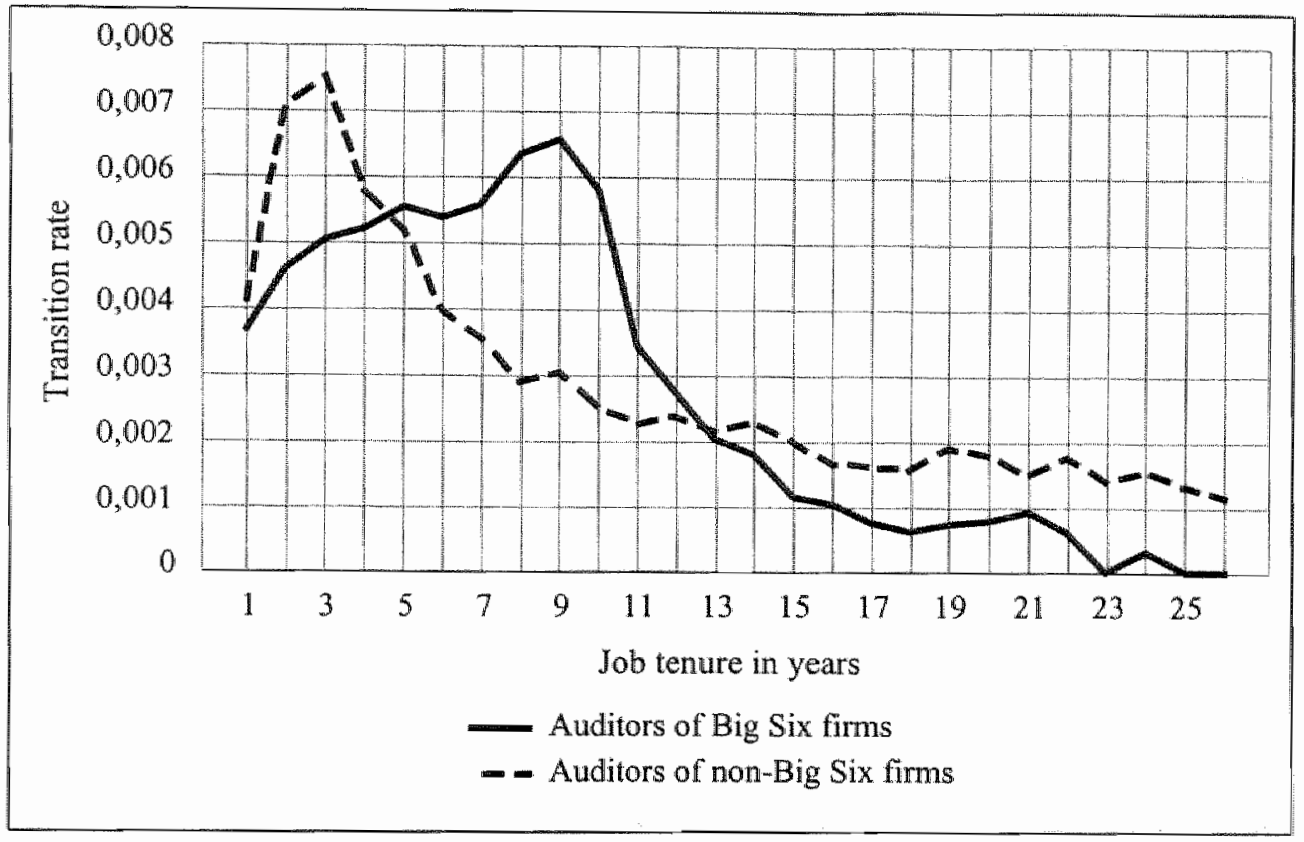

\subsubsection{Audit quality and inter-organizational auditor mobility}

Hypothesis 11 posits that audit quality differences between large and small audit firms provides auditors of high quality audit firms with better opportunities to change employer. Yet, to test for the separate effect of audit quality on interorganizational mobility, the effect of up-or-out systems needs to be controlled for. Therefore, the quality difference between Big Six and non-Big Six audit firms is examined by restricting the analysis to the mobility rates between these two types of firms. Piecewise constant exponential models were estimated for the transitions of Big Six auditors to non-Big Six firms and of non-Big Six auditors to Big Six firms.

FIGURE 5 depicts the transition rate functions for auditors moving from Big Six to non-Big Six audit firms and for auditors moving from non-Big Six to Big Six audit firms. These functions indicate that Big Six auditors more easily move to non-Big Six firms than visa versa. The fact that so few non-Big Six auditors enter Big Six firms probably reflects a quality difference between large and small audit firms. However, if large firms have firm internal labour markets (i.e. staffing senior positions 


\section{TABLE 5}

The effect of up-or-out promotion systems on inter-organizational mobility: Coefficient estimates and transition rates of Big Six firm and non-Big Six firm mobility.

\begin{tabular}{|c|c|c|c|c|c|c|}
\hline Variables & $\begin{array}{l}\text { Big Six } \\
\text { Coefficient }\end{array}$ & $\begin{array}{l}\text { frm mo } \\
\text { Prob. }\end{array}$ & $\begin{array}{l}\text { bility } \\
\text { Transition } \\
\text { rate }^{b_{n} x}\end{array}$ & Coefficient & $\begin{array}{l}\text { ix firm } \\
\text { Prob. }\end{array}$ & $\begin{array}{c}\text { mobility } \\
\text { Transition } \\
\text { rate }^{\mathrm{b} c}\end{array}$ \\
\hline Period-1 & -5.607 & 0.000 & $4.4 \%$ & -5.495 & 0.000 & $4.9 \%$ \\
\hline Period-2 & -5.371 & 0.000 & $5.6 \%$ & -4.941 & 0.000 & $8.6 \%$ \\
\hline Period-3 & -5.267 & 0.000 & $6.2 \%$ & -4.849 & 0.000 & $9.4 \%$ \\
\hline Period-4 & -5.216 & 0.000 & $6.5 \%$ & -5.150 & 0.000 & $7.0 \%$ \\
\hline Period 5 & -5.179 & 0.000 & $6.8 \%$ & -5.244 & 0.000 & $6.3 \%$ \\
\hline Period -6 & -5.206 & 0.000 & $6.6 \%$ & -5.523 & 0.000 & $4.8 \%$ \\
\hline Period-7 & -5.164 & 0.000 & $6.9 \%$ & -5.632 & 0.000 & $4.3 \%$ \\
\hline Period-8 & -5.043 & 0.000 & $7.7 \%$ & -5.870 & 0.000 & $3.4 \%$ \\
\hline Period-9 & -5.024 & 0.000 & $7.9 \%$ & -5.806 & 0.000 & $3.6 \%$ \\
\hline Period-10 & -5.121 & 0.000 & $7.2 \%$ & -6.050 & 0.000 & $2.8 \%$ \\
\hline Period-11 & -5.696 & 0.000 & $4.0 \%$ & -6.230 & 0.000 & $2.4 \%$ \\
\hline Period-12 & -5.882 & 0.000 & $3.3 \%$ & -6.104 & 0.000 & $2.7 \%$ \\
\hline Period-13 & -6.250 & 0.000 & $2.3 \%$ & -6.221 & 0.000 & $2.4 \%$ \\
\hline Period-14 & -6.351 & 0.000 & $2.1 \%$ & -6.118 & 0.000 & $2.6 \%$ \\
\hline Period-15 & -6.761 & 0.000 & $1.4 \%$ & -6.298 & 0.000 & $2.2 \%$ \\
\hline Period-16 & -6.894 & 0.000 & $1.2 \%$ & -6.425 & 0.000 & $1.9 \%$ \\
\hline Period-17 & -7.179 & 0.000 & $0.9 \%$ & -6.500 & 0.000 & $1.8 \%$ \\
\hline Period-18 & -7.351 & 0.000 & $0.8 \%$ & -6.483 & 0.000 & $1.8 \%$ \\
\hline Period-19 & -7.206 & 0.000 & $0.9 \%$ & -6.330 & 0.000 & $2.1 \%$ \\
\hline Period-20 & -7.015 & 0.000 & $1.1 \%$ & -6.391 & 0.000 & $2.0 \%$ \\
\hline Period-21 & -6.831 & 0.000 & $1.3 \%$ & -6.602 & 0.000 & $1.6 \%$ \\
\hline Period-22 & -6.993 & 0.000 & $1.1 \%$ & -6.310 & 0.000 & $2.2 \%$ \\
\hline Period-23 & -13.795 & 0.573 & $0.0 \%$ & -6.714 & 0.000 & $1.5 \%$ \\
\hline Period-24 & -7.082 & 0.000 & $1.0 \%$ & -6.557 & 0.000 & $1.7 \%$ \\
\hline Period-25 & -13.795 & 0.699 & $0.0 \%$ & -6.789 & 0.000 & $1.4 \%$ \\
\hline Period-26 & -13.795 & 0.743 & $0.0 \%$ & -6.913 & 0.759 & $1.2 \%$ \\
\hline Education & 0.534 & 0.000 & & 0.380 & 0.000 & \\
\hline Age at qualification & -0.041 & 0.000 & & 0.008 & 0.401 & \\
\hline Promotion to partner & $r-1.591$ & 0.000 & & -1.450 & 0.000 & \\
\hline Firm founder & 0.213 & 0.532 & & -0.553 & 0.014 & \\
\hline Date of qualification & 0.230 & 0.004 & & 0.231 & 0.008 & \\
\hline Previous jobs & 0.087 & 0.267 & & 0.065 & 0.182 & \\
\hline
\end{tabular}

"For this estimation, 26 time periods were defined of one year each. The time periods are based on job tenure, which is defined as the time in a job.

b The transition rate is presented percentages per year.

- One-tailed $p$ for a permutation test (paired replicates) for the difference between Big Six firm mobility and non-Big Six mobility is 0.063 for the first career stage (period-1 to period-4), 0.008 for the second career stage (period -5 to period-12), and 0.000 for the third career stage (period-13 to period-26). 
by recruiting internally) [see Wholey (1985)], lateral entry by non-Big Six auditors would be scarce due to staffing policies instead of quality differences. Therefore, the entry from business/government positions Big Six firms was also examined. If these auditors more frequently acquire positions in Big Six firms, the influence of internal staffing policies is less likely. FIGURE 5 also contains the transition rate function for auditors moving from business/government to Big Six firms and shows that auditors in business/government more frequently acquire positions in Big Six firms than non-Big six auditors do. A further observation is that up-or-out promotion systems have a prominent effect on the mobility from. large to small firms, as can be seen by the peak at year nine. Therefore, an additional analysis needs to be conducted controlling for the effect of up-or-out decisions between the fifth and twelfth year of job tenure. ${ }^{20}$

TABLE 6 presents the coefficient estimates and the annual transition rates of the estimated piecewise constant exponential models for Big Six and non-Big Six firm mobility, for auditors. The coefficients per period were estimated without covariates to obtain the parameters for the baseline transition rates. A t-test indicates that the mobility rates from Big Six to non-Big Six audit firms are significantly higher (at the 0.01 level) than the mobility rates from non-Big Six to Big Six firms $(t-v a l u e=6.561, p=0.000)$. Furthermore, at the 0.01 level, significantly more auditors from business'government acquire positions with Big Six firms than non-Big Six firm auditors do (t-value $=-3.723, p=0.001$ ). This indicates that Big Six audit firms quite frequently staff (senior) positions by lateral entry, and that internal staffing policies are not a barrier for non-Big Six auditors to enter Big Six firms.

A further test was conducted to exclude any possible effects of up-or-out promotion systems on the downward mobility of Big Six auditors. As indicated in the paragraph 3.5.4, up-or-out rules are only thought to create mobility between the fifth and twelfth year of job tenure. Accordingly, an analysis was conducted with respect to the early career stages (i.e. the first four years of job tenure) and in the later career stages (i.e. the thirteenth to twenty-sixth year of job tenure). A permutation test indicates that with respect to these career stages mobility rates from Big Six to non-Big Six audit firms are still significantly higher (at the 0.01 level) than the mobility rates from non-Big Six to Big Six firms $(p=0.001)$. Hence, hypothesis 11 is supported. From an auditor mobility perspective, evidence is provided on the quality difference between large and small audit firms.

20 See the previous paragraph, where it was suggested that up-or-out rules will only affect interorganizational mobility between the fifth and twelfth year of job tenure. 
TABLE 6 also indicates that the coefficient estimates for the covariates age at qualification, promotion to partner and firm founder are statistically significant (at the 0.05 level) and act in the expected direction for moves between large and small audit firms. The coefficient estimate for education is only significant (at the 0.05 level) for mobility from non-Big Six to Big Six firms. Furthermore, most coefficient estimates for mobility from business/government to large audit firms are not statistically significant (at the 0.05 level). For the variables promotion to partner and firm founder this can be explained by the fact that they do not apply to this type of mobility. That is, auditors in a business/government position cannot qualify as partners or firm founder of an audit firm at that time. All in all, however, most coefficient estimates confirm the results of the general model of inter-organizational mobility.

\section{FIGURE 5}

Transition rate functions for auditors moving from Big Six to non-Big Six audit firms, from non-Big Six to Big Six audit firms, and from business/government to Big Six audit firms

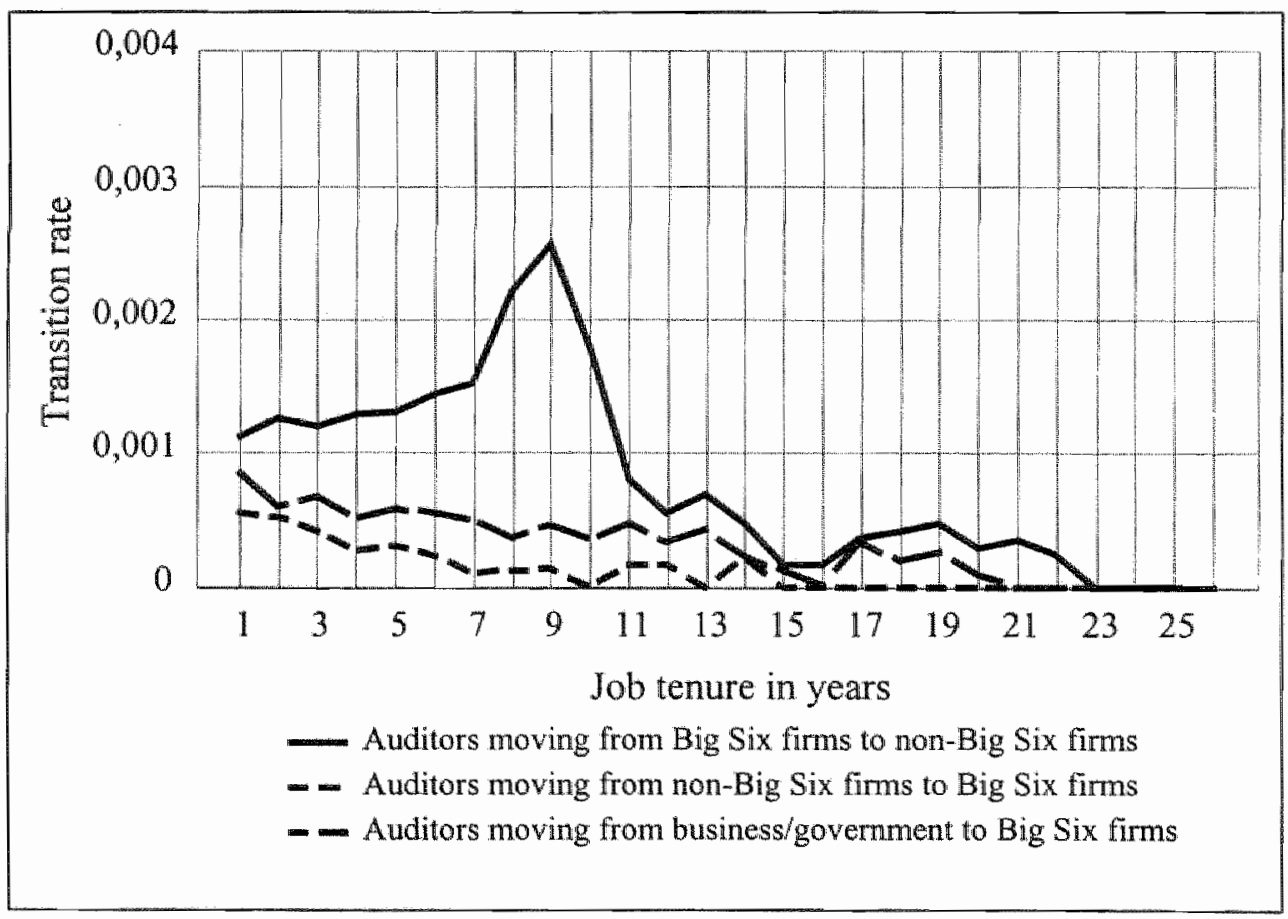




\section{TABLE 6}

The effect of audit quality on inter-organizational mobility:

Coefficient estimates and transition rates of mobility from Big Six to non-Big Six firms, from non-Big Six to Big Six firms, and from business/government to Big Six firms.

\begin{tabular}{|c|c|c|c|c|c|c|c|c|c|}
\hline \multirow[b]{2}{*}{ Variables } & \multicolumn{3}{|c|}{$\begin{array}{c}\text { Mobility from } \\
\text { Big Six to non-Big Six }\end{array}$} & \multicolumn{3}{|c|}{$\begin{array}{c}\text { Mobility from } \\
\text { non-Big Six to Big Six }\end{array}$} & \multicolumn{3}{|c|}{$\begin{array}{l}\text { Mobility from businesi/ } \\
\text { government to Big Six }\end{array}$} \\
\hline & & & & Coeff. & & & Coeff. & & \\
\hline Period-1 & -6.705 & 0.000 & $1.5 \%$ & -7.493 & 0.000 & $0.7 \%$ & -7.133 & 0.000 & $1.0 \%$ \\
\hline Period-2 & -6.586 & 0.000 & $1.7 \%$ & -7.538 & 0.000 & $0.6 \%$ & -7.430 & 0.000 & $0.7 \%$ \\
\hline Period-3 & -6.623 & 0.000 & $1.6 \%$ & -7.728 & 0.000 & $0.5 \%$ & -7.327 & 0.000 & $0.8 \%$ \\
\hline Period-4 & -6.557 & 0.000 & $1.7 \%$ & -8.162 & 0.000 & $0.3 \%$ & -7.646 & 0.000 & $0.6 \%$ \\
\hline Period-5 & -6.550 & 0.000 & $1.7 \%$ & -8.057 & 0.000 & $0.4 \%$ & -7.489 & 0.000 & $0.7 \%$ \\
\hline Period-6 & -6.477 & 0.000 & $1.8 \%$ & -8.385 & 0.000 & $0.3 \%$ & -7.581 & 0.000 & $0.6 \%$ \\
\hline Period-7 & -6.399 & 0.000 & $2.0 \%$ & -8.999 & 0.000 & $0.1 \%$ & -7.679 & 0.000 & $0.6 \%$ \\
\hline Period-8 & -6.059 & 0.000 & $2.8 \%$ & -8.915 & 0.000 & $0.2 \%$ & -8.038 & 0.000 & $0.4 \%$ \\
\hline Period-9 & -5.896 & 0.000 & $3.3 \%$ & -8.862 & 0.000 & $0.2 \%$ & -7.765 & 0.000 & $0.5 \%$ \\
\hline Period-10 & -6.304 & 0.000 & $2.2 \%$ & -14.579 & 0.427 & $0.0 \%$ & -8.049 & 0.000 & $0.4 \%$ \\
\hline Period-11 & -7.083 & 0.000 & $1.0 \%$ & -8.715 & 0.000 & $0.2 \%$ & -7.747 & 0.000 & $0.5 \%$ \\
\hline Period-12 & -7.441 & 0.000 & $0.7 \%$ & -8.588 & 0.000 & $0.2 \%$ & -8.112 & 0.000 & $0.4 \%$ \\
\hline Period-13 & -7.179 & 0.000 & $0.9 \%$ & -14.579 & 0.477 & $0.0 \%$ & -7.757 & 0.000 & $0.5 \%$ \\
\hline Period-14 & -7.637 & 0.000 & $0.6 \%$ & -8.421 & 0.000 & $0.3 \%$ & -8.319 & 0.000 & $0.3 \%$ \\
\hline Period 15 & -8.707 & 0.000 & $0.2 \%$ & -14.579 & 0.511 & $0.0 \%$ & -8.952 & 0.000 & $0.2 \%$ \\
\hline Period-16 & -8.636 & 0.000 & $0.2 \%$ & -14.579 & 0.545 & $0.0 \%$ & -13.902 & 0.279 & $0.0 \%$ \\
\hline Period-17 & -7.872 & 0.000 & $0.5 \%$ & -14.579 & 0.566 & $0.0 \%$ & -7.977 & 0.000 & $0.4 \%$ \\
\hline Period-18 & -7.756 & 0.000 & $0.5 \%$ & -14.579 & 0.611 & $0.0 \%$ & -8.403 & 0.000 & $0.3 \%$ \\
\hline Period-19 & -7.612 & 0.000 & $0.6 \%$ & -14.579 & 0.637 & $0.0 \%$ & -8.205 & 0.000 & $0.3 \%$ \\
\hline Period-20 & -8.113 & 0.000 & $0.4 \%$ & -14.579 & 0.674 & $0.0 \%$ & -13.902 & 0.480 & $0.0 \%$ \\
\hline Period-21 & -7.930 & 0.000 & $0.4 \%$ & -14.579 & 0.702 & $0.0 \%$ & -13.902 & 0.536 & $0.0 \%$ \\
\hline Period-22 & -7.686 & 0.000 & $0.6 \%$ & -14.579 & 0.741 & $0.0 \%$ & -13.902 & 0.606 & $0.0 \%$ \\
\hline Period-23 & -12.990 & 0.428 & $0.0 \%$ & -14.579 & 0.763 & $0.0 \%$ & -13.902 & 0.644 & $0.0 \%$ \\
\hline Period-24 & -12.990 & 0.498 & $0.0 \%$ & -14.579 & 0.791 & $0.0 \%$ & -13.902 & 0.704 & $0.0 \%$ \\
\hline Period-25 & -12.990 & 0.587 & $0.0 \%$ & -14.579 & 0.832 & $0.0 \%$ & $-13,902$ & 0.777 & $0.0 \%$ \\
\hline Period-26 & -12.990 & 0.644 & $0.0 \%$ & -14.579 & 0.836 & $0.0 \%$ & -13.902 & 0.796 & $0.0 \%$ \\
\hline Education & 0.134 & 0.377 & & 0.744 & 0.037 & & -0.071 & 0.684 & \\
\hline Age at qualification & -0.066 & 0.000 & & -0.157 & 0.0110 & & -0.061 & 0.001 & \\
\hline Promotion to partner & $r-1.639$ & 0.000 & & -1.324 & 0.002 & & -0.906 & 0.368 & \\
\hline Firm founder & -1.601 & 0.000 & & -1.738 & 0.024 & & -7.996 & 0.878 & \\
\hline Date of qualification & n 0.336 & 0.021 & & 0.297 & 0.406 & & 0.210 & 0.234 & \\
\hline Previous jobs & 0.177 & 0.174 & & -0.535 & 0.061 & & -0.619 & 0.000 & \\
\hline
\end{tabular}

a For this estimation, 26 time periods were defined of one year each. The time periods are based on job tenure, which is defined as the time in a job.

b. The transition rate is presented percentages per year.

- The $t$-value for paired samples for the difference between the mobility rates from Big Six to non-Big Six and non-Big Six to Big Six firms is $6.561(26 \mathrm{df}, p=0.000)$. One-tailed $p$ for a permutation test (paired replicates) for the difference between the mobility rates from Big Six to non-Big Six and non-Big Six to Big Six firms in the first four years of job tenure and after twelve years of job tenure is 0.001 . The $t$-value for paired samples for the difference between the mobility rates from non-Big Six to Big Six and business/government to Big Six firms is $-3.723(26 \mathrm{df}, p=0.001)$. 


\subsubsection{Client-specific investments and inter-organizational auditor mobility}

To examine the effect of client-specific investments on auditor mobility (hypothesis 12), only mobility within Big Six and within non-Big Six firms is considered. As suggested in paragraph 3.3.3.3, this selection filters out possible confounding effects of up-or-out promotion systems and audit quality differences between large and small audit firms. To test for the influence of client-specific investments, piecewise constant exponential models were specified for the transitions of auditors moving between Big Six firms and auditors moving between non-Big Six firms.

The transition rate functions for auditors moving within Big Six audit firms and for auditors moving within non-Big Six audit firms are presented in FIGURE 6. An examination of these transition rates reveals that the probability of within Big Six mobility is moderately low in all years of job tenure and clustered in the early career stages. Within non-Big Six mobility is higher and more dispersed over the career history. This difference in level of transitions might be interpreted as evidence of a difference in firm-specific capital between large and small audit firms. Furthermore, the pattern of within Big six mobility is in line with human capital theory, which not only predicts that firm-specific capital reduces mobility, but also predicts that if mobility occurs, it will take place in the early career stages where levels of firm-specific capital are still relatively low.

The coefficient estimates and the annual transition rates of the piecewise constant exponential models for within Big Six and Within non-Big Six mobility are shown in TABLE 7. In all periods, the within non-Big Six firm mobility rates are higher than (or in the later years of job tenure equal to) the within Big Six firms rates. A paired samples t-test indicates that this difference is significant at the 0.01 level (t-value $=7.045, p=0.001$ ). Apparently, firm-specific capital, which makes auditors more productive at the current firm, but has no effect on productivity elsewhere, reduces the likelihood of turnover of Big Six auditors. These results confirm hypothesis 12 , implying that client-specific investments reduce the inter-organizational of auditors.

Moreover, TABLE 7 shows that the coefficient estimates for the covariates education and promotion to partner are statistically significant (at the 0.05 level) and act in the expected direction in both models. The coefficient estimate for firm founder is only significant (at the 0.01 level) for within non-Big Six firm mobility, which could be expected since only non-Big Six auditors qualify as firm founders. Furthermore, a positive effect of age at qualification was only significant (at the 0.05 level) for within Big Six firm mobility, and positive effects of date of qualification and previous jobs was only statistically significant (at the 0.05 level) 
for within non-Big Six mobility. However, most coefficient estimates for these two types of moves confirm the results of the general model of interorganizational mobility.

\section{FIGURE 6}

Transition rate functions for auditors

moving within Big Six audit firms and within non-Big Six audit firms

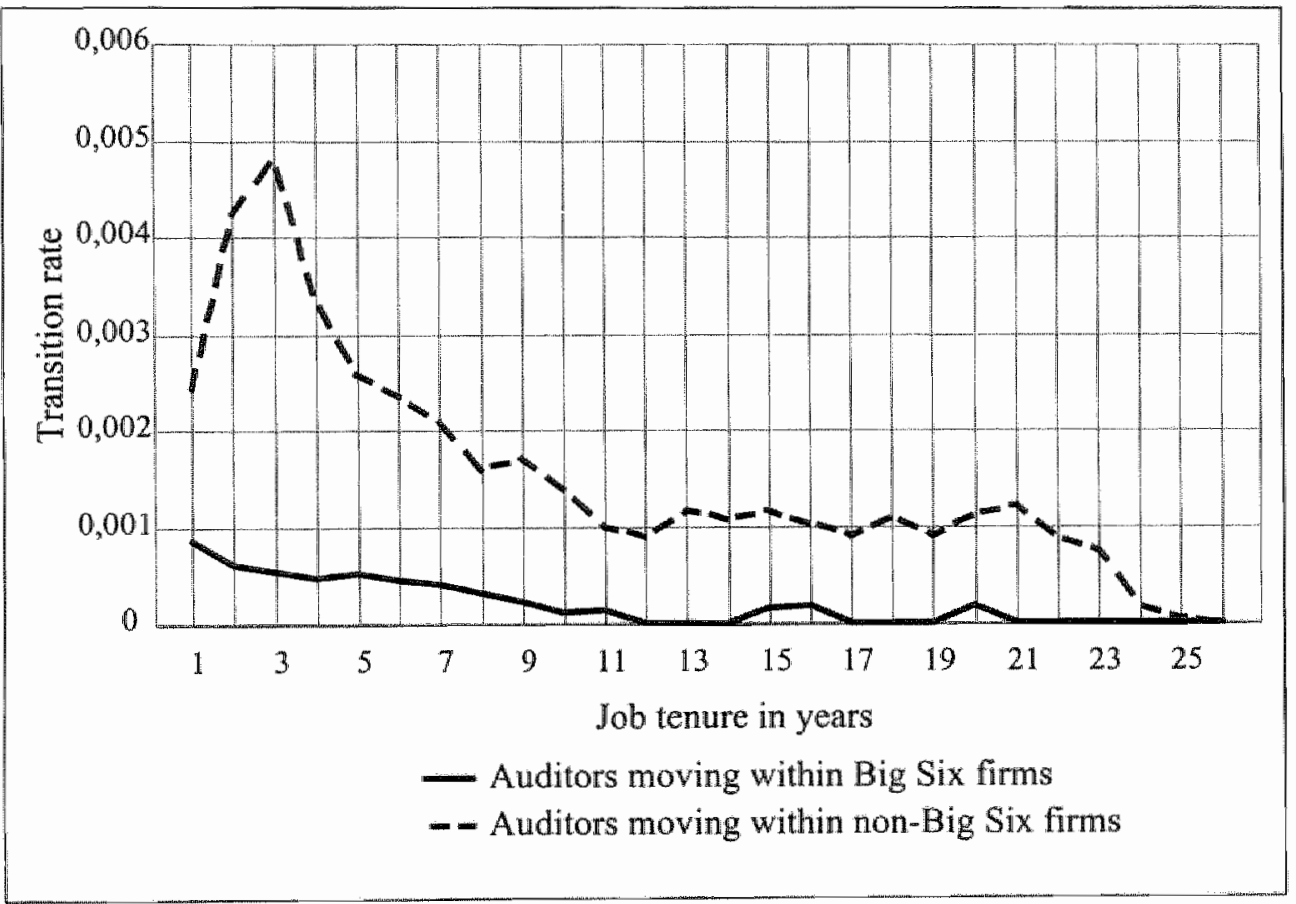




\section{TABLE 7}

The effect of client-specific investments on inter-organizational mobility:

Coefficient estimates and transition rates

of within Big Six firm and within non-Big Six firm mobility.

\begin{tabular}{|c|c|c|c|c|c|c|}
\hline Variables & $\begin{array}{l}\text { Within Big } \\
\text { Coefficient }\end{array}$ & $\begin{array}{l}\text { Six fir } \\
\text { Prob. }\end{array}$ & $\begin{array}{l}\text { mobility } \\
\text { ransition } \\
\text { rate }^{b_{1} c}\end{array}$ & $\begin{array}{l}\text { Within non- } \\
\text { Coefficient }\end{array}$ & Prob. & $\begin{array}{c}\text { mobility } \\
\text { Transition } \\
\text { rate }^{\text {b.c }}\end{array}$ \\
\hline Period-1 & -7.111 & 0.000 & $1.0 \%$ & -6.017 & 0.000 & $2.9 \%$ \\
\hline Period-2 & -7.451 & 0.000 & $0.7 \%$ & -5.459 & 0.000 & $5.1 \%$ \\
\hline Period-3 & -7.511 & 0.000 & $0.7 \%$ & -5.295 & 0.000 & $6.0 \%$ \\
\hline Period-4 & -7.598 & 0.000 & $0.6 \%$ & -5.677 & 0.000 & $4.1 \%$ \\
\hline Period-5 & -7.531 & 0.000 & $0.6 \%$ & -5.937 & 0.000 & $3.2 \%$ \\
\hline Period-6 & -7.640 & 0.000 & $0.6 \%$ & -6.034 & 0.000 & $2.9 \%$ \\
\hline Period-7 & -7.785 & 0.000 & $0.5 \%$ & -6.166 & 0.000 & $2.5 \%$ \\
\hline Period-8 & -8.005 & 0.000 & $0.4 \%$ & -6.430 & 0.000 & $1.9 \%$ \\
\hline Period-9 & -8.338 & 0.000 & $0.3 \%$ & -6.357 & 0.000 & $2.1 \%$ \\
\hline Period-10 & -8.943 & 0.000 & $0.2 \%$ & -6.561 & 0.000 & $1.7 \%$ \\
\hline Period-11 & -8.874 & 0.000 & $0.2 \%$ & -6.923 & 0.000 & $1.2 \%$ \\
\hline Period-12 & -14.258 & 0.345 & $0.0 \%$ & -6.979 & 0.000 & $1.1 \%$ \\
\hline Period-13 & -14.258 & 0.355 & $0.0 \%$ & -6.746 & 0.000 & $1.4 \%$ \\
\hline Period-14 & -14.258 & 0.367 & $0.0 \%$ & -6.811 & 0.000 & $1.3 \%$ \\
\hline Period-15 & -8.707 & 0.000 & $0.2 \%$ & -6.769 & 0.000 & $1.4 \%$ \\
\hline Period-16 & -8.636 & 0.000 & $0.2 \%$ & -6.831 & 0.000 & $1.3 \%$ \\
\hline Period-17 & -14.258 & 0.408 & $0.0 \%$ & -7.010 & 0.000 & $1.1 \%$ \\
\hline Period-18 & -14.258 & 0.435 & $0.0 \%$ & -6.770 & 0.000 & $1.4 \%$ \\
\hline Period-19 & -14.258 & 0.467 & $0.0 \%$ & -7.023 & 0.000 & $1.1 \%$ \\
\hline Period-20 & -8.113 & 0.000 & $0.4 \%$ & -6.797 & 0.000 & $1.3 \%$ \\
\hline Period-21 & -14.258 & 0.547 & $0.0 \%$ & -6.602 & 0.000 & $1.6 \%$ \\
\hline Period-22 & -14.258 & 0.594 & $0.0 \%$ & -7.003 & 0.000 & $1.1 \%$ \\
\hline Period -23 & -14.258 & 0.644 & $0.0 \%$ & -6.824 & 0.000 & $1.3 \%$ \\
\hline Period-24 & -14.258 & 0.693 & $0.0 \%$ & -12.322 & 0.490 & $0.0 \%$ \\
\hline Period-25 & -114.258 & 0.751 & $0.0 \%$ & -12.322 & 0.579 & $0.0 \%$ \\
\hline Period-26 & -14.258 & 0.788 & $0.0 \%$ & -12.322 & 0.587 & $0.0 \%$ \\
\hline Education & 0.635 & 0.023 & & 0.341 & 0.003 & \\
\hline Age at qualification & -0.088 & 0.029 & & 0.014 & 0.271 & \\
\hline Promotion to partner & $r=1.667$ & 0.000 & & -1.263 & 0.000 & \\
\hline Finm founder & -8.120 & 0.912 & & -0.601 & 0.000 & \\
\hline Date of qualification & n 0.459 & 0.105 & & 0.403 & 0.000 & \\
\hline Previous jobs & 0.012 & 0.967 & & 0.131 & 0.035 & \\
\hline
\end{tabular}

a For this estimation, 26 time periods were defined of one year each. The time periods are based on job tenure, which is defined as the time in a job.

- The transition rate is presented percentages per year.

" The t-value for paired samples for the effect of client-specific investments on the within sector mobility rates of Big Six and non-Big Six firms is 7.045 (26 df, $p=0.001$ ). 


\subsection{Summary and conclusions}

By using event history models to examine the inter-organizational mobility of 13 annual cohorts of auditors, this chapter provided evidence on the total interorganizational mobility of auditors, and on the consequences of client-specific investments, the existence of audit quality differences, and the use of up-or-out promotion systems. A piecewise constant exponential model, including personal and organizational variables, was estimated for the total transition rate function, and provided evidence on the non-monotonic relationship between job-tenure, work experience and inter-organizational auditor mobility. After an initial 'honeymoon'-period of about 3 years in which mobility sharply increases, auditor mobility starts to decrease gradually. Auditors who have not experienced mobility after 10 to 15 years only have a very low probability to move. Furthermore, the results show that education is positively related to auditor mobility. That is, university graduates with a broader education are more likely to experience mobility than non-university educated auditors. The probability of interorganizational auditor mobility decreases with a promotion to partnership and with the founding of an audit firm. Apparently, after promotion to partner or after the founding on one's own audit firm, careers become in a steady phase. Evidence is also provided on the fact that auditors are more likely to experience mobility if they qualified as auditors in more recent years. The increased competition over time in the Dutch audit market especially influenced the later cohort as these auditors were still early in their careers and therefore had more opportunities to change employer. Inconclusive evidence is found on the influence of the auditor"s age at qualification and the number of previous jobs. The age at qualification is negatively related to the total hazard rate, but the specific tests indicated that this only holds for certain types of moves. The number of previous jobs was not significantly related to the total hazard rate.

Furthermore, the results on the model of total inter-organizational mobility are inconclusive with respect to the association between audit firm size and total inter-organizational mobility. Probably because of the simultaneous influences of client-specific investments, audit quality and up-or-out systems. Therefore, specific tests were conducted on the influence of the variables on the nature of inter-organizational mobility. A distinction was made between three types of employment: Big Six audit firms, non-Big Six audit firms and business/government. In this way, the separate effects of client-specific investments, audit quality and up-or-out promotion systems could be identified, which enabled the investigation of these three factors from a mobility perspective. In particular, the evidence suggests that auditor specialization, which leads to 
more client-specific human capital, is negatively related to auditor mobility. This indicates that human capital is closely associated with the production of audit services. Audit firms trying to obtain economies of scale by specializing in certain industries or stimulate client-specialization by requiring auditors to specialize in certain types of clients, reduce the mobility opportunities of their auditors. However, this is to a large extent offset by the better opportunities auditors have if they are employed with a high quality firm. That is, the results also show that large audit firms provide a higher level of audit quality as compared to small audit firms, given the finding that upward auditor mobility is significantly lower than downward auditor mobility. An implication of this finding is that audit quality differences between audit firms are also reflected by reputations of individual auditors. Furthermore, up-or-out promotion systems are more frequently used by large audit firms than by small audit firms, creating additional mobility out of large audit firms. As expected, small audit firms have less incentives to maintain up-or-out promotion systems than large audit firms. Size restrictions prevent them from using these type of promotion systems.

The current study differs from previous studies on auditor mobility in that it uses event history analysis to examine the process of auditor mobility while the influence of both personal and organizational variables on actual auditor mobility is tested. Furthermore, instead of using audit fees or client-portfolio information, this study addresses 'traditional' auditing issues, such as client-specific investments and audit quality differences, from an auditor mobility perspective. This study acknowledges that audit services are delivered by individual auditors and that they experience quality differences and the effects of client specialization. In other words, this opens up the 'Black Box' of audit firms. While previous research viewed audit firms as single entities, this research starts from the notion that audit firms are groups of individual auditors. Hence, this research provides insights into the functioning of audit firms, and enables the examination of auditing phenomena from a different perspective: the individual auditor.

In this respect many interesting issues for further research emerge. First, future research could collect additional data on auditor mobility to provide a more detailed view of the mobility process. This would include data on salary structures and evaluations of auditors, which provides more insight into whether moves are voluntary or involuntary. Such information would benefit the analysis of clientspecific investments, the existence of audit quality differences between firms and the use of up-or-out promotion systems significantly. Also, by examining client 
portfolios of individual auditors, future research could provide insight into the effects of client-specific investments in up-or-out decisions. It can be argued that auditors who possess a high level of firm-specific human capital, will move to clients to retain their client-specific investments when they need to leave the firm after a negative partner decision. Moreover, future studies could use industryrelated variables, such as information on audit market structure and economic conditions to investigate whether the current results on auditor mobility hold, or whether firms are still inclined to use up-or-out promotion systems, in for example a growing market when the demand for audit services is high and thus many auditors are needed.

Furthermore, future studies could conduct specific analyses on the rellationship between mobility and type of organization. In this respect, a link could be made with internal labour markets. Which types of firms predominantly use their internal labour market to staff positions and which types of firms staff through lateral entry? Also, it can be tested if the current results hold when individual firms are analysed. Maybe, there are differences between Big Six firms with respect to the acquisition of client-specific human capital, or are there differences in up-or-out policies? These analyses would then also give more insight in the management of audit firms. 


\section{Chapter 4 \\ Competition in audit markets}

Tilis chapter investgates the isefulness of a dynamu analysis of adoll

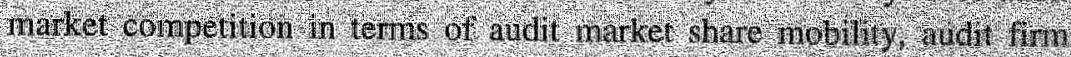
enty, ard audi fim exit These dynamic neasures of matket struenire are eompared between the nore reguated Belgian and Germinn and Tharkers and Lie nore liberal Duch audit narket. Prior reseatch on audit market stutucture has focussed on slatie analyses in terms of seller coneentration of single national audit narkets. By using data on the number of aiditns as he neasure of audit firm size his analysis covers all fims active in the three audit mirkets in the period 1970 to 1994 . The results thdieare that he more liberal Dutch audit narket has we bighest dynamie measures of market stucure and ine hitgliest concentration. Henee, the tesuls s low that high conceentration can go hand in hand with high natket share nobility, and high audit fun eniry and exit. The rosiuts for naiket share nobility also hold for an ainalysis only nelinding lie largest audit finns. The chapter therefore concludes that compared with a statie seller concentration analysis, an analy sis of audit narkel dynamies provides a betiet descriplion of the degree of competiton in audil markels:

\subsection{Introduction}

A large number of papers on seller concentration in audit markets have appeared since the pioneering study of Zeff and Fossum (1967). Recent papers in this area of research show that there is a continuing interest in this topic [see, e.g. Pearson and Trompeter (1994); Johnson, Walker and Westergaard (1995); Peel (1997); and Doogar and Easley (1998)]. This interest can be explained by concerns that

\footnotetext{
This chapter is based on Buijink, Maijoor and Meuwissen (1998).
} 
the audit market is not competitive. The recent merger between the two Big Six firms Coopers \& Lybrand and Price Waterhouse has actually been investigated by the European Commission and resulted in concerns about high seller concentration in the audit market.

A common interpretation of the degree of seller concentration in a market is that it determines the degree of competitive pricing in a market [see Carlton and Perloff (1994, chapter 9)]. This interpretation provides a major motivation for the measurement of seller concentration in audit markets [see, e.g. Dopuch and Simunic (1980); Moizer and Turley (1989)]. ${ }^{2}$ Most of the empirical audit market structure literature measures seller concentration at given points in time and one of the general findings is that there is a significant level of auditor concentration that is fairly stable over time. This high and stable concentration, however, seems inconsistent with the views expressed by the profession that audit markets are currently very competitive.

There is theoretical justification for a relationship between seller concentration and the ability of sellers to raise prices above the competitive level in a static context [see, e.g. Schmalensee (1982, section 2); Clarke (1985, chapter 3)]. It can be questioned, however, whether this justification is valid in a dynamic setting [Baldwin and Gorecki (1989); and Mueller (1991)]. Once one imagines markets evolving over time, necessitating the consideration of intra-industry market share mobility, and entry and exit, hypotheses about pricing-behaviour based on static reasoning become suspect. Hence, measurement of seller concentration at a point in time or a comparison of seller concentration between two points in time is not helpfull in inferring the strength of competition or rivalry among firms. High concentration measures for a market do not exclude the possibility of considerable changes in the size distribution of firms, the number of firms, and the identity of leading firms. To give an extreme example, in the case of a market that is a monopoly in multiple periods, the typical static concentration measures will have at all points in time a maximum value. However, these

${ }^{2}$ Dopuch and Simunic $(1980$, p. 78$)$ describe this interpretation in the context of audit markets: "The uswal argument is simply that the more concentrated an industry becomes, the easier it is for firms which account for the bulk of the industry's sales to collude in setting prices, allocating markets ...". In a UK audit market seller concentration paper by Moizer and Turley (1989, p. 41), this argument is used to motivate the research: "The level of supplier concentration (in an audit market) is of interest because it is likely to be an important determinant of audit firms" behavior. The level of supplier concentration is usually associated with an oligopolistic market where supply is dominated by a small number of large firms. ... The most usual form (of behavior) will be an agreenent to avoid price competition.". 
measures would not register the possibility that in every time period the incumbent monopolist is replaced by a new monopolist.

There are at least three arguments for capturing the strength of inter-firm rivalry in a market by studying the extent of intra-industry market share transfers between continuing firms and firm entry and exit. ${ }^{3}$ First, presumably market share transfers between continuing firms as well as entry and exit form the mechanism that results in the erosion of supra-competitive profit levels. As Schmalensee (1989, p. 999) states: "While stable market shares and firm ranks are consistent in principle with either collusion or competition, most would argue that unstable shares and ranks are inconsistent with effective collusion." Second, previous studies have shown that there is no direct relationship between concentration measures and dynamic measures of market structure. Concentration measures conceal many of the dynamic processes in markets [Davies and Geroski (1997)]. Finally, market share instability is used in the industrial organization literature to measure firm rivalry [see, e.g. Gort (1963); Caves and Porter (1978); Eckard (1987); Sandler (1988); and Baldwin and Gorecki (1989)].

In addition to neglecting market dynamics, a problem with most of the existing literature on audit market structure is that audit firm size is measured by cumulative client size, measured in various ways, for a given group of clients. Because data on smaller clients is difficult to obtain, most papers automatically focus on larger clients and as a consequence on larger audit firms. This leads to a truncated audit firm sample and produces upward-biased seller concentration measures of audit markets [see Tomczyk and Read (1989, pp. 103-104)].

In this chapter both problems are addressed. It provides a dynamic description of the structure of the complete Belgian, Dutch, and German audit markets between 1970 and 1994. Comparing the audit market structures of these three countries is useful since their regulatory regimes vary. The Dutch audit market regulation is, compared to the Belgian and German regulatory regimes, more pro-competitive. This provides the opportunity to assess the regulatory influence on the competitive processes in these markets and to empirically validate this by presenting detailed results on seller concentration, market share mobility and audit firm entry and exit.

Data on the number of auditors are used as the measure of audit firm size. These data are readily available in the three countries under study, and this creates the possibility to obtain detailed results about the dynamic characteristics of complete audit markets. Moreover, as will be discussed below, this firm size

${ }^{3}$ In the audit market structure literature, this point was emphasized in Dopuch and Simunic $(1980$, pp. $81-82)$ 
measure correlates highly with (audit) fee-income. The audit firm size data are constructed from the membership lists which were published from 1970 to 1994 by the three professional organizations of auditors in the three countries under study: the Institut des Reviseurs d'Entreprises/Instituut der Bedrijfsrevisoren in Belgium, the Wirtschaftspriferkammer in Germany, and the Koninklijk Nederlands Instituut van Registeraccountants in the Netherlands. In Belgium, Germany, and the Netherlands the right to attest the financial statements of firms is restricted by law to the members of these three organizations. ${ }^{4}$ Hence, members of the three professional organizations, or the firms to which they belong, form the complete audit markets in the three countries studied.

The chapter proceeds as follows. The next section discusses relevant previous empirical research on audit markets. Section 4.3 discusses the static and dynamic measures of audit market structure that are used in this chapter. Section 4.4 describes the three countries' regulatory characteristics and their potential effects on audit market competition. Section 4.5 presents the audit firm size surrogate and discusses the data used. Section 4.6 presents the results of the static and dynamic analyses of audit market structure. Finally, section 4.7 gives a summary and conclusions.

\subsection{Previous research}

There are quite a few studies that measure seller concentration in audit markets [see, e.g. Zeff and Fossum (1967); Gilling and Stanton (1978); Eichenseher and Danos (1981); Danos and Eichenseher (1986); Tomczyck and Read (1989); and Peel (1997). The early studies measured the four-firm and eight-firm concentration ratio at one point in time [Zeff and Fossum (1967), Rhode, Whitsell and Kelsey (1974); and Schiff and Fried (1976)]. Gilling and Stanton (1978) introduced the more advanced Hirschman-Herfindahl-Index as a measure of seller concentration in the audit market literature. ${ }^{5}$ Gilling and Stanton (1978) were also

${ }^{4}$ Both in Germany and the Netherlands there is also a professional body of second tier auditors. However, they mainly provide compilation and tax services to smaller clients. In Germany they are called vereidigle Buchprifer and since 1985 they have the right to conduct audits for smaller clients. In the Netherlands, they are called Accowntants-Administratieconsulenter. Only since 1993 a part of their membership is allowed to conduct audits. For a more elaborate overview of the right to conduct (statutory) audits, see the overviews of the Belgian, German and Dutch auditing professions in Appendix A.

See paragraph 4.3.4 for an explanation of the Hirschman-Herfindahl-Index. 
the first to measure seller concentration in more than one year. Thereafter, most concentration studies presented seller concentration statistics for several points in time [see, e.g. Dopuch and Simunic (1980); Campbell and McNiel (1985); Danos and Eichenseher (1986); Tomczyck and Read (1989); Christiansen and Loft (1992); Beattie and Fearnley (1994); Pearson and Trompeter (1994)].

Previous studies only include a subset of all firms supplying services in the audit market. That is, onlly firms that audit larger companies are included, because to measure audit firm size most studies use client data (i.e. assets, revenues, market value and number of clients). And these client data in combination with the name of the incumbent auditor were in general only available for larger and/or listed companies. Some of the more recent studies measure audit firm revenue directly, but again for a truncated sample of audit firms [Moizer and Turley (1989); Tomczyk and Read (1989); Zind and Zéghal (1989); Johnson, Walker and Westergaard (1995); Iyer and Iyer (1996); and Peel (1997)]. Only the study by Maijoor, Buijink, van Witteloostuijn and Zinken (1995) on the development of the structure of the Dutch audit market uses the number of professionals as a proxy for audit firm size and therefore captures the complete Dutch audit market.

A typical result, if seller concentration is measured in two or more years, is that concentration levels are substantial and fairly constant over time [see, e.g. Gilling and Stanton (1978); Dopuch and Simunic (1980); Tomczyck and Read (1989); and Pearson and Trompeter (1994)]. Only those studies analysing the effects of the 1989 mergers within the Big Eight audit firms on the level of concentration in the market for audit services observe an increased concentration after the mergers [see, e.g. Tonge and Wootton (1991); and Iyer and Iyer (1996)]. Furthermore, some of the more recent papers on audit market structure measure the effect of supplier concentration on audit fees but their results are mixed. Pearson and Trompeter (1994) found that higher levels of concentration are associated with lower audit fees, whereas Johnson, Walker and Westergaard (1995) reported opposite results. Iyer and Iyer (1.996) found no significant evidence of an association between levels of concentration and audit fees. A different approach was taken by Doogar and Easley (1998), who attempted to explain audit market concentration and found that the number of partners, the staff-to-partner ratio, and the distribution of client sizes determine Big Six firms" actual market shares. However, they use client data to measure audit firm market shares and their analyses only apply to a truncated sample of large audit firms.

Most of the previous studies on audit market concentration implicitly suggest that high and stable concentration levels indicate limited competition. But as pointed out earlier, stable and high seller concentration can be observed both when no market shares are transferred over time between audit firms and when 
substantial market shares are transferred. Hence, high and stable concentration is consistent with both weak and stiff competition. The previous studies neglect the latter situation where stable and high concentration levels go hand in hand with substantial market share mobility. Therefore, they most likely understate the level of competition. Such an understatement is potentially aggravated by the use of restricted audit firm samples. To remedy this provides the main motivation for the present study.

There also exist a number of papers that attempt to test the hypothesis of noncompetitive pricing in an audit market directly [see, e.g. Simunic (1980); Francis (1984); Palmrose (1986); Ettredge and Greenberg (1990); O'Keefe, Simunic and Stein (1994); and Craswell, Francis and Taylor (1995)]. In general, these studies test for audit price differences between Big Eight (Six) and non-Big Eight (Six) audit firms. The hypothesis is that the market for large auditees, with only a few suppliers, is not competitive. On the other hand, the market for small auditees, with a large number of supplying audit firms, is assumed to be competitive. The results of the pricing studies are mixed. Some of the conflicting results can be attributed to differences in research design [see Francis and Stokes (1986)]. A more fundamental problem is that price differences do not necessarily have implications for the competitiveness of the audit market. Other factors, such as differences in audit quality, might also cause price differences between large and small audit firms. Differences in audit fees found can both be the result of a competitive market with non-price rivalry, and a not competitive market with no quality differences. To distinguish between these two competing explanations is difficult [see, e.g. Palmrose (1986, p. 108)]. It is of interest therefore to note that the research method applied in this study does not need to distinguish between the two competing explanations. Actual transfers of market shares may both be the result of price and non-price rivalry [see Sandler (1988, p. 327)].

There are many industrial organization studies on the market structure of other industries [for an overview, see, e.g. Curry and George (1983)]. In the empirical part of that literature, there is a long tradition of measuring static seller concentration [see, e.g. Weiss (1989)]. In more recent years, however, studies have appeared that empirically investigate the dynamics of market structure, including market share mobility and entry and exit. Especially relevant for the present study are the studies by Dunne, Roberts and Samuelson (1988), Baldwin and Gorecki (1991), Baldwin and Gorecki (1994), Baldwin (1995), and the contributions in Geroski and Schwalbach (1991).

Although in industrial organization dynamic analyses of market structure are quite common, in the audit market literature, only three studies provide some indication of incumbent firm market share mobility [Moizer and Turley (1989); 
Danos and Eichenseher (1982); and Danos and Eichenseher (1986)]. Moreover, none of the audit market studies provides detailed data on audit firm entry or exit.

\subsection{Measures of market structure}

\subsubsection{Introduction}

The measures of market structure used in this study are not only based on the traditional static measures of market structure, but also on the actual transfers of market shares between continuing, entering, and exiting firms. As remarked earlier, the actual transfers of market shares are not conveyed in the static seller concentration measures, because of their focus on the distribution of market shares at one point in time. This section will first introduce the measure of market share mobility in paragraph 4.3.2. After that, the dynamic measures of entry and exit will be presented in paragraph 4.3.3. Finally, in paragraph 4.3 .4 the static measures of market structure will be discussed.

\subsubsection{Measure of Market Share Mobility}

To measure market share mobility among continuing firms (MOB), a measure suggested by Baldwin and Gorecki (1989) will be used. The measure is directly based on individual market share changes of continuing firms in a given period:

$$
\operatorname{MOB}(t)=\frac{\sum_{\mathrm{i}=1}^{\mathrm{N}}\left|s h_{\mathrm{it}}-s h_{i d}\right|}{2}
$$

where $s h_{i 0}$ is the market share of an audit firm $i$ at time zero and $s h_{i t}$ is the market share of the same firm at time t. The total number of continuing firms in the market is $\mathrm{N}$. MOB measures the amount of market share switching between audit firms for a given period. As a result it can have a value between $0 \%$ and $100 \%$ [see, Baldwin and Gorecki (1989, p. 322)]. ${ }^{6} \mathrm{MOB}$ will be calculated for all continuing audit firms, and for a subset of the largest continuing audit firms.

- MOB is based on a measure of market share mobility developed earlier by Hymer and Pashigian (1962). They suggested the numerator of MOB as a measure of market share instability. Other dynamic measures of market structure exist, but are not used in this study [see, e.g. Shorrocks (1978), Sandler (1988)]. 


\subsubsection{Measures of Entry and Exit}

The summary measures of entry and exit used, are based on the following variables [see, e.g. Dunne, Roberts and Samuelson (1988), Baldwin and Gorecki (1991)]:

$\mathrm{NE}(\mathrm{t})=$ number of firms that enter the audit market between time $\mathrm{t}-1$ and $\mathrm{t}$;

$\mathrm{N}(\mathrm{t})=$ total number of firms in the audit market at $\mathrm{t}$. This includes firms that enter the audit market between $\mathrm{t}-\mathrm{l}$ and $\mathrm{t}$; and

$\mathrm{NX}(\mathrm{t})=$ number of firms that exit the audit market between $\mathrm{t}-1$ and $\mathrm{t}$.

The total entry rate in number of firms (TER), and the total exit rate in number of firms (TXR) for the period between $t-1$ and $t$ are defined as:

$\operatorname{TER}(\mathrm{t})=\mathrm{NE}(\mathrm{t}) / \mathrm{N}(\mathrm{t})$

$\operatorname{TXR}(t)=N X(t) N(t-1)$

Hence, entry is calculated as a proportion of the total number of firms in the audit market at $t$, and exit is calculated as a proportion of the total number of firms in the audit market at $t-1$.

The entry and exit rates can be subdivided. The entry rates can be split into two rates: (1) the rate of entry of audit firms established by auditors who leave existing audit firms (AER), and (2) the rate of entry of audit firms established by auditors previously not active in the audit industry (LER). This can either be auditors who leave a position in business or government, or auditors who just received their license.

The exit rates can be subdivided into two methods of exit: (1) exit can be the result of mergers between audit firms (MXR), and (2) exit can be the result of 'pure' exit (PXR). Examples of the latter category are when all partners of an audit firm decide to leave the audit industry for a position in business or when all partners retire. More detailed information on defining the different methods of entry and exit is given in Appendix B. Finally, it should be remarked that the entry and exit rates, both in terms of number of firms, will be reported as percentages.

The entry and exit rates subdivided as AER and MXR can in some sense be considered superior indicators of competition in the market compared to LER and PXR. Regarding entry, the size of cohorts of accountancy students will have a 
substantial impact on LER. ${ }^{7}$ Regarding exit, the age distribution of auditors in smaller audit firms will have a substantial impact on PXR as the effects of retirement are included in this measure.

\subsubsection{Static measures: the Concentration Ratio $C_{n}$ and the Hirschman- Herfindahl Index}

For comparison with the dynamic measures of market structure, market share mobility and entry and exit, this study also presents results for the traditional static market structure measures. Common measures are the concentration ratio $\mathrm{C}_{\mathrm{n}}$ and the Hirschman-Herfindahl index $\left(\mathrm{H}\right.$-index). ${ }^{8}$

The $\mathrm{n}$ firm concentration ratio in an $\mathrm{N}$ firm audit market at a given moment in time with the $\mathrm{N}$ firm ranked in order of decreasing size, is defined as,

$$
\mathrm{C}_{\mathrm{n}}=\sum_{\mathrm{i}=1}^{\mathrm{n}} \mathrm{sh}_{\mathrm{i}}
$$

where $s h_{i}$ is the market share of firm $i$. That is, $C_{n}$ is the cumulative market share of the $n$ largest of the $\mathrm{N}$ firms in the audit market. Note that $\mathrm{C}_{\mathrm{n}}$ does not capture the whole firm size distribution. Market share information of firms smaller than firm $n$, is not conveyed in the measure. Common values for $\mathrm{n}$ are four and eight.

The $\mathrm{H}$-index does give a characterization of concentration in the complete industry firm-size distribution. $\mathrm{H}$ is defined, again for an $\mathrm{N}$-firm audit market, as

$$
H=\sum_{i=1}^{N}{s h_{i}^{2}}^{2}
$$

That is, $\mathrm{H}$ is the sum of the squared market shares of all the firms in the audit market at a given moment in time. The $\mathrm{H}$-index is a weighted sum of market shares, where the weights are the market shares themselves. This weighing scheme means that

\footnotetext{
${ }^{7}$ It should be noted that hiring policies of large audit firms will allso affect the LER measure. The more aggressively large existing firms hire from a new cohort of licensed auditors, the less new licensees will consider to start their own audit firm. Hence, LER is both influenced by current hiring policies and by past decisions of students. It should also be noted that increased hiring of newly licensed auditors will be reflected in one of the other dynamic measures: MOB More hiring of newly licensed auditors will increase the size of the audit firm, and will subsequently increase the market share of the audit firm.

${ }^{8}$ Other measures of concentration exist [see Curry and George (1983)]. But like the literature surveyed in section 4.2 , this study will use $C_{\mathrm{n}}$ with $n=4$, and the $H$-index.
} 
smaller firms will influence the $\mathrm{H}$-index to a lesser extent than larger firms. The $\mathrm{H}$ index is both sensitive to the total number of firms in the market and the dispersion of market shares. However, because of the earlier mentioned data restrictions, all previous seller concentration studies of audit markets only include a subset of the total audit firm population in their $\mathrm{H}$-index calculations. Finally, it should be noted that both the concentration ratio $\mathrm{C}_{\mathrm{n}}$ and the $\mathrm{H}$-index do not convey information on changes in individual market shares of continuing firms, or on entry and exit.

\subsection{Regulation and competition in the Belgian, German and Dutch audit markets}

\subsubsection{Introduction}

In this section predictions are developed about the variation in the extent of rivalry between firms in Belgian, German and Dutch audit markets. The variation in rivalry, or competition, can be expected to be reflected in the dynamic measures of audit market structure. High market share mobility and high audit firm entry and exit indicate stiff competition. The predictions will be based on national audit market regulations that can be expected to affect competitive conduct. A condition for the usefulness of data from the three national markets in testing hypotheses about differences in audit market competition is that there are barriers preventing crosscompetition and cross-entry between national markets. For two main reasons these barriers exist [see European Commission (1996)]. First, national barriers are erected because of licensing regimes, and restrictions on the foreign ownership and foreigm management of audit firms. Second, cross-competition and cross-entry between audit markets are difficult because of country-specific auditing knowledge required to conduct audits. The existence of country-specific auditing knowledge is for example the result of national differences in business practices, business laws, social security systems, and tax regimes.

With respect to the three audit markets covered in this study, the major international audit firm networks are represented in all three markets and some of the largest companies in the world are clients of audit firms in the three countries. Examples are the Belgian companies Agfa-Gevaert and Petrofina, the German companies Daimler-Benz, Deutsche Bank, Siemens, and Volkswagen, and the Dutch companies ABN-Amro, Philips, Shell, and Unilever. As will be discussed later, on broad indicators, the Belgian audit market is quite small and the German and the Dutch audit markets are of about equal size. These last two markets are for example larger than the Australian and Canadian audit markets. 
To formulate predictions on the extent of rivalry, this section focuses on a set of three specific competition and entry impeding regulations in the context of audit markets. First, paragraph 4.4 .2 discusses the professional entry requirements. Secondly, restrictions on advertising and solicitation are analysed in paragraph 4.4.3. Thirdly, paragraph 4.4 .4 describes the restrictions on the services that auditors are allowed to provide. Finally, paragraph 4.4 .5 presents the conclusions of this regulatory analysis. The description of these three forms of auditing regulation applies to the period of study 1970-1994. For a more elaborate overview of the regulatory regimes of the auditing professions in Belgium, Germany and the Netherlands see Appendix A.

\subsubsection{Professional entry requirements}

The entry barrier to qualification is lower in the Netherlands than in Belgium or Germany. The major difference among the three countries is that Belgium and Germany have a practical experience requirement during the period of study. Hence, obtaining a license as an auditor in Belgium requires a minimum of three years and in Germany a minimum of five years of professional experience. Furthermore, because of their practical experience requirement, Belgium and Germany require candidates to first attain a traineeship before starting the educational programme. Such requirements can be expected to impede entry to the profession. An important difference is also that in Belgium and Germany auditors are required to maintain sufficient up-to-date experience through a requirement to carry out minimum levels of auditing. In the Netherlands auditors stay qualified even when not in public practice. Considering all this, it can be concluded that Belgium and Germany have stricter entry requirements than the Netherlands.

Furthermore, the following data support the assumption that entry to the profession in Belgium and Germany is difficult. First, a FEE (1988) study reports that of the 17 European countries covered, Germany has the highest age of qualification (i.e. 35 years). Second, Morse (1993) has scaled the number of auditors active in audit markets by the size of the national population. The ratio for the Netherlands is about 6.5 times higher than the Belgian ratio and about 4.5 times higher than the German ratio."

"According to Morse (1993), the Netherlands has 450 auditors per 1 million inhabitants, whereas Belgium and Germany only have 69 respectively 96 auditors per 1 million inhabitants. 


\subsubsection{Restrictions on advertising and solicitation}

Restrictions on advertising and solicitation influence the nature of competition in an audit market, since for example new entrants to the market will have more difficulty to establish a reputation and/or a brand name. This will make it more difficult for entrants to compete with incumbent audit firms.

In terms of advertising, the Dutch audit market is far more liberal. All advertising is allowed as long as it complies with professional ethics. In Belgium and Germany, in principle, all advertising is forbidden, although in Belgium advertising on a local scale, if factual and objective, is permitted. In both countries auditors may only provide the name of their firm in academic articles, speeches, and seminars. Direct solicitation is not allowed in all three countries.

\subsubsection{Restrictions on auditor services}

Compared with the Netherlands, in Belgium and Germany offering services other than auditing is more difficult for auditors. At the individual level, Belgian and German auditors have a continuing professional experience requirement. They need to maintain a minimum level of auditing hours each year. Hence, Belgian and German auditors will lose their license when becoming employed outside the auditing profession. At the level of audit firms, both in Belgium and Germany it is not allowed to provide bookkeeping services to audit clients. In the Netherlands, there is no professional experience requirement, and audit firms are allowed to provide bookkeeping services to audit clients.

With respect to the appointment procedure of auditors, one of the main differences among the three countries is the length of the appointment. In Belgium, the length of the appointment of the auditor is a fixed period of three years, whereas in Germany and the Netherlands there is no regulation on the length of the appointment. Regulations that specify a (long) period of appointment can be expected to impede competition between audit firms, since auditees are not able to change auditors within that specified period.

Furthermore, audit fee regulations, which also can be expected to affect competitive conduct, differ among the three countries under study. Overall, regulations in this area attempt to prohibit or restrict low balling. Of the three countries covered, only in Belgium auditors are required to report the number of hours and the fee for an audit to the professional body, which reviews the adequacy of both figures. Although all three countries require that the audit fee charged should be reasonable considering the audit effort, and that the audit fee may not depend on the result of the audit, the Belgian requirement implies a far more strict enforcement 
of this general rule. Regulation restricting fee setting limits the competition for (new) clients based on price.

\subsubsection{Conclusions on the regulatory regimes}

Based on the audit market regulations in place in these three areas, the Dutch audit market can be expected to be more competitive than the Belgian and the German audit markets during the period of study 1970-1994. Compared with Belgium and Germany, in the Netherlands entry requirements are less, advertising in general is allowed, there is no fixed auditor tenure, and the setting of fees is nearly without restrictions. These regulatory characteristics of the Dutch audit market are fairly close to the regulatory characteristics of audit markets in Anglo-Saxon countries. For example, current Dutch auditing standards are nearly direct copies of the IFAC standards. In addition, in terms of financial reporting the Netherlands is similar to Anglo-Saxon countries [Nobes and Parker (1998, p. 58)].

Comparing the Belgian and German audit regulation, it can be concluded that they have about equally strict regulatory regimes. Although their regulations differ at some points, these differences are less profound than the differences of either Belgium or Germany with the Netherlands. Compared with Germany, Belgium is more strict with respect to auditor tenure and audit fee setting. German audit regulation is slightly more strict with respect to entry requirements and advertising. Therefore, it can be expected that Belgian and German audit markets are about equally competitive.

The more liberal set of regulations in the Netherlands should be reflected in a number of audit market characteristics. Whether the nature of competition will be reflected in the static concentration measures is less obvious, but it should certainly be reflected in the dynamic measures of market share mobility and entry and exit [Baldwin and Gorecki (1989); Mueller (1991)]. Both seller concentration and market structure dynamics will be measured in the next sections.

\subsection{Audit firm size and data}

\subsubsection{Audit firm size}

This study uses the total number of auditors (i.e. reviseurs d'entreprises' bedrijfsrevisoren in Belgium, Wirtschaftsprüfer in Germany, and registeraccountants in the Netherlands) working in public practice for audit firms either as a partner or as an employed auditor as a measure of audit firm size. Data on the fee-income of 
audit firms would possibly provide a 'better' size measure than data on the number of auditors. For the three audit markets studied, however, audit fees have only been available for the last few years and only for a limited number of larger audit firms [see, e.g. Langendijk (1988); Meuwissen (1992); and Moriarty (1993)].

A first argument for using the number of partners and employed auditors as a firm size measure is that it is itself a direct measure of audit firm size. It is the employment of auditors that makes an audit firm a player in the audit market. In other words, fee-income can also be wiewed as merely an alternative measure of firm size, and it need not be the case that fee-income is, a priori, a better proxy of firm size than the total number of auditors.

A second argument for using number of auditors as the firm size measure is that the market for audit services is labour intensive. Therefore, a direct relationship between audit firm fee-income and the number of auditors is expected. Indeed, empirical research reports high correlations between number of auditors and feeincome. In a study on Dutch audit firms, Meuwissen (1992) reports correlations between fee-income and the number of auditors. Fee-income is measured both excluding and including non-audit fee-income. The Pearson correlation he reports for 1990 between the number of auditors and audit fee-income is 0.992 . This correlation is based on an audit firm sample of 12 large audit firms. For a much larger audit firm sample (i.e. $n=320$ ), which covers nearly the same audit firm sample as used in this study, he reports a Pearson correlation between the number of auditors and total feeincome of 0.984. A study by Zind and Zéghal (1989) of the Canadian audit industry also shows a high correlation between audit firm fee-income and number of auditors. They found a Spearman rank correlation for audit firm fee-income and the number of professional employees of 0.98. Weets and Jegers (1997) report Spearman rank correlations for the Belgian audit market for several client-based audit firm measures and the number of auditors for the years 1989 to $1994 .{ }^{10}$ Following Moizer and Turley (1987) who conclude that client sales and its square root transformation are better proxies for audit fees than the number of audits, Weets and Jegers (1997) found correlations for client sales and number of professionals varying from 0.531 to 0.653 between 1989 and 1994. For this period they reported correlations for client sales and number of professionals varying from 0.527 to 0.648 . They conclude that the number of auditors is a good proxy for measuring audit firm size. Furthermore, in this study, for the Belgian and German audit firms high correlations were found between audit firm fee-income and number of auditors for those firms for which the audit fee was known. For 18 large Belgian audit firms, the Pearson correlation

10 These client characteristics were based on the financial statements of 1300 of the largest Belgian companies. 
between the number of auditors and audit fee-income in 1990 is 0.872 . For a sample of 24 German audit firms the Pearson correlation between the number of auditors and audit fee-income in 1990 was found to be 0.919 .

A third argument for using number of auditors as a size measure is that the effects of separate consulting services on audit firm size can be excluded to a large extent. In the Dutch membership lists, auditors working in public practice are listed separately from auditors primarily involved in consulting, or any other non-public practice activities. Furthermore, in Belgium and Germany the licensing requirements do not allow auditors to provide mainly other services than auditing services.

\subsubsection{Data}

The data in this study on the number of auditors are taken from 24 membership lists that have appeared between 1970 and 1994: eight membership lists in each country. The period 1970-1994 is chosen because membership lists are available for each of the three countries since 1970. The membership lists do not cover time periods of equal length. The 24-year period is subdivided into four periods of three years, and three periods of four years and cover the years 1970, 1973, 1977, 1980, 1984, 1988, 1991 and 1994. ${ }^{11}$ All available membership lists contain a list of existing audit firms with the names of partners and the names of auditors employed for each firm. Appendix $\mathrm{B}$ gives a detailed description of the procedures used to compile the data in this study.

The general analysis of this study includes data on all audit firms active in the three national audit markets without making a distinction between large audit firms and small audit firms. There are two arguments for conducting a general analysis including both large and small audit firms. First, in Belgium, Germany and the Netherlands both large publicly listed companies and smaller private companies are legally required to have their financial statements audited. Both large and small audit firms supply services to the small auditee group, and compete for their demand. Secondly, even small audit firms have the potential of becoming a large audit firm in the time span of this study and supply services to large auditees. Hence, in the long

"For the period 1970-1994, membership lists on the Belgian auditing profession are available for every year, and for the Netherlands membership lists were published bi-annually and in some periods annually (between 1970 and 1975 , and between 1991 and 1994). However, membership lists for the German auditing profession were only published for the years 1970, 1973, 1977, 1980, $1984,1988,1991$ and 1994. For all these years, Belgian and Dutch membership lists are available, except for the year 1977 where there is no membership list for the Netherlands. Therefore, the results on the Dutch membership lists for $1975 / 76$ and 1978 were interpolated to obtain data for 1977. 
run small audit firms can compete for large auditees. Despite these arguments for an integral analysis, the market share mobility analysis is also conducted with data for only larger audit irms. Many previous audit market studies make a distinction between large and small audit firms [see, e.g. Simunic and Stein (1987)]. The main argument for this distinction is that, at least in the short run, large (listed) auditees can only be serviced by large audit firms.

\subsection{Results}

\subsubsection{Introduction}

In this section, the results of the static and dynamic analyses of audit market structure are presented. To test for significant differences between the Belgian, German and Dutch static and dynamic market structure measures, permutation tests for paired replicates are applied [Siegel and Castellan (1988, pp. 95-101)]. The results are analysed pair wise per period because, as stated earlier, the lengths of the periods covered vary. Moreover, a pair wise analysis is appropriate to control for extraneous variables affecting the three countries simultaneously (e.g. regulatory changes or economic circumstances in the period of study) which might influence the outcome of the research [Siegel and Castellan (1988, p. 74)].

Furthermore, since dynamic measures of market structure capture more of the competitive processes than concentration measures [see, e.g. Davies and Geroski (1997)], two-tailed permutation tests were conducted to test for differences on the static market structure measures, and one-tailed tests, where appropriate, were conducted to test for differences on the dynamic measures. One-tailed tests are less appropriate on the static measures since the effect of competition on seller concentration is not obvious. The differences on the measures of market share mobility and entry and exit are presented by one-tailed tests if a difference in the competitive process is to be expected (Belgium vs. the Netherlands, and Germany vs. the Netherlands) and by two-tailed tests if the difference in the competitive process remains unclear (Belgium vs. Germany).

First, in the next paragraph some descriptive results are presented. After that, in paragraph 4.6.3 the results for the seller concentration measures are given. Paragraph 4.6.4 contains the dynamic analysis and presents results for market share mobility, and audit firm entry and exit in the three audit markets. Finally, paragraph 4.6.5 provides an overview of the main results. 


\subsubsection{Descriptive results}

Since there is not much previous research about the three audit markets, TABLE $\mathbb{1}$ makes a comparison with audit markets frequently covered in earlier studies (Australia, Canada, the United Kingdom and the United States). The table provides two general indicators of audit market size: the revenue of the largest audit firm, and the total revenue of the largest six audit firms. On both indicators, the German market is larger than the Belgian and the Dutch markets. Making a comparison with the other countries, the German and Dutch audit markets appear to be larger than the Australian and Canadian audit markets. Using the same indicators, the two markets together are about as large as the UK market. The Belgian audit market is by far the smallest of the seven countries listed.

\section{TABLE 1}

Audit market size characteristics for Australia, Belgium, Canada, Germany, the Netherlands, the United Kingdom and the United States in $1994^{\mathrm{a}}$

Country

Australia

Belgium $^{b}$

Canada

Germany

Netherlands

United Kingdom

United States
Revenue of the largest audit firm
Total revenue of the six largest audit firms

"Sources: International Accounting Bulletim, 1994, Issues 143 and 146, Dublin: Lafferty Publications; International Accounting Bulletin, 1995, Issues 155, 157 and 162, Dublin: Lafferty Publications; and De Omzefciffers van 1994, 1995, Amsterdam: Het Financieele Dagblad. All figures are expressed in Million ECU, using the exchange rates of December 1994.

- The total revenue of the six largest audit firms is an approximation, according to International Accounting Bulletin, 1995, Issue 145, Dublin: Lafferty Publications. 
TABLE 2 describes the general characteristics of the three audit markets during the period of study. The first three collumns of TABLE 2 document the total size of the three markets on the basis of the headcount measure between 1970 and 1994. They show that in the three countries the total number of auditors in public practice increases in each period. Belgium has the highest growth with an average annual increase in the number of auditors of $6.0 \%$, followed by Germany with an average annual increase of $4.6 \%$. On the basis of this headcount measure for the complete markets, the German market is about twice as large as the Dutch market and about 10 times larger than the Belgian audit market. Comparing this with the audit market size characteristics of TABLE 1 , it can be observed that for the Netherlands the revenue of the largest audit firm and the total revenue of the six largest audit firms are relatively large. This difference can be explained by the fact that TABLE 1 focuses on the top-end of the market and that the Dutch market is much more concentrated (see also TABLE 3).

\section{TABLE 2}

Descriptive statistics of the Belgian, German and Dutch audit markets: 1970-1994

\begin{tabular}{|c|c|c|c|c|c|c|}
\hline \multirow{2}{*}{$\begin{array}{l}\text { Year } \\
(t)\end{array}$} & \multicolumn{3}{|c|}{$\begin{array}{c}\text { Number of auditors } \\
\text { Belgium Germany Netherlands }\end{array}$} & \multicolumn{3}{|c|}{$\begin{array}{c}\text { Number of audit firms } \\
\text { Belgium Germany Netherland }\end{array}$} \\
\hline & $\mathrm{Q}^{\mathrm{a}}$ & $Q^{a}$ & $Q^{a}$ & $N^{b}$ & $N^{b}$ & $N^{b}$ \\
\hline 1970 & 221 & 2551 & 1427 & 206 & 1758 & 306 \\
\hline 1973 & 226 & 2841 & 1649 & 196 & 1889 & 267 \\
\hline 1977 & 237 & 3308 & 1822 & 189 & 2131 & 286 \\
\hline 1980 & 256 & 3858 & 1971 & 173 & 2418 & 307 \\
\hline 1984 & 332 & 4557 & 2185 & 185 & 2837 & 373 \\
\hline 1988 & 676 & 5792 & 2523 & 318 & 3742 & 448 \\
\hline 1991 & 750 & 6627 & 2987 & 315 & 4290 & 561 \\
\hline 1994 & 894 & 7499 & 3550 & 361 & 4769 & 711 \\
\hline $\begin{array}{l}\text { Average annua } \\
\text { growth rate }\end{array}$ & $6.0 \%$ & $4.6 \%$ & $3.9 \%$ & $2.4 \%$ & $4.3 \%$ & $3.6 \%$ \\
\hline
\end{tabular}

" $Q$ is the combined size of all firms in the audit market at $t$. This includes the firms that enter the audit market between $t-1$ and $t$

b $\mathrm{N}$ is the total number of firms in the audit market at $t$. This includes firms that enter the audit market between $t-1$ and $t$. 
Columns 4, 5 and 6 of TABLE 2 give for the period between 1970 and 1994 the total number of audit firms active in the Belgian, German and Dutch audit markets. Overall, the number of audit firms is growing in the three markets indicating that the net-entry to the three markets is positive. Germany has the highest growth with an average annual increase in the number of audit firms of $4.3 \%$, followed by the Netherlands with an average annual increase of $3.6 \%$. In Belgium, the number of audit firms first decreases but thereafter increases to show over the period 1970-1994 an average annual increase in the number of audit firms of $2.4 \%$.

Combining the results on the number of auditors and the number of firms from TABLE 2, the average audit firm size can be derived. TABLE 3 presents a size profile of the audit firms in the Belgian, German and Dutch audit markets. This size profile shows that the audit firm size distribution in the three countries is highly skewed. Audit firms with only one auditor account for about $70 \%$ of the total number of audit firms in the Netherlands to almost $90 \%$ in Germany over the period 1970 $1994 .{ }^{12}$ In Belgium, the percentage of audit firms with only one auditor decreases from $97 \%$ in 1970 to $74 \%$ in 1994 suggesting that the audit market steadily develops into larger organisational forms. This is also indicated by the steady increase in the average number of auditors per firm in Belgium over the period 1970-1994. The Netherlands shows the highest average audit firm size, with five to six auditors per firm, whereas in Germany, on average only 1.5 auditors are engaged per firm.

While these results seem surprising, it is not unique to the Belgian, German and Dutch audit markets. For example, for the United States the 1993 AICPA annual report indicates that more than 30,000 members are active in firms in public practice with only one AICPA member. Moreover, the results of a 1992 report of the Australian professional organization indicate that in the period 1987-1988 more than $60 \%$ of the 6,048 audit firms employed less than five individuals (i.e. this includes nonprofessionals).

${ }^{12}$ This category of firms with one auditor consists of sole-practitioners and so-called silent firms. If auditors work for more than one audit firm, they were counted with the largest of the firms. The implication of this is that an audit firm with all auditors also working for one or more larger firms, is treated as a silen fim. In 1994 they accounted for $4.7 \%$ of the total number of German firms and for $3.5 \%$ of the total number of Dutch firms. The Belgian audit market contained no silent firms. A silent firm can be considered to be a partner of a larger audit firm. Hence, it shares its personnel with a larger audit firm and cooperates in the production of audits. However, in the market it wants to be considered to be an independent audit firm. Hence, silent firms are the result of a decision by two firms to work together in the production of audits, but both firms want to retain their "old" brand name, probably because of reputation effects and clientrelationships. 


\section{TABLE 3}

A size profile of the audit firms

in the Belgian, German and Dutch audit markets, 1970-1994

\section{Panel A: Belgium}

Number of audit firms with:

Average number

Year

(t)

$2-5$

6-10

$>10$

of auditors

auditors auditors auditors

per firm

\begin{tabular}{llllllll}
\hline 1970 & $199(97 \%)$ & $6(3 \%)$ & $1(<1 \%)$ & $0(0 \%)$ & 1.07 \\
1973 & $183(93 \%)$ & 12 & $(6 \%)$ & $0(0 \%)$ & $1(<1 \%)$ & 1.15 \\
1977 & $173(92 \%)$ & $13(7 \%)$ & $1(<1 \%)$ & $2(1 \%)$ & 1.25 \\
1980 & $152(88 \%)$ & $17(10 \%)$ & $1(<1 \%)$ & $3(2 \%)$ & 1.48 \\
1984 & $146(79 \%)$ & $34(18 \%)$ & $1(<1 \%)$ & $4(2 \%)$ & 1.80 \\
1988 & $243(76 \%)$ & $55(17 \%)$ & $12(4 \%)$ & $8(3 \%)$ & 2.13 \\
1991 & $231(73 \%)$ & $63(20 \%)$ & $11(4 \%)$ & $10(3 \%)$ & 2.38 \\
1994 & $267(74 \%)$ & $71(20 \%)$ & $16(4 \%)$ & $7(2 \%)$ & 2.48 \\
\hline
\end{tabular}

Panel B: Germany

Number of audit firms with:

Average number

Year

(t)

$2-5$

auditors
6-10 auditors
$>10$ auditors of auditors per firm

$\begin{array}{llllllll}1970 & 1572(89 \%) & 149(9 \%) & 19(1 \%) & 18(1 \%) & 1.45 \\ 1973 & 1679(89 \%) & 169(9 \%) & 19(1 \%) & 22(1 \%) & 1.50 \\ 1977 & 1864(88 \%) & 220(10 \%) & 24(1 \%) & 23(1 \%) & 1.55 \\ 1980 & 2092(87 \%) & 268(11 \%) & 35(1 \%) & 23(<1 \%) & 1.60 \\ 1984 & 2442(86 \%) & 328(12 \%) & 40(1 \%) & 27(<1 \%) & 1.61 \\ 1988 & 3254(87 \%) & 423(11 \%) & 34(<1 \%) & 31(<1 \%) & 1.55 \\ 1991 & 3751(87 \%) & 463(11 \%) & 45(1 \%) & 31(<1 \%) & 1.55 \\ 1994 & 4169(87 \%) & 520(11 \%) & 47(<1 \%) & 33(<1 \%) & 1.57\end{array}$




\section{TABLE 3 (Continued)}

\section{Panel C: the Netherlands}

Number of audit firms with:

Average number

Year

(t) auditor $2-5$ auditors
$6-10$ auditors
$>10$ auditors of auditors per firm

$\begin{array}{rrrrrrrr}1970 & 208(68 \%) & 73(24 \%) & 7(2 \%) & 18(6 \%) & 4.66 \\ 1973 & 182(68 \%) & 61(23 \%) & 10(4 \%) & 14(5 \%) & 6.18 \\ 1977 & 197(69 \%) & 69(24 \%) & 6(2 \%) & 14(5 \%) & 6.37 \\ 1980 & 224(73 \%) & 59(19 \%) & 7(2 \%) & 17(6 \%) & 6.42 \\ 1984 & 270(72 \%) & 78(21 \%) & 7(2 \%) & 18(5 \%) & 5.86 \\ 1988 & 333(74 \%) & 86(19 \%) & 9(2 \%) & 20(5 \%) & 5.63 \\ 1991 & 399(71 \%) & 126(23 \%) & 17(3 \%) & 19(3 \%) & 5.32 \\ 1994 & 513(72 \%) & 157(22 \%) & 22(3 \%) & 22(3 \%) & 4.99\end{array}$

a This category also contains silent firms. The percentage of silent firms ranges from $2 \%$ in 1970 to about $5 \%$ in 1994 .

"This category also contains silent firms. The percentage of silent firms ranges from $3 \%$ in 1970 to about $4 \%$ in 1994.

\subsubsection{Results for the static market structure measures}

TABLE 4 presents results for traditional static market structure measures. Two common measures are used: the concentration ratio $\mathrm{C}_{4}$ and the Hirschman-Herfindahl index (H-index). The results for the four-firm concentration ratio show that (at the 0.05 level) the Dutch audit market is significantly more concentrated than the Belgian $(p=0.008)$ and German $(p=0.008)$ audit markets. For example, in 1994 the top-four Dutch audit firms hold $52 \%$ of the market while the top-four Belgian and German audit firms only hold $28 \%$ respectively $16 \%$ of the market. The table also shows a general increase in the four-firm concentration ratio in all three countries between 1970 and 1994.

Furthermore, the results for the complete industry firm-size distribution ( $\mathrm{H}$ Index) indicate that (at the 0.05 level) the Dutch audit market is significantly more concentrated than the Belgian $(p=0.008)$ and German $(p=0.008)$ audit markets. 


\section{TABLE 4}

Static Market Structure Measures

for the Belgian, German and Dutch audit markets, 1970-1994:

the four firm concentration ratio $\mathrm{C}_{4}$ and the Hirschman-Herfindahl index.

Year

$$
\begin{gathered}
\text { Belgium } \\
\mathrm{C}_{4}^{\mathrm{a}, \mathrm{b}} \stackrel{\mathrm{H} \text {-index }}{\mathrm{cod}}
\end{gathered}
$$

Germany

Netherlands

$\mathrm{C}_{4}^{\mathrm{a}, \mathrm{b}} \mathrm{H}$-index ${ }^{c_{n} d}$

$\mathrm{C}_{4}^{\mathrm{a}, \mathrm{b}} \quad \mathrm{H}$-index ${ }^{\mathrm{c}, \mathrm{d}}$

$\begin{array}{lllllll}1970 & 0.07 & 0.006 & 0.09 & 0.004 & 0.37 & 0.047 \\ 1973 & 0.10 & 0.009 & 0.10 & 0.005 & 0.52 & 0.079 \\ 1977 & 0.16 & 0.012 & 0.11 & 0.005 & 0.51 & 0.079 \\ 1980 & 0.23 & 0.022 & 0.12 & 0.005 & 0.51 & 0.079 \\ 1984 & 0.27 & 0.026 & 0.11 & 0.005 & 0.52 & 0.080 \\ 1988 & 0.21 & 0.020 & 0.12 & 0.006 & 0.48 & 0.071 \\ 1991 & 0.24 & 0.023 & 0.15 & 0.008 & 0.56 & 0.088 \\ 1994 & 0.28 & 0.025 & 0.16 & 0.009 & 0.52 & 0.075\end{array}$

a The four firm concentration ratio in an $\mathrm{N}$ firm audit market at a given moment in time with the $\mathrm{N}$ firm ranked in order of decreasing size, is defined as, $C_{4}=\Sigma s h_{i}(4, i=1)$, where sh; is the market share of firm $\mathrm{i}$. That is, $\mathrm{C}_{4}$ is the cumulative market share of the four largest of the $\mathrm{N}$ firms in the audit market.

b Two-tailed $p$ for a permutation test (paired replicates) for the difference in the four firm concentration ratio $C_{4}$ between the Belgium and Germany in the eight years is 0.023 . Twotailed $p$ for a permutation test (paired replicates) for the difference in the four firm concentration ratio $\mathrm{C}_{4}$ between Belgium and the Netherlands in the eight years is 0.008 . Twotailed $p$ for a permutation test (paired replicates) for the difference in the four firm concentration ratio $\mathrm{C}_{4}$ between Germany and the Netherlands in the eight years is 0.008 .

- The Hirschunan-Herfindahl index for an $\mathrm{N}$-firm audit market is defined as $\mathrm{H}=\Sigma \operatorname{sh}_{i}^{2}(\mathrm{~N}, \mathrm{i}=1)$. That is, $\mathrm{H}$ is the sum of the squared market shares of all the firms in the audit market at a given moment in time.

d Two-tailed $p$ for a permutation test (paired replicates) for the difference in the HirschmanHerfindahl index between the Belgium and Germany in the eight years is 0.008 . Two-tailed $p$ for a permutation test (paired replicates) for the difference in the Hirschman-Herfindahl index between Belgium and the Netherlands in the eight years is 0.008 . Two-tailed $p$ for a permutation test (paired replicates) for the difference in the Hirschman-Herfindahl index between Germany and the Netherlands in the eight years is 0.008 .

According to the exponential nature of the Hirschman-Herfindahl index permutation tests, requiring interval scaled data, might not be appropriate. To test for the robustness of the permutation tests, also Wilcoxon signed ranks tests, which are suited for ordinal data, were conducted. However, similar results were found with the Wilcoxon signed ranks test (All three tests: $\mathrm{T}^{*}=36$ with $\mathrm{N}=8, p=0.008$ ). 
Another finding is that seller concentration levels based on a headcount measure including all audit firms are considerably lower than seller concentration levels based on client-size audit firm size measures. This can be seen by looking at previous studies presenting H-index measurements for Belgium, Germany and the Netherlands. Weets and Jegers (1997) calculate the H-Index for the Belgian audit market from 1989 to 1995 based on the number of auditors as well as on several client-size measures. Their results show a relatively low H-Index based on the number of professionals ranging from 0.017 in 1989 to 0.025 in 1993 (and these results are comparable to the results on the $\mathrm{H}$-Index found in this study). The results on the client-size measures show higher values for the H-Index ranging from 0.059 in 1989 to 0.094 in 1995 for the firm size measure based upon client sales. The results for the study by Marten (1996) for the $\mathrm{H}$-index for the German market are ranging from 0.141 to 0.220 in the period 1990 to 1994 . In a study by Quick (1998) the $\mathrm{H}$-index for the German market ranges from 0.223 to 0.238 in the period 1991 to 1994. The results for the study by Langendijk and Deetman (1990) on the Dutch market are 0.336 for 1979 and 0.345 for 1988 . All three studies used an audit firm size measure based on the sales of larger clients. The size of the audit firm is in their approach the sum of the sales of the audit firm clients. This automatically entails the use of a subset of audit firms and a truncated client sample. ${ }^{13}$

In sum, the static results first indicate that concentration measures using headcount data and based on complete audit markets are much lower than those based on client data for a subset of larger audit firms. The results further indicate that over time in all three markets there is a general increase in concentration levels. The crosscountry comparison shows that the Dutch audit market has the highest concentration.

\subsubsection{Results for the dymamic market structure measures}

This paragraph will first present the results for the market share mobility measure and then the results for the entry and exit rates. The first three columns of TABLE 5 summarize the results for the market share mobility measure for all continuing firms. The results for the three countries indicate that (at the 0.10 level) the Netherlands has a significantly higher average market share mobility compared with Belgium $(p=$ $0.063)$ and Germany $(p=0.008)$. In the Netherlands, on average per period $8.8 \%$ of the market is transferred among all continuing firms, whereas in Belgium and

${ }_{13}$ The effect of the use by Langendijk and Deetman (1990) of a client-sales based firm size measure can be separated from the effect of using a truncated audit firm sample. When the $C_{4}$ and $H$-index are calculated with number of auditors as the audit firm size measure for Langendijk and Deetman"s audit firm sample the results are 0.132 for 1979 and 0.171 for 1988 . 
Germany this is only $6.7 \%$ respectively $6.5 \%$. The permutation tests for paired replicates does not indicate that the difference in market share mobility between Belgium and Germany is statistically significant at conventional levels $(p=0.703)$. Furthermore, in all three countries a general increase in market share mobility over time can be observed.

\section{TABLE 5}

Market share mobility (MOB)

for continuing firms and for the largest eight continuing firms in the Belgian, German and Dutch audit markets, 1970-1994

\begin{tabular}{|c|c|c|c|c|c|c|}
\hline \multirow{3}{*}{$\begin{array}{l}\text { Period } \\
(\mathrm{t}-1, \mathrm{t})\end{array}$} & \multicolumn{3}{|c|}{ Continuing firms } & \multicolumn{3}{|c|}{ Largest eight continuing firms } \\
\hline & Belgium & Germany & Netherlands & Belgium & Germany & Jetherlands \\
\hline & $\mathrm{MOB}^{\mathrm{a}, \mathrm{b}}$ & $\operatorname{MOB}^{\mathrm{a}, \mathrm{b}}$ & $\mathrm{MOB}^{\mathrm{a}, \mathrm{b}}$ & $\mathrm{MOB}^{\mathrm{a}, \mathrm{c}}$ & $\mathrm{MOB}^{\mathrm{a}_{\mathrm{a}} \mathrm{c}}$ & $\operatorname{MOB}^{\mathrm{a}, c}$ \\
\hline $1970-1973$ & 0.036 & 0.051 & 0.136 & 0.017 & 0.035 & 0.109 \\
\hline $1973-1977$ & 0.042 & 0.053 & 0.068 & 0.028 & 0.029 & 0.037 \\
\hline $1977-1980$ & 0.053 & 0.058 & 0.061 & 0.033 & 0.034 & 0.024 \\
\hline $1980-1984$ & 0.070 & 0.056 & 0.063 & 0.037 & 0.031 & 0.042 \\
\hline $1984-1988$ & 0.103 & 0.078 & 0.087 & 0.044 & 0.038 & 0.045 \\
\hline $1988-1991$ & 0.082 & 0.076 & 0.108 & 0.036 & 0.055 & 0.073 \\
\hline $1991-1994$ & 0.086 & 0.084 & 0.094 & 0.042 & 0.049 & 0.062 \\
\hline Average & 0.067 & 0.065 & 0.088 & 0.034 & 0.039 & 0.056 \\
\hline
\end{tabular}

" MOB is defined as $\Sigma\left|s h_{n}-s h_{i 0}\right| / 2(\mathrm{~N}, i=1)$, where $s h_{i 0}$ is the market share of an audit firm $i$ at time 0 and $\mathrm{sh}_{\mathrm{in}}$ is the market share of the same firm at time $t$. The total number of firms in the market is $\mathrm{N}$.

- Two-tailed $p$ for a permutation test (paired replicates) for the difference in market share mobility between the Belgium and Germany in the seven periods is 0.703 . One-tailed $p$ for a permutation test (paired replicates) for the difference in market share mobility between Belgium and the Netherlands in the seven periods is 0.063 . One-tailed $p$ for a permutation test (paired replicates) for the difference in market share mobility between the Germany and the Netherlands in the seven periods is 0.008 .

- Two-tailed $p$ for a permutation test (paired replicates) for the difference in market share mobility between the Belgium and Germany in the seven periods is 0.266 . One-tailed $p$ for a permutation test (paired replicates) for the difference in market share mobility between Belgium and the Netherlands in the seven periods is 0.039 . One-tailed $p$ for a permutation test (paired replicates) for the difference in market share mobility between the Germany and the Netherlands in the seven periods is 0.031 . 
Columns 4, 5 and 6 of TABLE 5 report the market share mobility for a subset of the audit market: the largest eight continuing audit firms. ${ }^{14}$ Again, in the Netherlands the market share mobility in the top-end of the audit market is (at the 0.05 level) significantly higher than in the other two countries. Furthermore, the results do not provide evidence that the market share mobility in Belgium and Germany differs for the large firms ( $p=0.266$ ). Finally, as was already observed for the complete market, also for the largest firms, in general over time, market share mobility is increasing.

The results for entry and exit are presented in TABLES 6 and 7. First, the results with respect to entry of audit firms are considered. TABLE 6 gives the results for total entry in terms of number of audit firms (TER), and shows the origin of entering firms by indicating whether the founders are from existing audit firms (AER) or founders new to the audit sector (LER). On average, $7.0 \%$ (Belgium), 6.7\% (Germany) and $8.6 \%$ (the Netherlands) of the audit firms are entrants. The total entry rate for the Netherlands is (at the 0.05 level) significantly higher than the German total entry rate $(p=0.023)$. However, the permutation test for paired replicates does not indicate that the difference in total entry rate between the Netherlands and Belgium is statistically significant at the 0.05 level $(p=0.117)$. A closer look at these two total entry rates shows that in every period the total entry to the profession is higher in the Netherlands, except for the period 1984-1988 when the Belgian audit market almost doubles. Apparently, the introduction of the Fourth EC Directive in 1985, requiring medium-sized companies to have an audit, had a substantial impact on the Belgian audit market. Especially the new firm entry is in this period exceptionally high. The Dutch audit market shows no increase in both the total entry rate and the new firm entry rate after the introduction of the Fourth EC Directive, probably indicating that most medium-sized companies already had voluntary audits.

The annual averages of the entry rates specifying the mode of entry indicate that in general audit furms established by founders new to the audit sector form the largest category of entry. That is, the annual average for LER is the highest in all three countries. While both AER and LER are on average high for the Netherlands, only AER is significantly higher at conventional levels. Using a 0.05 significance level, no significant differences were observed between the Belgian, German and Dutch audit markets for LER. As stated earlier, regulatory changes stimulating the demand for audit services will have a substantial effect on the new firm entry rate. Consider, for instance, the Belgian audit market. The existing firm entry rate shows

14 Taking the eighth audit firm as the cut-off point for the subset of larger audit firms is somewhat arbitrary. Therefore, the analysis was repeated for the largest ten audit firms which yielded similar results as reported in TABLE 5. 
a steady increase, whereas the new firm entry rate shows quite a lot of variation. Probably because of the introduction of the Fourth EC Directive in 1985, new firm entry shows a highest rate of $43.7 \%$ in the period 1984-1988. It then decreases sharply, which apparently indicates that the audit market stabilizes. A similar pattern of growth and decline can be observed in Germany. After the introduction of the Fourth EC Directive in 1985 , the audit market exhibits a peak level of $23.7 \%$ new firm entry in the period 1984-1988, followed by a steep decline in 1988-1991.

Finally, the changes in total entry rates over time are quite different for the three countries. In the Netherlands, the total entry rate shows a gradual increase during the period of study. The total entry rates for the Belgian and German audit professions do not exhibit a clear pattern over time, mainly because of the high TER in the period 1984-1988, and the low TER in the period thereafter. This can be explained by the gradual increase in AER, combined with the probable effect of the Fourth EC Directive on LER, resulting in an unstable pattern of TER in both countries. Controlling for this effect, at least the Belgian audit market shows an overall increase in TER.

The results for the exit of audit firms are presented in TABLE 7. This table shows the results for total exit in terms of number of audit firms (TXR), and shows the nature of the exit by indicating whether the exiting firm was taken over by another firm (merger exit or MXR) or whether the auditors of the exiting firm retired or exited the auditing area (pure exit or PXR). The average annual total exit rate is $5.4 \%$ in Belgium, 3.3\% in Germany, and 6.1\% in the Netherlands. As compared to the Belgian and German audit markets, the total exit rate is (at the 0.05 level) significantly higher for the Dutch audit market $(p=0.039$, respectively $p=0.008$ ). The results furthermore show that the total exit rate for the Belgian audit market is (at the 0.05 level) significantly higher than the total exit rate for the German audit market $(p=0.016)$.

Looking at the mode of exit it appears that in Belgium and Germany PXR is the most important exit category. In the Netherlands, MXR is the most important exit category indicating a high level of merger activities. As mentioned earlier, MXR is to be considered a superior indicator of competition in the market than PXR since the age distribution of auditors in smaller audit firms will have a substantial impact on PXR as the effects of retirement are included in this measure. Using a 0.05 significance level, the Dutch audit market shows a significantly higher MXR than the Belgian and German audit markets ( $p=0.008$ for both analyses). Furthermore, the Belgian audit market exhibits (at the 0.10 level) a significantly higher MXR than the German audit market $(p=0.078$ ). Finally, the results show that Belgium has the highest PXR, followed by the Netherlands. 


\section{TABLE 6}

Entry rate of audit firms (in number of firms) split into existing firm entry and new firm entry in the Belgian, German and Dutch audit markets, 1970-1994

\begin{tabular}{|c|c|c|c|c|c|c|c|c|c|}
\hline \multirow{3}{*}{$\begin{array}{l}\text { period } \\
(t-1, t)\end{array}$} & \multicolumn{3}{|c|}{ Belgium } & \multicolumn{3}{|c|}{ Germany } & \multicolumn{3}{|c|}{ Netherlands } \\
\hline & $\begin{array}{l}\text { Total } \\
\text { entry }\end{array}$ & $\begin{array}{c}\text { Existing } \\
\text { firm } \\
\text { entry }\end{array}$ & $\begin{array}{l}\text { New } \\
\text { firm } \\
\text { entry }\end{array}$ & $\begin{array}{l}\text { Total } \\
\text { entry }\end{array}$ & $\begin{array}{c}\text { Existing } \\
\text { firm } \\
\text { entry }\end{array}$ & $\begin{array}{l}\text { New } \\
\text { firm } \\
\text { entry }\end{array}$ & $\begin{array}{l}\text { Total } \\
\text { entry }\end{array}$ & $\begin{array}{l}\text { Existing } \\
\text { firm } \\
\text { entry }\end{array}$ & $\begin{array}{l}\text { New } \\
\text { firm } \\
\text { entry }\end{array}$ \\
\hline & $\mathrm{TER}^{\mathrm{a} \text {, ti }}$ & $A E R^{c, d}$ & $\operatorname{LER}^{e, f}$ & TER $^{\mathrm{a}, \mathrm{b}}$ & $A E R^{\circ d}$ & $\mathrm{LER}^{\mathrm{e}, \mathrm{f}}$ & $\operatorname{TER}^{a, b}$ & $\mathrm{AER}^{\mathrm{c}, \mathrm{d}}$ & $\mathrm{LER}^{\mathrm{ef}}$ \\
\hline $970-1973$ & $11.2 \%$ & $0.0 \%$ & $11.2 \%$ & $17.1 \%$ & $6.9 \%$ & $10.2 \%$ & $14.2 \%$ & $6.0 \%$ & $8.2 \%$ \\
\hline $1973-1977$ & $18.5 \%$ & $1.6 \%$ & $16.9 \%$ & $21.6 \%$ & $7.1 \%$ & $14.5 \%$ & $26.2 \%$ & $12.2 \%$ & $14.0 \%$ \\
\hline $1977-1980$ & $12.1 \%$ & $2.3 \%$ & $9.8 \%$ & $22.5 \%$ & $7.9 \%$ & $14.6 \%$ & $25.1 \%$ & $13.0 \%$ & $12.1 \%$ \\
\hline $1980-1984$ & $27.0 \%$ & $5.4 \%$ & $21.6 \%$ & $25.4 \%$ & $9.1 \%$ & $16.3 \%$ & $34.3 \%$ & $14.3 \%$ & $20.0 \%$ \\
\hline $1984-1988$ & $53.8 \%$ & $10.1 \%$ & $43.7 \%$ & $32.0 \%$ & $8.3 \%$ & $23.7 \%$ & $35.0 \%$ & $18.2 \%$ & $16.8 \%$ \\
\hline $1988-1991$ & $17.8 \%$ & $11.4 \%$ & $6.4 \%$ & $20.3 \%$ & $7.2 \%$ & $13.1 \%$ & $36.9 \%$ & $15.1 \%$ & $21.8 \%$ \\
\hline $1991-1994$ & $25.7 \%$ & $14.1 \%$ & $11.6 \%$ & $21.1 \%$ & $9.4 \%$ & $11.7 \%$ & $35.3 \%$ & $1.5 .7 \%$ & $19.6 \%$ \\
\hline Annual average & $7.0 \%$ & $1.9 \%$ & $5.1 \%$ & $6.7 \%$ & $2.3 \%$ & $4.4 \%$ & $8.6 \%$ & $3.9 \%$ & $4.7 \%$ \\
\hline
\end{tabular}

a TER is the total entry rate in number of firms and defined as $N E(t) / N(t)$, where $N E(t)$ is the number of firms that enter the audit market between time $t-1$ and $t$, and $N(t)$ is the total number of firms in the audit market at $t$.

- Two-tailed $p$ for a permutation test (paired replicates) for the difference in the total entry rate in number of firms between the Belgium and Germany in the seven periods is 0.875 . One-tailed $p$ for a permutation test (paired replicates) for the difference in the total entry rate in number of firms between Belgium and the Netherlands in the seven periods is 0.117 . One-talled $p$ for a permutation test (paired replicates) for the difference in the total entry rate in number of firms between Germany and the Netherlands in the seven periods is 0.023 .

- AER is the entry rate in terms of the number of audit firms established by auditors leaving existing audit firms.

Two-tailed $p$ for a permutation test (paired replicates) for the difference in the existing firm entry rate in number of firms between Belgium and Germany in the seven periods is 0.422 . One-tailed $p$ for a permutation test (paired replicates) for the difference in the existing firm entry rate in number of firms between Belgium and the Netherlands in the seven periods is 0.008 . One-tailed $p$ for a permutation test (paired replicates) for the difference in the existing firm entry rate in number of firms between Germany and the Netherlands in the seven periods is 0.016 .

LER is the entry rate in terms of the number of audit firms established by auditors who just received their audit license.

Two-tailed $p$ for a permutation test (paired replicates) for the difference in the new firm entry rate in number of firms between Belgium and Germany in the seven periods is 0.594 . One-tailed $p$ for a permutation test (paired replicates) for the difference in the new firm entry rate in number of firms between Belgium and the Netherlands in the seven periods is 0.398 . One-tailed $p$ for a permutation test (paired replicates) for the difference in the new firm entry rate in number of firms between Germany and the Netherlands in the seven periods is 0.305 . 
Over time, there is no clear pattern in the level of total exit rates in the three countries. However, in Belgium and Germany MXR is increasing over time, whereas in all three countries a decrease of PXR can be observed. This explains the unclear patterns of TXR over the period under study.

Comparing the results for entry and exit, it appears that Belgium has the highest rates on both new firm entry and pure exit, resulting in net entry, however. A possible explanation is that the Belgian audit market is a relatively young and growing market. ${ }^{15}$ In 1970, at the start of the period under study, the Belgian audit market was small and consisted almost entirely of sole-practitioners (see TABLE 3). Also, at that time, Belgian auditors were only granted few statutory assignments. For example, not earlier than in 1975 they were granted the monopoly to audit banks and insurance companies. In 1985, due to the Fourth EC Directive, they were granted the right to audit medium sized companies. The relatively high new entry rate in the period 1984-1988 indicates that the demand for audit services rapidly increased because of this regulatory change. In, for example, the Netherlands, the Fourth EC Directive had a smaller impact on the demand of audit services, probably because many medium sized companies had their annual accounts already voluntarily audited. Owing to such regulatory changes the demand for audit services increased and the Belgian audit market came to a relatively quick development, explaining the high new firm entry and pure exit and the relative large market growth in the period under study. Similar results were found for other smaller audit markets [Lee (1994)].

\subsubsection{Overview of the results}

In sum, the results of this section indicate that of the three markets the Dutch audit market shows the highest static concentration, but that at the same time the dynamic measures of market structure are also significantly higher in the Netherlands. The higher Dutch market share mobility also holds for a sub sample of large audit firms. Furthermore, although the Belgian compared with the German audit market exhibits higher seller concentration, the dynamic measures of market structure show no systematic significant differences between the two markets. Therefore, no significant differences could be observed between the Belgian and German audit market structures.

13 According to organizational ecology, markets evolve over time to maturity following a common pattern of slow initial growth, subsequent rapid growth, and stabilization [see, e.g. Hamnan and Carroll (1992); Hannan (1997)]. The high new firm entry rates of the Belgian audit profession typically indicate a young and developing market. 


\section{TABLE 7}

Exit rate of audit firms (in number of firms) split into merger exit and pure exit in the Belgian, German and Dutch audit markets, 1970-1994

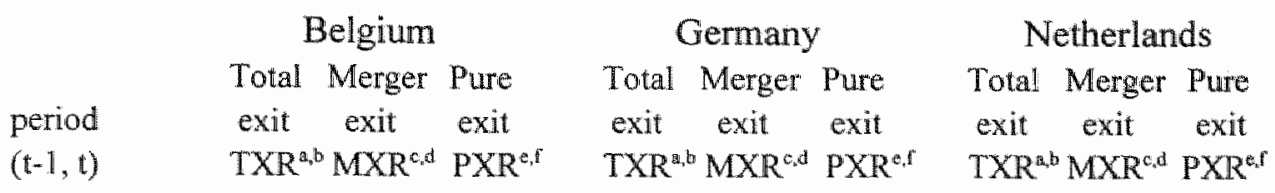

\begin{tabular}{|c|c|c|c|c|c|c|c|c|c|}
\hline $70-1973$ & $15.5 \%$ & $1.4 \%$ & $14.1 \%$ & $10.9 \%$ & $3.9 \%$ & $7.0 \%$ & $25.2 \%$ & $13.7 \%$ & $11.5 \%$ \\
\hline $1973-1977$ & $21.4 \%$ & $3.6 \%$ & $17.8 \%$ & $11.5 \%$ & $2.8 \%$ & $8.7 \%$ & $21.0 \%$ & $9.7 \%$ & $11.3 \%$ \\
\hline $1977-1980$ & $19.0 \%$ & $6.3 \%$ & $12.7 \%$ & $12.1 \%$ & $3.4 \%$ & $8.7 \%$ & $19.6 \%$ & $9.8 \%$ & $9.8 \%$ \\
\hline $1980-1984$ & $21.2 \%$ & $6.9 \%$ & $14.3 \%$ & $12.5 \%$ & $4.1 \%$ & $8.4 \%$ & $20.2 \%$ & $9.9 \%$ & $10.3 \%$ \\
\hline $84-1988$ & $20.5 \%$ & $8.1 \%$ & $12.4 \%$ & $10.4 \%$ & $3.4 \%$ & $7.0 \%$ & $22.0 \%$ & $11.2 \%$ & $10.8 \%$ \\
\hline 1988-1991 & $18.3 \%$ & $8.8 \%$ & $9.5 \%$ & $8.7 \%$ & $4.4 \%$ & $4.3 \%$ & $21.0 \%$ & $12.5 \%$ & $8.5 \%$ \\
\hline 91-1994 & $14.9 \%$ & $7.0 \%$ & $7.9 \%$ & $12.3 \%$ & $6.5 \%$ & $5.8 \%$ & $18.0 \%$ & $12.5 \%$ & $5.5 \%$ \\
\hline & $4 \%$ & $7 \%$ & $3.7 \%$ & $3.3 \%$ & $1.2 \%$ & $2.1 \%$ & $6.1 \%$ & $3.3 \%$ & 18 \\
\hline
\end{tabular}

a. TXR is the total exit rate in number of audit firms defined as $N X(t) / N(t-1)$, where $N X(t)$ is the total number of firms that exit the audit market between $t-1$ and $t$, and $N(t-1)$ is the total number of firms in the audit market at $t-1$.

b Two-tailed $p$ for a permutation test (paired replicates) for the difference in the total exit rate in number of firms between Belgium and Germany in the seven periods is 0.01 .6 . One-tailed $p$ for a permutation test (paired replicates) for the difference in the total exit rate in number of firms between Belgium and the Netherlands in the seven periods is 0.039 . One permutation test (paired replicates) for the difference in the total exit rate in mumber of firms between Germany and the Netherlands in the seven periods is 0.008 .

MXR is the merger exit rate in terms of number af audit firms.

¿ Two-tailed $p$ for a permutation test (paired replicates) for the difference in the merger exit rate in number of firms between Belgium and Germany in the seven periods is 0.078 . One-tailed $p$ for a permutation test (paired replicates) for the difference in the nerger exit rate in number of firms between Belgium and the Netherlands in the seven periods is 0.008 . One-tailed $p$ for a permutation test (paired replicates) for the difference in the merger exit rate in number of firms between Germany and the Netherlands in the seven periods is 0.008 .

- PXR is the 'pure' exit rate in terms of number of audit firms.

f Two-tailed $p$ for a permutation test (paired replicates) for the difference in the pure exit rate in number of firms between Belgium and Germany in the seven periods is 0.016 . One-tailed $p$ for a permutation test (paired replicates) for the difference in the pure exit rate in number of firms between Belgium and the Netherlands in the seven periods is 0.008 . One-tailed $p$ for a permutation test (paired replicates) for the difference in the pure exit rate in number of firms between Germany and the Netherlands in the seven periods is 0.016 . 
The results further indicate that concentration measures based on complete audit markets are much lower than those based on client data for a subset of larger audit firms. Regarding the patterns over time, the results indicate that there is overall an increase in concentration levels, and in market share mobility in all three countries. Finally, over time there is an increase in entry rates in Belgium and the Netherlands, but there is no clear pattern in the entry rates in Germany, and in the exit rates in the three countries.

\subsection{Summary and conclusions}

The main purpose of this study was to document both the static and dynamic characteristics of three audit markets, which vary in terms of their regulatory regimes, and to assess what information that provides about competition in these markets. It does so using data on the complete Belgian, German and Dutch audit markets for the period between 1970 and 1994. These data were taken from the membership lists of the professional bodies of statutory auditors in the three countries. The main results of the study indicate that: (1) the Dutch audit market is more concentrated than the Belgian and German audit markets, but the Netherlands also has a higher market share mobility, and a higher audit firm entry and exit; (2) of the three markets the Dutch market is the most liberal in terms of audit regulation, and has the highest scores on the dynamic measures of audit market structure; and (3) the results for market share mobility also hold for a restricted sample of larger audit firms.

The results shown in this study about what goes on beneath the seller

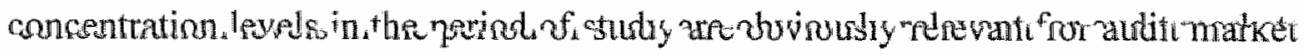
policy making. The increasing and high static seller concentration levels documented in this study, which are in general also found in previous studies, clearly fail to reveal the dynamics of market share transfers, and entry and exit. In this study high static measures of market structure go hand in hand with high dynamic measures of market structure suggesting that high levels of concentration do not indicate limited competition. This finding also suggests that the views expressed by the profession of increasing ("unhealthy") competition can be consistent with increasing concentration.

A few caveats are in order. First, economic theory is as yet not very precise about the link between observed market share mobility, entry and exit, and the degree of rivalry in a market. The interpretation of the results in this study is based on the general notion that market instability reflects stiff competition. Second, it is still possible that an audit fee-income measure is superior to the headcount measure used in this study. On the other hand, data sources such as used in this study are available 
in more countries. While the data gathering costs are substantial, these data sources create interesting opportunities for further comparative audit market research. 


\section{Appendix A}

\section{An analysis of the regulatory regimes of the auditing professions in Belgium, Germany and the Netherlands ${ }^{16}$}

\section{A.1 Introduction}

This appendix provides an overview of the regulations of the auditing professions in Belgium, Germany and the Netherlands in the period under study 1970-1994. ${ }^{17}$ The next section describes the auditing laws and regulations in Belgium. Section A.3 looks at the German regulatory framework, which will be followed in section A.4 with a description of the laws and regulations of the Dutch audit market. Each of the three sections on national auditing laws and regulations contains the following subjects: an overview of the auditing profession, the admission to the profession, the appointment procedure, auditor independence and auditor liability. Section A.5 discusses the potential effects of the regulatory regimes on the three audit markets covered in this appendix.

\section{A.2 Audit market regulation in Belgium}

\section{A.2.1 Overview of the Belgian auditing profession}

The Belgian accounting and auditing profession is organized in two main bodies: the Institut des Reviseurs d'Entreprises/Instituut der Bedrijfsrevisoren (Institute of Auditors) and the Institut des Experts Comptables/Instituut der Accountants (Institute of Chartered Accountants). According to the Act of 21 February 1985, only members of the Institute of Auditors, called reviseurs d'entreprises/bedrijfsrevisoren, are eligible to conduct statutory audits. Members of the Institute of Chartered Accountants are not authorized to carry out statutory audits. However, they were given a joint monopoly, shared with reviseurs d'entreprises/bedrijfsrevisoren, with respect to contractual audits and other inspection services regarding financial matters.

to This appendix is based on Meuwissen and Maijoor (1997).

"A brief description of these three regulatory regimes has already been given in section 4.4. 
The 1985 Act encompassed a legislative reform of the auditing profession. The two main forces behind this 1985 reform were the implementation of the Fourth EEC Directive, requiring public and private limited liability companies of a certain size to have their annual accounts audited, and a political agreement on the auditor's obligation to provide Workers' Councils with the same information as shareholders. In addition, Workers' Councils obtained the right to veto the appointment of an auditor. Other aims of the legislative reform were to provide auditors with more flexibility in matters of establishment of partnerships and in matters of incompatible activities, and to give chartered accountants their own separate professional organization.

Reviseurs d'entreprises/bedrijfsrevisoren are required to be members of the Institut des Reviseurs d'Entreprises/Instituut der Bedrijfsrevisoren, the professional body which also acts as the regulatory body of the Belgian auditing profession. The auditing profession is under the supervision of the Ministry of Economic Affairs and is assisted in this respect by the High Council for Audit and Accountancy. The main function of a reviseur d"entreprises/bedrijfsrevisor is to carry out assignments that are reserved by law for members of the profession, primarily the conduct of statutory audits. In addition, they may perform compatible assignments, such as other inspection tasks (reviewing annual accounts of companies) and may provide consultancy services in accountancy. Nevertheless, these compatible assignments may not form the core services supplied by the auditors. A particularity of the Belgian regulations is that auditors are required to have a special license from the prudential control authorities to be eligible to perform statutory audits of entities under prudential control, like banks, insurance companies and listed companies.

Statutory audit requirements have gradually been introduced in Belgium during the period of study. ${ }^{18}$ In 1970 , at the start of the period, only banks, investment companies and public authorities were required to have a statutory audit. In 1975, insurance companies became subject to an audit requirement, and the companies Act in 1976 introduced the audit of large and medium-sized public limited liability companies. After the introduction of the Fourth EEC Directive in 1985, also large and medium-sized private limited liability companies and incorporated partnerships were required to have their annual accounts audited.

is Only those entities are listed which are subject to an audit as a requirement of the Fourth, Seventh, Bank Accounts and Insurance Accounts EU Directives, or which form a substantial part of the audit engagements of audit firms. 


\section{A.2.2 Audit market regulation ${ }^{19}$}

\section{Admission to the profession}

In Belgium, the entry to the profession is regulated by the Royal Decree of 13 October 1987. The application of this Royal Decree is entrusted to the Board of the Institute of Auditors. This Board delegated the supervision of the education of the Belgian auditing profession to the Training Committee, composed exclusively of members of the Board of the Institute of Auditors.

In Belgium, the training for the profession is organized by means of a threeyear practical course. In order to be admitted to this traineeship the candidate should fulfil the following conditions: (1) a candidate should be of Belgian nationality or reside in Belgium; (2) a candidate must not have been deprived of political and civil rights, not be in bankruptcy, and not have been condemned of specific types of offence defined by law; (3) a candidate must have a university degree, or an equivalent foreign university degree, or candidates must have a degree of a higher school of vocational training plus five years of practical training or two years of experience as a chartered accountant; (4) a candidate needs to pass the entrance examination; and (5) a candidate must have drawn up an agreement for a traineeship with a supervisor, who has to be an auditor for at least five years. ${ }^{20}$

The entrance examination is organized by the Training Committee and covers a wide range of subjects. ${ }^{21}$ Candidates with a university education can obtain exemptions for some or all subjects of the entrance examination when they already passed the subjects during their university education. Presently, Belgian universities adapt some of their courses to the entrance examination requirements of the Belgian Institute of Auditors to provide candidates with the opportunity to obtain exemptions for the entrance examination. These university courses must be approved by the Training Committee.

During the traineeship candidates are guided by their supervisor, and the Training Committee will supervise the progress of the trainees. During the traineeship, candidates are required to gain at least three years of practical experience

19 This paragraph only addresses the regulation of reviseurs d'entreprises/bedrijfsrevisoren since they are the only individuals eligible to conduct statutory audits.

${ }^{20}$ The Institute of Auditors formulated several other requirements with respect to the traineeship. For example, a candidate is required to spend at least 1,000 hours per year on auditing.

"These subjects are: Bookkeeping. Financial Accounting and Financial Statement Analysis, Management Accounting, Company Law, Tax Law, Civil Law, Commercial Law, Labour Law and Social Security Law, Management Information Systems, Economics, Mathematics and Statistics, Finance, Auditing, Consolidation, Financial Reporting Law, and Rules of Professional Conduct. 
in auditing and need to attend several advanced courses. In the first year of practical training, there are advanced courses in Company Law, Consolidation, Financial Accounting Law, Financial Statement Analysis, and Bookkeeping Techniques. In the second year candidates are required to follow advanced courses in Internal Auditing, External Auditing and Special Audit Topics. In the second year of the practical training candidates also need to write a paper on an imposed subject. In the third year of practical training candiclates need to attend an advanced course in Auditing, and an advanced course in Professional Conduct.

At the end of the three-year period the Training Committee reviews the practical training. When the Training Committee decides that the candidate has fulfilled all the traineeship requirements he is eligible for the final examination. This examination consists of both a written and an oral part. Although the Training Committee organizes advanced courses and tests, and supervises the Record of Practical Training, the main part of the preparation for the final examination consists of self-study. When a candidate meets all the aforementioned obligations, he will be sworn in to become a reviseur d'entreprises/bedrijfsrevisor.

\section{Appointment procedure}

Auditors are formally appointed by (a majority vote of) the shareholders at the Annual General Meeting. However, the appointment may be subject to approval by a party other than the party appointing the auditor. If an entity has a Workers' Council, this body is eligible to approve the appointment of the auditor. Further, the supervisory organs for companies subject to prudential control (e.g. banks, insurance companies, and listed companies) are also eligible to approve the appointment of the auditor. The period of appointment is fixed for three fiscal years, and is renewable without limitation for periods of three years. Audit firms face restrictions on advertising and unsolicited offering of services. In Belgium, all forms of advertising to the public in general are forbidden. Advertising on a local scale, if factual and objective, is however permitted. Furthermore, all forms of unsolicited offerings of services are prohibited.

\section{Auditor independence}

The most important part in the code of ethics concerns independence. It can be classified into legal actions to protect such independence in general, and rules on independence regarding a particular client. The general legal guidelines with respect to independence prohibit an auditor to become employed outside the auditing profession. Hence, Belgian auditors will lose their license when becoming employed outside the auditing profession. It is also forbidden to conduct activities incompatible with the dignity or independence of the profession. 
Independence with respect to a particular client is based on the principle that auditors should refuse to accept an engagement if they: (a) have been a director or manager of that client in the past three years; (b) have a personal relationship with the client; (c) have a commercial relationship with the client; (d) have a financial interest in the client; (e) render non-audit services to the client which could question their independence; and/or (f) become dependent, with regard to his fee-income, on particular clients. With respect to non-audit services, audit firms are not allowed to provide other services to an audit client within the same legal entity. In Belgium, however, audit firm networks provide services other than audit services through separate legal entities.

The professional body has wide powers to monitor its members. First, auditors are required to report the number of hours and the fees for all audits to the professional body, which reviews the adequacy of the audit fee and the audit hours spent. This requirement specifically aims at prohibiting low balling. Second, audit firms are subject to a peer review at least once every five years.

\section{Auditor liability}

In general, legal actions against the auditor can be undertaken by the auditee, its shareholders, and any involved third party. The interaction between the auditees' and auditors' liability positions is determined by the liability allocation regime. Belgium adopted a system of proportional liability, which is a system where the liability is placed upon the defendants according to their contribution to the damage.

In Belgium it is not possible to reduce the auditor's liability. There is no legal liability cap, which is a cap that reduces the auditor's liability in cases where auditors are exposed to civil liability initiated by the other contract party (the auditee), or in cases where auditors together with the auditee are exposed to civil liability initiated by the shareholders or any involved third party. It is also not possible to arrange a contractual liability cap, which is a liability cap that reduces the auditor's liability in cases where auditors are exposed to civil liability initiated by the other contract party (the auditee). A contractual liability cap is not relevant in cases where auditors together with the auditee are exposed to civil liability initiated by shareholders or any involved third party, since these parties are not contract parties.

Furthermore, the choice of legal form of an audit firm may influence the auditor's liability. In Belgium, audit firms can choose between the private limited liability company, (general) partnership and cooperative society. Audit firms cannot be organized in the form of public limited liability company. 


\section{A.3 Audit market regulation in Germany}

\section{A.3.1 Overview of the German auditing profession}

In Germany two types of auditors are allowed to perform statutory audits: Wirtschaftsprufer and vereidigte Buchprüfer. They do not possess equal rights with respect to the provision of audit services. Wirtschaffsprufer are entitled to conduct all statutory audits, whereas vereidigte Buchprufer are only allowed to conduct statutory audits of medium sized private limited liability companies. German law requires both Wirtschaftsprüfer and vereidigte Buchprüfer to be members of the Chamber of Auditors (Wirtschaftsprifferkammer), which is a public-law entity charged with the disciplinary control over the profession. The Chamber is under the supervision of the Federal Ministry of Commerce and in the individual states by the respective counterparts. The Chamber of Auditors regulates many aspects of the German auditing profession and is supported in this respect by the Institute of Auditors (Institut der Wirtschaftspriffer), a voluntary organization of auditors and audit firms. ${ }^{22}$ This Institute is principally involved in technical matters and enacts compulsory guidelines for her members.

According to the Act Regulating the Profession of Auditors (Act of 24 July 1961: Wirtschafisprüferordnung vom 24. juli 1961), all auditors need to work in public practice. They can either work as a sole-practitioner, work as a partner or employee of an audit firm, or work for certain associations of auditors (genossenschaftliche Prüfungsverbände, Prüfungsstellen von Sparkassen- und Giroverbänden, überortliche Prüfungseinrichtungen für öffentliche Körperschafien und Anstalten). In public practice, the principal task of an auditor is to audit annual accounts, to provide tax services, and to render management consultancy services. Auditors are also allowed to accept assignments with respect to trustee management and expert reporting if these activities are compatible with their work as an auditor. The influence of taxation matters on the German auditing profession is considerable. For example, most auditors are also qualified as tax advisor, and taxation matters form a considerable part of the educational programmes to qualify as an auditor.

In Germany, an audit requirement for large public limited liability companies was introduced in 1937, and for large private limited liability companies in 1969. Meanwhile, also banks, insurance companies and incorporated partnerships were required to have a statutory audit. The introduction of the Fourth EEC Directive in

22 Per 1 August 1994 , approximately $85 \%$ of all auditors are a member of the Institute of Auditors. Only about $50 \%$ of all audit firms are a member, but they employ almost $80 \%$ of all auditors working for audit firms. 
1985 required medium-sized public and private limited liability companies and incorporated partnerships to have their annual accounts audited.

\section{A.3.2 Audit market regulation ${ }^{23}$}

\section{Admission to the profession}

Under German law, as embodied in the Act of 24 July 1961, regulating the profession of auditors, candidates are eligible for inscription as an auditor in the professional register of the Chamber of Auditors when they passed the German auditor examination. Although the German federal government sets out the details for the auditor examination, the individual states grant the Wirtschaftsprüfer qualification to successful candidates. The qualification granted by one state is equally legitimate in other German states. The course of study leading to the Wirtschaftspriffer qualification consists mainly of self-study. The Chamber of Auditors does not offer an educational programme, and universities do not organize postgraduate programmes. Only the Institute of Auditors, and some private educational institutes or individual professors offer some courses to prepare for the final auditor examination.

The typical course of preliminary training for candidates wishing to commence training for the Wirtschaftspriffer qualification is a university education in Business Administration. Other academic studies acknowledged as preliminary training are (Business) Economics, Engineering, Law, and other studies with an accent on business matters. After their academic training candidates are required to follow a practical training period of five years. Within this period, candidates need to work at least four years in auditing practice.

In addition to this academic route, there are three other avenues for candidates to become eligible to sit for the auditor examination. The first of these three alternatives is to qualify as a tax advisor (Steuerberater) or vereidigter Buchprufer. In addition, a total period of five to about nine years of practical training is required. The candidates need to have worked as a tax advisor or vereidigter Buchprüfer for at least five five years, and they need to have at least four years of experience in auditing. The second alternative for candidates to become eligible to sit for the auditor examination, is to qualify as a tax advisor or vereidigter Buchprufer, and to have worked as such for at least 15 years. The third alternative is to have worked for at least ten years for an audit firm, and to have spent at least four years working in

2 In this paragraph, only the audit market regulation of Wirischaftspriffer is discussed because the study on competition in audit markets does not consider vereidigre Buchprijfer. The majority of statutory auditors are Wirtschaftspriffer. 
auditing. So, the total period of practical training of this alternative ranges from 10 to about 14 years.

After the period of practical training, candidates are eligible to sit for the auditor examination. During the practical training, candidates are not required to follow courses. Preparation for the final examination consists for the greater part of self-study, although candidates can follow some courses at the Institute of Auditors. These courses include most subjects of the auditor examination. ${ }^{24}$ The admission to the auditor examination will be granted by the Admittance Committee of the region, where the candidate is professionally established, or is practising. ${ }^{25}$ According to the 1961 Act, the Federal Ministry of Economic Affairs is responsible for conducting the auditor examination. They delegate this task to the individual states. Each state establishes an Examination Board, which conducts the actual examination. Although the examinations are organized by the individual states, they are intended to have a uniform level. When a candidate successfully completes the examination he will be appointed as an auditor after he takes an oath.

\section{Appointment procedure}

Auditors are formally appointed by (a majority vote of) the shareholders at the Annual General Meeting. However, the appointment is subject to approval by: (1) the supervisory authority for banks (Bundesaufsichtsambt für das Kreditwesen) in the case of banks, and (2) the supervisory authority for insurance companies (Bundesaufsichtsambt fü das Versicherungswesen) in the case of insurance companies. In contrast with Belgium, there is no fixed period with respect to the length of the appointment of the auditor. German audit firms face restrictions on advertising and unsolicited offering of services. All forms of advertising and unsolicited offerings are forbidden. However, an auditor may provide the name of his firm in academic articles, speeches, and seminars.

\section{A uditor independence}

Like in Belgium there are independence guidelines prohibiting an auditor to become employed outside the auditing profession. Hence, German auditors will lose their license when becoming employed outside the auditing profession. Furthermore, there are a number of regulations on independence with respect to a particular client. Such regulations impose that auditors should refuse to accept an engagement if they: (a)

24 The only subject not included in the course programme of the Institute of Auditors is "Tax Law. The reason being that $95 \%$ of all candidates are alreadly qualified as a tax advisor.

25. The Admittance Committee is a state government body, consisting of a representative of the State Ministry of Economic Affairs, a representative of trade and industry, and two auditors. 
have a personal relationship with the client; (b) have a commercial relationship with the client; (c) have a financial interest in the client; (d) render non-audit services which could question their independence; and/or (e) become dependent, with regard to fee-income, on particular clients. With respect to non-audit services, audit firms are not allowed to provide bookkeeping services to an audit client. Other services are allowed to be provided to an audit client within the same legal entity. With respect to the monitoring of audit fees, in Germany there are no explicit regulations on the calculation of audit fees, although auditors are obliged to charge a fair and reasonable fee. Furthermore, audit firms are not required to undergo peer reviews.

\section{Autitor liability}

In Germany, legal actions against the auditor can be undertaken by the auditee, but not by the shareholders or any involved third party. Furthermore, liability can be capped by law or by contract. There is a legal liability cap, which is only applicable in cases where auditors are exposed to civil liability initiated by the other contract party (the auditee). The legal liability cap is DM 500.000, -. A contractual liability cap is also allowed to be arranged in cases where auditors are exposed to civill liability initiated by the other contract party (the auditee). However, liability may not be capped at a higher level than the legal liability cap. The legal and contractual liability caps are only applicable to contract parties since it is not possible that auditors together with the auditee are exposed to civil liability initiated by the shareholders or any involved third party.

Furthermore, as stated earlier, the choice of legal form of an audit firm may influence the auditor's liability. Public limited liability company, private limited liability company, incorporated partnership, general partnership and limited partnership are the legal form which firms of statutory auditors are allowed to take in Germany.

\section{A.4 Audit market regulation in the Netherlands}

\section{A.4.I Overview of the Dutch auditing profession}

In the Netherlands, both registered auditors (registeraccountants) and certified accountants (Accountants-Administratieconsulenten) and are allowed to give a written opinion regarding annual accounts. Registered auditors were granted this right according to the 1962 Act on Registered Auditors (28 June 1962: Wet op de registeraccountants), which came into force in 1967. Registered auditors are listed in the register of their professional body, the Royal Dutch Institute of Registered 
Auditors (Koninklijk Nederlands Instituut van Registeraccountants). Certified accountants, associated in the Dutch Association of Certified Accountants (Nederlandse Orde van Accountants-Administratieconsulenten) were granted the right to perform audits according to the 1993 Act on Certified Accountants (6 August 1993: Wet op de Accountants-Administratieconsulenten). This 1993 Act is a substantial revision of the 1974 Act on Certified Accountants due to the implementation of the Eighth EEC Directive into Dutch legislation. Before the revision of the Act, certified accountants were not allowed to render auditing services. They mainly provided bookkeeping, tax, and consultancy services. Currently, the right for certified accountants to perform audits is only applicable to those who completed the new education programme for certified accountants or to certified accountants who enrolled in a transitional programme. The two professional bodies are public-law entities, and are charged with regulating the auditing profession. They are responsible for licensing statutory auditors and issuing auditing standards as authorative guidance for their members.

Both registered auditors and certified accountants are permitted to perform statutory audits as well as contractual audits. No limitations are placed on rendering non-audit services, as long as these activities are compatible with their audit services. ${ }^{26}$ Moreover, they are not required to work in public practice. Currently, only about $40 \%$ of the total number of auditors is engaged in public practice.

With respect to the statutory audit requirements, at the start of the period of study in 1970, banks, insurance companies, and pension funds were subject to an audit requirement. In 1971, according to the 1970 Act on Annual Accounts, large public limited liability companies were required to have a statutory audit. In 1973, this Act was extended to large private limited liability companies. The implementation of the Fourth EEC Directive in 1984 also required medium-sized public and private limited liability companies to have their annual accounts audited. For private limited liability companies, however, this requirement only came into force in 1989 after a five-year transitional period.

26 The audit services provided by registered auditors are statutory auditing and contractual auditing. Their non-audit services can be categorized as follows: performing reviews (beoordelingsopdrachen), providing agreed-upon procedures (specifiehe werkzaamhedem), compilation of financial statements (samenstellingsopdrachter), and providing consultancy services. 


\section{A.4.2 Audit market regulation ${ }^{27}$}

\section{Admission to the profession}

There are two educational programmes leading to qualification as a registered auditor. Candidates can either follow the education programme of the Royal Dutch Institute of Registered Auditors, or the education programme organized by universities. The education for registered auditors is, according to the Act on Registered Auditors, entrusted to the Royal Dutch Institute of Registered Auditors. The Institute established an Educational Board, responsible for their educational programme. In addition, an independent Examination Bureau was established, to monitor the final auditor examination, and the postdoctoral auditor examinations at the universities. The doctoral examinations, organized by the universities, are under the responsibility of their Faculties of Economics and Business Administration. ${ }^{28}$

The education programme of the Royal Dutch Institute of Registered Auditors, which will be referred to as NIVRA programme, extends over more than eight years of part-time study. Candidates follow the NIVRA programme, while already being employed with an audit firm or elsewhere. The typical way to enter the NIVRA programme is after completing secondary school ${ }^{29}$ Candidates can also enrol in the NIVRA programme after finishing a four-year course in accountancy or business administration in a higher school of vocational education.

The NIVRA programme consists of three stages. The first stage extends over two and a half year, and includes introductory subjects in Economics and Business Administration, Bookkeeping, Information Systems/Computer Science, (Tax) Law, Auditing, and Mathematics/Statistics. The second stage is a two-year general stage, including the subjects Management and Organization, Law, Finance, Information Systems/Computer Science, Management Accounting, Tax Law, Financial Accounting, and Introduction to Auditing. In the final stage, which extends over three and a half year, candidates need to pass tests in Advanced Financial Accounting, Administrative Organization, and Auditing. Candidates pass the final stage after

27 In this paragraph, only the audit market regulation of registered auditors is discussed. The study on competition in audit markets does not consider certified accountants because they were not eligible to conduct audits during (a large part of) the period of study.

${ }^{28}$ The university courses required for candidates to become eligible to follow the post-doctorall courses need to be approved by the Examination Bureau.

29 The required secondary school level is that of preparatory academic education. Candidates who finished other types of secondary education need to pass an entrance examination at the level of preparatory academic education. 
taking both written and oral tests in the required subjects, and after successfully defending a written paper.

Candidates can also follow a university education in Business Administration, and a postdoctoral programme, in order to become a registered auditor. The course of study for the university programme consists of a one-year preliminary course (propaedeuse), a three-year doctoral course, and a two-year postdoctoral course. ${ }^{30}$ The one-year preliminary course and the three-year doctoral course are offered by Dutch universities in a full-time, four-year degree programme in Bedrijfseconomie. ${ }^{31}$ After completion of the degree programme in Bedrijfseconomie, candidates start working at an audit firm or elsewhere and follow the postdoctoral programme on a part-time basis. This postdoctoral programme is equal to the final stage of the NIVRA programme.

After passing either the NIVRA programme or the university programme, candidates can apply for an inscription on the professional register of the Royal Dutch Institute of Registered Auditors. Together with their application, candidates need to confirm that they are not in bankruptcy, not placed under guardianship by court order, and not have been convicted of certain types of offence which prohibit rendering services as a registered auditor. When candidates meet all these requirements, they are eligible for inscription to become a registered auditor.

In contrast to Belgium and Germany, currently candidates are not required to have practical experience in auditing to achieve qualification as a registered auditor. Because of the implementation of the Eighth Directive, however, practical experience will become compulsory for candidates who qualify as an auditor after September 1999. These candidates are required to have at least three years of practical training in auditing.

\section{Appointment procedure}

Statutory auditors are formally appointed by (a majority vote of) the shareholders at the Annual General Meeting. There is no approval required by a party other than the party appointing the statutory auditor. Like in Germany, there is no fixed period with respect to the length of the appointment of the auditor. In the Netherlands, audit firms also face restrictions on advertising and unsolicited offerings. Since the nimeteen-

30 University Maastricht offers a post-doctoral programme of one year, whereas the Free University of Amsterdam offers a three-year programme. The length of the post-doctoral programme of a university depends on the subjects candidates were able to pass in the doctoral programme ai that university.

3 According to Zeff, van der Wel and Camfferman (1992), this term is almost synonymous with "business administration with a strong base of economic theory". 
eighties, advertising is allowed but should be limited to factual and objective information and needs to comply with professional ethics. All forms of unsolicited offerings are forbidden.

\section{Auditor independence}

Unlike Belgium and Germany, Dutch auditors will not lose their license when becoming employed outside the auditing profession. Regulation on independence with respect to a particular client imposes that auditors should refuse to accept an engagement if they: (a) have a personal relationship with the client; (b) have a commercial relationship with the client; (c) have a financial interest in the client; and/or (d) become dependent, with regard to his fee-income, on particular clients. With respect to non-audit services, audit firms are allowed to provide any services to an audit client within the same legal entity. Regarding the monitoring of audit fees, there are no explicit regulations on the calculation of audit fees. However, there is a general requirement that the fees should reflect the amount of work spent on the audit. Furthermore, audit firms are not required to undergo peer reviews.

\section{Auditor liability}

In the Netherlands, legal actions against the auditor can be undertaken by the auditee, its shareholders, and any involved third party. The interaction between the auditees' and auditors' liability positions is in principle determined by a system of proportional liability. There is no legal liability cap, but there is the possibility to arrange a contractual liability cap. Finally, Dutch audit firms are allowed to take any legal form, although the Dutch professional bodies are entitled to restrict in certain circumstances the legal forms which auditing firms may take. In practice, however, the professional bodies seem to be liberal on this issue.

\section{A.5 The effects of regulation on audit markets}

In this section we will compare the audit market regulations in Belgium, Germany and the Netherlands and outline the potential effects of the regulations on each of the three audit markets. The focus will be on regulations affecting competition. Hence, first the differences in entry requirements will be discussed, and subsequently the regulations with respect to the appointment procedure, and auditor independence will be discussed. Note that the comparison of regulatory regimes applies to the period 1970-1994.

According to the Eighth Directive of the European Union, statutory auditors are required to have at least three years of practical experience in auditing. Although 
all three countries have implemented the Eighth Directive, there is a difference with respect to the date of operation of this practical experience requirement. For over several decades, Belgium and Germany have a practical experience requirement, whereas in the Netherlands, a practical experience requirement will come into operation in September 1999. Furthermore, as a consequence of their practical experience requirement, Belgium and Germany require candidates to first attain a traineeship before starting the educational programme. Such a requirement impedes entry to the profession. Hence, with respect to practical experience, it can be concluded that the requirements are more strict in Belgium and Germany. In addition to achieving a qualification, in Belgium and Germany auditors are required to maintain sufficient up-to-date experience through requirements for minimum levels of audit work. In the Netherlands, auditors are allowed to keep their license when leaving public practice. Hence, it can be concluded that also on this point Belgium and Germany have more strict entry requirements than the Netherlands.

With respect to the appointment procedure of statutory auditors, one of the main differences among the three countries is the length of the appointment. In Belgium, the length of the appointment of the auditor is a fixed period of three years, whereas in Germany and the Netherlands there is no regulation on the length of the appointment. Regulations that specify a (long) period of appointment can be expected to impede competition between audit firms, since auditees are not able to change auditors within that specified period. Another regulatory difference affecting the appointment of auditors concerns advertising. Although in all three countries audit firms face restrictions on advertising, the Netherlands seems to have the most liberal regime. In Belgium and Germany all forms of advertising to the public in general are forbidden, although in Belgium advertising on a local scale, if factual and objective, is permitted. Since the end of the nineteen-eighties, advertising is allowed in the Netherlands, but should be limited to factual and objective information and needs to comply with professional ethics. Restrictions on advertising influence the nature of competition in an audit market, since for example new entrants to the market will have more difficulty to establish a reputation and/or a brand name. This will make it more difficult for entrants to compete with incumbent audit firms. Since the Netherlands has the most liberal regime regarding advertising, it can be expected that this will have a positive effect on the level of competition in the Dutch audit market.

An important aspect of regulation regarding auditor independence concerns fee setting. In general regulations in this area attempt to prohibit or restrict low balling. Of the three countries covered, only in Belgium auditors are required to report the number of hours and the fee for an audit to the professional body, which reviews the adequacy of both figures. Although in all three countries auditors are obliged by law or the ethical code to charge a fair and reasonable fee, which may not 
depend on the result of the audit, the Belgian requirement implies a far more strict enforcement of this general rule. Regulation restricting fee setting limits the competition for (new) clients on the basis of price. Because the Belgian fee regulation is more strict than in the other two countries it can be expected that its negative effect on competition will be the most profound in Belgium. Differences in liability regimes in the three countries are not considered as having an effect on competition. It can be argued that liability insurance fees can be priced in the audit.

Considering the different regulatory regimes, it can be expected that the Dutch audit market is the most competitive of the three markets. The entry requirements are less, advertising is generally allowed, there is no fixed auditor tenure, and the setting of fees is nearly without restrictions. This more liberal set of regulations should be reflected in a number of audit market characteristics. In chapter 4 , competition is measured by looking at static as well as dynamic measures of market structure. However, additional evidence can be provided on the degree of competition in these three audit markets. Hence, evidence will be provided on national data on the number of auditors admitted to the profession, the total number of auditors, the age of qualification of auditors, and charge-out ratios of auditors.

FEE (1988) reports for a number of countries the average number of candidates admitted to the profession each year. The results reported are: Belgium 180; Germany 200; and the Netherlands 375. Hence, in absolute terms the entry to the Dutch profession is the highest. In relative terms the same holds considering that the German economy is much larger than the Dutch economy, and that the Belgian economy is only slightly smaller. FEE (1988) also reports that of the 17 countries covered, Germany has the highest age of qualification (i.e. 35 ). This can be expected considering the German entry requirements.

The effects of entry should be reflected in the total number of auditors active in an audit market. The total numbers of auditors active in the three markets in 1990 are given in European Commission (1996, p.120): Belgium 711; Germany 6,625; and the Netherlands 2,770 . Of course, these figures should be scaled by the size of the economy. Morse (1993) has scaled the number of auditors active in national markets by the size of the population. His results are: Belgium 0.000069; Germany 0.000096; and the Netherlands 0.000450 . Again, these figures confirm the relatively large size of the Dutch audit profession, which is consistent with relatively easy entry.

Ultimately, competition can be expected to affect the prices, or fees, charged by auditors. Therefore, we will provide information on the charge-out ratios of auditors in the three countries. It should be noted that the level of charge-out ratios is also affected by factors other than competition. Preferably, to measure the effects of competition one would also need information on the cost structures of audit firms in the three countries. In combination with fees charged, cost information can give 
an indication of the economic rents of audit firms. However, data on audit firm fees and cost structures are hardly available.

The data limitations mentioned should be noted when reading the following results. In TABLE A.1 the charge-out ratios of the Big Six firms in Belgium, Germany and the Netherlands are given. The table contains both data on total fee income and on audit fee income. In the Netherlands, the total annual fee for each professional is $65000 \mathrm{ECU}$ and the annual audit fee for each auditor is 210000 ECU. The results show that for both categories of charge-out ratios the Netherlands has the lowest values. These figures are again consistent with the hypothesis that the Dutch audit market is the most competitive of the three markets.

\section{TABLE A.1}

Charge-out ratios of the Big Six audit firms in Belgium, Germany and the Netherlands in 1989

Total fee ${ }^{\mathrm{a}}$

Number of professionals ${ }^{a}$
Audit fee $/$ Number of auditors ${ }^{b}$
Belgium

Germany

The Netherlands
$72000 \mathrm{ECU}$

$99000 \mathrm{ECU}$

$65000 \mathrm{ECU}$
$325000 \mathrm{ECU}$

$288000 \mathrm{ECU}$

$210000 \mathrm{ECU}$

a Source: NERA (1992).

b Source: Membership lists of the Institu des Reviseurs d"Entreprises/Mnstituut der Bedrif/srevisorev, the Wirtschaffsprifferkammer and the Koninklijk Nederlands Irstitur van Regisferaccoumtants. 


\section{Appendix B}

\section{Procedures used in compiling the data}

1. Each audit firm listed in a membership list is counted as a firm. The total number of auditors working in public practice for an audit firm is used as the firm size measure. Auditors can be employees or partners of an audit firm.

2. If auditors work for more than one audit firm, they are counted with the largest of the firms. The implication of this is that an audit firm with all auditors also working for one or more larger firms, is treated as an audit firm with zero auditors (a silent firm).

3. Comparison of continuing firms in successive membership lists produces results on market share changes.

4. Pure name changes of audit firms were determined as accurately as possible and the firms in question were treated as continuing firms.

5. Comparison of the successive membership lists produces data on the number of entering and exiting firms in each period. New firms on the successive list are recorded as entering firms, and firms no longer appearing on the successive list are recorded as exiting firms.

6. For each entering firm it is possible to establish whether the auditors working there: (1) previously worked for another audit firm, or (2) newly entered the register of the professional body or, if applicable, were previously working

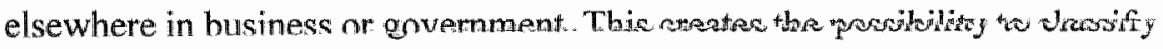
an entering firm as a divestiture of an existing firm, or as a firm established by auditors previously not active in the audit market. This was not always straightforward as auditors working for entering firms sometimes had different origins (e.g. one or more auditors are newly qualified and one or more auditors come from existing audit firms, or if applicable, from business). These firms were classified on the basis of the majority origin of the partners, or if necessary, the majority origin of all auditors. In the absence of a majority on both counts the firm was classified, in that order and where applicable, as a split-off of an existing firm, or an entrant founded by new auditors or, if applicable, auditors from business.

7. For the exiting firms it is possible to establish whether the auditors working there: (1) went to work for another audit firm, i.e. were taken over by another firm, or (2) no longer work for an audit firm, e.g. retired or ceased to be auditors. Here also were some classification problems with 'mixture' 
cases. Again a majority of partners, and if necessary a majority of all auditors rule was used to classify exits as merger exits or as 'pure' exits. If no majority materialized, the exit was classified as a 'merger' exit.

8. A merger of two audit firms is registered as an exit of the smaller of the two amalgamating firms and an acquisition by, and a continuation of, the largest firm. If both firms were of the same size, the order of the old firm names in the new name determined the acquiring firm. If that did not help, arbitrarily, alphabetical order of the old firms names determined the acquiring firm. Note that this difficulty was rare. 


\section{Chapter 5}

\section{Summary and discussion}

\subsection{Introduction}

This dissertation examined auditor careers and audit markets from an economic perspective. This final chapter provides an overview and discussion of the three empirical studies on auditor careers and audit markets included in this dissertation. To that end, section 5.2 provides a summary of these three studies. Section 5.3 discusses the practical implications and the strengths and weaknesses of this research, and concludes with some suggestions for further research.

\subsection{Summary}

This dissertation contributed to auditing research by examining the economics of auditor careers and audit markets. The economics of auditor careers has been addressed by studies on the career advancement of auditors and on the interorganizational mobility of auditors. The economics of audit markets has been addressed by an analysis of market structure of three audit markets. A summary of the three empirical studies is provided below.

\section{Career advancement in audit firms}

A study on career advancement is undertaken to assess the influence of factors affecting the advancement to partnership in audit firms. Career advancement is measured in terms of both promotion to partner and promotion velocity. Education, age at qualification, audit firm size and change of audit firm were used to explain differences in career advancement. Data on the career advancement of auditors have been obtained from the membership lists of the Dutch professional body of auditors, which include employer and position for all auditors. The career advancement of the auditors under study was examined in the period 1970-1998. 
Education can be regarded as an important explanatory variable in analysing the career advancement of Dutch auditors since the Netherlands provides a unique setting to test differences between university and non-university education. The univariate results showed that university-educated auditors are more likely to become partners and advance faster towards partinership. Nevertheless, the multivariate analysis showed that greater age at qualification decreases the probability of progressing to partnership. Since university graduates qualify at an earlier age, the main reason behind the enhanced performance of university-educated auditors appears to be their more rapid advancement towards qualification as auditors.

The results further indicated that both audit firm size and change of audit firm are negatively related to the probability of achieving partnership. Also, audit firm size and change of audit firm are negatively related to promotion velocity. In contrast with expectations from human capital theory, auditors having a high study velocity do not have a higher promotion velocity. A possible explanation is that audit firms use an age threshold, requiring auditors to have some minimum age in order to be considered experienced enough to advance to partnership. As indicated by a sensitivity analysis, these results also hold for a subsample of the audit market: the Big Six audit firms. The findings further indicated that university educated auditors, as compared with non university-educated auditors, are more likely to leave the audit firm and at an earlier stage if they cannot attain a partnership. This may follow from their more general education which enhances the job-opportunities for university graduates outside audit practice. Finally, the analyses showed that the actual promotion probability for newly qualified auditors is $32 \%$ (partners vs. all auditors in the cohorts), and $51 \%$ for auditors employed with audit firms.

\section{Inter-organizational auditor mobility}

By analysing 13 annual cohorts of auditors, chapter 3 provided evidence of the inter-organizational mobility of auditors. Event history analysis was used to analyse the careers of the subjects under study. This statistical technique is particularly suited for longitudinal mobility data since it enables to study the timing of inter-organizational moves and accounts for time-varying explanatory variables. Similar to the study on the career advancement of auditors, data were obtained from the membership lists of the Dutch professional body of auditors. Furthermore, the inter-organizational mobility of the auditors under study was examined in the period 1970-1998.

The analyses address a model of total inter-organizational mobility, and the consequences of client-specific investments, the existence of audit quality 
differences, and the use of up-or-out promotion systems. A piecewise constant exponential model, including personal and organizational variables, was estimated for the total transition rate function. This model provided evidence on the nonmonotonic relationship between job-tenure, work experience and interorganizational auditor mobility. That is, auditor mobility increases sharply in the first three years, after which there is a gradual decrease. The findings further indicated that education is positively related to auditor mobility. Universityeducated auditors, having a more general education are more likely to experience inter-organizational mobility than non-university educated auditors. Furthermore, strong evidence is presented on the negative association between auditor mobility and both promotion to partnership and firm founder. Apparently, careers become in a steady phase after a promotion to partner or after the founding of one's own audit firm. Evidence is also provided on the positive relationship between auditor mobility and the date of qualification as an auditor. Auditors who qualified as auditors in more recent years were more likely to experience mobility, probably because of the increased competition over time in the Dutch audit market, which provided them with more opportunities to move. Furthermore, inconclusive evidence is found on the influence of the auditor's age at qualification, the number of previous jobs, and audit firm size. The age at qualification is negatively related to the total hazard rate, but the specific tests indicated that this only holds for certain types of moves. The number of previous jobs was not significantly related to the total hazard rate.

The results with respect to the association between audit firm size and total inter-organizational mobility are inconclusive, probably because of the simultaneous influences of client-specific investments, audit quality and up-or-out systems. Therefore, specific tests were conducted on the influence of the variables on the nature of inter-organizational mobility. A distinction was made between three types of employment: Big Six audit firms, non-Big Six audit firms and business/government. In this way, the effects of client-specific investments, audit quality and up-or-out promotion systems could be identified separately, enabling the investigation of these three factors from a mobility perspective. In particular, the findings indicated that in line with human capital theory, the probability of auditor mobility decreases as auditors develop more client-specific human capital owing to client-specific investments and industry specialization. This indicates that human capital is closely associated with the production of audit services. Large audit firms trying to obtain economies of scale by specializing in certain industries or stimulate client-specialization by requiring auditors to specialize in certain types of clients, reduce the mobility opportunities of their auditors. On the other hand, however, quality differences between large and small firms provide 
auditors of large firms with more opportunities to move. That is, the results indicate that upward auditor mobility is significantly lower than downward auditor mobility, probably because large audit firms provide a higher level of audit quality as compared to small audit firms. Moreover, up-or-out promotion systems are more frequently used by large audit firms than by small audit firms, creating additional mobility out of large audit firms. As expected, small audit firms have less incentives to maintain up-or-out promotion systems than large audit furms. Size restrictions prevent them from using these type of promotion systems.

\section{Competition in audit markets}

The economics of audit markets has been addressed by a study on competition in the Belgian, German and Dutch audit markets. This study provided a static as well as a dynamic empirical analysis of the structure of these three audit markets. In addition, the regulatory regimes of these three countries were analysed. The aim was to explain differences in audit market structure between Belgium, Germany and the Netherlands as a result of their regulatory regimes. Results were presented for audit firm entry and exit, and market share mobility. The study used the total number of auditors engaged with audit firms as a measure of audit firm size. Data on the number of auditors per audit firm were obtained from the membership lists of the professional bodies of statutory auditors in the three countries.

The analysis of the regulatory regimes revealed that the Dutch audit market can be expected to be more competitive than the Belgian and the German audit markets. Compared with Belgium and Germany, in the Netherlands entry requirements are less, advertising in general is allowed, there is no fixed auditor tenure, and the setting of fees is nearly without restrictions. Belgium and Germany have about equally strict regulatory regimes. Although their regulations differ at some points, these differences are less profound than the differences of either Belgium or Germany with the Netherlands.

The findings of the analyses on the structures of the three audit markets indicated that the more liberal Dutch audit market exhibits the highest dynamic measures of market structure and the highest concentration. Accordingly, the results showed that high concentration can go hand in hand with high market share mobility, and high audit firm entry and exit. The results for market share mobility also held for an analysis only including the largest audit firms. This study therefore concluded that compared with a static seller concentration analysis, an analysis of audit market dynamics provides a better description of the degree of competition in audit markets. 


\subsection{Discussion}

\subsection{Practical implications}

The conclusions of the empirical studies on auditor careers and audit markets have several implications for auditing practice. With respect to auditor careers, the results of the studies on career advancement in audit firms and inter-organizational mobility are not only relevant for those who are (considering) pursuing a career in auditing, but also for those who are concerned with the planning and management of human resources within audit firms.

To start with individual auditors, the results on the comparison of educational avenues reveals that university-educated auditors more often advance to a partnership in audit firms. However, this seems to be driven by their younger age at qualification. Study velocity appeared to be an important determinant of career advancement. Furthermore, the results on inter-organizational auditor mobility have implications for auditors intending to change employers. The trend towards industry specialization in auditing therefore has implications for individual auditors. A higher degree of industry specialization results in more client-specific human capital, which results in a lower probability of moving. Thus, auditors who want to have optimal freedom in changing employers need to consider the consequences of industry specialization. Moreover, the quality difference between large and small audit firms implies that auditors who have been with small audit firms too long, have a lower probability of changing to a large audit firm. If individual auditors want to be engaged with a large audit firm in their career, they should start with a large firm.

Audit firms can benefit from the conclusions on the two studies on auditor careers by obtaining information on several characteristics of those auditors who advanced to partnership and those auditors who have a high probability of interorganizational mobility. Audit firms are able to compare their internal promotion and turnover probabilities with those of the audit market as a benchmark. Furthermore, the results on the timing of auditor mobility and the influence of client-specific investments on the probability of moving are useful for human resource planning in audit firms. The trend towards more industry specialization will make auditors less mobile.

Since the study on career advancement in audit firms compares university with non-university education the results are also relevant for professional accountancy bodies having a non-university educational avenue or considering introducing such an avenue. First, the long period of study of the non-university education programme appears to decrease the promotion probabilities of these 
auditors. Second, their educational programme, focussing on on-the-job training instead of on broad education, appears to decrease the probability of interorganizational mobility of non-university educated auditors.

The results of the audit markets study is reason for several policy issues. The auditing profession experienced a brief period of turbulent changes at the end of the nineteen-eighties. The Big Eight audit firms merged into the Big Six. This raised concerns about the implications of these mega-mergers on the level of competition in the audit market. Fears were expressed that the mergers could restrict the choice of auditor for the larger entities leading to higher audit fees. A better understanding of the nature of audit markets will contribute to this issue. The study on audit market structure shows that dynamic measure of market structure provide a better explanation for the level of competition in audit markets than static measures of market structure. That is, a comparison of three audit markets indicates that the audit market with the most liberal regulatory regime exhibits the highest market share mobility and audit firm entry and exit and the highest concentration. Hence, high levels of concentration do not have to indicate limited competition since they can coexist with high dynamic measures of market structure. This is supported by the views expressed by the profession of increasing ("unhealthy") competition while concentration levels also increased. The European Commission expressed their concerns, and initiated a study, on the recent merger between the two Big Six audit firms Coopers \& Lybrand and Price Waterhouse. The current study shows that such assessments need to be based on a dynamic perspective of market structure, such as entry and exit of firms and market share transfers, instead of the current focus on static concentration.

\subsubsection{Strengths and weaknesses}

\section{Auditor careers}

The studies on auditor careers contribute to the existing literature in several ways. First, following organizational studies on career advancement and interorganizational mobility, the studies on auditor careers focus on complete cohorts of auditors and follow them over a long career horizon. Hence, because not only those auditors who are employed in (large) audit firms are considered, a distinction could be made between career advancement and inter-organizational mobility of auditors at large and small audit firms and between auditors in- and outside public practice. Also, complete cohorts permitted the identification of actual promotion and mobility probabilities in auditing. The much longer career 
horizon, as compared with previous research, enabled the analysis of complete career histories of individual auditors, and not only their first career stages.

Second, the study on inter-organizational auditor mobility further contributed to the existing auditing literature by opening the "black box" of audit firms. Previous studies on audit markets viewed audit firms as single entities while this study' examined the 'traditional' auditing issues audit quality and clientspecific investments for the first time from an auditor mobility perspective. Until now, client-specific investments have been addressed by studies on industry specialization. These studies generally examined auditor concentration across different industries and provide evidence of industry specialization by large audit firms [see, e.g. Craswell, Francis and Taylor (1995)]. The study on interorganizational mobility extended this area of research by providing evidence of industry specialization by large audit firms from an auditor mobility perspective. Audit quality has been investigated by previous studies from various perspectives. By comparing audit fees, litigation records and error detection probabilities of large and small audit firms, by analysing stock market reactions of companies changing to smaller audit firms examining, or by comparing the relationship between management earnings forecast and audited, reported earnings of large and small audit firms, overall, consistent evidence is provided that larger firms provide higher-quality audits. This study acknowledges that audit services are delivered by individual auditors and that the quality differences on the product market result in quality differences on the factor market. The study on interorganizational mobility provides additional evidence of the quality difference between large and small audit firms from an auditor mobility perspective. Accordingly, the analysis of these two issues from a mobility perspective leads to a fuller understanding of these phenomena.

A third strength of the study on inter-organizational mobility is the use of event history analysis. Previous studies examined single turnover decision while career mobility is a dynamic process where variables change over time and auditors can have more inter-organizational moves during their career. Event history analysis captures these dynamic characteristics by analysing time intervals between successive career events.

To fully evaluate the results and the implications of the two studies on auditor careers, also their weaknesses need to be considered. First, the data on auditors careers were obtained from secondary sources, i.e. membership lists of professional bodies. Although these lists include all auditors and list their employer and position, information on other important aspects of careers, such as information on salaries and evaluations by superiors was not obtained. Such 
information would provide more detailed information on whether auditors move to a better position, or whether moves were voluntary or involuntary. With this information even more detailed analyses on auditor careers could be performed.

Second, careers were analysed from the time of inscription as an auditor. Therefore, complete careers of auditors are analysed, but the career before individuals became auditors is not taken into account. This might especially influence the results on inter-organizational mobility. Individuals can experience mobility before they qualify as auditors. A mitigating factor in this respect will be the traineeship-arrangements between individuals and audit firms. Potential auditors engage in traineeships with their employers who will bear the costs of auditor education. This will serve as a bond between employees and employers to maintain the employment relationship at least until individuals finish their studies and become licensed as auditors. So, this part of an individual's career can be expected to show little mobility. Furthermore, employees" audit responsibilities can only be met when they are licensed as an auditor. So, their activities will change after qualifying as auditors. With respect to career advancement this will not influence the results since audit firms generally require individuals to be auditors to be able to become a partner. Therefore, this is not thought to contaminate the results presented on auditor careers

\section{A udit markets}

The study on audit markets makes two major contributions. First, it analyses audit market structure by means of a dynamic approach, including audit firm entry and exit and market share mobility. As explained before, compared with a static seller concentration analysis, an analysis of audit market dynamics provides a better description of the degree of competition in audit markets. Second, complete audit markets were studied. This enabled the calculation of accurate measures of market structure. Most previous studies automatically focussed on large audit firms because data on smaller audit firms were difficult to obtain. This led to truncated audit firm samples and upward-biased seller concentration measures of audit markets.

A few weaknesses need to be considered. First, economic theory is yet not very precise about the link between observed market share mobility, entry and exit, and the degree of rivalry in a market. The interpretation of the results in this study are based on the general notion that market instability reflects stiff competition. Information on cost structures and profit margins of audit firms would provide evidence on this relationship. Second, it is possible that an audit fee-income measure is superior to the headcount measure used in this study. 


\subsubsection{Suggestions for further research}

The link between auditor careers and audit markets appears to be a promising area of research. More detailed analyses on auditors who leave their current firm and found their own firm would give more insight into the dynamics of audit markets as a result of individual career decisions. Do these auditors leave their firm voluntarily or do they have to leave because of up-or-out practices? Such analysis would greatly benefit from information on salaries of auditors, and evaluations by superiors. Additionally, industry-related variables, such as audit market structure, and market growth, and firm-related variables, such as number of partner positions, market shares and audit firm profits, would provide further insight into the consequences of client-specific investments, the existence of audit quality differences, and the use of up-or-out promotion systems. This would enable research on the use of up-or-out promotion systems in times of market growth or decline, or research on career advancement of auditors or audit quality differences between audit firms under changing market conditions. Also, these data would enable research on the incentives and conditions to start a new audit firm. Are these decisions driven by up-or-out practices, market growth or, for example, industry specialization?

Furthermore, future studies could conduct even more specific analysis on the relationship between mobility and type of organization, with individual firms as the subject of study. In this respect, a link could be made with internal labour markets to investigate which types of firms predominantly use their internal labour market to staff positions and which types of firms staff through lateral entry. Furthermore, by examining client portfolios of audit firms, future research could analyse the effects of client-specific investments in up-or-out decisions. That is, according to human capital theory, it can be expected that auditors who possess a high level of firm-specific human capital, and are forced to leave their audit firm after a negative partner decision, will move to clients to retain the benefits of their client-specific investments.

Moreover, analysing individual firms will provide insight into differences between firms in the acquisition of client-specific human capital, or in up-or-out policies. Also, a link could be made with internal labour markets to investigate which types of firms predominantly use their internal labour market to staff positions and which types of firms staff through lateral entry. These analyses would then also give more insight in the management of audit firms. 


\section{References}

Abdel-Khalik, A.R. and I. Solomon (eds.), 1988, Research opportunities in auditing: The second decade, Sarasota: American Accounting Association.

Alford, R.M., J.R. Strawser and R.H. Strawser, 1990, Does graduate education improve success in public accounting?, Accounting Horizons 4 (1), pp. 69 76.

Allison, P.D., 1984, Event history analysis: Regression for longitudinal event data, Newbury Park: Sage Publishers.

American Accounting Association, 1986, Committee on the Future Structure, Content, and Scope of Accounting Education (The Bedford Committee), Future Accounting Education: Preparing for the Expanding Profession, Issues in Accounting Education 1 (1), pp. 168-195.

Anderson, J.C., E.N. Johnson and P.M.J. Reckers, 1994, Perceived effects of gender, family structure, and physical appearance on career progression in public accounting: A research note, Accounting, Organizations and Society 19 (6), pp. 483 491.

Aranya, N. and K.R. Ferris, 1984, A reexamination of accountants" organizational-professional conflict, The Accounting Review 59 (1), pp. 1 15.

Aranya, N., R. Lachman and J. Amernic, 1982, Accountants' job satisfaction: A path analysis, Accounting, Organizations and Society 7 (3), pp. 201-215.

Arnold, H.J., 1982, Moderator variables: A clarification of conceptual, analytic, and psychometric issues, Organizational Behavior and Human Performance 29 (2), pp. 143-1.74.

Arnold, H.J. and D.C. Feldman, 1982, A multivariate analysis of the determinants of job turnover, Journal of Applied Psychology 67 (3), pp. 350-360.

Ashton, A.H., 1991, Experience and error frequency knowledge as potential determinants of audit expertise, The Accounting Review 66 (2), pp. 218239. 
Baldwin, J.R, 1995, The dynamics of industrial campetition: A North-American perspective, Cambridge: Cambridge University Press.

Baldwin, J.R. and P.K. Gorecki, 1989, Measuring the dynamics of market structure: Concentration and mobility statistics for the Canadian manufacturing sector, Annales d"Économie et de Statistique 4 (15/16), pp. 315-332.

Baldwin, J.R. and P.K. Gorecki, 1991, Firm entry and exit in the Canadian manufacturing sector, 1970-1982, Canadian Journal of Economics 24 (2), pp. $300-323$.

Baldwin, J.R. and P.K. Gorecki, 1994, Concentration and mobility statistics in Canada's manufacturing sector, The Journal of Industrial Economics 42 (1), pp. 93-101.

Barkman, A.I., J.E. Sheridan and L.H. Peters, 1992, Survival models of professional staff retention in public accounting firms, Journal of Managerial Issues 4 (3), pp. 339-353.

Baron, J.N. and W.T. Bielby, 1980, Bringing the firms back in: Stratification, segmentation, and the organization of work, American Sociological Review 45 (5), pp. 737-765.

Beattie, V. and S. Fearnley, 1994, The changing structure of the market for audit services in the UK: A descriptive study, British Accounting Review 26 (4), pp. 301-322.

Beatty, R.P., 1989, Auditor reputation and the pricing of initial public offerings, The Accounting Review 64 (4), pp. 693-709.

Beatty, R.P., 1993, The economic determinants of auditor compensation in the initial public offerings market, Journal of Accounting Research 31 (2), pp. 294-302.

Becker, G.S., 1964, Human capital: A theoretical and empirical analysis, with special reference to education, New York: Columbia University Press.

Benke, R.L. and J.G. Rhode, 1980, The job satisfaction of higher level employees in large certified public accounting firms, Accounting, Organizations and Society 5 (2), pp. 187-201.

Benston, G.J., 1985, The market for public accounting services: Demand, supply and regulation, Journal of Accounting and Public Policy 4 (1), pp. 33-79.

Bhamornsiri, S. and R.E. Guinn, 1991, The road to partnership in the "big six" firms: Implications for accounting education, Issues in Accounting Education 6 (1), pp. 9-24.

Biggs, S.F. and J.J. Wild, 1985, An investigation of auditor judgment in analytical review, The Accounting Review 60 (4), pp. 607-633. 
Blank, M.M., P.H. Siegel and J.T. Rigsby, 1991, Determinants of international CPA firm orientation among accounting students, British Accounting Review 23 (4), pp. $281-300$.

Bline, D.M., D. Duchon and W.F. Meixner, 1991, The measurement of organizational and professional commitment: An examination of the psychometric properties of two commonly used instruments, Behavioral Research in Accounting 3, pp. 1-12.

Blossfeld, H.P. and G. Rohwer, 1995, Event history analysis: Statistical theory and application in the social sciences, Hillsdale: Lawrence Erlbaum Associates.

Borland, J. and J. Lye, 1996, Matching and mobility in the market for Australian rules football coaches, Industrial and Labor Relations Review 50 (1), pp. $143-158$.

Buijink, W.F.J., 1992, Empirical financial accounting research: Compliance with regulation, distributional properties of financial ratios and demand for external auditing, PhD Dissertation 92-5, Maastricht: Unversity of Limburg.

Buijink, W.F.J., S.J. Maijoor and R.H.G. Meuwissen, 1998, Competition in auditing: Evidence from entry, exit and market share mobility in Germany and the Netherlands, Contemporary Accounting Research 15 (3), pp. 385404.

Bullen, M.L. and E.G. Flamholtz, 1985, A theoretical and empirical investigation of job satisfaction and intended turnover in the large CPA firm, Accounting, Organizations and Society 10 (3), pp. 287-302.

Campbell, T.L. and D.W. McNiel, 1985, Stochastic and nonstochastic determinants of changes in client-industry concentrations for large public accounting firms, Journal of Accounting and Public Policy 4 (4), pp. 317. 328.

Carlton, D.W. and J.M. Perloff, 1994, Modern industrial orgamization, Second edition, New York: Harper Collins.

Carroll, G.R., 1983, Dynamic analysis of discrete dependent variables: A didactic essay, Quality and Quantity 17 (4), pp. 425-460.

Carroll, G.R. and K.U. Mayer, 1986, Job-shift patterns in the Federal Republic of Germany: The effects of social class, industrial sector, and organizational size, American Sociological Review 51 (3), pp. 323-341.

Caves, R.E. and M.E. Porter, 1978, Market structure, oligopoly, and stability of market shares, The Journal of Industrial Economics 26 (4), pp. 289-313.

Chow, C.W., 1982, The demand for external auditing: Size, debt and ownership influences, The Accounting Review 57 (2), pp. 272-291. 
Christiansen, M. and A. Lof,, 1992, Big players and small players: A study of increasing concentration in the Danish market for auditing services, European Accounting Review 1 (2), pp. 277-301.

Chung, D.Y. and W.D. Lindsay, 1988, The pricing of audit services: The Canadian perspective, Contemporary Accounting Research 5 (1), pp. 19 46.

Clarke, R., 1985, Industrial economics, Oxford: Basil Blackwell.

Colarelli, S.M., R.A. Dean and C. Konstans, 1987, Comparative effects of personal and situational influences on job outcomes of new professionals, Journal of Applied Psychology 72 (4), pp. 558-566.

Cotton, J.L. and J.M. Tuttle, 1986, Employee turnover: A meta-analysis and review with implications for research, Academy of Management Review 11 (1), pp. 55-70.

Craswell, A.T., J.R. Francis and S.L. Taylor, 1995, Auditor brand name reputations and industry specializations, Journal of Accounting and Economics 20 (3), pp. 297-322.

Craswell, A.T. and S.L. Taylor, 1991, The market structure of auditing in Australia: The role of industry specialization, Research in Accounting Regulation 5, pp. 55-77.

Crooks, L. and D. Rock, 1979, Career progress of MBAs seven years after graduation, GMAC handbook: Research summaries, Graduate Management Admissions Council.

Curry, B. and K.D. George, 1983, Industrial concentration: A survey, The Journal of Industrial Economics 31 (3), pp. 203-255.

Dalton, D.R., 1995, Human resource management and employee turnover and transfer: What we know is not always what we need, In: G.R. Ferris, S.D. Rosen and D.T. Barnum (eds.), Handbook of human resource management, Oxford: Blackwell Publishers, pp. 615-629.

Dalton, D.R., J.W. Hill and R.J. Ramsay, 1997a, Women as managers and partners: Context specific predictors of tumover in international public accounting firms, Auditing: A Journal of Practice and Theory 16 (1), pp. 27-50.

Dalton, D.R., J.W. Hill and R.J. Ramsay, 1997b, The threat of litigation and voluntary partner/manager turnover in big six firms, Journal of Accounting and Public Policy 16 (4), pp. 379-413.

Daiton, D.R. and D.J. Mesch, 1990, The impact of flexible scheduling on employee attendance and turnover, Administrative Science Quarterly 35 (2), pp. 370-387. 
Dalton, D.R. and W.D. Todor, 1993, Turnover, transfer, absenteeism: An interdependent perspective, Journal of Management 19 (2), pp. 193-219.

Danos, P. and J.W. Eichenseher, 1982, Audit industry dynamics: Factors affecting changes in client-industry market shares, Joumal of Accounting Research 20 (2-II), pp. 604-616.

Danos, P. and J.W. Eichenseher, 1986, Long-term trends toward seller concentration in the U.S. audit market, The Accounting Review 61 (4), pp. 633-650.

Davidson, R.A. and D. Neu, 1993, A note on the association between audit firm size and audit quality, Contemporary Accounting Research 9 (2), pp. 479488.

Davies, S.W. and P.A. Geroski, 1997, Changes in concentration, turbulence, and the dynamics of market shares, The Review of Economics and Statistics 79 (3), pp. 383-391.

Dean, R.A., K.R. Ferris and C. Konstans, 1988, Occupational reality shock and organizational commitment: Evidence from the accounting profession, Accounting, Organizations and Society 13 (3), pp. 235-250.

DeAngelo, L.E., 1981a, Auditor independence, 'low balling', and disclosure regulation, Journal of Accounting and Economics 3 (3), pp. 113-127.

DeAngelo, L.E., 1981b, Auditor size and audit quality, Journal of Accounting and Economics 3 (4), pp. 183-199.

DeAngelo, L.E., 1982, Mandated successful efforts and auditor choice, Journal of Accounting and Economics 4 (3), pp. 171-203.

DeFond, M.L., 1992, The association between changes in client firm agency costs and auditor switching, Auditing: A Journal of Practice \& Theory 11 (1), pp. 16-31.

DeFond, M.L. and C.W. Park, 1999, The effect of competition on CEO turnover, Journal of Accounting and Economics 27 (1), pp. 35-56.

Deis, D.R. and G.A. Giroux, 1992, Determinants of audit quality in the public sector, The Accounting Review 67 (3), pp. $462-479$.

Deppe, L.A., J.M. Smith and J.D. Stice, 1992, The debate over post-baccalaureate education: One university's experience, Issues in Accounting Education 7 (1), pp. 18-36.

Dillard, J.F., 1979, Valence-instrumentality-expectancy model validation using selected accounting groups, Accounting, Organizations and Society 4 (1/2), pp. $31-38$.

Dillard, J.F. and K.R. Ferris, 1979, Sources of professional staff turnover in public accounting firms: Some further evidence, Accounting, Organizations and Society 4 (3), pp. 179-186. 
Dillard, J.F. and K.R. Ferris, 1989, Individual behavior in professional accounting firms: A review and synthesis, Journal of Accounting Literature 8, pp. 208234.

Doeringer, P.B. and M.J. Piore, 1971, Internal labor markets and manpower analysis, Lexington: D.C. Heath.

Dopuch, N. and D. Simunic, 1980, The nature of competition in the accounting profession: A descriptive and normative view, In: J.W. Buckley, J.F. Weston (eds.), Regulation and the accounting profession, Belmont: Lifetime learning publications, pp. 77-94.

Doogar, R. and R.F. Easley, 1998, Concentration without differentiation: A new look at the determinants of audit market concentration, Journal of Accounting and Economics 25 (3), pp. 235-253.

Dunn, W.M. and T.W. Hall, 1984, An empirical analysis of the relationships between CPA examination candidate attributes and candidate performance, The Accounting Review 59(4), pp. 674-689.

Dunne, T., M.J. Roberts and L. Samuelson, 1988, Patterns of firm entry and exit in U.S. manufacturing industries, RAND Joumal of Economics 19 (4), pp. 495-515.

Eckard, E.W., 1987, Advertising, competition, and market share instability, Journal of Business 60 (4), pp. 539-552.

Eichenseher, J.W. and P. Danos, 1981, The analysis of industry-specific auditor concentration: Towards an explanatory model, The Accounting Review 56 (3), pp. 479-492.

Eichenseher, J.W., M. Hagigi and D. Shields, 1989, Market reactions to auditor changes by OTC companies, Auditing: A Journal of Practice \& Theory 9 (1), pp. 29-40.

Eichenseher, J.W. and D. Shields, 1985, Corporate director liability and monitoring preferences, Journal of Accounting and Public Policy 4 (1), pp. 13-31.

Elte, G.C., 1992, Bestaansrecht NIVRA-opleiding opnieuw ter discussie stellen: Voordracht tijdens NIVRA ledenvergadering 1991, De Accountant 99 (6), pp. 368-370.

Ettredge, M. and R. Greenberg, 1990, Determinants of fee cutting on initial audit engagements, Journal of Accounting Research 28 (1), pp. 198-210.

European Commission, 1996, The role, position, and liability of the statutory auditor within the European Union, Study commissioned by DG XV of the European Commission, Luxembourg: ECSC-EC-EAEC.

Fama, E.F. and M.C. Jensen, 1983, Agency problems and residual claims, Journal of Law and Economics 26 (2), pp. 327-349. 
Farber, H.S., 1994, The analysis of interfirm worker mobility, Joumal of Labor Economics 12 (4), pp. 554-593.

FEE (Fédération des Experts Comptables Européens), 1988, Training for the profession: A comparative study, Brussels: FEE.

Ferris, G.R., M.R. Buckley and G.M. Allen, 1992, Promotion systems in organizations, Human Resource Planning 15 (3), pp. 47-68.

Firth, M. 1985, An analysis of audit fees and their determinants in New Zealand, Auditing: A Journal of Practice \& Theory 4 (2), pp. 23-37.

Francis, J.R., 1984, The effect of audit firm size on audit prices: A study of the Australian market, Journal of Accounting and Economics 6 (2), pp. 133-151.

Francis, J.R. and D.J. Stokes, 1986, Audit prices, product differentiation, and scale economies: Further evidence from the Australian market, Journal of Accounting Research 24 (2), pp. 383-393.

Francis, J.R. and E.R. Wilson, 1988, Auditor changes: A joint test of theories relating to agency costs and auditor differentiation, The Accounting Review 63 (4), pp. 663-682.

Geroski, P.A. and J. Schwalbach (eds.), 1991, Entry and market contestability: An international comparison, Oxford: Basil Blackwell.

Gilling, D.M. and P.J. Stanton, 1978, Changes in the structure of the auditing profession in Australia, Abacus 14 (1), pp. 66-79.

Gilson, R.J. and R.H. Mnookin, 1985, Sharing among the human capitalists: An economic inquiry into the corporate law firm and how partners split profits, Stanford Law Review 37 (1), pp. 313-392.

Gilson, R.J. and R.H. Mnookin, 1989, Coming of age in a corporate law firm: The economics of associate career patterns, Stanford Law Review 41 (2), pp. $567-595$.

Gort, M., 1963, Analysis of stability and change in market shares, Journal of Political Economy 71 (1), pp. 51-63.

Gregson, T., 1990, Communication satisfaction: A path analytic study of accountants affiliated with CPA firms, Behavioral Research in Accounting 2, pp. 32-49.

Gregson, T., 1992, An investigation of the causal ordering of job satisfaction and organizational commitment in turnover models in accounting, Behavioral Research in Accounting 4, pp. 80-95.

Greve, H.R., 1994, Industry diversity effects on job mobility, Acta Sociologica 37 (2), pp. 119-139.

Hannan, M.T., 1997, Inertia, density and the structure of organizational populations: Entries in European automobile industries, 1886-1981, Organization Studies 18 (2), pp. 193-228. 
Hannan, M.T. and G.R. Carroll, 1992, Dynamics of organizational populations: Density, legitimation, and competition, Oxford: Oxford University Press.

Harrell, A., 1990, A longitudinal examination of large CPA firm auditors' personnel turnover, Advances in Accounting 8, pp. 233-246.

Harrell, A., E. Chewning and M. Taylor, 1986, Organizational-professional conflict and the job satisfaction and turnover intentions of internal auditors, Auditing: A Journal of Practice and Theory 5 (2), pp. 109-121.

Hashimoto, M., 1981, Firm-specific human capital as a shared investment, The American Economic Review 71 (3), pp. 475-482.

Haveman, H.A., 1995, The demographic metabolism of organizations: Industry dynamics, turnover, and tenure distributions, Administrative Science Quarterly 40 (4), pp. 586m618.

Hellriegel, D. and G.E. White, 1973, Turnover of professionals in public accounting: A comparative analysis, Personnel Psychology 26, pp. 239249.

Holmes, S. and I. Zimmer, 1998, The structure of profit sharing schemes in accounting partnerships, Accounting and Finance 38 (1), pp. 51-70.

Hooks, K.L., 1992, Gender effects and labor supply in public accounting: An agenda of research issues, Accounting, Organizations and Society 17 (3/4), pp. 343-366.

Hunton, J.E. and B. Wier, 1996, Performance of accountants in private industry: A survival analysis, Accounting Horizons 10 (3), pp. 54-77.

Hymer, S. and P. Pashigian, 1962, Turnover of firms as a measure of market behavior, The Review of Economics and Statistics 44 (1), pp. 82-87.

Idson, T.L., 1989, Establishment size differentials in internal mobility, The Review of Economics and Statistics 71 (4), pp. 721-724.

International Accounting Bulletin, 1993a, KPMG restructures command in major overhaul of US firm, International Accounting Bulletin (117), p. 1.

International Accounting Bulletin, 1993b, To change or not to change, International Accounting Bulletin (131), p. 4-5.

Iyer, V.M. and G.S. Iyer, 1996, Effect of big 8 mergers on audit fees: Evidence from the United Kingdom, Auditing: A Journal of Practice \& Theory 15 (2), pp. 123-132.

Jensen, M.C. and W.H. Meckling, 1976, Theory of the firm: Managerial behavior, agency costs and ownership structure, Joumal of Financial Economics 3 (4), pp. 305-360.

Jiambalvo, J., 1979, Performance evaluation and directed job effort: Model development and analysis in a CP.A firm setting, Journal of Accounting Research 17 (2), pp. 436-455. 
Johnson, E.N., K.B. Walker and E. Westergaard, 1995, Supplier concentration and pricing of audit services in New Zealand, Auditing: A Journal of Practice d Theory 14 (2), pp. 74-89.

Johnson, W.B. and T. Lys, 1990, The market for audit services: Evidence from voluntary auditor changes, Journal of Accounting and Economics 12 (1-3), pp. 281-308.

Jovanovic, B., 1979a, Job matching and the theory of turnover, Joumal of Political Economy 87 (5), pp. 972-990.

Jovanovic, B., 1979b, Firm-specific capital and turnover, Journal of Political Economy 87 (6), pp. 1246-1260.

Koninklijk Nederlands Instituut van Registeraccountants, 1980, De kennis van de bedrijfseconomie waarover de accountant zou moeten beschikken, Studierapport Commissie van Advies inzake Organisatievraagstukken, Amsterdam: Koninklijk Nederlands Instituut van Registeraccountants.

Koninklijk Nederlands Instituut van Registeraccountants, 1995, Requirements for qualification as a registeraccountant in the Netherlands, Pilot 17, Amsterdam: Koninklijk Nederlands Instituut van Registeraccountants.

Lachman, R. and N. Aranya, 1986, Job attitudes and turnover intentions among professionals in different work settings, Organization Studies 7 (3), pp. 279-293.

Langendijk, H.P.A.J., 1988, Verslaggeving door accountantskantoren, Research Memorandum 8817, Amsterdam: University of Amsterdam.

Langendijk, H.P.A.J. and H.J. Deetman, 1990, Concentratie op de markt voor accountantscontrole in Nederland, In: C. Knoops, J. Dijksma and W.M. du Pon (eds.), FMA-kroniek, Groningen: Wolters-Noordhoff, pp. 377-394.

Larkin, J.M., 1997, Upward mobility in public accounting: A gender-specific student perspective, Journal of Applied Business Research 13 (2), pp. 109 119.

Lawler, E.E. III, W.J. Kuleck Jr., J.G. Rhode and J.E. Sorensen, 1975, Job choice and post decision dissonance, Organizational Behavior and Human Performance 13 (2), pp. 133-145.

Lazear, E.P., 1998, Personnel economics for managers, New York: John Wiley \& Sons.

Lazear, E.P. and S. Rosen, 1981, Rank-order tournaments as optimum labor contracts, Journal of Political Economy 89 (5), pp. 841-864.

Leathers, P.E., 1970, The staff retention problem in public accounting: Background and questions for discussion, Subcommittee on Staff Retention of the Committee on Education, New York: American Institute of Certified Public Accountants. 
Lee, D.S., 1994, Further evidence on auditor concentration: The case of a growing market, The International Journal of Accounting 29 (3), pp. 234-250.

Levinthall, D.A. and M. Fichman, 1988, Dynamics of interorganizational attachments: Auditor-client relationships, Administrative Science Quarterly 33 (3), pp. 345-369.

Maijoor, S.J., W.F.J. Buijink, A. van Witteloostuijn and M.W.H. Zinken, 1995, Long-term concentration in the Dutch audit market: The use of auditor association membership lists in historical research, Abacus 31 (2), pp. 152177.

Maijoor, S.J. and A. van Witteloostuijn, 1996, An empirical test of the resourcebased theory: Strategic regulation in the Dutch audit industry, Strategic Management Journal 17 (7), pp. 549-569.

Malos, S.B. and M.A. Campion, 1995, An options-based model of career mobility in professional service firms, Academy of Management Review 20 (3), pp. 611-644.

Marten, K-U., 1996, Developments in concentration on the German audit market, Working paper, Augsburg: Universität Augsburg.

Maupin, R.J. and C.R. Lehman, 1994, Talking heads: Stereotypes, status, sexroles, and satisfaction of female and male auditors, Accounting, Organizations and Society 19 (4/5), pp. 427-437.

Mautz, R.K. and H.A. Sharaf, 1961, The philosophy of auditing, Sarasota: American Accounting Association.

McCormick, E.J. and D.R. Ilgen, 1980, Industrial psychology, Seventh edition, Englewood Cliffs: Prentice Hall.

Menon, K. and D.D. Williams, 1991, Auditor credibility and initial public offerings, The Accounting Review 66 (2), pp. 313-332.

Meuwissen, R.H.G., 1992, De meting van de omvang van accountantskantoren: Een empirische studie, MARC Research Memorandum 92/016, Maastricht: Rijksuniversiteit Limburg.

Meuwissen, R.H.G., 1998, Career advancement in audit firms: An empirical study of university-educated and non university-educated Dutch auditors, Accounting Education 7 (1), pp. 35-50.

Meuwissen, R.H.G. and S.J. Maijoor, 1997, Audit markets in the European Union: Regulation in Belgium, Germany and the Netherlands, In: M. Sherer and S. Turley (eds.), Current Issues in Auditing, third edition, London: Paul Chapman Publishing, pp. 146-162.

Mincer, J., 1974, Schooling, experience, and earnings, New York: Columbia University Press. 
Mobley, W.H., R.W. Griffeth, H.H. Hand and B.M. Meglino, 1979, Review and conceptual analysis of the employee turnover process, Psychological Bulletin 86 (3), pp. 493-522.

Mock, T.J. and J.L. Tumer, 1981, Internal accounting control evaluation and auditor judgment, Auditing monograph no. 3, New York: AICPA.

Moizer, P. and S. Turley, 1987, Surrogates for audit fees in concentration studies, Auditing: A Journal of Practice \& Theory 7 (1), pp. 118-123.

Moizer, P. and S. Turley, 1989, Changes in the UK market for audit services: 1972-1982, Journal of Business Finance \& Accounting 16 (1), pp. 41-53.

Moriarty, J., 1993, A divided profession, European Accountant 10 (3), pp. 12-14.

Morita, J.G., T.W. Lee and R.T. Mowday, 1989, Introducing survival analysis to organizational researchers: A selected application to turnover research, Journal of Applied Psychology 74 (2), pp. 280-292.

Morita, J.G., T.W. Lee and R.T. Mowday, 1993, The regression-analog to survival analysis: A selected application to turnover research, Academy of Management Journal 36 (6), pp. 1430-1464.

Morse, D., 1993, Explaining the international supply of auditors, The International Joumal of Accounting 28 (4), pp. 347-355.

Mueller, D., 1991, Entry, exit, and the competitive process, In: P.A. Geroski and J. Schwalbach (eds.), Entry and market contestability: An international comparison, Oxford: Basil Blackwell, pp. 1-22.

NERA (National Economic Research Associates), 1992, Competition in European accounting, Dublin: Lafferty Publications.

Nobes, C. and R. Parker, 1998, Comparative international accounting, Fifth edition, Hemel Hempstead: Prentice Hall Europe.

Norris, D.R. and R.E. Niebuhr, 1983, Professionalism, organizational commitment and job satisfaction in an accounting organization, Accounting, Organizations and Society 9 (1), pp. $49-59$.

Nystrom, P.C. and A.W. McArthur, 1989, Propositions linking organizations and careers, In: M.B. Arthur, D.T. Hall and B.S. Lawrence (eds.), Handbook of career theory, Cambridge: Cambridge University Press, pp. 490-505.

O'Flaherty, B. and A. Siow, 1995, Up-or-out rules in the market for lawyers, Journal of Labor Economics 13 (4), pp. 709-735.

O'Keefe, T.B., D.A. Simunic and M.T. Stein, 1994, The production of audit services: Evidence from a major public accounting furm, Journal of Accounting Research 32 (2), pp. 241-261.

Palmrose, Z.V., 1986, Auditor fees and auditor size: Further evidence, Journal of Accounting Research 24 (1), pp. 97-110. 
Palmrose, Z.V., 1987, Litigation and independent auditors: The role of business failures and management fraud, Auditing: A Journal of Practice \& Theory 6 (2), pp. 90-103.

Palmrose, Z.V., 1988, An analysis of auditor litigation and audit service quality, The Accounting Review 63 (1), pp. 55-73.

Pearson, T. and G. Trompeter, 1994, Competition in the market for audit services: The effect of supplier concentration on audit fees, Contemporary Accounting Research 11 (1-1), pp. 115-135.

Peel, M.J., 1997, UK auditor concentration: A descriptive note, Accounting and Business Research 27 (4), pp. 311-322.

Petersen, T., 1991, The statistical analysis of event histories, Sociological Methods \& Research 19 (3), pp. 270-323.

Petersen, T. and K.W. Koput, 1992, Time-aggregation bias in hazard-rate models with covariates, Sociological Methods \& Research 21 (1), pp. 25-51.

Pillsbury, C.M., L. Capozzoli and A. Ciampa, 1989, A synthesis of research studies regarding upward mobility of women in public accounting, Accounting Horizons 3 (1), pp. 63-70.

Quarles, R., 1994, An examination of promotion opportunities and evaluation criteria as mechanisms for affecting internal auditor commitment, job satisfaction and turnover intentions, Journal of Managerial Issues $6(2)$, pp. 176-194.

Quick, R., M. Wolz and M. Seelbach, 1998, Die Struktur des Prüfungsmarktes für deutsche Aktiengesellschaften: Eine empirische Untersuchung der Konzentration auf dem deutschen Wirtschaftsprüfungsmarkt für Aktiengesellischaften, Zeitschrift fur Betriebswirtschaft 68 (8), pp. 779-802.

Reed, S.A., S.H. Kratchman, and R.H. Strawser, 1994, Job satisfaction, organizational commitment, and turnover intentions of United States accountants: The impact of locus of control and gender, Accounting, Auditing \& Accountability Journal 7 (1), pp. 31-58.

Rhode, J.G., J.E. Sorensen and E.E. Lawler III, 1976, An analysis of personal characteristics related to professional staff turnover in public accounting firms, Decision Sciences 7 (4), pp. $771-800$.

Rhode, J.G., J.E. Sorensen and E.E. Lawler III, 1977, Sources of professional staff turnover in public accounting firms revealed by the exit interview, Accounting, Organizations and Saciety 2 (2), pp. 165-175.

Rhode, J.G., G.M. Whitsell and R.L. Kelsey, 1974, An analysis of client-industry concentrations for large public accounting firms, The Accounting Review 49 (4), pp. 772-787. 
Rosenbaum, J.A., 1984, Career mobility in a corporate hierarchy, Orlando: Academic Press.

Rosenfeld, R.A., 1992, Job mobility and career processes, Anmual Review of Sociology 18, pp. 39-61.

Sandler, R.D., 1988, Market share instability in commercial airline markets and the impact of deregulation, The Journal of Industrial Economics 36 (3), pp. 327-335.

Schiff, A. and H.D. Fried, 1976, Large companies and the big eight: An overview, Abacus 12 (2), pp. 116-124.

Schmalensee, R., 1982, The new industrial organization and the economic analysis of modern markets, In: W. Hildenbrand (ed.), Advances in economic theory, Cambridge: Cambridge University Press, pp. 253-285.

Schmalensee, R., 1989, Inter-industry studies of structure and performance, In: R. Schmalensee and R.D. Willig (eds.), Handbook of industrial organization, Volume II, Amsterdam: Elsevier Science Publishers, pp. 951-1009.

Senatra, P.T., 1980, Role conflict, role ambiguity, and organizational climate in a public accounting firm, The Accounting Review 55 (4), pp. 594-603.

Shaw, K.L., 1987, Occupational change, employer change, and the transferability of skills, Southern Economic Journal 53 (3), pp. 702-719.

Sheridan, J.E., 1992, Organizational culture and employee retention, Academy of Management Journal 35 (5), pp.1036-1056.

Shorrocks, A.F., 1978, The measurement of mobility, Econometrica 46 (5), pp. 1013-1024.

Sicherman, N. and O. Galor, 1990, A theory of career mobility, Journal of Political Economy 98 (1), pp. 169-192.

Siegel, P.H., 1987, Auditor performance and educational preparation: An analysis, Issues in Accounting Education 2 (1), pp. 127-140.

Siegel, P.H., M.M. Blank and J.T. Rigsby, 1991, Socialisation of the accounting professional: Evidence of the effect of educational structure on subsequent auditor retention and advancement, Accounting, Auditing \& Accoumiability Journal 4 (4), pp. 58-70.

Siegel, P.H. and J.T. Rigsby, 1988, The relationship of accounting internships and subsequent professional performance, Issues in Accounting Education 3 (2), pp. 423-432.

Siegel, P.H., J.T. Rigsby and J. Leavins, 1992, An analysis of the relative contribution of experience/education to the professional development of auditors, Advances in Accounting 10, pp. 143-158.

Siegel, S. and N.J. Castellan Jr., 1988, Nonparametric statistics for the behavioral sciences, Second edition, Singapore: McGraw-Hill. 
Simon, D.T., 1985, The audit services market: Additional empirical evidence, Auditing: A Journal of Practice \& Theory 5 (1), pp. 71-78.

Simon, D.T. and J.R. Francis, 1988, The effects of auditor change on audit fees: Tests of price cutting and price recovery, The Accounting Review 63 (2), pp. 255-269.

Simunic, D.A., 1980, The pricing of audit services: Theory and evidence, Journal of Accounting Research 18 (1), pp. 161-190.

Simunic, D.A., 1984, Auditing, consulting, and auditor independence, Journal of Accounting Research 22 (2), pp. 679-702.

Simunic, D.A. and M.T. Stein, 1987, Product differentiation in auditing: Auditor choice in the market for unseasoned new issues, Research monograph no. 13, Vancouver: The Canadian Certified General Accountants' Research Foundation.

Simunic, D.A. and M.T. Stein, 1996, The impact of litigation risk on audit pricing: A review of the economics and the evidence, Auditing: A Journal of Practice \& Theory 15 (supplement), pp. 119-134.

Smith, D.R., 1983, Mobility in professional occupational-internal labor markets: Stratification, segmentation, and vacancy chains, American Sociological Review 48 (3), pp. 289-305.

Snead, K. and A. Harrell, 1991, The impact of psychological factors on the job satisfaction of senior auditors, Behavioral Research in Accounting 3, pp. 85-96.

Sorensen, J.E., J.G. Rhode and E.E. Lawler III, 1973, The generation gap in public accounting, Journal of Accountancy 136 (6), pp. 42-50.

Spiceland, J.D., P.H. Siegel and C.R. George, 1992, Educational preparation of auditors, promotion time, and turnover: A survival analysis, Advances in Accounting 10, pp. 61-76.

Spurr, S.J. and G.T. Sueyoshi, 1994, Turnover and promotion of lawyers: An inquiry into gender differences, The Journal of Human Resources 29 (3), pp. 813-842.

Steel, R.P. and N.K. Ovalle, 1984, A review and meta-analysis of research on the relationship between behavioral intentions and employee turnover, Journal of Applied Psychology 69 (4), pp. 673-686.

Stewman, S. and S.L. Konda, 1983, Careers and organizational labor markets: Demographic models of organizational behavior, American Journal of Saciology 88 (4), pp. 637-685.

St.Pierre, K. and J.A. Anderson, 1984, An analysis of the factors associated with lawsuits against public accountants, The Accounting Review 59 (2), pp. $242-263$. 
Tett, R.P. and J.P. Meyer, 1993, Job satisfaction, organizational commitment, turnover intention, and turnover: Path analyses based on meta-analytic findings, Personnel Psychology 46 (2), pp. 259-293.

Tomczyk, S. and W.J. Read, 1989, Direct measurement of supplier concentration in the market for audit services, Auditing: A Journal of Practice \& Theory 9 (1), pp. 98-106.

Tonge, S.D. and C.W. Wootton, 1991, Auditor concentration and competition among the large public accounting firms: Post-merger status and future implications, Journal of Accounting and Public Policy 10 (2), pp. 157-172.

Topel, R.H. and M.P. Ward, 1992, Job mobility and the careers of young men, Quarterly Journal of Economics 107 (2), pp. 439-479.

Turpen, R.A., 1990, Differential pricing on auditors' initial engagements: Further evidence, Auditing: A Journal of Practice \& Theory 9 (2), pp. 60-76.

Vardi, Y., 1980, Organizational career mobility: An integrative model, Academy of Management Journal 5 (3), pp. 341-355.

Wallace, W.A., 1987, The economic role of the audit in free and regulated markets: A review, Research in Accounting Regulation 1, pp. 7-34.

Wallace, W.A., 1991, Auditing, Second edition, Boston: PWS-Kent Publishing Company.

Waller, W.S., 1985, Self-selection and the probability of quitting: A contracting approach to employee turnover in public accounting, Journal of Accounting Research 23 (2), pp. 817-828.

Watts, R.L. and J.L. Zimmerman, 1983, Agency problems, auditing and the theory of the firm: Some evidence, Journal of Law and Economics 26 (3), pp. 613634.

Watts, R.L. and J.L. Zimmerman, 1986, Positive accounting theory, Englewood Cliffs: Prentice-Hall.

Weets, V. and M. Jegers, 1997, Are the 'big six" 'big' in Belgium, European Accounting Review 6 (4), pp. 773-789.

Weiss, L.W. (Ed.), 1989, Concentration and price, Boston: MIT Press.

Wholey, D.R., 1985, Determinants of firm internal labor markets in large law firms, Administrative Science Quarterly 30 (3), pp. 318-335.

Wright, A., 1988, The comparative performance of MBA's vs. undergraduate accounting majors in public accounting, The Accounting Review 63 (1), pp" $123-136$.

Yardley, J.A., N.L. Kaufiman, T.D. Cairney and W.D. Albrecht, 1992, Supplier behavior in the U.S. audit market, Journal of Accounting Literature 11, pp. $151-184$. 
Zeff, S.A. and R.L. Fossum, 1967, An analysis of large audit clients, The Accounting Review 42 (2), pp. 298-320.

Zeff, S.A., F. van der Wel and K. Camfferman, 1992, Company financial reporting: A historical and comparative study of the Dutch regulatory process, Amsterdam: Elsevier Science Publishers.

Zind, R.G. and D. Zéghal, 1989, Some characteristics of the Canadian audit industry, Contemporary Accounting Research 6 (1), pp. 26-47. 


\section{Summary in Dutch (Nederlandse samenvatting)}

\section{The economics of auditor careers and audit markets}

(Een economische analyse van carrières van accountants en van de markt voor accountantscontrole)

Dit proefschrift presenteert een economische analyse van carrières van individuele accountants en van de markt voor accountantscontrole. Hiertoe zijn drie empirische studies verricht. Carrières van accountants worden onderzocht door middel van een studie naar de carrière-voortgang van accountants binnen accountantskantoren, alsmede door middel van een studie naar de mobiliteit van accountants tussen verschillende werkgevers. De analyse van de markt voor accountantscontrole heeft betrekking op een studie naar de structuur van de accountantsmarkt in drie landen (België, Duitsland en Nederland).

Het doel van dit onderzoek is tweeledig. (1) Ten aanzien van carrières van accountants tracht dit proefschrift een bijdrage te leveren aan de empirische literatuur door accountantskantoren te benaderen als verzamelingen van individuele accountants in plaats van als zelfstandige organisaties. Zodoende is het mogelijk om vraagstukken ten aanzien van de productie van accountantsdiensten, zoals het effect van cliënt-specifieke investeringen of het bestaan van kwaliteitsverschillen tussen accountantskantoren, te benaderen vanuit de optiek van de individuele accountant. (2) Ten aanzien van de markt voor accountantscontrole tracht dit proefschrift een bijdrage te leveren aan het meten van concurrentie op die markt door het introduceren van een dynamische analyse van marktstructuur.

Dit proefschrift omvat dus zowel onderzoek naar individuele carrières als naar concurrentie op de markt voor accountantscontrole. Aangezien menselijk kapitaal de belangrijkste productiefactor is bij de accountantscontrole, zijn beide onderwerpen nauw gerelateerd. De capaciteit van een kantoor om controles te verrichten wordt gevormd door de gezamenlijke capaciteit van de individuele 
accountants [vgl. Gilson en Mnookin (1985)]. Indien accountants van werkgever veranderen nemen zij dus een deel van de capaciteit van het accountantskantoor mee. Dit beinvloedt de concurrentiepositie van het kantoor op twee manieren. Enerzijds gaat een deel van de productiecapaciteit verloren. Anderzijds kunnen accountants die het kantoor verlaten eenvoudig hun eigen kantoor oprichten en daarmee een concurrent worden van hun vroegere werkgever. De dynamiek in de accountantsmarkt wordt dus voor een deel bepaald door carrière-beslissingen van individuele accountants. Hierdoor is de markt waar accountantskantoren diensten leveren aan cliënten (product markt) nauw verbonden met de markt waar men arbeidskrachten werft (factor markt).

Deze interactie tussen de product markt en de factor markt is in hoofdstuk 1 gebruikt als basis voor een beknopt overzicht van de empirische onderzoeksliteratuur op het gebied van accountantscontrole. Aangezien dit proefschrift een economische benadering hanteert wordt slechts economisch getint onderzoek besproken. Geconstateerd wordt dat vanuit dit oogpunt weinig onderzoek is verricht naar carrières van individuele accountants. Zodoende bevat hoofdstuk 2 een onderzoek naar de carrière-voortgang van accountants binnen accountantskantoren en onderzoekt hoofdstuk 3 de mobiliteit van accountants tussen verschillende werkgevers. Voorts blijkt dat bestaande studies over de markt voor accountantscontrole slechts een statische analyse hebben gehanteerd in plaats van een in de industriële organisatie literatuur gebruikelijke dynamische analyse. Hoofdstuk 4 beschrijft een onderzoek naar de dynamiek van de accountantsmarkt in drie landen. Deze drie empirische studies worden navolgend besproken.

In hoofdstuk 2 wordt de studie naar de carrière-voortgang van accountants binnen accountantskantoren besproken. Deze studie analyseert de invloed van een viertal factoren op de carrière-voortgang van accountants. Carrière-voortgang wordt gemeten aan de hand van twee criteria: het al dan niet bereiken van de positie van partner in een accountantskantoor en de snelheid waarmee deze positie bereikt wordt. Als verklarende variabelen voor carrière-voortgang worden opleiding, leeftijd op het tijdstip waarop men accountant wordt (als benadering voor studieduur), omvang van het accountantskantoor en het tussentijds veranderen van accountantskantoor gehanteerd. De gegevens over de carrières van accountants zijn verkregen aan de hand van ledenlijsten van het Koninklijk Nederlands Instituut van Registeraccountants (NIVRA). Deze ledenlijsten worden (twee)jaarlijks gepubliceerd en bevatten van iedere registeraccountant de werkgever en functie. De carrières van accountants worden geanalyseerd van 1970 tot 1998. 
Uit voorgaand onderzoek blijkt dat opleiding een belangrijke variabele is bij het verklaren van carrière-voortgang bij accountants. Echter, dit onderzoek is verricht in de Verenigde Staten waar slechts het onderscheid bestaat tussen een driejarige en een vierjarige academische opleiding tot accountant. Zodoende is dit onderzoek slechts beperkt gebleven tot het meten van het effect van een additioneel jaar academische studie. Nederland biedt in dit geval een unieke mogelijkheid tot het vergelijken van de effecten van een academische opleiding en een praktijkopleiding (NIVRA-opleiding). De resultaten van deze vergelijking tonen aan dat academisch opgeleide accountants een grotere kans hebben om partner te worden van een accountantskantoor en dat zij bovendien sneller partner worden dan niet-academisch opgeleide accountants. Een multivariate analyse toont verder aan dat een langere studieduur de kansen op een partnerschap verlaagt, ongeacht de aard van de opleiding. Hieruit kan worden afgeleid dat de betere carrière-perspectieven van academisch opgeleide accountants niet het gevolg zijn van de aard van de opleiding, maar van de jongere leeftijd waarop zij registeraccountant worden.

Ten aanzien van de andere verklarende variabelen wordt geconcludeerd dat de omvang van het accountantskantoor en het tussentijds veranderen van accountantskantoor negatief zijn gerelateerd aan carrière-voortgang van accountants. Bovendien wordt geconcludeerd dat accountants die de accountantsopleiding relatief snel hebben doorlopen daardoor niet sneller partner worden.

Tenslotte wordt geconcludeerd dat academisch opgeleide accountants vergeleken met niet-academisch opgeleide accountants sneller en vaker een accountantskantoor verlaten indien ze daar geen partner kunnen worden. Blijkbaar vergroot hun meer algemene opleiding de kans op een functie buiten het accountantsberoep.

Hoofdstuk 3 onderzoekt de mobiliteit van accountants tussen verschillende werkgevers. Een dergelijk onderzoek verschaft inzicht in de productie van accountantsdiensten, bijwoorbeeld ten aanzien van het effect van cliënt-specifieke investeringen, het bestaan van kwaliteitsverschillen tussen accountantskantoren en het hanteren van een up-or-out promotiesysteem. Cliënt-specifieke kennis, verkregen door specialisatie of het bedienen van een beperkt aantal grotere cliënten, is minder toepasbaar op andere cliënten. Hierdoor kunnen accountants optimaal functioneren bij cliënten waarvan ze cliënt-specifjeke kennis bezitten, maar zijn zij minder effectief bij andere cliënten. Ervan uitgaande dat accountants cliënten niet eenvoudig mee kunnen nemen indien zij veranderen van accountantskantoor, kan gesteld worden dat dergelijke kennis de mobiliteit van accountants verlaagt. In het geval van kwaliteitsverschillen tussen 
accountantskantoren zullen deze weerspiegeld worden in het mobiliteitspatroon van individuele accountants. Verwacht kan worden dat mobiliteit van kantoren met een hoge kwaliteit naar kantoren met een lage kwaliteit eenvoudiger zal verlopen dan omgekeerd. Wat betreft up-or-out promotiesystemen kan verwacht worden dat deze voornamelijk worden gebruikt door grotere accountantskantoren aangezien zij daartoe de schaalvoordelen bezitten. Accountants van grotere accountantskantoren zullen hierdoor ten tijde van de beslissing of ze wel of geen partner kunnen worden een grotere mobiliteit vertonen.

Om de mobiliteit van accountants te analyseren is de statistische techniek event history analysis gebruikt. Deze techniek is bij uitstek geschikt voor onderzoek naar mobiliteit aangezien zij de mogelijkheid biedt om het tijdstip waarop mobiliteit plaatsvindt in de analyse mee te nemen. Daarnaast biedt deze techniek de mogelijkheid om variabelen die gedurende een carrière veranderen in de analyse op te nemen. Evenals de studie naar de carrière-voortgang van accountants (hoofdstuk 2), zijn de gegevens over de mobiliteit van accountants verkregen aan de hand van ledenlijsten van het Koninklijk NIVRA en wordt de mobiliteit van accountants geanalyseerd van 1970 tot 1998 .

Allereerst is een model geschat van de mobiliteit van alle accountants. De resultaten tonen aan dat de mobiliteit in het begin van een arbeidsrelatie toeneemt en na drie jaar geleidelijk afneemt. Daarnaast laat deze analyse onder meer zien dat academische opgeleide accountants meer mobiliteit vertonen dan praktisch opgeleide accountants. De mobiliteit daalt sterk indien accountants een eigen kantoor hebben opgericht of indien ze partner zijn geworden in een accountantskantoor.

Vervolgens zijn specifieke vormen van mobiliteit onderzocht om de effecten van cliënt-specifieke investeringen, kwaliteitsverschillen tussen kantoren en het bestaan van up-or-out promotie systemen te testen. De bevindingen tonen aan dat, zoals verwacht kon worden op basis van de human capital-theorie, de mobiliteit daalt naarmate accountants meer cliënt-specifieke kennis bezitten. Als gevolg van een grotere specialisatie of meer cliënt-specifieke investeringen verminderen accountants zodoende hun mobiliteit.

Daarnaast geven de resultaten aan dat accountants wel overstappen van kantoren met een hoge kwaliteit naar accountantskantoren met een lagere kwaliteit, maar dat dit proces zich nauwelijks voltrekt in omgekeerde richting. Hieruit kan afgeleid worden dat kwaliteitsverschillen tussen accountantskantoren tevens tot uitdrukking komen in mobiliteitspatronen van individuele accountants.

Tenslotte wordt geconcludeerd dat up-or-out promotie systemen vaker worden gehanteerd door grote kantoren dan door kleine kantoren. Hierdoor ontstaat bij de grotere kantoren ten tijde van de partner beslissing (na een zeven- 
tot tien-jarige evaluatieperiode) een uitstroom van accountants die geen partner kunnen worden. Dit effect is niet zichtbaar bij kleinere accountantskantoren. Naar verwachting kunnen zij vanwege hun kleinere omvang minder gemakkelijk een dergelijk systeem hanteren.

Hoofdstuk 4 beschrijft een vergelijkend onderzoek naar de structuur van de markt voor accountantscontrole in België, Duitsland en Nederland. De accountantsmarkt wordt in deze drie landen onderzocht door middel van zowel een statische analyse als een dynamische analyse. Een statische analyse meet de concentratie op de markt op één moment in de tijd, terwijl een dynamische analyse kijkt naar verschillen in marktaandeel tussen twee perioden. Om verschillen in marktstructuur tussen de drie landen te kunnen verklaren wordt tevens de regelgeving op het gebied van accountantscontrole in deze landen geanalyseerd. Het aantal accountants per accountantskantoor is in deze studie als maatstaf gehanteerd om het aandeel van een kantoor in de markt te meten. Deze gegevens zijn afkomstig van ledenlijsten van het Instituut der Bedrijfsrevisoren in België, de Wirtschaftsprüferkammer in Duitsland en het Koninklijk NIVRA in Nederland. De analyse heeft betrekking op de periode 1970 tot 1994.

Op basis van een vergelijking van regelgeving zal de Nederlandse markt voor accountantscontrole naar verwachting het meest competitief zijn. Vergeleken met de Belgische en Duitse regelgeving op het gebied van accountantscontrole zijn er in Nederland minder stringente toelatingseisen tot het beroep, is reclame toegestaan, is er geen minimale periode waarin cliënten niet van accountant mogen wisselen en zijn er geen restricties bij het vaststellen van de prijs voor een accountantscontrole. De Belgische en Duitse markt voor accountantscontrole hebben in vergelijking met elkaar een ongeveer even strikte regelgeving.

De analyse van de structuur van de markt voor accountantscontrole in Belgie, Duitsland en Nederland laat zien dat de minder sterk gereguleerde Nederlandse markt de hoogste dynamiek vertoont maar tevens de hoogste (statische) concentratiegraad heeft. Hieruit kan worden afgeleid dat een hoge concentratiegraad niet automatisch betekent dat de markt minder competitief is. Immers, de Nederlandse markt heeft tevens de grootste verschuivingen in marktaandeel over tijd. Zodoende wordt geconcludeerd dat een dynamische analyse van de structuur van de markt voor accountantscontrole een beter beeld geeft van de mate van competitie in accountantsmarkten dan de tot nu toe gehanteerde statische analyse.

Tenslotte bevat hoofdstuk 5 een samenvatting van dit proefschrift en een reflectie op de verrichte studies. Deze reflectie bevat een bespreking van de relatieve 
sterkten en zwakten van het onderzoek. Tevens worden de praktische implicaties van de conclusies van dit proefschrift besproken. Zo kan bijvoorbeeld de huidige trend tot meer industrie-specialisatie binnen accountantskantoren leiden tot minder mobiele accountants. Bovendien kan informatie over de timing van mobiliteit van accountants werkgevers inzicht geven in hoe lang accountants behouden blijven voor de organisatie. Daarnaast geeft de analyse van de markt voor accountantscontrole aan dat regulerende instanties, zoals de Europese Commissie, competitie in de accountantsmarkt moeten beoordelen op basis van een dynamische analyse. Tenslotte worden enkele aanbevelingen gedaan voor verder onderzoek naar carrières van accountants en de markt voor accountantscontrole. 


\section{Curriculum Vitae}

Roger H.G. Meuwissen was born on June 10, 1967 in Sittard. From 1987 to 1992 he studied Business Administration at University Maastricht. During his studies he worked as a research-assistant at the Department of Accounting. In 1992 he became a researcher at the Mastricht Accounting and Auditing Research and Education Center (MARC). During 1993-1994, he followed the post-graduate auditing programme at University Maastricht, and qualified as a registered accountant. Since December 1996 he has been working as assistant professor in Control and Auditing at the Accounting and Auditing Section. Currently, he is also a member of the Editorial Board of Accounting Education.

Roger H.G. Meuwissen werd op 10 juni 1967 geboren te Sittard. In 1987 behaalde hij zijn Atheneum diploma aan de Albert Schweitzer Scholengemeenschap te Geleen. Van 1987 tot 1992 studeerde hij Bedrijfseconomie aan de Universiteit Maastricht. Tijdens zijn studie was hij gedurende twee jaar student-assistent bij de sectie Berichtgeving. In 1992 trad hij als onderzoeker in dienst bij het Mastricht Accounting and Auditing Research and Education Center (MARC). Daarnaast studeerde hij van 1993 tot 1994 aan de Postdoctorale Accountantsopleiding van de Universiteit Maastricht, waar hij in 1994 zijn registeraccountant-diploma behaalde. Vanaf december 1996 werkt hij als universitair docent Control en Auditing bij de sectie Accounting en Auditing. Tevens is hij sinds 1998 lid van de Editorial Board van het tijdschrift Accounting Education. 